Cíntia Luiza da Silva Luz
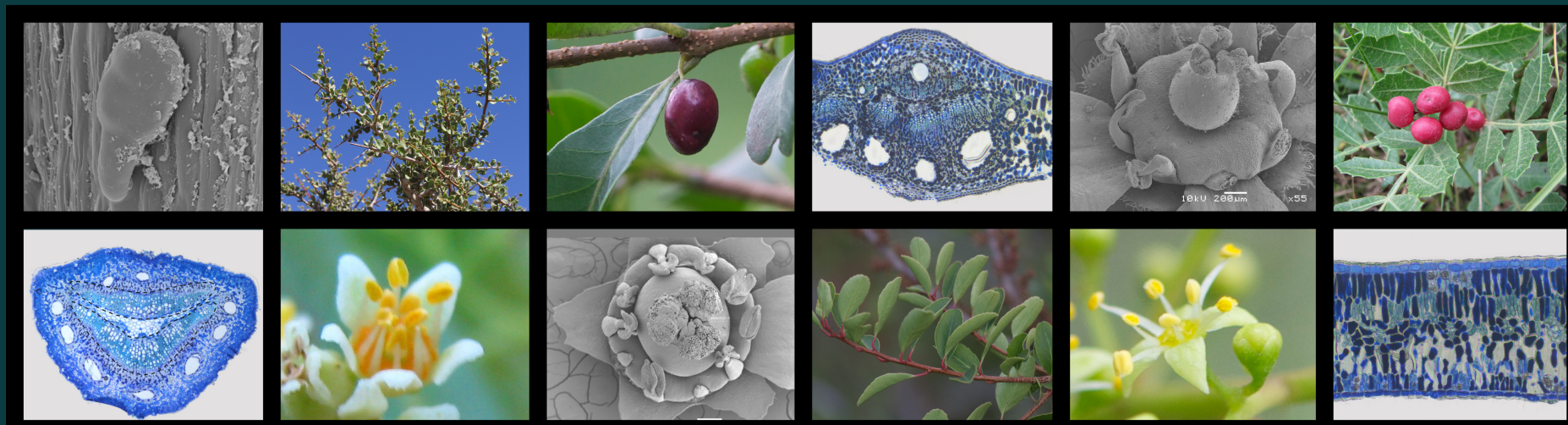

\title{
Filogenia e sistemática de Schinus L. (Anacardiaceae), COM REVISÃO DE UM CLADO ENDÊMICO DAS MATAS NEBULARES ANDINAS
}
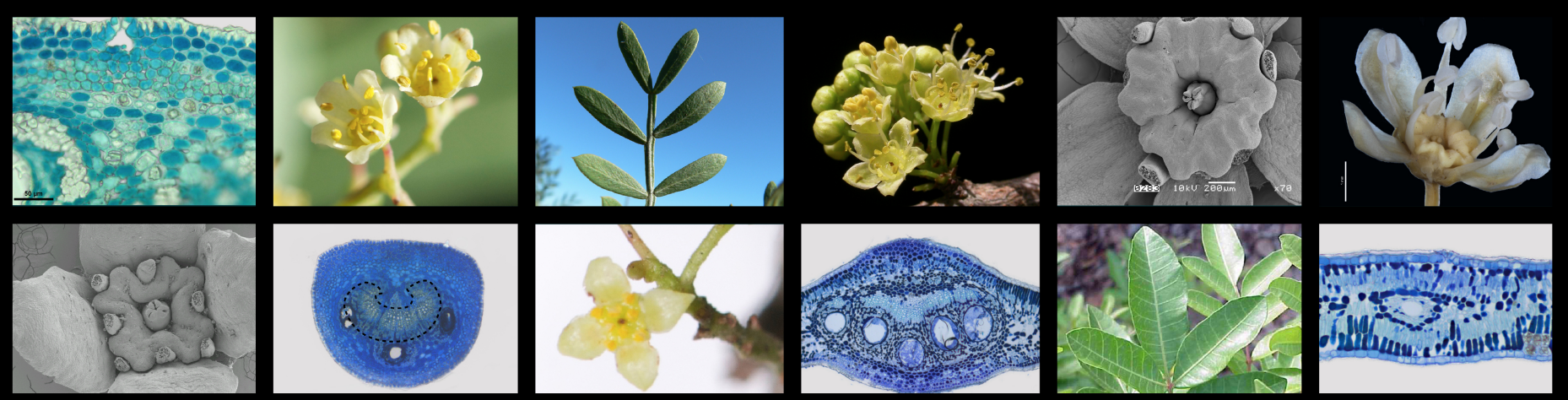
Cíntia Luíza da Silva Luz

Filogenia e sistemática de Schinus L. (Anacardiaceae), com revisão de um clado endêmico das matas nebulares andinas

Phylogeny and systematics of Schinus L. (Anacardiaceae), with revision of a clade endemic to the Andean cloud forests

Tese apresentada ao Instituto de Biociências da Universidade de São Paulo, para obtenção de Título de Doutor em Ciências, na Área de Botânica.

Orientador: Dr. José Rubens Pirani 
Luz, Cíntia Luíza da Silva

Filogenia e sistemática de Schinus L. (Anacardiaceae), com revisão de um clado endêmico das matas nebulares andinas

Número de páginas: 176

Tese (Doutorado) - Instituto de Biociências da Universidade de São Paulo. Departamento de Botânica.

1. Anacardiaceae 2. Schinus 3. Filogenia 4. Taxonomia vegetal I. Universidade de São Paulo. Instituto de Biociências. Departamento de Botânica

\section{Comissão julgadora:}

$\operatorname{Prof}(\mathrm{a})$. Dr.(a)

$\operatorname{Prof}(\mathrm{a})$. Dr.(a)

$\operatorname{Prof}(\mathrm{a}) . \operatorname{Dr} .(\mathrm{a})$

$\operatorname{Prof}(\mathrm{a})$. Dr.(a)

Prof. Dr. José Rubens Pirani

Orientador 
Ao Luciano Luz, pelo entusiasmo botânico, companheirismo e dedicação aos Schinus 
Esta é a estória. la um menino, com os tios, passar dias no lugar onde se construía a grande cidade. Era uma viagem inventada no feliz; para ele, produzia-se em caso de sonho. Saíam ainda com o escuro, o ar fino de cheiros desconhecidos. A mãe e o pai vinham trazê-lo ao aeroporto. A tia e o tio tomavam conta dele, justínhamente. Sorria-se, saudava-se, todos se ouviam e falavam. $O$ avião era da companhia, especial, de quatro lugares. Respondiam-lhe a todas as perguntas, até o piloto conversou com ele. $O$ vôo ia ser pouco mais de duas horas. O menino fremla no acorçôo, alegre de se rir para si, confortavelzinho, com um jeito de folha a cair. A vida podia às vezes raiar numa verdade extraordinária. Mesmo o afivelaremIhe o cinto de segurança virava forte afago, de proteção, e logo novo senso de esperança: ao não-sabido, ao mais. Assim um crescer e desconter-se - certo como o ato de respirar - o de fugir para o espaço em branco. 0 menino. 


\section{Agradecimentos}

Ao professor Dr. José Rubens Pirani, pelo apoio, confiança e orientação que contribuíram para a realização deste trabalho e da minha formação botânica.

À Fundação de Amparo à Pesquisa do Estado de São Paulo (FAPESP processos 2013/04345-2, 2014/18490-7), pela concessão da bolsa de doutorado e bolsa estágio de pesquisa no exterior (BEPE), a qual permitiu a realização de parte deste projeto no Jardim Botânico de Nova lorque, EUA. Ambas as bolsas foram essenciais para o desenvolvimento do projeto de doutorado e para a minha formação profissional. Além disso, pelo projeto de pesquisa FAPESP (Projeto Temático 2014/ 18002-2), concedido ao meu orientador, José Rubens Pirani, que possibilitou a realização de coletas de material botânico, visitas às coleções herborizadas e custeio de despesas com a pesquisa conduzida no laboratório Pfizer do Jardim Botânico de Nova lorque. À International Association for Plant Taxonomy, pelos dois auxílios financeiros que me auxiliaram na realização de coleta de material botânico e na participação no Congresso Internacional de Botânica 2017, na China. À comissão organizadora do Congresso Internacional de Botânica 2017, pelo custeio da inscrição do congresso.

À Universidade de São Paulo, pela estrutura fornecida para 0 desenvolvimento dessa pesquisa. Ao Departamento de Botânica e ao Programa de Pós-Graduação em Botânica do IBUSP, pela excelência no curso de pósgraduação. Ao Jardim Botânico de Nova lorque, pela estrutura oferecida para o desenvolvimento de parte desse projeto.

Aos curadores dos herbários nacionais e internacionais, pela disponibilização de seus acervos, solicitude e assistência na localização e empréstimos de materiais. Em especial, à curadora Rosa Meneses do Herbário Nacional da Bolívia (LPB), pelo auxílio na solicitação de autorização de coleta de material botânico e envio de material, e à curadora Olga Gladys Martínez do Herbário do Museu de Ciências Naturais de Salta (MCNS), pelo auxílio no envio de material botânico.

Aos gestores das Unidades de Conservação do Parque Nacional Aparados da Serra e Parque Nacional de São Joaquim, pela concessão da licença de coleta e auxílio logístico.

Agradeço aos professores do laboratório de Sistemática Vegetal, Dr. Renato de Mello-Silva, Dr. Paulo Takeo Sano e Dra. Lúcia Garcez Lohmann. Aos funcionários do herbário Abel Ribeiro e, em especial, Viviane Jono e Roberta Figueiredo pela amizade e companheirismo. Aos colegas do laboratório de 
Sistemática Vegetal Alison Gonçalves Nazareno, Annelise Frazão, Augusto Giaretta, Beatriz Machado, Camila Monge Dussán, Carolina Andrino, Carolina Sinischalchi, Daniela Costa, Eduardo Leal, Eric Kataoka, Gisele Alves, Guilherme Antar, Jenifer de Carvalho Lopes, Jéssica Nayara Francisco, Juan Pablo Narvaéz, Luiz Henrique Fonseca, Marcelo Devecchi, Marcelo Kubo, Mayla Beyer, Paulo Gonella, Rebeca Laino Gama, Rebeca Viana, Renato Ramos, Verônica Thode. Aos professores e colegas do laboratório de Anatomia Vegetal, em especial Dr. Diego Demarco e Natalie Capelli pela realização do estudo anatômico foliar e floral de Schinus.

À Dra. Patrícia Pierre, pelos estudos citogenéticos e palinológicos em Schinus.

Ao Dr. Jefferson Prado pela solicitude em auxiliar nas questões nomenclaturais.

À Elisabeth Tolke, por realizar e disponibilizar imagens de microscopia eletrônica de varredura das flores de Schinus.

À Fernanda Alves e Eric Lira, pela amizade, carinho e apoio com os mapas.

À Juliana Lovo, pela amizade, companheirismo e generosidade. Pela ajuda na organização do trabalho, inúmeros conselhos e ideias, reuniões e ajuda com a edição das imagens. Obrigada pelo apoio e dedicação, os quais foram essenciais na finalização da tese.

À Juliana El Ottra, amiga que tive a oportunidade de partilhar toda essa etapa de minha vida. Obrigada por me apoiar e por todos os incentivos, os quais foram importantes para concluir meu doutorado. Obrigada pelo apoio na reta final e na edição de imagens.

À Maria Fernanda Calió, amiga em quem pude confiar e contar para a organização e execução deste trabalho. Obrigada pela amizade, carinho, por me apoiar e ajudar a seguir em frente, sempre ajudando a enxergar o melhor nas diversas situações.

Ao Dr. Gregory Plunkett, pelo apoio e orientação, especialmente no estudo filogenético e por me ensinar a ser uma sistemata molecular.

Ao Dr. Douglas Daly, pela orientação, especialmente na taxonomia, pela amizade e inúmeros cafés, os quais contribuíram para que o meu trabalho fosse mais produtivo.

Ao Dr. John Mitchell, pela orientação, especialmente na taxonomia de Anacardiaceae, pelo seu compromentimento com esse projeto e pelo entusiasmo contagiante pelas Anarcardiaceae. 
À Dra. Susan Pell, por me incentivar a estudar sistemática de Schinus e pelo apoio no projeto.

Aos amigos do Jardim Botânico de Nova lorque, pelo convívio tão agradável durante o estágio sanduíche, em especial, Jacquelyn Kallunki, Stella Sylva, William Wayt Thomas, Carlos Rodrigues Vaz, Dario Cavaliere, Robin Sleith, Maria Cristina Marinez e Cecilia Zumajo Cardona. À Bobbi Angel, pelas ilustrações botânicas. Aos amigos brasileiros com quem compartilhei bons momentos, Leonardo Borges, Aline Quaresma, Ana Carolina Costa, Danilo José Lima de Sousa e Vidal Mansano.

Aos meus pais, José e Elisabeth, pelo amor e apoio, ao meu irmão e minha cunhada, Tiago e Kelly, pela amizade, aos meus queridos avós, Antenor e Clotilde, pelo carinho, e aos meus sogros, Neusa e Agnaldo e meus cunhados, Agnaldo e Luiz, pelo apoio durante o estágio-sanduíche. A todos os meus amigos, os quais me fazem perceber como é importante compartilhar os momentos da vida.

Ao Luciano, pelo apoio na execução de todas as etapas desse projeto, principalmente nas viagens de campo, a quem eu atribuo grande parte do sucesso de todo o material coletado. Teria sido muito difícil enfrentar certos "empecilhos" durante as viagens sem a sua assessoria. Obrigada por dirigir mais de $30.000 \mathrm{~km}$ pelo Cone Sul e, principalmente, por estar presente nos momentos memoráveis da minha vida. 


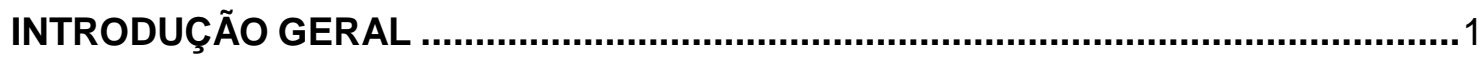

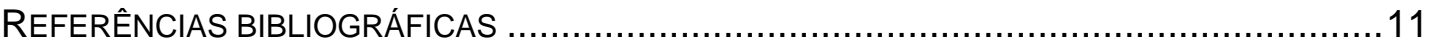

CAPÍTULO 1 - A NOVEL PHYLOGENY-BASED CLASSIFICATION FOR SCHINUS L.

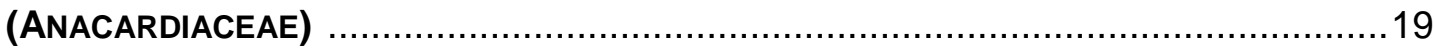

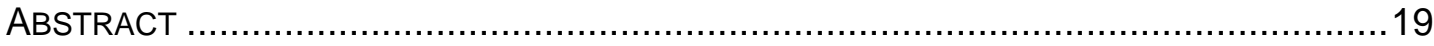

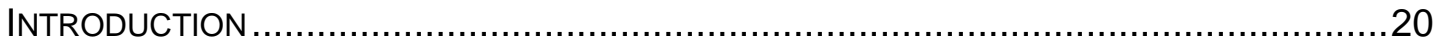

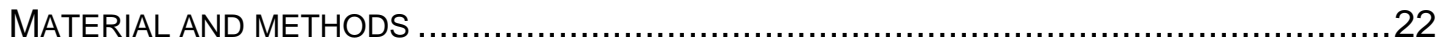

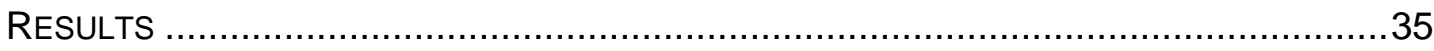

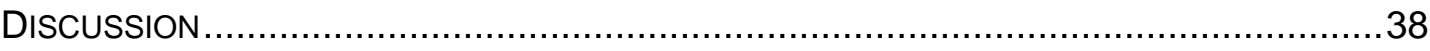

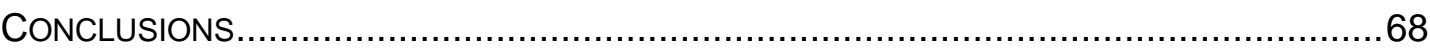

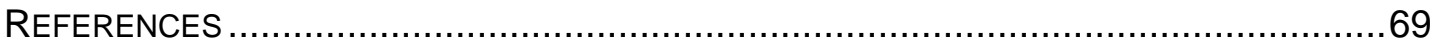

CAPÍTULO 2 - HIDDEN SPECIES IN THE ANDEAN MOIST MONTANE FORESTS: A REVIEW OF SCHINUS SECTION MYRTIFOLIA (ANACARDIACEAE) ........................................... 78

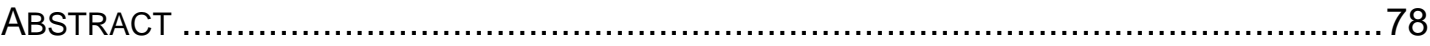

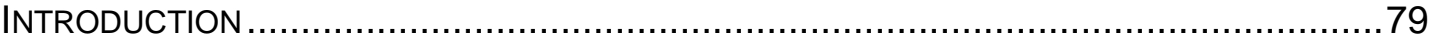

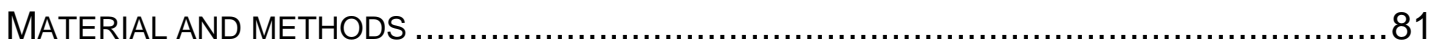

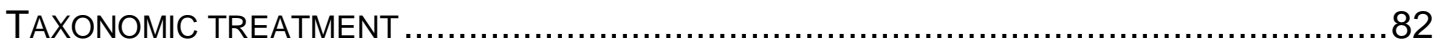

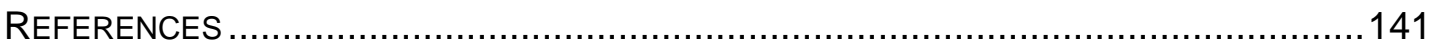

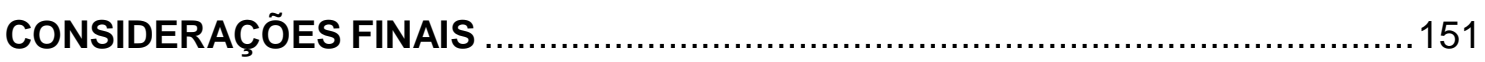

REFERÊNCIAS BIBLIOGRÁFICAS .............................................................. 154

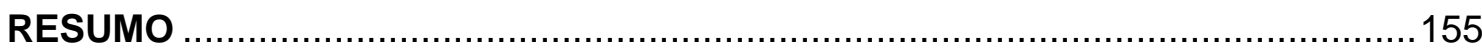

ABSTRACT

ANEXO 1 
As espécies da família Anacardiaceae apresentam importância econômica por fornecerem frutos comestíveis, madeiras úteis ou espécies ornamentais. Da semente do cajueiro (Anacardium occidentale L.) obtém-se a castanha-de-caju, enquanto o pedicelo frutífero suculento (hipocarpo ou fruto acessório) é comercializado in natura. Outros frutos de importância comercial ou regional incluem a manga (Mangifera indica L.), os cajás (Spondias spp.), o umbu (Spondias tuberosa Arruda) e a seriguela (Spondias purpurea L.). Schinus terebinthifolia Raddi, Schinus molle L. e Rhus succedanea L. são exemplos de plantas utilizadas na ornamentação de ruas e praças. Entre as espécies que apresentam madeira de boa qualidade estão o gonçalo-alves (Astronium fraxinifolium Schott ex Spreng.), o guaritá (Astronium graveolens Jacq.), a aroeira (Myracrodruon urundeuva Allemão), a aroeira-branca (Lithrea molleoides (Vell.) Engl.) e a braúna (Schinopsis brasiliensis Engl.) (Souza \& Lorenzi 2005).

Trata-se de uma família monofilética que apresenta como sinapomorfia morfológica a presença de um único óvulo apótropo por lóculo, mas que pode ser facilmente reconhecida por ser um grupo de plantas lenhosas resiníferas, cujas partes jovens apresentam aroma e sabor característicos, semelhantes ao do fruto verde da manga (Mangifera indica). As folhas são simples ou compostas, e as flores são dialipétalas, isostêmones ou obdiplostêmones, às vezes diplostêmones, com ovário súpero geralmente uni ou tricarpelar, mas unilocular e uniovulado, produzindo frutos carnosos ou secos unisseminados (Bachelier \& Endress 2009; Pell et al. 2011).

$\mathrm{Na}$ classificação intrafamiliar, Bentham \& Hooker (1862) distinguiram duas tribos: Anacardieae e Spondieae. Posteriormente, em duas grandes monografias, Engler $(1883,1896)$ dividiu a família em cinco tribos: Mangiferae (=Anacardieae), Spondieae (=Spondiadeae), Rhoideae (=Rhoeae), Semecarpeae e Dobineeae (=Dobinaeae). Embora as obras desse autor contivessem a revisão mais minuciosa e ampla de Anacardiaceae, o conjunto de caracteres utilizado em cada tribo era diferente, gerando, consequentemente, sobreposição entre os limites tribais (Pell 2004). Mais recentemente, Pell (2004) executou uma análise filogenética de Anacardiaceae, utilizando sequências de três marcadores moleculares de cloroplasto, obtendo dois clados principais que foram resolvidos em sua maioria por meio de sequências de trnL-F. Tais clados correspondem às subfamílias citadas por Terrazas (1994 apud Mitchell et al. 2006), especificamente Anacardioideae e Spondioideae. Na proposta de Pell (2004), a subfamília Anacardioideae 
compreende quatro das tribos de Engler (1896): Anacardieae, Dobinaeae, Rhoeae, Semecarpeae, porém incluindo também muitos gêneros não conhecidos por ele naquela época. A subfamília Spondioideae corresponde à tribo Spondiadeae sensu Engler expandida.

Anacardiaceae pertence à ordem Sapindales, pertencente ao grupo das eudicotiledôneas rosídeas malvídeas. Possui aproximadamente 81 gêneros e 800 espécies, presentes em ambientes secos a úmidos, principalmente em terras baixas nas regiões tropicais e subtropicais em todo o mundo, estendendo-se até regiões temperadas (Pell et al. 2011). Nas Américas, existem aproximadamente 32 gêneros nativos, sendo que $77 \%$ das espécies são endêmicas do continente americano e apenas os gêneros Antrocaryon Pierre, Campnosperma Thwaites, Cotinus Mill., Pistacia L., Rhus L., Spondias L. e Toxicodendron Mill. possuem representantes em outros continentes também (Terrazas 1999). No Brasil, estão catalogados 14 gêneros com 55 espécies de Anacardiaceae, sendo que 16 delas são restritas ao país (Silva-Luz \& Pirani 2017). As regiões brasileiras apresentam um número relativamente semelhante de espécies de Anacardiaceae, sendo a região Norte, com 28 spp., a que possui maior número de táxons, seguida da região Sudeste com 27 spp., região Nordeste com 24 spp., região Centro-oeste com 23 spp. e a região Sul com 19 spp. Nas regiões Norte e Sul do Brasil, o padrão de distribuição difere das demais regiões em relação ao número de espécies regionais, sendo que Anacardium L. e Thyrsodium Salzm. ex Benth. são os gêneros com maior riqueza específica no norte, enquanto Schinus L. é o principal representante no sul. No que concerne à taxonomia desses gêneros, alguns trabalhos de revisão já foram realizados (Barkley 1944, 1957, Mitchell \& Mori 1987, Mitchell \& Daly 1993) e a delimitação entre os táxons de Anacardium e Thyrsodium, de forma geral, está bem estabelecida, ao passo que em Schinus, a identificação e a delimitação em algumas espécies ainda não estão claras.

Algumas espécies de Schinus apresentam madeira de boa qualidade e uso na medicina popular brasileira, devido a potencial atividade antifúngica, antimicrobiana, inseticida, antibacteriana e cicatrizante (Santos et al. 2010). Schinus apresenta espécies pioneiras usadas em arborização urbana e nas etapas iniciais de reflorestamento de áreas perturbadas, tais como $S$. molle e $S$. terebinthifolia. Os frutos da última espécie são atrativos da fauna, principalmente da avifauna (Krügel \& Berh 1998). Algumas espécies são utilizadas regionalmente na confecção de arranjos para decoração, é o caso de $S$. weinmanniifolia Mart. ex Engl. Em relação à importância econômica, as sementes de $S$. terebinthifolia e $S$. molle, conhecidas como pimenta-rosa ou pimenta-da-jamaica, têm sido 
amplamente utilizadas na culinária nacional e internacional, pois apresentam um sabor suave e levemente picante. No que se refere às espécies cultivadas e invasoras, S. terebinthifolia, nativa da Argentina, Uruguai e Brasil, conhecida como aroeira-mansa, foi introduzida em áreas subtropicais em todo mundo (Ewel et al. 1982). Na Flórida e Havaí, esta espécie foi introduzida como planta ornamental e tornou-se uma das espécies invasoras mais amplamente distribuídas e nocivas desses estados (Schmitz et al. 1997). Schinus areira L., espécie nativa da América do Sul, foi introduzida como planta ornamental e tornou-se bem estabelecida na América Central, México e nas regiões temperadas quentes e subtropicais do mundo (Barkley 1957). Na África do Sul, é classificada como a principal planta daninha (Nel 2004), sendo que, recentemente, começou a invadir as savanas semiáridas naturais da província do Cabo (Iponga et al. 2009).

O contexto de carência de estudos nesse gênero de importância biológica e econômica motivou o planejamento do presente trabalho. Schinus, em sua circunscrição atual, é reconhecido como um grupo monofilético e tem como gêneros mais proximamente relacionados Lithrea Miers ex Hook. \& Arn., Mauria Kunth, Euroschinus Hook. f., Schinopsis Engl., Myracrodruon Allemão, Astronium Jacq., Loxopterygium Hook. f., Ochoterenaea F.A. Barkley, Thyrsodium Salzm. ex Benth., Cardenasiodendron F.A. Barkley, Apterokarpos Rizzini, Orthopterygium Hemsl. e Amphipterygium Schiede ex Standl. (Weeks et al. 2014). Cabe ressaltar, entretanto, que poucas espécies de Schinus foram amostradas nos estudos filogenéticos já executados em Anacardiaceae ou Sapindales. Em tais estudos, representantes de Schinus foram amostrados apenas como constituintes de grupoexterno (Miller et al. 2001; Yi et al. 2004, 2007, 2008; Pell et al. 2008; Nie et al. 2009; Al-Saghir 2010; Xie et al. 2014). Recentemente, amostras de cinco espécies de Schinus foram utilizadas numa reconstrução da filogenia de Anacardiaceae e Burseraceae, a qual forneceu evidências preliminares da monofilia do gênero (Weeks et al. 2014). Trata-se de um gênero de fácil reconhecimento por apresentar morfologia característica e marcante, pelo menos nas espécies mais conhecidas, tais como: folhas compostas pinadas, raque alada, inflorescência em panícula e drupas globosas, geralmente rosadas ou avermelhadas, com epicarpo fino e lustroso que, quando maduro, se separa do mesocarpo negro e resinífero que envolve o pireno coriáceo (endocarpo envolvendo uma só semente). Mesmo comparando com o gênero mais próximo (Lithrea), onde também ocorrem raques aladas e drupas com epicarpo fino e destacado do pireno, Schinus distingue-se consistentemente pela placentação subapical (vs. basal em Lithrea). A controvérsia sobre o gênero correto do nome Schinus envolvendo variantes ortográficas (i.e., 
terminação em -us ou -a) foi recentemente reavaliada por Zona (2015). Isto se deve ao fato de que a análise dos primeiros seis epítetos descritos por Linnaeus (1753) não revela o gênero gramatical de Schinus, pois cinco são nomes (substantivos) e somente um é adjetivo, S. tragodes L. No entanto, a terminação -es (tragodes) é utilizada tanto para o masculino como para o feminino. A etimologia de "Schinus" vem do grego Schinos (lentisco em latim; mastic em inglês), nomes que se referem a Pistacia lentiscus L., o pistache, pertencente à mesma família. Ambos nomes são tratados em latim e em grego como gênero gramatical feminino (Gaffiot 1934), uma vez que trata-se de uma espécie arbórea. Na gramática latina (Stearn 1980), as palavras da segunda declinação (genitivo singular -l), cujo nominativo singular é us, sendo que frequentemente representam a terminação -os de origem grega são considerados principalmente como gênero gramatical masculino, com algumas exceções, por exemplo para espécies arbóreas (e.g., Cedrus, Pinus, Ficus). Além disso, na quarta declinação o nominativo singular também é -us (com o genitivo singular também -us) e tratado no masculino, mas novamente com exceções (e.g., Quercus). De acordo com o artigo 62.1 do Código Internacional de Nomenclatura Botânica (McNeill et al. 2011), um nome genérico retém o gênero atribuído pela tradição botânica, independente do uso clássico ou uso do autor original. Um nome genérico sem tradição botânica retém o gênero gramatical estipulado por seu autor. Uma vez que o código recomenda seguir a tradição botânica, neste caso espécies arbóreas são tratadas como nomes genéricos femininos, o uso do feminino na terminação dos epítetos de Schinus parece ser o mais apropriado e também o adotado nesse trabalho.

Schinus foi descrito por Linnaeus (1753), sendo que as espécies com folhas compostas pinadas tornaram-se a base para a caracterização morfológica do gênero. Cavanilles (1795) descreveu um táxon com folhas simples como Amyris polygama (Cav.) Kunth, posteriormente transferido para Schinus por Candolle (1825), consequentemente, ampliando a circunscrição do gênero. De acordo com a revisão do gênero (Barkley 1944, 1957), são reconhecidas em Schinus 28 espécies e 17 variedades, distribuídas em dois subgêneros caracterizados por uma combinação de caracteres nem sempre consistentes. Schinus subg. Schinus (Euschinus) apresenta folhas compostas pinadas e panículas, enquanto $S$. subg. Duvaua (Euduvaua) (Kunth.) F.A. Barkley tem folhas simples e pseudorracemos. Neste último subgênero, Barkley $(1944,1957)$ reconheceu duas seções, S. subg. Duvaua sect. Duvaua e S. subg. Duvaua sect. Pseudoduvaua F.A. Barkley, no entanto estudos taxonômicos subsequentes têm demonstrado que os táxons da primeira seção possuem delimitação de espécies ainda muito controvertida. Por 
exemplo, Cabrera (1938) e Fleig (1989) consideraram muitos dos binômios publicados como sinônimos de S. polygama (Cav.) Cabr. sensu lato, enquanto Barkley (1957) descreveu e reconheceu várias espécies distintas, cerca de 15 espécies e cinco variedades, sobretudo com base na morfologia foliar. Contudo, observações recentes mostram que esses táxons apresentam helicomorfia, ou seja, os protofilos são mais complexos do que os metafilos (Steibel \& Troiani 2005). Dessa maneira, é possível observar variações na forma e dimensões da folha relacionadas ao estádio de desenvolvimento (Steibel \& Troiani 2008). Devido a estas variações, alguns táxons foram descritos como inéditos, porém tratam-se, na realidade, de indivíduos em estádio juvenil. Tal fato foi evidenciado em $S$. dependens Ortega subsp. subintegra Engl. fo. arenicola Hauman, táxon que apresenta marcante instabilidade taxonômica. A análise de plantas vivas, adultas e juvenis, procedentes da mesma localidade do espécime-tipo, associada ao estudo de plântulas e juvenis cultivadas a partir de sementes, demonstraram que esse táxon corresponde a um indivíduo juvenil de S. johnstonii F.A. Barkley (Steibel \& Troiani 2008).

Isto demonstra a complexidade e a dificuldade de delimitação entre as espécies de Schinus. Além disso, só no Estado de São Paulo, para uma mesma espécie de Schinus de folhas simples com ramos terminando em um espinho, pelo menos quatro nomes são tradicionalmente empregados: $S$. ramboi F.A. Barkley, $S$. engleri F.A. Barkley e S. Iongifolia (Lindl.) Speg. e S. polygama (Cav.) Cabrera. Com base no estudo dos protólogos e na análise dos materiais-tipo, Silva-Luz (2012) verificou que S. longifolia e S. polygama apresentam caracteres reprodutivos que claramente as distinguem das demais espécies. Além disso, a primeira espécie ocorre no Brasil, Paraguai e Argentina, enquanto a segunda é endêmica do Chile. No entanto, distinção entre $S$. engleri e $S$. ramboi ainda é complicada, devido à grande sobreposição dos caracteres vegetativos e reprodutivos. O estudo morfológico de ampla amostragem, incluindo os tipos nomenclaturais, somado à distribuição geográfica coincidente, aponta que talvez esses dois últimos táxons sejam conspecíficos.

As categorias infragenéricas de Schinus foram propostas por Barkley (1944, 1957) para adequar as espécies de folhas simples do subgênero Duvaua. Entretanto, devido à sobreposição dos caracteres tradicionalmente utilizados na classificação infragenérica, Fleig $(1979,1987)$ acredita que essa subdivisão do gênero seja pouco consistente devido à ausência de caracteres robustos que auxiliem na caracterização da circunscrição proposta. Por exemplo, S. pearcei Engl. (S. subg. Schinus) apresenta folhas simples e compostas e inflorescência do tipo 
panícula, enquanto S. pilifera I.M. Johnst. (S. subg. Duvaua) possui folhas simples e também inflorescência do panícula, porém muito contraída. O estudo ontogenético da formação dos óvulos (rudimentos seminais) em S. terebinthifolia e S. polygama, táxons que apresentam folhas compostas e simples respectivamente, demonstrou que na primeira espécie ocorre crescimento do rudimento seminal em direção à base da cavidade locular e o surgimento do tegumento interno é simétrico dorsoventralmente, ao passo que na segunda espécie, esse órgão cresce contra a parede da cavidade locular e o surgimento do tegumento interno é assimétrico dorsoventralmente (Rodrigues et al. 2004). Tais resultados são bastante intrigantes e sugerem que o estudo da evolução de atributos morfológicos particulares como os óvulos seja muito promissor nesse grupo.

Além disso, a investigação do padrão evolutivo das estruturas vegetativas e do tipo de inflorescência também parece ser particularmente interessante, dada sua grande importância nas classificações tradicionais do gênero.

Em síntese, apesar de Schinus ser geralmente um grupo de fácil reconhecimento, é evidente que ainda existem problemas taxonômicos que necessitam de estudos morfológicos detalhados, principalmente em relação à definição de caracteres robustos tanto para sustentar as categorias infragenéricas quanto para aprimorar a circunscrição das espécies e variedades problemáticas.

Um outro aspecto interessante de Schinus é a sua distribuição geográfica, pois trata-se de um gênero sul-americano com as espécies concentradas na Argentina estendendo-se ao Uruguai, Paraguai, Bolívia, Brasil, Peru e Chile (Barkley 1957, Pell et al. 2011).

A região austral da América do Sul, local cuja riqueza específica de Schinus é alta, possui atualmente grande diversidade de climas, ambientes, biomas e biotas. Essa região abrange 15 das 24 províncias biogeográficas sulamericanas (Cabrera \& Willink 1980) e 10 dos 11 biomas reconhecidos para todo o continente (Olson \& Dinerstein 2002). Os biomas secos ou áridos continentais são os mais bem representados nessa região (Ortiz-Jaureguizar \& Cladera 2006) e incluem diversos ambientes, tais como: deserto do Atacama no Chile e Peru, o Chile central, os cerrados e as caatingas no Brasil, as punas andinas, os bosques chaquenhos, os montes no centro-oeste da Argentina e as estepes na Patagônia (Ocampo 2008). Ainda são controvertidas as hipóteses sobre a origem e antiguidade dessas formações vegetacionais sob climas áridos e semi-áridos, pois alguns estudos sugerem que elas tenham se estabelecido recentemente (Terciário superior) e que atingiram sua extensão máxima durante o Plioceno Médio e o Quaternário (Lewis 1966, Raven \& Axelrod 1974). No entanto, outros estudos 
afirmam que essas formações são muito antigas e que, embora por alguns períodos tenham sido pouco expressivas em extensão, já estariam presentes ao longo do Terciário e até mesmo no Jurássico (Roig-Juñent et al. 2006).

As zonas áridas da América do Sul meridional constituem um aglomerado de áreas de endemismo cujos componentes bióticos parecem compartilham histórias biogeográficas, sendo que este subcontinente é constituído por partes adjacentes de duas regiões biogeográficas, a Neotropical e a Andina (Cabrera \& Willink 1980, Morrone 2006), e ainda pela Zona de transição da América do Sul (Morrone 2006, 2014). Por apresentar áreas de endemismos, a região austral da América do Sul tem sido foco de muitos estudos tanto de cunho biogeográfico (e.g. Crisci et al. 1991, Juñent 1994, Hinojosa 2005, Ortiz-Jaureguizar \& Cladera 2006, Moreira-Muñoz 2007) quanto florístico, como o Catálogo de las plantas vasculares del Cono Sur (Zuloaga et al. 2008), Flora do Chile (Marticorena \& Rodríguez 1995), Catálogo de las plantas vasculares de la República Argentina (Zuloaga \& Morrone 1996, 1999), Catálogo de las plantas vasculares de Bolivia (www.tropicos.org) e no Brasil, a Flora llustrada Catarinense (Reitz 1985) e Flora digital do Rio Grande do Sul e de Santa Catarina (www6.ufrgs.br).

Para bom desenvolvimento desses estudos biogeográficos, com base nas linhagens de organismos que constituem cada bioma ou região, atualmente é imperativo basear-se no paradigma primordial da Sistemática moderna e da Biologia Comparada: a Sistemática Filogenética, cujas bases foram propostas por Hennig $(1965,1966)$ e, subsequentemente, passaram por muito desenvolvimento e novas elaborações, tornando-se amplamente empregadosa em muitos campos além da biologia. Além da importância do conhecimento da morfologia dos grupos de organismos, desde dos anos 90 tem sido possível incorporar caracteres moleculares nas análises filogenéticas, sendo que estes constituem um universo diversificado de dados independentes e simultaneamente testáveis (Jenner 2004, Wiens 2004, Smith \& Turner 2005, Bybee et al. 2009). Embora numerosas filogenias baseadas estritamente em dados macromoleculares estejam sendo continuamente publicadas, muitos autores defendem que apenas a combinação de caracteres morfológicos e moleculares permite estabelecer um conhecimento compreensivo e integrado da biodiversidade. Este é de extrema importância para a redução do impedimento taxonômico vigente em muitos países, bem como representa a base para os inventários de biodiversidade, elaboração de floras, estudos biogeográficos e filogeográficos, e para o estabelecimento de prioridades para a conservação da biodiversidade (Wheeler 2004, 2008, Wheeler et al. 2004, Franz 2005, Funk 2006, Carvalho et al. 2005, 2007, Mooers 2007, Avise 2009). 
Estudos sistemáticos e evolutivos em Anacardiaceae, como nos gêneros Pistacia, Protorhus Engl., Rhus e Toxicodendron, têm sido produzidos utilizando como base as filogenias moleculares (Miller et al. 2001, Yi et al. 2007, 2008, Pell et al. 2008, Nie et al. 2009). Estes estudos elucidam o posicionamento e o relacionamento entre os táxons em vários níveis hierárquicos (e.g., complexos, níveis intragenéricos e interespecíficos), auxiliam na resolução dos problemas de delimitação e testam a monofilia de táxons previamente descritos. Adicionalmente, árvores filogenéticas, quando datadas (cronogramas), permitem a inferência do padrão de acumulação das linhagens no tempo, o cálculo do tempo mínimo de origem dos grupos monofiléticos, estimativa de quando as linhagens chegaram a diferentes áreas geográficas. Além disso, potenciais inovações-chave podem ser mapeadas em filogenias moleculares robustas e a sua origem datada (Pennington et al. 2004). No entanto, ainda são escassos os estudos sistemáticos e macroevolutivos na família Anacardiaceae, principalmente em relação aos táxons que ocorrem na região Neotropical.

Dentro dessa perspectiva, o desenvolvimento de um estudo filogenético do gênero Schinus será de grande importância por viabilizar testes da monofilia do gênero, da monofilia das categorias infragenéricas tradicionalmente reconhecidas e ainda por contribuir para o entendimento das relações interespecíficas. Consequentemente, será possível produzir uma classificação para o gênero mais consistente e aliada a uma revisão baseada também em princípios da Sistemática Filogenética.

Como referido anteriormente, uma filogenia robusta do gênero permitiria ainda realizar análises visando à compreensão dos padrões biogeográficos das espécies de Schinus. Em particular, é importante mencionar que a família Anacardiaceae, e inclusive o gênero Schinus, constitui-se um grupo de estudo interessante por apresentar diversos registros fósseis (Romero 1978, 1986, 1993, Troncoso \& Romero 1998). Embora seja necessária uma análise prévia cuidadosa desses fósseis, tais registros auxiliam no entendimento das vegetações pretéritas em diversos locais, por exemplo na Patagônia, cujos fósseis de Anacardiaceae parecem constituir boas evidências da existência de áreas dominadas por arbustos e arvoretas adaptados a condições áridas durante o Eoceno. Além disso, dessa época em diante, intervalos quentes foram caracterizados pelo aumento progressivo no número de táxons (e.g., Anacardiaceae) que atualmente são frequentes nas florestas tropicais sazonais secas da América do Sul (Barreda \& Palazzesi 2007). Este fato pode corroborar a hipótese de que essas florestas já foram amplamente distribuídas e mais expressivas durante períodos mais frios e 
secos do Pleistoceno (Prado \& Gibbs 1993). O estudo biogeográfico de Schinus e de táxons relacionados de Anacardiaceae parecem muito promissoras para ampliar o conhecimento sobre a história das formações vegetacionais da América do Sul Austral, uma vez que os táxons desse gênero possivelmente foram em um passado distante, e são atualmente, elementos marcantes dessas formações vegetacionais.

Nesse contexto, esta tese de doutorado teve como objetivos principais o estudo filogenético baseado em dados moleculares de Schinus e de gêneros de Anacardiaceae proximamente relacionados, o teste da monofilia de Schinus e das categorias infragenéricas, e a investigação acerca das relações filogenéticas no gênero. Além disso, este trabalho envolveu um estudo morfológico, incluindo atributos anatômicos vegetativos, visando a identificar caracteres estruturais que sejam possíveis sinapormofias dos principais clados, e a discutir as hipóteses sobre a evolução desses caracteres na história evolutiva de Schinus. Por fim, o estudo filogenético aqui desenvolvido permitiu delinear uma nova classificação seccional no gênero e programar a realização de estudos taxonômicos de cada seção, iniciando-se com a revisão de uma delas.

Assim, no capítulo 1 desta tese apresentamos a filogenia de Schinus, baseada em sequências de DNA de 11 marcadores, sendo nove nucleares e dois plastidiais. A amostragem baseou-se na última revisão taxonômica do gênero e incluiu 47 táxons de Schinus. A escolha do grupo-externo foi baseada no estudo de Weeks et al. (2014), sendo amostradas espécies de 13 gêneros, totalizando 48 táxons. Foram realizadas análises filogenéticas individuais e combinadas utilizando inferências Bayesiana, máxima parcimônia e de máxima verossimilhança. Elaboramos uma matriz morfológica, incluindo caracteres vegetativos anatômicos, baseada na análise de materiais herborizados e fixados provenientes de coletas a campo estrategicamente realizadas em pontos selecionados da ampla distribuição do grupo focal, para obtenção de amostras de todos os táxons conhecidos de Schinus. A reconstrução de estados ancestrais de vários caracteres morfológicos foi realizada pelo critério de parcimômia, utilizando como base a árvore filogenética proveniente da análise combinada Bayesiana. Essa reconstrução morfológica teve como principais objetivos: 1 . buscar um entendimento mais amplo sobre as relações interespecíficas em Schinus e entre gêneros proximamente relacionados, 2 identificar caracteres morfológicos e possíveis sinapormofias dos principais clados, e 3. discutir as hipóteses sobre a evolução de caracteres estruturais em Schinus. De acordo com as novas evidências provenientes desse estudo, apresentamos no primeiro capítulo uma nova classificação seccional em Schinus, assim como chave de identificação para as oito seções, lista de espécies 
compondo cada seção, além de comentários taxonômicos, de distribuição geográfica e sobre ecologia. Este capítulo será submetido à Molecular Phylogenetics and Evolution e terá como um de seus co-autores o Dr. José Rubens Pirani. O estudo filogenético apresentado aqui é o resultado da colaboração entre pesquisadores brasileiros e estadunidenses, sendo que os dados moleculares foram obtidos no laboratório Pfizer do Jardim Botânico de Nova lorque (EUA) e teve como colaborador principal o pesquisador Dr. Gregory M. Plunkett. Outros pesquisadores da mesma instituição como Dr. Douglas Daly e Dr. John D. Mitchell participaram principalmente nas discussões dos dados obtidos. A Dra. Susan K. Pell, pesquisadora do Jardim Botânico Nacional (Washington, EUA), colaborou disponibilizando amostras de táxons de Anacardiaceae e nas discussões sobre marcadores moleculares e dados obtidos. O estudo anatômico foliar foi realizado pela bolsista TT3 (treinamento técnico) e hoje mestranda Natalie Capelli, sob orientação do professor Dr. Diego Demarco, ambos pesquisadores do laboratório de Anatomia Vegetal do Departamento de Botânica da Universidade de São Paulo. Dessa maneira, o artigo terá também como co-autores os pesquisadores acima mencionados.

No capítulo 2 desta tese, apresentamos a revisão taxonômica de Schinus sect. Myrtifolia, que pretendemos ser o primeiro de uma série tratamentos taxonômicos planejados para todas as seções propostas no capítulo 1 . Apresentamos uma chave de identificação para as espécies, descrições morfológicas, sinonímia, tipos nomenclaturais, incluindo três lectotipificações, duas combinações novas, ilustrações, mapas de distribuição, dados sobre habitats e avaliação do estado de conservação de todas as espécies. As ilustrações desse capítulo foram realizadas pela artista Bobbi Angel. No final do capítulo apresentamos uma lista preliminar de exsicatas, a qual será completada antes de ser submetida para a publicação com os inúmeros registros de herbários consultados durante a execução desse trabalho. Este capítulo será submetido à Botanical Journal of the Linnean Society e terá como co-autores o Dr. José Rubens Pirani, Dr. Douglas Daly e Dr. John D. Mitchell.

Esperamos que a tese constitua contribuição relevante ao aprimoramento do conhecimento desse gênero e de sua família, bem como possa auxiliar nos estudos sobre a diversificação e história biogeográfica da biota sulamericana austral. 
Avise, J.C. 2009. Phylogeography: retrospect and prospect. Journal of Biogeography 36: 3-15.

Bachelier, J.B., Endress, P.K., 2009. Comparative floral morphology and anatomy of Anacardiaceae and Burseraceae (Sapindales), with a special focus on gynoecium structure and evolution. Botanical Journal of the Linnean Society 159: 499-571.

Barkley, F.A., 1944. Schinus L. Brittonia 5(2): 160-198.

Barkley, F.A. 1957. A study of Schinus L. Lloydia 28: 5-110.

Barreda, V. \& Palazzesi, L. 2007. Patagonian vegetation turnovers during Paleogene-Early Neogene: origin of arid-adapted floras. The Botanical Review 73(1): 31-50.

Bentham, G. \& Hooker, J.D. 1862. Genera Plantarum. Vol. 1. L. Reeve \& Co., London.

Burnham, R.J. \& Graham, A. 1999. The history of Neotropical vegetation: new developments and status. Annals of the Missouri Botanical Garden 86(2): 546589.

Bybee, S.M., Zaspel, J.M., Beucke, K.A., Scott, C.H., Smith, B.W. \& Branham, M.A. 2009. Are molecular data supplanting morphological data in modern phylogenetic studies? Systematic Entomology 35: 2-5.

Cabrera, A.L. 1938. Revision de las Anacardiáceas Austroamericanas. Revista del Museo de La Plata NS 2: Bot. 6: 1-64.

Cabrera, A.L. \& Willink, A. 1980. Biogeografia da America Latina. 2 ed. Washington, OEA.

Candolle, A.P. 1825. Prodomus Systematis Naturalis Regni Vegetabilis. Paris, vols. 1 e 2.

Carvalho, C.J. \& Almeida, E.A.B. (orgs.). 2011. Biogeografia da América do Sul: padrões e processos. São Paulo: Roca Editora, $306 \mathrm{p}$.

Cavanilles, A.J. 1795. Icones et descriptiones plantarum, quae aut sponte in Hispania crescunt, aut in hortis hospitantur. Vol. III. Matriti: Ex Regia Typographia (Eius operas dirigente Lazaro Gayguer).

Chase, M. W. \& Hills, H. G. 1991. Silica gel: an ideal material for field preservations of samples for DNA studies. Taxon 40: 215-220.

Clapperton, C.M. 1998. Late quaternary glacier fluctuations in the Andes: testing syncrony of global change. Quaternary Proceedings 6: 65-73.

Collins, E.S., Gostel, M.R., Weeks, A., 2016. An expanded nuclear phylogenomic 
PCR toolkit for Sapindales. Applications in Plant Sciences 4(12): 1600078.

Crisci, J.V., Cigliano, M.M., Morrone, J.J., Roig-Juñent, S. 1991. Historical biogeography of southern South America. Systematic Zoology 40: 152-171.

De Pinna, M.C.C. 1991. Concepts and tests of homology in the cladistic paradigm. Cladistics 7: 367-394.

Drummond, A.J. \& Rambaut, A. 2007. BEAST: Bayesian evolutionary analysis by sampling trees. BMC Evolutionary Biology 7: 214.

Drummond, A.J., Ashton, B., Cheung, M., Heled, J., Kearse, M., Moir, R., StonesHavas, S., Thierer, T. \& Wilson, A. 2009. Geneious v4.7. Disponível em: http://www.geneious.com/.

Edgar, R.C. 2004. MUSCLE: multiple sequence alignment with high accuracy and high throughput. Nucleic Acids Res. 32: 1792-1797.

Ellis, B., Daly, D.C., Hickey, L.J., Johnson, K.R., Mitchell, J.D., Wilf, P. \& Wing, S.L. 2009. Manual of leaf architecture. Cornell University Press, $190 \mathrm{p}$.

Engler, A. 1876. Anacardiaceae. In Martius, C.F.P. \& Eichler, A.G. (eds.) Flora brasiliensis. Fleischer, Leipzig, vol.12, pars 2, p. 367-418.

Engler, A. 1883. Anacardiaceae. In De Candolle, A. \& De Candolle, C. (eds.) Monographiae Phanerogamarum. Masson, Paris, vol. 4, p. 171-500.

Engler, A. 1896. Rutaceae, Simaroubaceae, Burseraceae, Anacardiaceae. In Engler, A. \& Plantl, K. (eds.) Die natürlichen Pflanzenfamilien. Wilhelm Engelmann, Leipzig, Teil 3(5), p. 95-257.

Ewel, J.J. 1986. Invasibility: Lessons from South Florida. In H. A. Moony and J. A. Drake (eds) Ecology of biological invasions of North Samerica and Hawaii, Ecological Studies 58: 214-230.

Farris, J.S., Kallersjo, M., Kluge, A.G. \& Bult, C. 1994. Testing significance on incongruence. Cladistics 10: 315-319.

Felsenstein, J. 1985. Confidence limits on phylogenies: an approach using the bootstrap. Evolution 39: 783-791.

Fitch, W.M. 1971. Toward defining the course of evolution: Minimum change for a specific tree topology. Systematic Zoology 20: 406-416.

Fleig, M. 1979. Estudo taxonômico da família Anacardiaceae no Rio Grande do Sul. Dissertação de Mestrado. Universidade Federal do Rio Grande do Sul, Porto Alegre.

Fleig, M. 1987. Anacardiaceae: flora ilustrada do Rio Grande do Sul. Boletim do Instituto de Biociências, Porto Alegre 42: 1-72.

Fleig, M. 1989. Anacardiáceas. In R. Reitz (ed.) Flora llustrada catarinense. Herbário Barbosa Rodrigues, Itajaí, 64 p. 
Franz, N.M. 2005. On the lack of good scientific reasons for the growing phylogeny/classification gap. Cladistics. 21: 495-500.

Funk, V.A. 2006. Floras: a model for biodiversity studies or a thing of the past? Taxon 55: 581-588.

Gaffiot, F. 1934. Dictionnaire Latin-Français. Hachette, Paris.

Giehl, E.L.H. (coordenador). 2012. Flora digital do Rio Grande do Sul e de Santa Catarina. Disponível em: http://ufrgs.br/floradigital. Acessado em: 22/8/2012.

Gift, N. \& Stevens, P.F. 1997. Vagaries in the delimitation of character states in quantitative variation - An experimental study. Systematic Biology 46(1): 112125.

Gostel, M.R., Coy, K.A., Weeks, A., 2015. Microfluidic PCR-based target enrichment: A case study in two rapid radiations of Commiphora (Burseraceae) from Madagascar. Journal of Systematics and Evolution 53(5): 411-431.

Graham, A. 2010. Late Cretaceous and Cenozoic History of Latin American Vegetation and Terrestrial Environments. St. Louis: Missouri Botanical Garden Press, $617 \mathrm{p}$.

Hennig, W. 1965. Phylogenetic systematics. Annual Review of Ecology and Systematics 10: 97-116.

Hennig, W. 1966. Phylogenetic systematics. University of Illinois Press, Urbana, IL. Huelsenbeck, J.P. \& Ronquist, F. 2001. Mr.Bayes: Bayesian inference of phylogenetic trees. Bioinformatics 17: 754-755.

Iponga, D.M., Milton, S.J. \& Richardson, D.M. 2009. Performance of seedlings of the invasive alien tree Schinus molle L. under indigenous and alien host trees in semi-arid savanna. Africa Journal of Ecology 48: 155-158.

IUCN. 2008. Guidelines for Using the IUCN Red List Categories and Criteria. Version 7.0. Prepared by the Standards and Petitions Working Group of the IUCN SSC Biodiversity Assessments Sub-Committee in August 2008. Disponível em: http://intranet.iucn.org/webfiles/doc/SSC/RedList/RedListGuidelines.pdf

Jenner, R.A. 2004. Accepting partnership by submission? Morphological phylogenetics in a molecular millennium. Systematic Biology 53: 333-342.

Johnston, I.M. 1938. Journal Arnold Arboretum 19(3): 191-290.

Juñent, S.R. 1994. Historia Biogeografica de América del Sur Austral. Multequina 3: 167-203.

Krügel, M.M. \& Berh, E.R. 1998. Utilização dos frutos de Schinus terebinthifolius Raddi (Anacardiaceae) por aves no parque do Ingá, Maringá, Paraná. Revista Biociências 2: 47-56.

Lewis, H. 1966. Speciation in flowering plants. Science 152: 167-172. 
Linnaeus, C. 1753. Species Plantarum. Salvius, Stockholm.

Maddison, D.R. \& Maddison, W.P., 2005. MacClade4 (Versão 4.08): analysis of phylogeny and character evolution. Sinauer, Sunderland, Massachusetts, USA.

Maddison, W.P. \& Maddison, D.R. 2009. Mesquite: a modular system for evolutionary analysis. Version $2.72 \mathrm{http} / / /$ mesquiteproject.org.

Marchand, N.L., 1869. Révision du groupe des Anacardiacées. Balliere, Sons, Paris.

Marticorena, C. \& R. Rodríguez, eds. 1995. Flora de Chile. Vol. 1. Universidad de Concepción.

McNeill, J., Barrie, F.R., Burdet, H.M., Demoulin, V., Hawksworth, D., Marhold, K., Nicolson, D.H., Prado, J., Silva, P.C., Skog, J.E., Wiersema, J.E.H. \& Turland, N.J. (eds.). 2006. International Code of Botanical Nomenclature (Vienna Code) adopted by the Seventeenth International Botanical Congress Vienna, Austria, July 2005. Regnum Vegetabile 146. Ruggell, Liechtenstein: Gantner.

Miller, A., Young, D.A. \& Wen, J. 2001. Phylogeny and Biogeography of Rhus (Anacardiaceae) based on ITS sequence data. International Journal of Plant Sciences 162(6): 1401-1407.

Missouri Botanical Garden. 2012. Catálogo de las Plantas Vasculares de Bolivia. Disponível em http://www.tropicos.org/projectwebportal.aspx?pagename=Home\&projectid=13. Acessado em 22/8/2012.

Mitchell, J.D. \& Daly, D.C. 1993. A revision of Thyrsodium (Anacardiaceae). Brittonia 45(2): 115-129.

Mitchell, J.D., Daly, D.C., Pell, S.K. \& Randrianasolo, A. 2006. Poupartiopsis gen. nov. and its context in Anacardiaceae classification. Systematic Botany 31(2): 337-348.

Mitchell, J.D. \& Mori, S.A. 1987. The Cashew and Its Relatives (Anacardium: Anacardiaceae). Memoirs of the New York Botanical Garden 42: 1-76.

Mooers, A. Ø. 2007. The diversity of biodiversity. Nature 445: 717-718.

Moreira-Muñoz, A. 2007. The Austral floristic realm revisited. Journal of Biogeography 34: 1649-1660.

Mori, S. A. Silva, L. A. M. Lisboa, G. \& Coradin, L. 1989. Manual de manejo do herbário fanerogâmico. Ilhéus, Centro de Pesquisa do Cacau.

Morrone, J.J. 2001. Biogeografía de América Latina y el Caribe, Vol. 3. Manuales \& Tesis SEA, Zaragoza. 
Morrone, J.J. 2006. Biogeographic áreas and transition zones of Latin America and Caribbean Islands based on panbiogeographic and cladistic analyses of the entomofauna. Annual Review of Entomology 51: 467-494.

Muñoz, J.D. 1990. Anacardiaceae. In Flora del Paraguay. Conservatoire et Jardin botaniques de la Ville de Géneve; Missouri Botanical Garden, Saint Louis, p. 784.

Muñoz, J.D. 2000. 153. Anacardiaceae. In A.T. Hunkizer (ed.) Flora Fanerogamica Argentina. Proflora (Conicet), Cordoba, fasc. 65, p.1-28.

Nel, J.L., Richardson, D.M., Rouget, M., Mgidi, T.N., Mdzeke, N., Le Maitre, D.C., Wilgen, B.W., Schonegevel, L., Henderson, L. \& Neser, S. 2004. A proposed classification of invasive alien plant species in South Africa: towards prioritizing species and areas for management action. South Africa Journal of Science 100: 53-64.

Nie, Z., Sun, H., Meng, Y. \& Wen, J. 2009. Phylogenetic analysis of Toxicodendron (Anacardiaceae) and its biogeographic implications on the evolution of north temperate and tropical intercontinental disjunctions. Journal of Systematics and Evolution 47(5): 416-430.

Ocampo, F.C. 2008. Inventario y conservación de los escarabajos (Scarabaeoidea) de las zonas áridas del sur de América del Sur. Cuardernos de biodiversidad 26: 13-20.

Olson, D.M. \& Dinerstein, E. 2002. The global 200: priority ecoregions for global conservation. Annals of the Missouri Botanical Garden 89: 199-224.

Ortiz-Jaureguizar, E. \& Cladera, G.A. 2006. Paleoenvironmetal evolution of the southern South America during the Cenozoic. Journal of Arid Environmental 66: 498-532.

Overbeck, G.E., Müller, S.C., Fidelis, A., Pfadenhauer, J., Pillar, V.D., Blanco, C.C., Boldrini, I.I., Both, R. \& Forneck, E.D. 2007. Brazil'sneglected biome: The South Brazilian Campos. Perspectives in Plant Ecology, Evolution and Systematics 9: 101-116.

Pell, S.K. 2004. Molecular systematics of the cashew family (Anacardiaceae). Ph.D. dissertation. Baton Rouge: Lousiana State University.

Pell, S.K., Mitchell, J.D., Lowry, P.P., Randrianasolo, A. \& Urbatsch, L.E. 2008. Phylogenetic split of Malagasy and African taxa of Protorhus and Rhus (Anacardiaceae) based on cpDNA trnL-trnF and nrDNA ETS and ITS sequence data. Systematic Botany 33: 375-383. 
Pell, S.K., Mitchell, J.D., Miller, A.J. \& Lobova, T.A. 2011. Anacardiaceae. In K. Kubitzki (ed.) The families and genera of vascular plants. X. Flowering plants. Eudicots. Sapindales, Curcubitales, Myrtales. Springer, Berlin, p. 7-50.

Pennington, R.T., Quentin, C.B., Richardson, C. \& Richardson, J.A. 2004. Introduction and synthesis: plant phylogeny and the origin of major biomes. Philosophical Transactions of the Royal Society B 359: 1455-1464.

Radford, A.E. 1986. Fundamentals of plant systematics. Harper \& Row. New York.

Raven, P.H. \& Axelrod, D.I. 1974. Angiosperm biogeography and past continental movements. Annals of the Missouri Botanical Garden 61: 539-673.

Reitz, R. (ed.). 1985. Flora ilustrada catarinense. Itajaí, SC, Herbário Barbosa Rodrigues.

Rodrigues, D.M., Oliveira, J.M.S. \& Mariath, J.E.A. 2004. Comparação de desenvolvimento inicial do rudimento seminal em Schinus terebinthifolius Raddi e Schinus polygamous (Cav.) Cabr. (Anacardiaceae). Revista de Iniciação Científica da ULBRA 3:61-72.

Roig-Juñent, S., Domínguez, M.C., Flores, G.E. \& Mattoni, C. 2006. Biogeographic history of South American arid lands: A review from its arthropods using TASS analysis. Journal of Arid Environments 66: 404-420.

Romero, E.J. 1978. Paleoecologia y Paleofitogeografia de las tafofloras del Cenofitico de Argentina y areas vecinas. Ameghiniana 15: 209-227.

Romero, E.J. 1986. Paleogene phytogeography and climatology of South America. Annals of the Missouri Botanical Garden 73:449-461.

Romero, E.J. 1993. South America paleofloras. In Goldblatt, P. (ed.), Biological relationships between Africa and South America. Yale University Press, New Haven, CT, pp. 62-85.

Sanderson, M.J. 2002. Estimating absolute rates of molecular evolution and divergence times: A penalized likelihood approach. Molecular Biology and Evolution 19: 101-109.

Sanderson, M.J. 2003. r8s: inferring absolute rates of molecular evolution and divergence times in the absence of a molecular clock. Bioinformatics 19: 301302.

Santos, A.C.A., Rossato, M., Serafini, L.A., Bueno, M., Crippa, L.B., Sartori, V.C., Dellacasa, E. \& Moyna, P. 2010. Efeito fungicida dos óleos essenciais em Schinus molle L. e Schinus terebinthifolius Raddi, Anacardiaceae, do Rio Grande do Sul. Revista Brasileira de Farmacognosia 20(2): 154-159.

Schmitz, D.C., Simberloff, D., Hofstetter, R.H., Haller, W., Sutton, D. 1997. The ecological impact of nonindigenous species. In D. Simberloff, D.C., Schmitz, 
T.C., Brown (eds) Strangers in Paradise: Impact and Management of nonindigenous species in Florida. Island Press, Washington, D.C., p. 9-61.

Silva-Luz, C.L. \& Pirani, J.R. 2010. Anacardiaceae. In R.C. Forzza et al. (org.) Catálogo de plantas e fungos do Brasil. Rio de Janeiro: Jardim Botânico do Rio de Janeiro, v. 1, p. 599-602.

Silva-Luz, C.L. 2012. Anacardiaceae R. Br. na Flora Fanerogâmica do Estado de São Paulo. Dissertação de Mestrado, Universidade de São Paulo, São Paulo, 94 p.

Silva-Luz, C.L. \& Pirani, J.R. 2012. Anacardiaceae. In Lista de Espécies da Flora do Brasil. Jardim Botânico do Rio de Janeiro. (http://floradobrasil.jbrj.gov.br/2011/FB000044).

Simmons, M.P. 2004. Independence of alignment and tree search. Molecular Phylogenetics and Evolution 31: 874-879.

Smith, N.D. \& Turner, A.H. 2005. Morphology's role in phylogeny reconstruction: Perspectives from paleontology. Systematic Biology 54: 166-173.

Souza, C.R.G., Suguio, K., Oliveira, A.M.S. \& Oliveira, P.E. (eds.). 2005. Quaternário do Brasil. Ribeirão Preto: Holos Editora, 382 p.

Souza, V.C. \& Lorenzi, H. 2005. Botanica Sistemática: guia ilustrado para identificação das famílias de Angiospermas da flora brasileira, baseado em APG II. Instituto Plantarum de Estudos da Flora LTDA, Nova Odessa.

Stearn, W.T. 1992. Botanical Latin, history, grammar, syntax, terminology and vocabulary. 4th ed. Redwood Press, England. $546 \mathrm{p}$.

Steibel, P.E. \& Troiani, H.O. 2005. Morfologia foliar em cuatro especies de Schinus (Anacardiaceae) em distintas edades de las plantas. Boletín de la Sociedad Argentina de Botánica 40 (Supl.): 78-79.

Steibel, P.E. \& Troiani, H.O. 2008. La identidade de Schinus fasciculatus var. arenicola y rehabilitación de $S$. sinuatus (Anacardiaceae). Boletín de la Sociedad Argentina de Botánica 43(1-2): 157-166.

Swofford, D.L. 2002. PAUP*: Phylogenetic Analysis Using parcimony * and Other Methods. Version 4.0b10. Sinauer, Sunderland, USA.

Terrazas, T. 1994. Wood anatomy of the Anacardiaceae: ecological and phylogenetic interpretation. Ph.D. dissertation. Chapel Hill, NC: University of North Carolina.

Troncoso, A. \& Romero, E.J., 1998. Evolución de las comunidades florísticas en el extremo sur de Sudamérica durante el Cenofítico. In Fortunato, R. \& Bacigalupo, N. (eds.), Proceedings of the VI Congreso Latinoamericano de Botánica. Monographs in 
Systematic Botany from the Missouri Botanical Garden 68: 149-172.

Vogel, E.F. Seedlings of dicotyledons: structure, development, types. Descriptions of 150 woody Malesian taxa. Pudoc, Wageningen, the Netherlands, 465 p.

Weberling F. 1989. Morphology of flowers and inflorescences. Cambridge: Cambridge University Press.

Weeks, A., Daly, D.C. \& Simpson, B.B. 2005. Phylogenetic relationships and historical biogeography of the Burseraceae based on nuclear and chloroplast sequence data. Molecular Phylogenetics and Evolution 35: 85-101.

Wheeler, Q.D. 2004. Taxonomic triage and the poverty of phylogeny. Philosophical Transactions of the Royal Society of London B, 359: 571-583.

Wheeler, D.Q., Raven, P.H. \& Wilson, E.O. 2004. Taxonomy: Impediment or Expedient? Science 303: 285.

Wiens, J.J. 2004. The role of morphological data in phylogeny reconstruction: a reply to Scotland et al. (2003). Systematic Biology 53: 653-661.

Yi, T., Miller, A.J. \& Wen J. 2007. Phylogeny of Rhus (Anacardiaceae) based on sequences of nuclear Nia-i3 intron and Chloroplast TrnC-TrnD. Systematic Botany 32(2): 379-391.

Yi, T., Wen, J., Golan-Goldhirsh, A. \& Parfitt, D.E. 2008. Phylogenetics and reticulate evolution in Pistacia (Anacardiaceae). American Journal of Botany 95(2):241-251.

Yu, Y., Harris, A.J. \& He, X.J. 2010. S-DIVA (statistical dispersal-vicariance analysis): a tool for inferring biogeographic histories. Molecular Phylogenetics and Evolution 56: 848-850.

Yu, Y., Harris, A.J. \& He, X.J. 2011. RASP (Reconstruct Ancestral State in Phylogenies) 2.0 beta. Available at http://mnh.scu.edu.cn/soft/blog/RASP.

Zona, S., 2015. A correct gender of Schinus (Anacardiaceae). Phytotaxa 222(1): 7577.

Zuloaga, F.O. \& Morrone, O. (eds.). 1996. Catálogo de las plantas vasculares de la República Argentina. I. Pteridophyta, Gymnospermae y Angiospermae (Monocotyledoneae). Monographs in Systematic Botany from the Missouri Botanical Garden 60: 1-332.

Zuloaga, F.O. \& Morrone, O. (eds.). 1999. Catálogo de las plantas vasculares de la República Argentina. Dicotyledonae. Monographs in Systematic Botany from the Missouri Botanical Garden 74: 1-1246.

Zuloaga, F.O., Morrone, O. \& Beltrano, M.J. 2008. Catálogo de las plantas vasculares Del Cono Sur (Argentina, Sur de Brasil, Chile, Paraguay e Uruguay). Monographs in systematic Botany 107: 1-3486. 


\section{A novel phylogeny-based classification for Schinus L. (Anacardiaceae)}

\section{Abstract}

Schinus, a genus best known by its few cultivated and invasive species, is the largest genus of Anacardiaceae in southern South America. It is remarkably diverse compared to closely related genera, with approximately 42 species, most of which occur in several arid vegetation types and extending into Andean and Atlantic moist forests. The most comprehensive taxonomic revision of the genus dates to 1957, which recognized S. subg. Schinus and S. subg. Duvaua, the latter of which was further divided into two sections. Subsequent studies have highlighted morphological inconsistencies in this infrageneric classification, and species delimitation remains a challenge. Schinus has been poorly sampled in previous phylogenetic studies of Anacardiaceae, and thus any assumptions about its monophyly and relationships (particularly among its species and infrageneric categories) remain untested. We investigated the phylogenetic relationships of all Schinus species using nine nuclear and two plastid DNA sequence regions, most of them developed recently for Commiphora (Burseraceae). We used maximum parsimony, maximum likelihood, and Bayesian inference to infer relationships among all species. We also constructed a morphological dataset, including vegetative anatomical features, based on analysis of herbarium specimens and fresh material obtained through fieldwork, and compared these characters to hypotheses based on molecular evidence in order to: 1. achieve a better understanding of the relationships among its species and to related genera, 2 . identify morphological characters and putative synapomorphies for major clades, and 3. discuss hypotheses regarding the evolution of structural traits in the group. Our analyses strongly support the monophyly of Schinus, but also indicate that its infrageneric groups $S$. subg. Duvaua sect. Duvaua and $S$. subg. Duvaua sect. Pseudoduvaua are polyphyletic and have been defined using homoplastic characters. The phylogenetic relationships that emerged from our analyses include eight strongly supported lineages, (except for $S$. sect. Atlantica), but relationships among closely related species remain unclear in some clades. Ancestral state reconstructions demonstrate that some morphological and leaf-anatomical characters are valuable in characterizing some lineages, and may serve as potential synapomorphies to define these clades. By contrast, most of the traits that have 
traditionally been used to circumscribe groups in Schinus show high levels of homoplasy. In light of these results, we present a novel sectional classification of Schinus, an identification key for the sections and comments on the taxonomy and geographic distribution of each section. The eight monophyletic sections proposed here are recognized by a combination of character states associated with geographic distribution, corresponding to lineages that are mostly allopatric or at least ecologically distinct.

Keywords: eudicots, infrageneric categories, Duvaua, morphological traits, Pseudoduvaua, rosids, Sapindales

\section{Introduction}

Several systematic studies of the family Anacardiaceae have successfully used molecular data to build phylogenetic hypotheses (Al-Saghir, 2010; Miller et al., 2001; Nie et al., 2009; Pell et al., 2008; Weeks et al., 2014; Xie et al., 2014; Yi et al., $2004,2007,2008)$, but these data remain scarce for the South American members of this family. Schinus, the largest genus of Anacardiaceae in South America, has approximately 42 species restricted to southern region of the continent, plus two widespread (and invasive) species, S. areira L. and S. terebinthifolia Raddi. The genus is well delimited morphologically and is more diversified (in terms of species number and habitat range) than other closely related genera in the family, such as Mauria Kunth (10-15 spp.), Euroschinus Hook. f. (ca. 9 spp.), Thyrsodium Salzm. ex Benth. (6-7 spp.), Schinopsis Engl. (7 spp.), Amphipterygium Schiede ex Standl. (45 spp.), Astronium Jacq. (7 spp.), Lithrea Miers ex Hook. \& Arn. (3 spp.), Loxopterygium Hook. f. (3 spp.), Myracrodruon Allemão (2 spp.), and four monospecific genera: Ochoterenaea F.A. Barkley, Orthopterygium Hemsl., Cardenasiodendron F.A. Barkley, and Apterokarpos Rizzini (Pell et al., 2011; Weeks et al., 2014). The best known species of Schinus can be recognized by their pinnately compound leaves with a winged rachis and paniculate inflorescences, but the majority of species have simple leaves and pseudoracemose inflorescences, along with branches terminating in a thorny apex. Flower and fruit morphologies are very uniform across the genus, in which the perianth is mostly pentamerous (sometimes tetramerous), the androecium is diplostemonous in two whorls distinctly unequal in length. The plants are dioecious, with staminate flowers that bear a small pistillode, and pistillate flowers that have reduced staminodes. The fruits of Schinus are usually globose drupes, with a thin, lustrous exocarp that varies from light purple to dark red, and separates easily from the resinous mesocarp at maturity. The 
leaves and fruits produce a distinct mango-like smell, and the pink-red fruits of $S$. molle and S. terebinthifolia are commony sold as "pink peppercorns" and often blended with commercial pepper. Despite the relative uniformity in morphology, species of Schinus can be found throughout a great diversity of habitats, such as Patagonia, Chaco, Monte, Seasonally Dry Tropical Forest, pre-Puna, Yungas, Tucumán-Bolivian Forest, Chilean Temperate Forest, Atlantic Forest, and Mediterranean Chile. The genus is distributed along the Andes in Chile, Argentina, Bolivia, and Peru, in both the inter-Andean valleys and cloud forests, and at low altitudes from southeastern to northeastern Argentina, extending also into Uruguay, Paraguay, and southern Brazil. A few endemic species also occur on the sclerophyll forests of Chile. The distribution of its species in many southern South American vegetation types, especially in the Andes, suggests that Schinus might serve as a promising model for studies of diversification and biogeography.

Schinus was described by Linnaeus (1753), who considered its pinnate leaves as the distinguishing feature of the genus. Later, Cavanilles (1795) described Amyris polygama Cav., a taxon with simple leaves that was subsequently transferred to Schinus by de Candolle (1825), thereby expanding the generic circumscription. In his revision of the genus, Barkley (1957) recognized 28 species and 17 varieties classified in two subgenera. According to Barkley (1957), Schinus subgenus Schinus (as subg. Euschinus) includes plants with pinnately compound leaves and paniculate inflorescences, whereas the species of Schinus subgenus Duvaua (Kunth) F.A. Barkley bear simple leaves and pseudoracemes. In subgenus Duvaua, Barkley (1957) further recognized two sections, Pseudoduvaua and Duvaua (as sect. Euduvaua), the latter of which included several taxa of disputed delimitation. For example, Cabrera (1938) and Fleig (1989) considered many published binomials of this section as synonyms under S. polygama (Cav.) Cabrera (S. subg. Duvaua sect. Duvaua), while Barkley's (1957) treatment of the section recognized about 15 distinct species and 5 varieties, based mainly on leaf morphology. The infrageneric categories created by Barkley were proposed to suit the simple-leaved species in Schinus subgen. Duvaua, but there is some degree of overlap with regard to the traditional characters used in his infrageneric classification, suggesting that these characters are not entirely consistent (Fleig 1987). For instance, S. pearcei Engl. (S. subg. Schinus) has paniculate inflorescences but dissected leaves (intermediate between simple and compound leaves). Therefore, a phylogenetic study of Schinus using both morphological and molecular data can be useful in providing insights into understanding the taxonomy and phylogenetic relationship among its species. It can also help to identify 
taxonomically important morphological traits that have not been considered before. To date, Schinus has been poorly sampled in phylogenetic studies, and thus any assumptions about its monophyly and relationships among its species and infrageneric categories remain untested. In previous phylogenetic studies of Anacardiaceae (Al-Saghir, 2010; Miller et al., 2001; Nie et al., 2009; Pell et al., 2008; Xie et al., 2014; Yi et al., 2004, 2007, 2008), Schinus was not the target group, and as such had been sampled only as an outgroup. More recently, five Schinus taxa were sampled in a broader study of Anacardiaceae and Burseraceae (Weeks et al., 2014), and this study provided a very preliminary confirmation of the monophyly of the genus. Here, we present a phylogenetic hypothesis of Schinus using a much broader sampling of 47 taxa, which also includes several varieties, allowing us to test more fully the monophyly of the genus and to examine infrageneric categories, as well as to identify possible morphological traits that can be used to support the recognition of particular clades.

\section{Material and methods}

\subsection{Sampling, DNA extraction, amplification and sequencing}

Our study included DNA sequences from a total of 129 specimens. Within Schinus, we sampled from 84 specimens (table 1), representing both subgenera recognized by Barkley (1957), including 39 samples from nearly all of the 28 species and 17 varieties of Schinus, with the exception only of $S$. gracilipes I.M.Johnston var. pilosa F.A.Barkley, S. patagonica (Phil.) I.M.Johnst. var. crenuloides (F.A. Barkley) F.A.Barkley, $S$. weinmanniifolia Engl. var. riedeliana Engl., $S$. weinmanniifolia Engl. var. dubia F.A.Barkely and S. terebinthifolia Raddi var. raddiana Engl. as well as three species described later (i.e., S. roigii Ruiz-Leal \& Cabrera, S. sinuata Engl., and S. meyeri F.A.Barkley). Although Barkley considered S. johnstonii F.A.Barkley and S. fasciculata (Griseb.) I.M.Jonhston var. arenicola (Haumann) F.A.Barkley to be distinct taxa, we here treat them as the same taxon based on the study of Steibel and Troiani (2008), for a total number of 44 taxa (instead of 45). We also included specimens of five potentially new species, yielding a total of 47 Schinus taxa in our study. The choice of the outgroup used in this study was based on Weeks et al. (2014), in which Schinus and 13 other genera (i.e. Amphipterygium Schiede ex Standl., Apterokarpos Rizzini, Astronium Jacq., Cardenasiodendron F.A.Barkley, Lithrea Miers ex Hook. \& Arn., Loxopterygium Hook.f., Mauria Kunth, Myracrodruon Allemão, Ochoterenaea F.A.Barkley, Orthopterygium Hemsl., Schinopsis Engl., Thyrsodium Salzm. ex Benth., and Euroschinus Hook.f.) form a clade they labeled "Anacardioideae 2". Outgroup 
sequences (table 2) were taken from previously published studies and retrieved from GenBank (for 17 specimens), or obtained during this study (for 31 specimens). Toxicodendron radicans (L.) Kuntze is the most distantly related outgroup and was used to root the trees resulting from our phylogenetic analyses when possible. Otherwise, Lithrea molleoides (Vell.) Engl. or L. brasiliensis Marchand was used to root the trees when sequences of Toxicodendron radicans were not available, especially for those individual analyses using molecular markers from Gostel et al. (2015).

Genomic DNA was extracted from both silica-gel dried and herbarium material. Extractions of total DNA were performed with DNeasy Plant Mini kit (QIAGEN Inc.) using a modified version of Alexander et al. (2007), in which silicagel material was incubated at $65^{\circ} \mathrm{C}$ for $60 \mathrm{~min}$, and herbarium material was incubated at $42^{\circ} \mathrm{C}$ for $12-24$ hours. After adding $130 \mu \mathrm{L} 3 M$ potassium acetate $(\mathrm{pH}$ 4.7), tubes were inverted several times and incubated on ice for $30 \mathrm{~min}$.

We amplified sequence regions that have been useful for phylogeny reconstruction in other genera of Anacardiaceae, including Pistacia L., Toxicondendron Mill., Rhus L., and Protorhus Engl. (Miller et al., 2001; Nie et al., 2009; Pell et al., 2008; Yi et al., 2004, 2008). This included the external and internal transcribed spacers (ETS, ITS) of the nuclear ribosomal genes (rDNA), the chloroplast intergenic spacer (trnL-trnF region), and the chloroplast rps16 intron. Amplification of ETS employed primers Bur-ETS1F and 18S-IGS (Baldwin and Markos, 1998; Weeks et al., 2005) at $95^{\circ} \mathrm{C}$ for $2 \mathrm{~min}$, followed by 40 cycles of $94^{\circ} \mathrm{C}$ for $30 \mathrm{sec}, 52^{\circ} \mathrm{C}$ for $60 \mathrm{sec}$, and $72^{\circ} \mathrm{C}$ for $50 \mathrm{sec}$, after which a final extension step $\left(72^{\circ} \mathrm{C}\right.$ for $4 \mathrm{~min}$ ) was completed. ITS was amplified using primers ITS5A (Stanford et al. 2000) and 26S-25R, designed by K. Wurdack (Pell et al. 2008, pers. comm.) with the same thermocycler program as ETS. We also tested the program described by Mogni et al. (2016), which was modified from Pell (2004) [97 ${ }^{\circ} \mathrm{C}, 50 \mathrm{sec}$; 35 cycles of $\left(97^{\circ} \mathrm{C}, 50 \mathrm{sec} ; 53^{\circ} \mathrm{C}, 50 \mathrm{sec} ; 72^{\circ} \mathrm{C}, 1 \mathrm{~min} 50 \mathrm{sec}\right) 72^{\circ} \mathrm{C}, 7 \mathrm{~min}$ ] and proved successful in amplifying some ITS sequences. The rps16 intron was amplified with primers rps $16 \mathrm{~F}$ and rps19R (Oxelman et al., 1997) at $95^{\circ} \mathrm{C}$ for $2 \mathrm{~min}$, followed by 40 cycles of $94^{\circ} \mathrm{C}$ for $30 \mathrm{sec}, 56^{\circ} \mathrm{C}$ for $30 \mathrm{sec}$, and $72^{\circ} \mathrm{C}$ for $80 \mathrm{sec}$, and a final extension step $\left(72^{\circ} \mathrm{C}\right.$ for $\left.4 \mathrm{~min}\right)$. The $t r n L-t r n F$ region was amplified with primers "a" and " $\mathrm{f}$ " (Taberlet et al., 1991) at $95^{\circ} \mathrm{C}$ for $2 \mathrm{~min}$, followed by 40 cycles of $94^{\circ} \mathrm{C}$ for 30 sec, $50^{\circ} \mathrm{C}$ for $30 \mathrm{sec}$, and $72^{\circ} \mathrm{C}$ for $80 \mathrm{sec}$, and a final extension step $\left(72^{\circ} \mathrm{C}\right.$ for 4 min). Since all of these regions were alignable across the targeted taxa and useful for investigating phylogeny at the familial and generic levels (Weeks et al., 2014), we also decided to test other primers to ensure sufficient variation at the 
interspecific level. For this, we used the study of Gostel et al. (2015), which describes the development and validation of a novel set of 91 nuclear markers for PCR-based target enrichment for Commiphora Jacq. (Burseraceae). Subsequently, Collins et al. (2016) demonstrated that customized primers for Bursera Jacq. ex L. can amplify DNA products in a range of Sapindalean taxa. For instance, 34 of the 91 primers were successfully amplified for Schinus. Of these, we used seven sets of primer pairs (AT2G04620-F and AT2G04620-R; AT2G20790-F and AT2G20790-R; AT3G26580-F and AT3G26580-R; AT2G44760-F and AT2G44760-R; AT2G47760$F$ and AT2G47760-R; AT5G48790-F and AT5G48790-R; AT1G63160-F and AT1G63160-R) that successfully amplified nuclear regions from Schinus and related genera. The thermocycler program used for these markers followed Gostel et al. (2015), and information regarding primer sequences is provided in table 3. Amplification of the selected plastid regions and those from Gostel et al. (2015) were performed in $22 \mu \mathrm{L}$ reactions with $3 \mu \mathrm{L}$ of unquantified total DNA, $1.1 \mu \mathrm{L}$ of each primers $(5 \mu \mathrm{M}), 1.1 \mu \mathrm{L}$ of spermidine $(4 \mathrm{mM}), 4.7 \mu \mathrm{L}$ of water, and $11 \mu \mathrm{L}$ of EconoTaq® PLUS GREEN 2X Master Mix (Lucigen). The ETS and ITS regions were amplified in $16 \mu \mathrm{L}$ reactions with, $2 \mu \mathrm{L}$ of unquantified DNA, $0.8 \mu \mathrm{L}$ of each primer $(5 \mu \mathrm{M}), 0.8 \mu \mathrm{L}$ of spermidine $(4 \mathrm{mM}), 3.6 \mu \mathrm{L}$ of water, and $8 \mu \mathrm{L}$ of the same EconoTaq® Master Mix. For samples that did not amplify, we increased the concentration of template DNA. Cycle sequencing was performed with the same forward and reverse primers used for amplification at the high-throughput sequencing services at the University of Washington (Seattle, WA, USA) and Macrogen Corp. (New York, NY, USA).

\subsection{Alignment and Phylogenetic analyses}

DNA sequence fragments were assembled, trimmed, and edited using Geneious 9.1.2 (Biomatters). Alignment of sequences across samples was conducted using MUSCLE and minor adjustments were made manually in Geneious. Nucleotide sequences newly generated during this study were combined with previously published sequences available from GenBank. The published ETS sequence of Loxopterygium huasango Spruce ex Engl. has a unique insertion between aligned basepair positions 337 to 359 . Moreover, the dataset contained no variable characters between bp postions 360 and the end of the fragment (bp 390). Therefore, to avoid introducing an excess of missing data resulting from the large insertion, the portion of the alignment that included both the 22-bp indel and the downstream invariant region was removed, and thus the ETS fragment used for phylogenetic analysis was $336 \mathrm{bp}$ instead of $390 \mathrm{bp}$. Among the AT3G26580 
sequences, there were some regions that we could not confidently align, and we therefore removed these ambiguous blocks of data (see Talavera and Castresana, 2007). To search for improvements in the quality of the alignments, we ran Gblocks 0.91b (Castresana, 2000) using its web server, with a more stringent parameter (b1= 29; b2= 47; b3=4; b4=10; b5= "not allowing gap positions"). The Gblocks alignment of AT3G26580 sequences generated was nearly $30 \mathrm{bp}$ shorter (481 bp vs. $510 \mathrm{bp}$ ) than the original one and was therefore used for phylogenetic analysis.

The eleven single-gene alignments were independently subjected to phylogenetic analyses in MrBayes v.3.2.1 (Huelsenbeck and Ronquist, 2001; Ronquist and Huelsenbeck, 2003) and each locus was assigned its partition-specific model parameters. DNA substitution models were estimated using jModeltest 2.1.7 (Darriba et al., 2012) under the Akaike information criterion (table 3). The Bayesian analyses incorporated two independent runs, each with four Markov chains, starting from random trees, proceeded for 20 million generations, and sampled every 2000 generations. The MCMC sampling was considered sufficient when priors reached the convergence with the effective sampling size (ESS) usually higher than 200 , as verified in Tracer v1.6 (Rambaut and Drummond, 2007). Burn-in for each run was determined using convergence diagnostics, and the generations sampled prior to stationarity were eliminated. The remaining trees were used to construct a majorityrule consensus from MrBayes and to derive the associated Bayesian posterior probabilities (BPP). Phylogenetic trees obtained from each single-gene were inspected visually for well supported (posterior probability, PP $\geq 0.95$ ) topological differences prior to analyzing our datasets in combined analyses. Because there were no significant incongruences among the single-gene trees, all datasets were combined for further analyses. Phylogenetic analyses were completed using the facilities at the CIPRES Science Gateway v.3.3 (Miller et al. 2010), portal in SanDiego, USA (http://www.phylo.org/).

The combined dataset was analyzed phylogenetically employing maximum parsimony, maximum likelihood and Bayesian inference. Maximum parsimony (MP) analyses were conducted in PAUP version 4.0b10 (Swofford, 2003) using a reverse constraint approach (Catalán et al., 1997). Initial heuristic searches used 50 random addition replicates, nearest-neighbor-interchange (NNI) branch swapping, MULTREES on and equal weighting of all characters. The strict consensus of trees from this initial search was applied as a reverse constraint in a second search that used 10,000 random addition replicates, TBR branch swapping and MULTREES off. This process was repeated using the strict consensus of all previous searches until no shorter trees were recovered; if shorter trees were identified, subsequent 
searches used a consensus of only these trees. The strict consensus of all the shortest trees found by this procedure was assumed to represent the MP tree. MP bootstrapping (Felsenstein, 1985) was conducted with 1000 replicates using random taxon addition (a single random-addition search per bootstrap replicate), TBR branch swapping, and MULTREES on. Maximum likelihood (ML) analyses were conducted with RAxML v.8.0.3 (Stamatakis, 2014). These analyses used general time reversible (GTR) substitution models with a gamma model of rate heterogeneity. Clade support was estimated using 1000 rapid bootstrap replicates (Stamatakis et al., 2008). The Bayesian inference (BI) analysis was performed using Markov Chain Monte Carlo (MCMC) sampling in BEAST v1.8.3 (Drummond et al., 2012), assigning the partition-specific model parameters to each locus. DNA substitution models were estimated using PartitionFinder (Lanfear et al., 2012) to choose an appropriate partitioning scheme and the model of molecular evolution for each alignment using AIC model selection and greedy heuristic algorithm to search for partitioning schemes. Following the best scheme chosen by PartitionFinder, we unlinked nine loci and each of them was assigned to one independent DNA substitution model and two loci (i.e. AT2G47760-F and AT2G47760-R; AT1G63160$F$ and AT1G63160-R) were linked and assigned to the same model of molecular evolution (table 3 ). According to analysis performed in ClockstaR (Duchene et al., 2014), a method that estimates the optimal number of partitions representing the smallest number of relaxed-clock models that are needed to describe the data, all clock models were linked in BEAST. A birth-death speciation process (Gernhard, 2008) was specified as a tree prior where death-rate and growth-rate parameters were sampled from an Exp (1) prior distribution. Rate heterogeneity among lineages was modeled using an uncorrelated lognormal relaxed molecular clock (Drummond et al., 2006) with a mean sampled from an Exp (0.33) prior distribution. The MCMC was run for 30 million generations, sampling every 2,000 generations. Convergence was assessed using Tracer v1.6, and runs were considered satisfactory with ESS values greater than 200. Burn-in for each run was determined using convergence diagnostics, and generations sampled prior to stationarity were eliminated. The information from the sample of trees produced by BEAST was summarized with TreeAnnotator v1.8.3 (Drummond et al., 2012). The output trees were visualized and edited in FigTree v1.4.2 (Rambaut 2010).

\subsection{Ancestral state reconstruction of morphological characters}

The characters traditionally used in the infrageneric circumscription of Schinus were thorny branches, leaf division, and inflorescence (Barkley, 1957). 
During the development of this study, however, we observed 12 additional morphological features that seem to show promise for the investigation of character evolution in Schinus, yielding a total of 15 morphological characters scored (table 4), of which 11 correspond to the macromorphological features and four to leaf anatomical characters. The goal of this reconstruction was to identify putative synapomorphies or character combinations that might be used to recognize well supported clades in Schinus. The macromorphological characters were scored based on analysis of dried specimens from the following herbaria: BA, BAA, BHCB, CONC, CTES, FCQ, FLOR, GH, HBR, ICN, LP, LPB, MBM, MCNS, MO, MOL, MVFA, MVM, NY, PEL, PY, RB, SGO, SP, SPF, SI, US and USM (abbreviations follow Index Herbariorum). For the study of leaf anatomy, 21 Schinus taxa and two outgroup species were sampled (see table 5). This sampling accounts for only half of the species in Schinus, but is highly representative of the genus, with two or more species from each of the major lineages. The samples were obtained from fixed material or from dried specimens. Vegetative branches were fixed in formalin-acetic acid-alcohol (FAA) for 24 hours and stored in $70 \%$ ethyl alcohol. Subsequently, fragments from the median portion of the leaf or leaflet blade and the median portion of petiole were isolated, dehydrated in an ascending butyl series, and embedded in paraffin (Johansen, 1940). The material was sectioned transversely using a rotatory microtome and the sections were stained with astra-blue and safranin (Gerlach, 1984). The slides were mounted in synthetic resin and photographed under a Leica DMLB light microscope. The preparation of leaf or leaflet blade fragments or median portion of petiole from dried specimens followed the protocol of rehydration outlined in Smith and Smith (1942). Subsequently, these fragments were dehydrated in a graded series of alcohol and embedded in methacrylate (Gerrits, 1991). Transverse and longitudinal sections were obtained using a rotatory microtome and then stained with toluidine blue (O'Brien et al., 1964). A parsimony reconstruction was performed in Mesquite 3.04 (Maddison and Maddison, 2014) in which all characters were treated as unordered and equally weighted. Species polymorphic for a given character were scored with all applicable states for that character. The Bayesian tree based on the combined sequence dataset was used as the standard tree topology (see Fig. 1), but with multiple terminals representing a single species reduced to one. For eleven macromorphological character reconstructions, we used a phylogenetic tree with 42 terminals. For the leaf anatomy reconstructions, the tree topology had 23 terminals which correspond to the specimens sampled in the anatomical study (see table 5). In the attempt to avoid large amounts of missing 
Table 1. Schinus studied, voucher information and GenBank accession numbers. GenBank's sequence is from Weeks et al. (2014) publication. Letter "N" represents new sequences generated during this study.

\begin{tabular}{|c|c|c|c|c|c|c|c|c|c|c|c|c|}
\hline Taxa & Voucher & ETS & ITS & rps16 & trnL-trnF & 04620 & 20790 & 26580 & 44760 & 47760 & 48790 & 63160 \\
\hline Schinus areira & Silva-Luz 245 (SPF) & $\mathrm{N}$ & - & $\mathrm{N}$ & $\mathrm{N}$ & - & $\mathrm{N}$ & $\mathrm{N}$ & $\mathrm{N}$ & $\mathrm{N}$ & $\mathrm{N}$ & $\mathrm{N}$ \\
\hline Schinus areira & Silva-Luz 289 (SPF) & - & $\mathrm{N}$ & - & - & $\mathrm{N}$ & - & - & $\mathrm{N}$ & $\mathrm{N}$ & - & - \\
\hline Schinus areira & Silva-Luz 291 (SPF) & $\mathrm{N}$ & - & $\mathrm{N}$ & $\mathrm{N}$ & $\mathrm{N}$ & - & $\mathrm{N}$ & $\mathrm{N}$ & $\mathrm{N}$ & - & - \\
\hline Schinus areira & Silva-Luz 335 (SPF) & $\mathrm{N}$ & $\mathrm{N}$ & $\mathrm{N}$ & $\mathrm{N}$ & - & $\mathrm{N}$ & $\mathrm{N}$ & N & N & $\mathrm{N}$ & - \\
\hline Schinus areira & Silva-Luz 338 (SPF) & $\mathrm{N}$ & $\mathrm{N}$ & $\mathrm{N}$ & $\mathrm{N}$ & - & $\mathrm{N}$ & N & N & $N$ & N & $\mathrm{N}$ \\
\hline Schinus bumelioides & Silva-Luz 277 (SPF) & $\mathrm{N}$ & $\mathrm{N}$ & $\mathrm{N}$ & $\mathrm{N}$ & $\mathrm{N}$ & $\mathrm{N}$ & $\mathrm{N}$ & $\mathrm{N}$ & $\mathrm{N}$ & $\mathrm{N}$ & $\mathrm{N}$ \\
\hline Schinus bumelioides & Silva-Luz 282 (SPF) & $\mathrm{N}$ & $\mathrm{N}$ & $\mathrm{N}$ & $\mathrm{N}$ & $N$ & $\mathrm{~N}$ & $N$ & N & $N$ & - & - \\
\hline Schinus ramboi & Silva-Luz 161 (SPF) & $\mathrm{N}$ & $\mathrm{N}$ & $\mathrm{N}$ & $\mathrm{N}$ & $\mathrm{N}$ & $\mathrm{N}$ & $\mathrm{N}$ & - & $\mathrm{N}$ & $\mathrm{N}$ & $\mathrm{N}$ \\
\hline Schinus engleri & Silva-Luz 259 (SPF) & $\mathrm{N}$ & $\mathrm{N}$ & $\mathrm{N}$ & $\mathrm{N}$ & $\mathrm{N}$ & $\mathrm{N}$ & - & $\mathrm{N}$ & $\mathrm{N}$ & - & - \\
\hline S. engleri var. uruguayensis & Silva-Luz 217 (SPF) & $\mathrm{N}$ & $\mathrm{N}$ & $\mathrm{N}$ & $\mathrm{N}$ & $\mathrm{N}$ & - & N & $\mathrm{N}$ & N & - & N \\
\hline S. engleri var. uruguayensis & Silva-Luz 221 (SPF) & $\mathrm{N}$ & $\mathrm{N}$ & $\mathrm{N}$ & $\mathrm{N}$ & $\mathrm{N}$ & $\mathrm{N}$ & - & - & $\mathrm{N}$ & - & - \\
\hline Schinus fasciculata & Degen 3254 (MO) & $\mathrm{N}$ & - & - & - & N & - & - & - & - & - & - \\
\hline Schinus ferox & Silva-Luz 262 (SPF) & $\mathrm{N}$ & $\mathrm{N}$ & $\mathrm{N}$ & $\mathrm{N}$ & - & $\mathrm{N}$ & - & - & - & $\mathrm{N}$ & $\mathrm{N}$ \\
\hline Schinus ferox & Silva-Luz 333 (SPF) & $\mathrm{N}$ & $\mathrm{N}$ & $\mathrm{N}$ & $\mathrm{N}$ & $\mathrm{N}$ & N & N & - & N & $\mathrm{N}$ & - \\
\hline Schinus gracilipes & Bricker $182(\mathrm{NY})$ & $\mathrm{N}$ & - & - & - & - & - & - & - & - & - & - \\
\hline Schinus gracilipes & Pell 1008 (BKL) & KP055304 & $\mathrm{N}$ & - & - & N & $\mathrm{N}$ & N & N & N & - & - \\
\hline Schinus johnstonii & Silva-Luz 269 (SPF) & $\mathrm{N}$ & $\mathrm{N}$ & $\mathrm{N}$ & $\mathrm{N}$ & $\mathrm{N}$ & - & N & N & N & - & - \\
\hline Schinus latifolia & Silva-Luz 187 (SPF) & $\mathrm{N}$ & $\mathrm{N}$ & $\mathrm{N}$ & $\mathrm{N}$ & $\mathrm{N}$ & $\mathrm{N}$ & $\mathrm{N}$ & N & $\mathrm{N}$ & - & $\mathrm{N}$ \\
\hline Schinus latifolia & Silva-Luz 190 (SPF) & $\mathrm{N}$ & $\mathrm{N}$ & $\mathrm{N}$ & $\mathrm{N}$ & $\mathrm{N}$ & $\mathrm{N}$ & $\mathrm{N}$ & $\mathrm{N}$ & $\mathrm{N}$ & - & - \\
\hline Schinus lentiscifolia & Silva-Luz 220 (SPF) & $\mathrm{N}$ & $\mathrm{N}$ & $\mathrm{N}$ & $\mathrm{N}$ & $\mathrm{N}$ & $\mathrm{N}$ & N & N & $\mathrm{N}$ & N & - \\
\hline Schinus lentiscifolia & Silva-Luz 257 (SPF) & - & $\mathrm{N}$ & $\mathrm{N}$ & $\mathrm{N}$ & $\mathrm{N}$ & $\mathrm{N}$ & - & N & $\mathrm{N}$ & - & $\mathrm{N}$ \\
\hline Schinus lentiscifolia & Silva-Luz 258 (SPF) & $\mathrm{N}$ & - & - & - & $\mathrm{N}$ & $\mathrm{N}$ & - & $\mathrm{N}$ & $\mathrm{N}$ & - & $\mathrm{N}$ \\
\hline Schinus longifolia & Silva-Luz 214 (SPF) & $\mathrm{N}$ & N & $\mathrm{N}$ & $\mathrm{N}$ & $\mathrm{N}$ & $N$ & $\mathrm{~N}$ & $\mathrm{~N}$ & $\mathrm{~N}$ & - & - \\
\hline Schinus longifolia & Silva-Luz 331 (SPF) & N & $\mathrm{N}$ & $\mathrm{N}$ & $\mathrm{N}$ & $\mathrm{N}$ & - & $\mathrm{N}$ & $\mathrm{N}$ & $\mathrm{N}$ & N & - \\
\hline S. longifolia var. paraguariensis & Silva-Luz 312 (SPF) & $\mathrm{N}$ & $\mathrm{N}$ & $\mathrm{N}$ & $\mathrm{N}$ & $\mathrm{N}$ & $\mathrm{N}$ & - & N & $\mathrm{N}$ & - & - \\
\hline Schinus marchandii & Silva-Luz 272 (SPF) & $\mathrm{N}$ & $\mathrm{N}$ & $\mathrm{N}$ & $\mathrm{N}$ & - & $\mathrm{N}$ & $\mathrm{N}$ & - & - & - & - \\
\hline Schinus meyeri & Gallegos 305 (LPB) & $\mathrm{N}$ & - & - & - & - & $\mathrm{N}$ & - & - & - & - & - \\
\hline
\end{tabular}


Table 1. (continued)

\begin{tabular}{|c|c|c|c|c|c|c|c|c|c|c|c|c|}
\hline Taxa & Voucher & ETS & ITS & rps16 & trnL-trnF & 04620 & 20790 & 26580 & 44760 & 47760 & 48790 & 63160 \\
\hline Schinus microphylla & Silva-Luz 255 (SPF) & $\mathrm{N}$ & $\mathrm{N}$ & $\mathrm{N}$ & $\mathrm{N}$ & - & $\mathrm{N}$ & - & $\mathrm{N}$ & $\mathrm{N}$ & - & - \\
\hline Schinus microphylla & Silva-Luz 334 (SPF) & N & $\mathrm{N}$ & $\mathrm{N}$ & N & $\mathrm{N}$ & $\mathrm{N}$ & N & $\mathrm{N}$ & N & - & $\mathrm{N}$ \\
\hline Schinus microphylla & Silva-Luz 337 (SPF) & $\mathrm{N}$ & $\mathrm{N}$ & $\mathrm{N}$ & $\mathrm{N}$ & $\mathrm{N}$ & - & $\mathrm{N}$ & $\mathrm{N}$ & $\mathrm{N}$ & $\mathrm{N}$ & - \\
\hline Schinus molle & Calió 244 (UEC) & N & $\mathrm{N}$ & $\mathrm{N}$ & N & $\mathrm{N}$ & $\mathrm{N}$ & $\mathrm{N}$ & $\mathrm{N}$ & - & - & - \\
\hline Schinus molle & Silva-Luz 347 (SPF) & N & $\mathrm{N}$ & $\mathrm{N}$ & N & $\mathrm{N}$ & $N$ & N & N & - & - & - \\
\hline Schinus montana & Barkley 21 (NY) & N & - & N & - & $\mathrm{N}$ & $N$ & N & N & N & N & - \\
\hline Schinus montana & Silva-Luz 184 (SPF) & N & $\mathrm{N}$ & $\mathrm{N}$ & N & - & - & N & N & N & N & - \\
\hline Schinus montana & Silva-Luz 193 (SPF) & $\mathrm{N}$ & $\mathrm{N}$ & $\mathrm{N}$ & N & $\mathrm{N}$ & $\mathrm{N}$ & $\mathrm{N}$ & $\mathrm{N}$ & $\mathrm{N}$ & N & N \\
\hline Schinus montana & Silva-Luz 194 (SPF) & $\mathrm{N}$ & $\mathrm{N}$ & $\mathrm{N}$ & $\mathrm{N}$ & $\mathrm{N}$ & $\mathrm{N}$ & $\mathrm{N}$ & $\mathrm{N}$ & $\mathrm{N}$ & $\mathrm{N}$ & - \\
\hline Schinus myrtifolia & Silva-Luz 292 (SPF) & $\mathrm{N}$ & $\mathrm{N}$ & $\mathrm{N}$ & N & $\mathrm{N}$ & $\mathrm{N}$ & $\mathrm{N}$ & $\mathrm{N}$ & $\mathrm{N}$ & $\mathrm{N}$ & - \\
\hline Schinus myrtifolia & Silva-Luz 324 (SPF) & $\mathrm{N}$ & $\mathrm{N}$ & $\mathrm{N}$ & N & $\mathrm{N}$ & $\mathrm{N}$ & - & $\mathrm{N}$ & $\mathrm{N}$ & - & - \\
\hline Schinus myrtifolia & Silva-Luz 326 (SPF) & $\mathrm{N}$ & $\mathrm{N}$ & $\mathrm{N}$ & $\mathrm{N}$ & $\mathrm{N}$ & $\mathrm{N}$ & $\mathrm{N}$ & $\mathrm{N}$ & $\mathrm{N}$ & $\mathrm{N}$ & - \\
\hline Schinus odonellii & Silva-Luz 274 (SPF) & N & $\mathrm{N}$ & N & N & $\mathrm{N}$ & $N$ & N & N & N & - & - \\
\hline Schinus odonelli & Silva-Luz 275 (SPF) & $\mathrm{N}$ & $\mathrm{N}$ & $\mathrm{N}$ & $\mathrm{N}$ & $\mathrm{N}$ & $\mathrm{N}$ & $\mathrm{N}$ & $\mathrm{N}$ & $\mathrm{N}$ & - & - \\
\hline Schinus patagonica & Silva-Luz 201 (SPF) & N & $\mathrm{N}$ & $\mathrm{N}$ & N & N & N & N & N & N & N & N \\
\hline Schinus patagonica & Fortunato 5241 (NY) & N & - & - & N & - & $\mathrm{N}$ & - & - & - & - & - \\
\hline Schinus pearcei & Silva-Luz 256 (SPF) & $\mathrm{N}$ & $\mathrm{N}$ & $\mathrm{N}$ & $\mathrm{N}$ & $\mathrm{N}$ & - & $\mathrm{N}$ & N & $\mathrm{N}$ & - & - \\
\hline Schinus pearcei & Solomon 15709 (NY) & $\mathrm{N}$ & $\mathrm{N}$ & $\mathrm{N}$ & $\mathrm{N}$ & $\mathrm{N}$ & $\mathrm{N}$ & $\mathrm{N}$ & $\mathrm{N}$ & $\mathrm{N}$ & - & - \\
\hline Schinus pilifera & Silva-Luz 230 (SPF) & N & $\mathrm{N}$ & $\mathrm{N}$ & N & $\mathrm{N}$ & $\mathrm{N}$ & $\mathrm{N}$ & $\mathrm{N}$ & N & N & N \\
\hline Schinus pilifera & Silva-Luz 239 (SPF) & N & $\mathrm{N}$ & $\mathrm{N}$ & N & $\mathrm{N}$ & $\mathrm{N}$ & $\mathrm{N}$ & N & N & - & N \\
\hline Schinus pilifera & Silva-Luz 240 (SPF) & $\mathrm{N}$ & $\mathrm{N}$ & $\mathrm{N}$ & $\mathrm{N}$ & $\mathrm{N}$ & - & $\mathrm{N}$ & $\mathrm{N}$ & - & - & - \\
\hline Schinus pilifera & Silva-Luz 278 (SPF) & $\mathrm{N}$ & $\mathrm{N}$ & $\mathrm{N}$ & $\mathrm{N}$ & $\mathrm{N}$ & $\mathrm{N}$ & - & $\mathrm{N}$ & $\mathrm{N}$ & N & - \\
\hline Schinus pilifera & Silva-Luz 287 (SPF) & $\mathrm{N}$ & $\mathrm{N}$ & $\mathrm{N}$ & $\mathrm{N}$ & $\mathrm{N}$ & $\mathrm{N}$ & $\mathrm{N}$ & $\mathrm{N}$ & $\mathrm{N}$ & - & - \\
\hline Schinus pilifera & Silva-Luz 328 (SPF) & N & $\mathrm{N}$ & $\mathrm{N}$ & N & $\mathrm{N}$ & $\mathrm{N}$ & $\mathrm{N}$ & N & N & - & N \\
\hline Schinus pilifera var. boliviensis & Silva-Luz 290 (SPF) & $\mathrm{N}$ & $\mathrm{N}$ & $\mathrm{N}$ & $\mathrm{N}$ & $\mathrm{N}$ & $\mathrm{N}$ & $\mathrm{N}$ & $\mathrm{N}$ & $\mathrm{N}$ & $\mathrm{N}$ & - \\
\hline Schinus polygama & Silva-Luz 192 (SPF) & N & $\mathrm{N}$ & $\mathrm{N}$ & N & $\mathrm{N}$ & $\mathrm{N}$ & $\mathrm{N}$ & $\mathrm{N}$ & $\mathrm{N}$ & - & - \\
\hline Schinus polygama & Silva-Luz 198 (SPF) & $\mathrm{N}$ & $\mathrm{N}$ & $\mathrm{N}$ & $\mathrm{N}$ & $\mathrm{N}$ & $\mathrm{N}$ & - & $\mathrm{N}$ & $\mathrm{N}$ & $\mathrm{N}$ & - \\
\hline Schinus polygama & Niemeyer 128267 (SGO) & $\mathrm{N}$ & $\mathrm{N}$ & $\mathrm{N}$ & $\mathrm{N}$ & - & - & - & - & - & - & - \\
\hline
\end{tabular}


Table 1. (continued)

\begin{tabular}{|c|c|c|c|c|c|c|c|c|c|c|c|c|}
\hline Taxa & Voucher & ETS & ITS & rps16 & $t r n L-t r n F$ & 04620 & 20790 & 26580 & 44760 & 47760 & 48790 & 63160 \\
\hline Schinus polygama & Moreira 212386 (SPF) & $\mathrm{N}$ & $\mathrm{N}$ & $\mathrm{N}$ & $\mathrm{N}$ & - & - & $\mathrm{N}$ & - & $\mathrm{N}$ & $\mathrm{N}$ & - \\
\hline Schinus praecox & Silva-Luz 281 (SPF) & $\mathrm{N}$ & $\mathrm{N}$ & $\mathrm{N}$ & $\mathrm{N}$ & N & N & $\mathrm{N}$ & N & $\mathrm{N}$ & - & N \\
\hline Schinus roigii & Fortunato 4371 (US) & $\mathrm{N}$ & $\mathrm{N}$ & - & - & - & $\mathrm{N}$ & - & $\mathrm{N}$ & $\mathrm{N}$ & $\mathrm{N}$ & - \\
\hline Schinus spinosa & Hatschbach 19877 (NY) & $\mathrm{N}$ & $\mathrm{N}$ & $\mathrm{N}$ & $\mathrm{N}$ & $\mathrm{N}$ & $\mathrm{N}$ & - & - & $\mathrm{N}$ & - & - \\
\hline Schinus terebinthifolia var. acutifolia & Silva-Luz 264 (SPF) & $\mathrm{N}$ & $\mathrm{N}$ & $\mathrm{N}$ & $\mathrm{N}$ & N & $\mathrm{N}$ & $\mathrm{N}$ & N & $\mathrm{N}$ & - & $\mathrm{N}$ \\
\hline Schinus terebinthifolia var. pohliana & Silva-Luz 261 (SPF) & $\mathrm{N}$ & $\mathrm{N}$ & $\mathrm{N}$ & $\mathrm{N}$ & $\mathrm{N}$ & $\mathrm{N}$ & - & $\mathrm{N}$ & $\mathrm{N}$ & - & $\mathrm{N}$ \\
\hline Schinus rhoifolia & Silva-Luz 302 (SPF) & $\mathrm{N}$ & $\mathrm{N}$ & $\mathrm{N}$ & $\mathrm{N}$ & N & N & - & N & $\mathrm{N}$ & - & N \\
\hline Schinus rhoifolia & Sant'Ana 930 (NY) & $\mathrm{N}$ & $\mathrm{N}$ & $\mathrm{N}$ & $\mathrm{N}$ & $\mathrm{N}$ & $\mathrm{N}$ & - & $\mathrm{N}$ & $\mathrm{N}$ & - & - \\
\hline S. terebinthifolia var. terebinthifolia & Silva-Luz 205 (SPF) & $\mathrm{N}$ & $\mathrm{N}$ & $\mathrm{N}$ & $\mathrm{N}$ & $\mathrm{N}$ & - & - & N & $\mathrm{N}$ & $\mathrm{N}$ & $\mathrm{N}$ \\
\hline Schinus velutina & Silva-Luz 188 (SPF) & $\mathrm{N}$ & $\mathrm{N}$ & $\mathrm{N}$ & $\mathrm{N}$ & $\mathrm{N}$ & $\mathrm{N}$ & $\mathrm{N}$ & $\mathrm{N}$ & $\mathrm{N}$ & $\mathrm{N}$ & - \\
\hline Schinus velutina & Silva-Luz 197 (SPF) & $\mathrm{N}$ & $\mathrm{N}$ & $\mathrm{N}$ & $\mathrm{N}$ & $\mathrm{N}$ & $\mathrm{N}$ & $\mathrm{N}$ & $\mathrm{N}$ & $\mathrm{N}$ & $\mathrm{N}$ & $\mathrm{N}$ \\
\hline Schinus venturii & Serrano 4865 (MO) & $\mathrm{N}$ & $\mathrm{N}$ & $\mathrm{N}$ & $\mathrm{N}$ & - & N & - & - & - & - & - \\
\hline Schinus venturii & Serrano 5347 (MO) & $\mathrm{N}$ & $\mathrm{N}$ & $\mathrm{N}$ & $\mathrm{N}$ & - & N & - & N & - & $\mathrm{N}$ & - \\
\hline Schinus weinmanniifolia & Silva-Luz 315 (SPF) & $\mathrm{N}$ & $\mathrm{N}$ & $\mathrm{N}$ & $\mathrm{N}$ & N & N & $\mathrm{N}$ & N & - & - & - \\
\hline Schinus sp. nov. 3 & Silva-Luz 234 (SPF) & $\mathrm{N}$ & $\mathrm{N}$ & $\mathrm{N}$ & $\mathrm{N}$ & N & N & $\mathrm{N}$ & N & $\mathrm{N}$ & $\mathrm{N}$ & - \\
\hline Schinus sp. nov. 3 & Teran $1313(\mathrm{MO})$ & $\mathrm{N}$ & $\mathrm{N}$ & $\mathrm{N}$ & $\mathrm{N}$ & $\mathrm{N}$ & - & - & $\mathrm{N}$ & $\mathrm{N}$ & - & - \\
\hline Schinus sp. nov. 3 & Silva-Luz 251 (SPF) & $\mathrm{N}$ & $\mathrm{N}$ & $\mathrm{N}$ & $\mathrm{N}$ & N & N & $\mathrm{N}$ & $\mathrm{N}$ & $\mathrm{N}$ & $\mathrm{N}$ & - \\
\hline Schinus sp. nov. 3 & Silva-Luz 252 (SPF) & $\mathrm{N}$ & $\mathrm{N}$ & $\mathrm{N}$ & $\mathrm{N}$ & N & N & $\mathrm{N}$ & N & $\mathrm{N}$ & $\mathrm{N}$ & - \\
\hline Schinus sp. nov. 1 & Silva-Luz 215 (SPF) & $\mathrm{N}$ & $\mathrm{N}$ & $\mathrm{N}$ & $\mathrm{N}$ & $\mathrm{N}$ & - & $\mathrm{N}$ & $\mathrm{N}$ & $\mathrm{N}$ & - & $\mathrm{N}$ \\
\hline Schinus sp. nov. 1 & Silva-Luz 219 (SPF) & N & $\mathrm{N}$ & $\mathrm{N}$ & - & - & $\mathrm{N}$ & - & $\mathrm{N}$ & - & - & $\mathrm{N}$ \\
\hline Schinus sp. nov. 5 & Wood 11623 (LPB) & N & $\mathrm{N}$ & $\mathrm{N}$ & $\mathrm{N}$ & N & $\mathrm{N}$ & - & $\mathrm{N}$ & $\mathrm{N}$ & - & - \\
\hline Schinus sp. nov. 6 & Serrano 5050 (MO) & N & $\mathrm{N}$ & $\mathrm{N}$ & $\mathrm{N}$ & N & $\mathrm{N}$ & - & N & - & - & - \\
\hline Schinus sp. nov. 4 & Wood 12708 (LPB) & $\mathrm{N}$ & $\mathrm{N}$ & $\mathrm{N}$ & $\mathrm{N}$ & - & N & - & - & $\mathrm{N}$ & - & - \\
\hline Schinus sp. nov. 2 & Kausel 4045 (NY) & $\mathrm{N}$ & $\mathrm{N}$ & - & - & - & - & - & - & - & - & - \\
\hline
\end{tabular}


Table 2

Anacardiaceae outgroup studied, voucher information, and GenBank accession numbers. Sequences taken from GenBank are listed with the corresponding publication. New sequences were generated during this study.

\begin{tabular}{|c|c|c|c|c|c|c|}
\hline Taxa & Voucher & ETS & ITS & $r p s 16$ & $\operatorname{trnL}-\operatorname{trnF}$ & 44760 \\
\hline Toxicodendron radicans (L.) Kuntze & Pell 545 & $\begin{array}{l}\text { KP055334 } \\
\text { Weeks et al. } 2014\end{array}$ & - & $\begin{array}{l}\text { AY594642 } \\
\text { Pell (unpublished) }\end{array}$ & $\begin{array}{l}\text { AY594540 } \\
\text { Pell (unpublished) }\end{array}$ & - \\
\hline Toxicodendron radicans (L.) Kuntze & Wen 8570 & 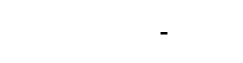 & $\begin{array}{l}\text { FJ945812 } \\
\text { Nie et al. (unpublished) }\end{array}$ & 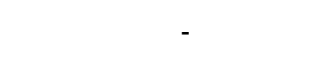 & 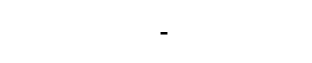 & - \\
\hline Myracrodruon urundeuva Allemão & Silva-Luz 300 (SPF) & New sequence & New sequence & New sequence & New sequence & New sequence \\
\hline $\begin{array}{l}\text { Myracrodruon balansae (Engl.) } \\
\text { Santin }\end{array}$ & Silva-Luz 332 & New sequence & New sequence & New sequence & New sequence & - \\
\hline $\begin{array}{l}\text { Amphipterygium adstrigens (Schltdl.) } \\
\text { Standl. }\end{array}$ & Pendry 845 & $\begin{array}{l}\text { KP055187 } \\
\text { Weeks et al. } 2014\end{array}$ & - & $\begin{array}{l}\text { AY594583 } \\
\text { Pell (unpublished) }\end{array}$ & New sequence & - \\
\hline Apterokarpos gardneri (Engl.) Rizinni & Pirani 2586 & $\begin{array}{l}\text { KP055192 } \\
\text { Weeks et al. } 2014\end{array}$ & - & $\begin{array}{l}\text { AY594585 } \\
\text { Pell (unpublished) }\end{array}$ & $\begin{array}{l}\text { AY594498 } \\
\text { Pell (unpublished) }\end{array}$ & - \\
\hline $\begin{array}{l}\text { Astronium fraxinifolium Schott } \\
\text { Astronium graveolens Jacq. } \\
\text { Astronium graveolens Jacq. } \\
\text { Astronium lecontei Ducke } \\
\text { Astronium sp. } \\
\text { Astronium nelson-rosae Santin }\end{array}$ & $\begin{array}{l}\text { Sevilha } 1832 \text { (NY) } \\
\text { Silva-Luz } 299 \text { (SPF) } \\
\text { Silva-Luz } 299 \text { (SPF) } \\
\text { INPA } 4421 \\
\text { Rando } 1088 \text { (SPF) } \\
\text { Silva-Luz } 301 \text { (SPF) }\end{array}$ & $\begin{array}{l}\text { New sequence } \\
\text { New sequence } \\
\text { New sequence } \\
\text { New sequence } \\
\text { New sequence } \\
\text { New sequence }\end{array}$ & $\begin{array}{l}\text { New sequence } \\
\text { New sequence } \\
\text { New sequence } \\
\text { New sequence } \\
\text { New sequence } \\
\text { New sequence }\end{array}$ & $\begin{array}{l}\text { New sequence } \\
\text { New sequence } \\
\text { New sequence } \\
\text { New sequence } \\
\text { New sequence } \\
\text { New sequence }\end{array}$ & $\begin{array}{l}\text { New sequence } \\
\text { New sequence } \\
\text { New sequence } \\
\text { New sequence } \\
\text { New sequence } \\
\text { New sequence }\end{array}$ & $\begin{array}{l}\text { New sequence } \\
\text { New sequence } \\
\text { New sequence } \\
\text { New sequence } \\
\text { New sequence } \\
\text { New sequence }\end{array}$ \\
\hline $\begin{array}{l}\text { Astronium concinnum Schott ex } \\
\text { Spreng. }\end{array}$ & Silva-Luz 305 (SPF) & New sequence & New sequence & New sequence & New sequence & New sequence \\
\hline Astronium glaziovii Mattick & Silva-Luz 303 (SPF) & New sequence & New sequence & New sequence & New sequence & New sequence \\
\hline Euroschinus vieillardii Engl. & Pell 1140 & $\begin{array}{l}\text { KP055230 } \\
\text { Weeks et al. } 2014\end{array}$ & - & $\begin{array}{l}\text { KP055391 } \\
\text { Weeks et al. } 2014\end{array}$ & $\begin{array}{l}\text { KP055511 } \\
\text { Weeks et al. } 2014\end{array}$ & - \\
\hline Euroschinus verrucosa Engl. & Guillaumin 12227 (NY) & $\begin{array}{l}\text { KP055229 } \\
\text { Weeks et al. } 2014\end{array}$ & - & $\begin{array}{l}\text { KP055390 Weeks et al. } \\
2014\end{array}$ & $\begin{array}{l}\text { KP055510 Weeks et al. } \\
2014\end{array}$ & - \\
\hline $\begin{array}{l}\text { Euroschinus papuana Merr. \& } \\
\text { L.M.Perry }\end{array}$ & Takeuchi $16409(\mathrm{~A})$ & $\begin{array}{l}\text { KP055228 } \\
\text { Weeks et al. } 2014\end{array}$ & - & $\begin{array}{l}\text { KP055389 Weeks et al. } \\
2014\end{array}$ & $\begin{array}{l}\text { KP055509 Weeks et al. } \\
2014\end{array}$ & - \\
\hline Euroschinus jaffrei M. Hoff & McPherson 18174 (MO) & $\begin{array}{l}\text { KP055227 } \\
\text { Weeks et al. } 2014\end{array}$ & - & $\begin{array}{l}\text { KP055388 Weeks et al. } \\
2014\end{array}$ & $\begin{array}{l}\text { KP055508 Weeks et al. } \\
2014\end{array}$ & - \\
\hline Euroschinus falcata Hook. f. & Herscovitch s.n. (NY) & $\begin{array}{l}\text { KP055226 } \\
\text { Weeks et al. } 2014\end{array}$ & - & $\begin{array}{l}\text { KP055387 Weeks et al. } \\
2014\end{array}$ & $\begin{array}{l}\text { KP055507 Weeks et al. } \\
2014\end{array}$ & - \\
\hline Euroschinus elegans Engl. & Munzinger $6642(\mathrm{BKL})$ & $\begin{array}{l}\text { KP055225 } \\
\text { Weeks et al. } 2014\end{array}$ & - & $\begin{array}{l}\text { KP055386 Weeks et al. } \\
2014\end{array}$ & $\begin{array}{l}\text { KP055506 Weeks et al. } \\
2014\end{array}$ & - \\
\hline Euroschinus aoupiniensis Hoff & Pell 1134 (BKL) & $\begin{array}{l}\text { KP055224 } \\
\text { Weeks et al. } 2014\end{array}$ & - & $\begin{array}{l}\text { KP055385 Weeks et al. } \\
2014\end{array}$ & $\begin{array}{l}\text { KP055505 Weeks et al. } \\
2014\end{array}$ & - \\
\hline $\begin{array}{l}\text { Schinopsis balansae Engl. } \\
\text { Schinopsis peruviana Engl. }\end{array}$ & $\begin{array}{l}\text { Silva-Luz } 317 \text { (SPF) } \\
\text { Villacorta } 4151 \text { (USM) }\end{array}$ & $\begin{array}{l}\text { New sequence } \\
\text { New sequence }\end{array}$ & $\begin{array}{l}\text { New sequence } \\
\text { New sequence }\end{array}$ & $\begin{array}{c}\text { New sequence } \\
-\end{array}$ & New sequence & $\begin{array}{l}- \\
-\end{array}$ \\
\hline Schinopsis peruviana Engl. & Genty 27850 (NY) & - & - & New sequence & New sequence & - \\
\hline Schinopsis marginata Engl. & Silva-Luz 285 (SPF) & New sequence & New sequence & New sequence & New sequence & - \\
\hline Schinopsis cornuta Loes. ex Herzog & Silva-Luz 318 (SPF) & New sequence & New sequence & New sequence & New sequence & - \\
\hline Schinopsis lorentzii (Griseb.) Engl. & Silva-Luz 238 (SPF) & New sequence & New sequence & New sequence & New sequence & - \\
\hline Schinopsis brasiliensis Engl. & Silva-Luz 306 (SPF) & New sequence & New sequence & New sequence & New sequence & - \\
\hline Lithrea brasiliensis Marchand & Silva-Luz 218 (SPF) & New sequence & New sequence & New sequence & New sequence & - \\
\hline
\end{tabular}


Table 2 (continued)

Taxa

Lithrea brasiliensis Marchand

Lithrea molleoides (Vell.) Engl.

Lithrea caustica Hook. \& Arn.

Mauria heterophylla Kunth

Mauria simplicifolia Kunth

Mauria subserrata Loes.

Mauria thaumatophylla

Mauria suaveolens Loes.
Orthopterygium huaucui (A. Gray)

Hemsl.

Ochoterenaea colombiana F.A.

Barkley

Cardenasiodendron brachypterum

(Loes.) F.A. Barkley

Cardenasiodendron brachypterum

(Loes.) F.A. Barkley

Thyrsodium spruceanum Benth.

Loxopterygium grisebachii Hieron

Loxopterygium grisebachii Hieron.

Loxopterygium huasango Spruce ex

Engl.

Loxopterygium huasango Spruce ex

Engl.

Loxopterygium huasango Spruce ex

Engl.

Mello-Silva 3739 (SP)

ETS

New sequence

ITS

New sequence

New sequence

New sequence

New sequence

New sequence

Silva-Luz 345 (SPF)

New sequence

New sequence

Silva-Luz 346 (SPF)

New sequence

New sequence

Silva-Luz 341 (SPF) New sequence

New sequence

New sequence

New sequence

Silva-Luz 343 (SPF)

New sequence

New sequence

New sequence

Silva-Luz 340 (SPF)

KP055262

Sánchez 2598 (F)

Weeks et al. 2014

Silva-Luz 236 (SPF)

New sequence

Pendry 691 (E)

KP055208

Silva-Luz 90 (SPF)

Silva-Luz 236 (SPF)

Pendry 678 (E)

Weeks et al. 2014

New sequence

New sequence

KP055247 AY531207

-

New sequence

New sequence

Silva-Luz 344 (SPF)

eeks et al. 2014

Pennington et al. 2004

rps16

New sequence

New sequence

New sequence

New sequence

New sequence

New sequence

New sequence

New sequence

KP055413

Weeks et al. 2014

New sequence

KP055375

Weeks et al.2014

New sequence

New sequence

KP055402

New sequence

Pennington $813(E)$

-

AY531205

Pennington et al. 2004

AY531206

Pennington $816(\mathrm{E})$

Loxopterygium sagotii Hook. $f$.

Polak 309 (E)

KP055248

Pennington et al. 2004

Weeks et al 2014

\begin{tabular}{lc} 
trnL-trnF & 44760 \\
\hline- & - \\
New sequence & - \\
New sequence & New sequence \\
New sequence & - \\
New sequence & - \\
New sequence & - \\
New sequence & - \\
New sequence & - \\
New sequence & - \\
AY594561 & - \\
Weeks et al.2014 & - \\
New sequence & - \\
AY594503 & - \\
Pell (unpublished) & - \\
New sequence & - \\
New sequence & - \\
KP055520 & - \\
Weeks et al.2014 & - \\
New sequence & - \\
- & - \\
KP055521 & - \\
Weeks et al. 2014 & -
\end{tabular}

Table 2 (continued)

\begin{tabular}{llllllll} 
Table 2 (continued) & & & & \\
\hline Taxa & Voucher & 4620 & 20790 & 26580 & 47760 & 48790 & 63160 \\
\hline $\begin{array}{l}\text { Lithrea } \\
\text { brasiliensis }\end{array}$ & Silva-Luz & - & - & - & New & New & - \\
$\begin{array}{l}\text { Marchand } \\
\text { Lithrea molleoides }\end{array}$ & Silva-Luz & New & New & New & New & New & - \\
(Vell.) Engl. & 298 (SPF) & sequence & sequence & Sequence & sequence & sequence & \\
\hline
\end{tabular}


Table 3

Characteristics of the DNA regions used for the phylogenetic analyses of Schinus. See text for more details. *Locus linked in BEAST.

\begin{tabular}{|c|c|c|c|c|c|c|}
\hline & ETS & ITS & rps16 & trnL-trnF & 4620 & 20790 \\
\hline Number of Sequence & 123 & 103 & 118 & 116 & 62 & 69 \\
\hline Alignment length (pb) & 336 & 675 & 896 & 891 & 422 & 247 \\
\hline $\begin{array}{l}\text { Number of constant } \\
\text { characters }\end{array}$ & 136 & 384 & 801 & 805 & 403 & 229 \\
\hline $\begin{array}{l}\text { Number of variable } \\
\text { characters }\end{array}$ & 200 & 291 & 95 & 86 & 19 & 18 \\
\hline $\begin{array}{l}\text { Best-fit model } \\
\text { (AIC criterion) } \\
\text { jModeltest } \\
\text { Best-fit model } \\
\text { (AIC criterion) }\end{array}$ & $\mathrm{GTR}+\mathrm{G}$ & $\mathrm{GTR}+\mathrm{G}+\mathrm{I}$ & $\mathrm{GTR}+\mathrm{G}+\mathrm{I}$ & $\mathrm{GTR}+\mathrm{G}+\mathrm{l}$ & $\mathrm{HKY}+\mathrm{I}$ & TN93+I \\
\hline & $\begin{array}{l}\text { 5'TTCGGT } \\
\text { ATCCTGT } \\
\text { GTTGCTT } \\
\text { AC 3' }\end{array}$ & $\begin{array}{l}\text { 5'CCTTAT } \\
\text { CATTTAG } \\
\text { AGGAAG } \\
\text { GAG 3' }\end{array}$ & $\begin{array}{l}\text { 5'GTGGT } \\
\text { AGAAAGC } \\
\text { AACGTGC } \\
\text { GACTT 3' }\end{array}$ & $\begin{array}{l}\text { 5'CATTAC } \\
\text { AAATGCG } \\
\text { ATGCTCT } \\
3^{\prime}\end{array}$ & $\begin{array}{l}\text { 5'TCCACC } \\
\text { ATATTTT } \\
\text { GAGTGA } \\
\text { GAGGAA } \\
\text { 3' }\end{array}$ & $\begin{array}{l}\text { 5'CCAATT } \\
\text { GTCAATG } \\
\text { GTCTCTG } \\
\text { AAGATG } \\
\text { 3' }\end{array}$ \\
\hline Primer & $\begin{array}{l}\text { 5'GAGAC } \\
\text { AAGCATA } \\
\text { TGACTAC } \\
\text { TGGCAG } \\
\text { GATCAAC } \\
\text { CAG 3' }\end{array}$ & $\begin{array}{l}\text { 5'TATGCT } \\
\text { TAAAYTC } \\
\text { AGCGGG } \\
\text { T 3' }\end{array}$ & $\begin{array}{l}\text { 5'TCGGG } \\
\text { ATCGAAC } \\
\text { ATCAATT } \\
\text { CGAAC 3' }\end{array}$ & $\begin{array}{l}\text { 5'ATTTGA } \\
\text { ACTGGTG } \\
\text { ACACGA } \\
\text { G 3' }\end{array}$ & $\begin{array}{l}\text { 5'AATGG } \\
\text { GAGTGG } \\
\text { GAATGAG } \\
\text { AATGTG } \\
\text { 3' }\end{array}$ & $\begin{array}{l}\text { 5'CCATG } \\
\text { GTGCAAA } \\
\text { TTTAACT } \\
\text { GTTCC 3' }\end{array}$ \\
\hline
\end{tabular}

Table 3 (continued)

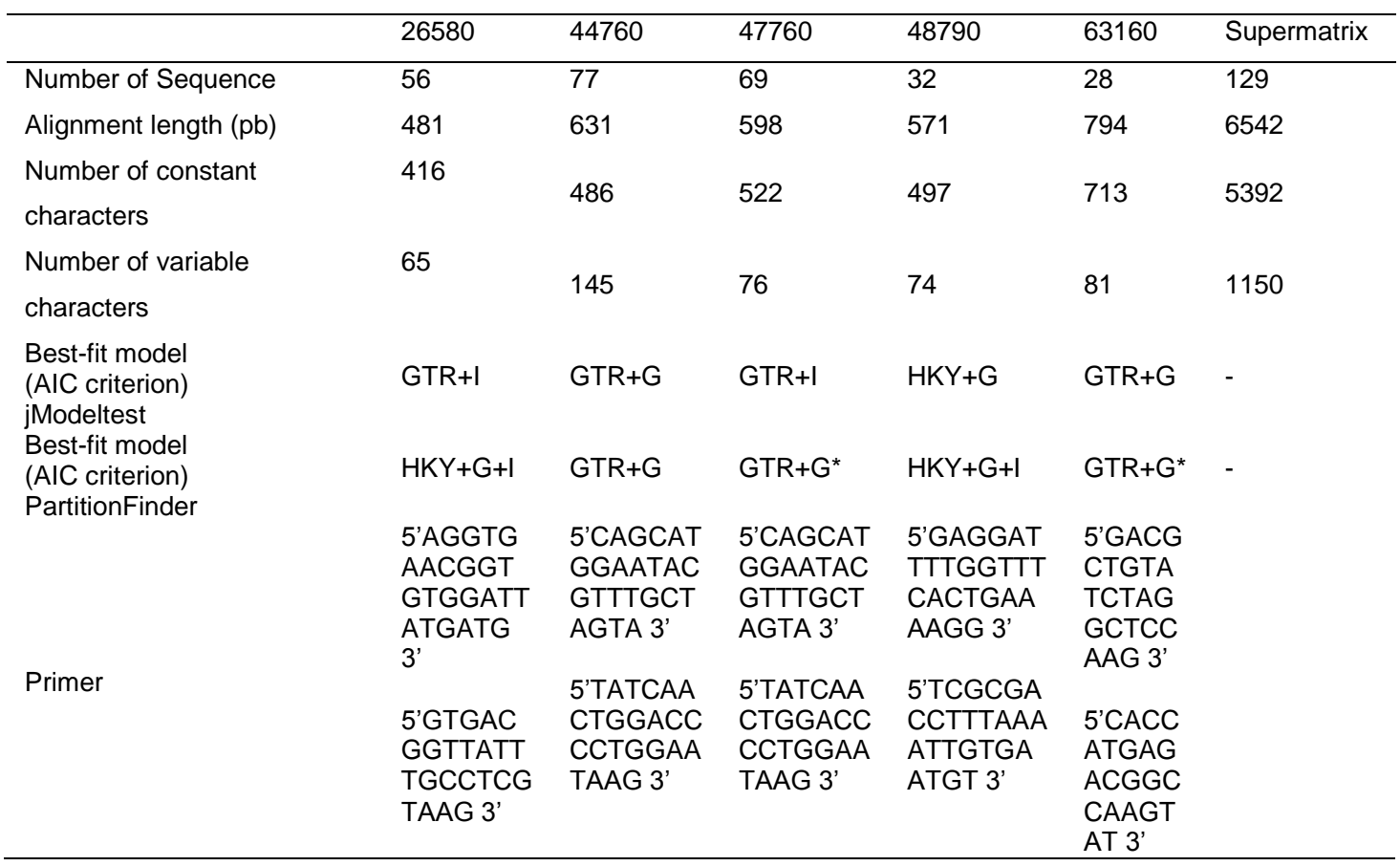

data, especially involving the leaf anatomical characters, we reduced the outgroup to the two closest genera (i.e., Lithrea and Mauria). However, for the reconstruction of leaf division characters and secondary vein framework, we used the entire outgroup to avoid the equivocal reconstruction among Lithrea and Mauria, which could hamper the interpretation of evolutionary reconstruction of such characters. The matrix with all morphological characters and character states is provided in table 5 . 


\subsection{Taxonomic classification and biogeographical notes}

In the novel infrageneric classification proposed herein, we chose to use only the sectional rank. All sections reflect strongly supported monophyletic groups based on the phylogenetic analysis. Our classification follows the sequencing convention (Nelson, 1972), because the aplication of the subordination convention (Nelson, 1972) would demand a much higher number of taxonomic ranks, rendering a more complex classification system that would make taxonomic determinations more difficult. Moreover, even though our sampling is almost complete, future analyses including more terminals of Schinus could result in alternative topologies, which would require more extensive modifications to a classification constructed by subordination.Nomenclatural controversial concerning the orthographic variants of the specific epithets in Schinus was recently addressed. In particular, we agree with Zona (2015), who presented consistent arguments based on nomenclatural tradition (Art. 62.1, McNeill et al., 2011) demonstrating that Schinus should be treated as feminine in the construction of combinatons. The clades recognized as sections in Schinus are characterized either by putative synapomorphic morphological features identified in the present analyses or using a combination of structural characters and geographic distribution. The vegetation types and biogeographic regions and provinces cited in the comments following each sectional description follow the general classification systems of Cabrera \& Willink (1973), Lomolino et al. (2006), and Olson et al. (2001). Table 4

Characters states used for the character reconstruction on the Bayesian topology, for Schinus and other genera in Anacardiaceae. For the parenchyma of the petiole (character 12), we recognized as homogeneous type, the standard parenchyma with few chloroplasts and small intercellular spaces, and as spongy type, the parenchyma with many chloroplasts and large intercellular spaces. Since the homogeneous parenchyma of the petiole is essentially present, it was not coded when other types of parenchyma were observed.

\begin{tabular}{ll}
\hline Characters & Character states \\
\hline $\mathbf{1}$ Thorny branches & (0) Absent / (1) Present \\
$\mathbf{3}$ Leaflet arrangement & $(0)$ Compound (pinnate) / (1) Simple /(2) Dissected \\
$\mathbf{4}$ Rachis & $(0)$ Imparipinnate / (1) Paripinnate / (2) Not applicable \\
$\mathbf{5}$ Secondary vein framework & $(0)$ Winged / (1) Terete / (2) Not applicable \\
$\mathbf{6}$ Inflorescence type & $(0)$ Cladodromous / (1) Craspedodromous/ (2) Brochidodromous \\
$\mathbf{7}$ Floral merosity & $(0)$ Pseudoraceme / (1) Thyrsoid / (2) Panicle \\
$\mathbf{8}$ Petal to stamen size ratio & $(0) 5$ / (1) 4 \\
$\mathbf{9}$ Fruit shape & $(0)$ Petals longer than stamens/ (1) Petals shorter than stamens / (2) \\
$\mathbf{1 0}$ Fruit lateral shape & Petals as long as stamens \\
$\mathbf{1 1}$ Fruit collor & (0) Globose / (1) Ovoid / (2) Obovoid \\
$\mathbf{1 2}$ Parenchyma of the petiole & (0) Laterally compressed laterally / (1) Rounded \\
$\mathbf{1 3}$ Vascular bundles of the petiole & (0) Purple / (1) Red / (2) Pink / (3) Green / (4) Orange / (6) Dark red \\
$\mathbf{1 4}$ Mesophyll arrangement & $(0)$ Homogeneous / (1) Spongy on both sides / (2) Palisade on adaxial \\
$\mathbf{1 5}$ Vascular bundle of the midrib & side and spongy on abaxial side \\
\hline
\end{tabular}




\section{Results}

\subsection{Phylogenetic analyses}

Since no incongruence (BPP > 0.95) among the different partitions was detected through preliminary individual Bayesian analyses (Figs. 1-8, Appendix 1) and most of the clades defined by these trees remained consistent, the combined dataset of all 11 partitions was analyzed simultaneously. Analyses of the combined dataset resulted in similar tree topologies regardless of methodology (MP, Fig. 10, Appendix 1; ML, Fig. 9, Appendix 1; and BI, Figure 2), but the Bayesian inference recovered a phylogenetic tree that is both better resolved and has higher support for most of the main clades. We have therefore chosen to present the results of the combined dataset using the $\mathrm{BI}$ topology for subsequent discussion, although clade support $(\geq 50 \%)$ from all three analyses (bootstrap percentage from MP and ML analyses and PP values from the $\mathrm{BI}$ analysis) are indicated along the branches in the $\mathrm{BI}$ tree in Figure 2. Dataset and tree statistics are provided in table 3.

The level of phylogenetic resolution differed between the plastid and nuclear genomes, with nuclear regions (Figs. 1-6, see Appendix 1) generally providing greater resolution towards the terminals, and the plastid regions providing resolution along the deeper "backbone" of the tree (Figs. 7-8, see Appendix 1). Schinus was recovered as monophyletic (BS 100, BS 100, PP 1), sister to a clade comprising three genera, Lithrea, Mauria and Euroschinus (Fig. 1). The main goal of this study is focused on the systematics of Schinus, and therefore we do not focus on other genera of Anacardiaceae. Within Schinus (Fig. 2), taxa having compound leaves are the earliest diverging lineages, forming a grade of three strongly supported clades (BS 99-100, BS 100, BI 1). Clade 1 diverged first, and comprises $S$. terebinthifolia, $S$. weinmanniifolia and S. rhoifolia (Schinus sect. Terebinthifolia). Clade 2 contains $S$. areira and S. molle (Schinus sect. Schinus), and clade 3 has a single species, $S$. lentiscifolia (Schinus sect. Lentiscifolia) which is sister to all remaining species. The relationships are clearly resolved and well supported among all the compound-leaved grades with exception of $S$. sect. Schinus, whose relationship to the remaining clades was not strongly supported in Bayesian analysis (PP 0.93, Fig. 2). This node also received less than $50 \%$ of support in $\mathrm{ML}$ analysis (Fig. 9, Appendix 1) and was placed in a basal polytomy with S. sect. Terebinthifolia in the MP analysis (Fig. 10, Appendix 1). In the individual Bayesian analysis of ETS (Fig. 5A, Appendix 1), S. sect. Schinus was placed as sister to $S$. sect. Terebinthifolia but with weak support (PP 0.56). The larger Schinus clade (clades 4-8; BS 99, BS 100, PP 1) consists primarily of simpleleaved species, with exception of Schinus pearcei (clade 5) and has five main 
lineages. Clades 4 and 5 are sister to each other, but both clades were recovered only in the Bayesian analysis. In MP and ML analyses, taxa from these clades are poorly resolved (Figs. 9-10, Appendix 1). Clade 5, Schinus sect. Pilifera, is strongly supported (PP 0.99), but clade 4, Schinus sect. Atlantica, is not (PP 0.79). These two clades are sister to clades 6, 7 and 8, which are recovered in most analyses. Clade 6, Schinus sect. Montana, is strongly supported in the Bayesian analysis (BS 53, BS 60 , PP 1), where it is sister to clades $7+8$. Clade 7 , Schinus sect. Duvaua, is a well supported clade (BS 82, BS 95, PP 1) that is sister to clade 8 (Schinus sect. Myrtifolia), which is also well supported in the Bayesian and likelihood analyses (BS 62, BS 98, PP 1). The MP analysis recovered clades 1+2, 3, 4 and 5, comprising the simple-leaved species, but failed to resolve relationships among these clades (Fig. 10, Appendix 1). Overall, relationships among the main clades in Schinus are reasonably well supported ( $P P \geq 0.95$ ), but closely related species are poorly supported, especially among species from clades 5 and 8.

\subsection{Morphological inference}

We present state reconstructions of 10 selected morphological characters (Figs. 3-4). The reconstruction of thorny branches (Fig. 3A) was homoplastic, occurring five times independently within the simple-leaved clade, but when considered alongside other characters, such as petal to stamen size ratio (Fig. 3C) and floral merosity (Fig. 3B), thorny branches were useful in circumscribing clades 4 (Schinus sect. Atlantica) and 5 (Schinus sect. Pilifera). Another relevant character for infrageneric classification in Schinus is leaf division. Simple leaves characterize the largest lineage in Schinus and this feature evolved from compound-leaved ancestors in the genus. Only one reversal to compound leaves was identified in Schinus, in clade 5 (i.e. Schinus pearcei), but this character state has probably evolved at least four times independently among other genera closely related to Schinus (Fig. 4A). Within the compound-leaved grade of Schinus, a decrease in leaflet arrangement (table 4, character number 3) was observed in which clades 1 (Schinus sect. Terebinthifolia) and 2 (Schinus sect. Schinus) have imparipinnate leaves, whereas $S$. lentiscifolia (clade 3) has paripinnate leaves, lacking the terminal leaflet. The most common pattern of secondary veins in Schinus is craspedodromous and cladodromous (Fig. 4B). These character states are homoplastic and the reconstructions showed that they evolved multiple times within the genus, and more broadly in genera related to Schinus. This character might be useful in characterizing some clades, particularly clades 6 (Schinus sect. Montana), 7 (Schinus sect. Duvaua) and 8 (Schinus sect. Myrtifolia), when considered together with other morphological 
features. Another homoplastic characters relevant for diagnosing simple-leaved clades is the ratio of petal to stamen sizes (Fig. 3C). The inflorescences in the genus are usually classified mainly as panicles or pseudoracemes (table 4, character 6). Our analysis suggests that pseudoracemes probably evolved from panicles, which are plesiomorphic for Schinus, but with a reversal to panicles or thyrsoids occurring several times within the simple-leaved lineage. The evolutionary mapping of floral merosity and fruit lateral shape (fig. 3B, D) showed that the presence of tetramerous flowers and laterally compressed fruits are informative for characterizing species from Schinus sect. Myrtifolia (clade 8). Lineages of Schinus with tetramerous flowers probably evolved from ancestors bearing pentamerous flowers. Species from $S$. sect. Duvaua bear either mixed tetramerous and pentamerous flowers, whereas species from S. sect. Myrtifolia have only tetramerous flowers. Laterally compressed fruits are an unusual trait in Schinus, occurring only in clade 8, but seems to have evolved a few times independently among other genera closely related to Schinus. Our morphological reconstructions highlight both flower merosity and fruit shape as potential synapomorphies for Schinus sect. Myrtifolia.

Leaf anatomical characters, in particular features related to the vascular bundles of the petiole and midrib (Fig. 5 A-B, D-E), were also informative for identifying some clades. The evolutionary mapping of the petiolar vascular bundles suggests that crescent-shaped bundles evolved from the crescent-shaped and dorsal bundle state. While the reconstruction reveals two reversals, this character state seems to be consistent in characterizing clades 4 and 5 (Fig. 3F). Even though the evolutionary reconstruction of the vascular bundles of the midrib revealed that crescent-shaped bundles are homoplastic, it was also informative for characterizing clades 4 and 5 , as well as clade 8 (Fig. $3 \mathrm{H}$ ). In the evolutionary mapping of the mesophyll arrangement, the dorsiventral character state (Fig. 5G) probably evolved from the isobilateral one (Fig. 5F), and seems to be a potential synapomorphy shared by clades 6,7 and 8 (Fig. 3G). However this character state seems to have evolved independently among the genera closely related to Schinus (e.g. Mauria). Our analysis indicates three different types of parenchyma in the petioles of Schinus (Fig. $5 \mathrm{~A}-\mathrm{C}$ ). In the compound-leaved grade, clade 1 has spongy parenchyma (Fig. $5 \mathrm{C}$ ), clades 2 and 3 have spongy parenchyma on the abaxial surface and palisade parenchyma on the adaxial surface (fig. 5A), and the simple-leaved clade has homogeneous parenchyma (Fig. 5B). This latter type of parenchyma is homoplastic in the family, occurring also in Lithrea brasiliensis and Mauria subserrata (Fig. 3E). 


\section{Discussion}

\subsection{Phylogenetic relationships and taxonomic implications}

In this study, we tested for the first time the monophyly of Schinus and its infrageneric categories using a near-comprehensive sampling. Previous phylogenetic studies in Anacardiaceae used one sample of Schinus (Al-Saghir, 2010; Miller et al., 2001; Nie et al., 2009; Pell et al., 2008; Yi et al., 2004, 2007, 2008; Xie et al., 2014), or more recently, five specimens of Schinus (Weeks et al., 2014), providing a preliminary confirmation of the monophyly of the genus. Our results confirmed the monophyly of Schinus and its relationship as sister to a clade comprising Lithrea, Mauria and Euroschinus, as demonstrated in the study of Weeks et al. (2014), agreeing with Barkleys (1957) earlier observation that Lithrea and Mauria are morphologically similar to Schinus.

Table 5

Matrix used for the ancestral state reconstruction of morphological characters for Schinus and closest related genera in Anacardiaceae and voucher information.

\begin{tabular}{|c|c|c|c|}
\hline Taxa & Characters & Voucher & Anatomy vouchers \\
\hline Lithrea brasiliensis & 12212010050011000 & Silva-Luz 218 & $\mathrm{X}$ \\
\hline Lithrea molleoides & $0(01) 0012010050011001$ & Silva-Luz 298 & \\
\hline Mauria simplicifolia & 12202011010011000 & Silva-Luz 346 & \\
\hline Mauria subserrata & $0(01) 01020110(14) 0011101$ & Silva-Luz 341 & $\mathrm{x}$ \\
\hline Schinus areira & 12020110031011 & Silva-Luz 245 & $\mathrm{x}$ \\
\hline Schinus bumelioides & 11220(01)01010??????? & Silva-Luz 277 & \\
\hline Schinus sp. nov. 3 & 12200100011101100 & Silva-Luz 251 & $\mathrm{X}$ \\
\hline Schinus engleri & $1122000101(123) 0100010$ & Silva-Luz 161 & $\mathrm{x}$ \\
\hline Schinus engleri var. uruguayensis & $1122000101(01) 1100010$ & Silva-Luz 217 & $\mathrm{x}$ \\
\hline Schinus fasciculata & 11220(01)01010??????? & Degen 3254 & \\
\hline Schinus ferox & $1122(01) 00101(01) 1101010$ & Silva-Luz 333 & $\mathrm{x}$ \\
\hline Schinus gracilipes & 01220(012)10101??????? & Pell 1008 & \\
\hline Schinus johnstonii & 1122(02)001010??????? & Silva-Luz 268 & \\
\hline Schinus sp. nov. 2 & 01221002?????????? & Kausel 4045 & \\
\hline Schinus latifolia & $01221(01)(01) 10101101101$ & Silva-Luz 187 & $\mathrm{x}$ \\
\hline Schinus lentiscifolia & $0010120001(12) 0021011$ & Silva-Luz 220 & $\mathrm{x}$ \\
\hline Schinus longifolia & 1122(02)(012)01010??????? & Silva-Luz 214 & \\
\hline Schinus marchandii & 11221002010??????? & Silva-Luz 272 & \\
\hline Schinus sp. nov. 1 & $1122(01)(01) 010101300010$ & Silva-Luz 215 & $\mathrm{x}$ \\
\hline Schinus meyeri & 01220(01)10102??????? & Gallegos 305 & \\
\hline Schinus microphylla & 112200100111100000 & Silva-Luz 255 & $\mathrm{X}$ \\
\hline Schinus molle & 00001200011??????? & Silva-Luz 374 & \\
\hline Schinus montana & 12210020101101100 & Silva-Luz 193 & $\mathrm{X}$ \\
\hline Schinus myrtifolia & $0122001020(12) 110(01) 100$ & Silva-Luz 292 & $\mathrm{x}$ \\
\hline Schinus sp. nov. 5 & 01220(01)10001??????? & Wood 11623 & \\
\hline Schinus odonellii & 112210020101101000 & Silva-Luz 274 & $\mathrm{X}$ \\
\hline Schinus patagonica & 12210020101101100 & Silva-Luz 201 & $\mathrm{x}$ \\
\hline Schinus pearcei & $0(01) 0012020111101011$ & Silva-Luz 256 & $\mathrm{X}$ \\
\hline Schinus pilifera & 112201010101100000 & Silva-Luz 230 & $\mathrm{x}$ \\
\hline Schinus polygama var. polygama & $11221(01)(01) 10101101101$ & Silva-Luz 192 & $\mathrm{x}$ \\
\hline Schinus polygama var. parviflora & 11221(01)(01)1010??????? & Muñoz 212386 & \\
\hline Schinus praecox & 112200010101100000 & Silva-Luz 281 & $\mathrm{x}$ \\
\hline Schinus roigii & 11221002013??????? & Fortunato 4371 & \\
\hline Schinus sinuata & 1122(02)(01)01013??????? & Silva-Luz 330 & \\
\hline & & Hatschbach & $\mathrm{x}$ \\
\hline Schinus spinosa & $1122(01) 00101(13) 1100000$ & 19877 & \\
\hline Schinus sp. nov. 6 & 01220010(01)0(12)??????? & Serrano 5050 & \\
\hline Schinus terebinthifolia var. & & Silva-Luz 205 & $\mathrm{x}$ \\
\hline terebinthifolia & 2020110011001???????? & & \\
\hline Schinus rhoifolia & 00010202011??????? & Silva-Luz 302 & \\
\hline Schinus velutina & $01221(01)(01) 10101101101$ & Silva-Luz 188 & $\mathrm{x}$ \\
\hline Schinus venturii & 0122001010(12)??????? & Serrano 4865 & \\
\hline Schinus sp. nov. 4 & 01220010(0 1)0(12)??????? & Wood 12708 & \\
\hline Schinus weinmanniifolia & $000002020(01) 11241011$ & Silva-Luz 311 & $\mathrm{x}$ \\
\hline
\end{tabular}




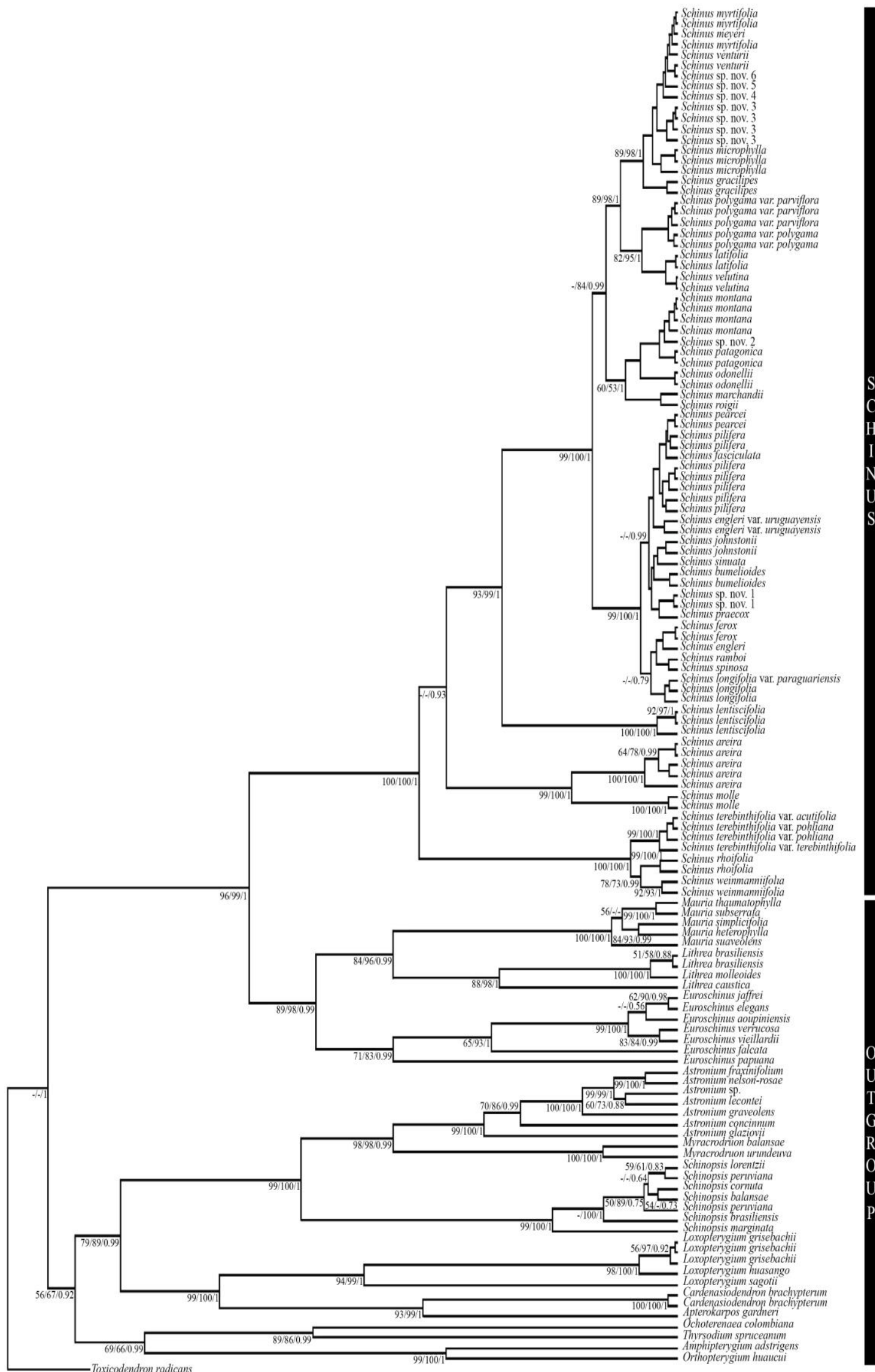

Fig. 1. A cladogram of the Bayesian half-compatible consensus of Schinus phylogeny and closely related genera from Anacardiaceae, based on the combined pool of post-burn trees from analyses of the combined plastid and nuclear DNA regions. Branch lengths are calculated from means of the posterior probability density. Parsimony bootstrap, maximum likelihood bootstrap and posterior probability values, respectively, are associated with branches. A dash indicates that support was less than $50 \%$. Nodes values for Schinus are presented only for the main clades. Values for all supported nodes in Schinus are presented in figure 2. 
A

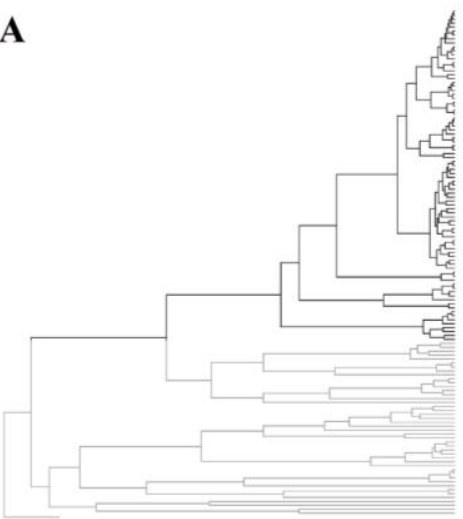

8 Schinus sect. Myrtifolia

7 Schinus sect. Duvaua

Schinus sect. Montana

5 Schinus sect. Pilifera

4 Schinus sect. Atlantica

3 Schinus sect. Lentiscifolia

1 Schinus sect. Terebinthifolia
B ${ }^{586000.81}>$ Schimus myrtifolia - Schinus meyeri Lchinus myrtifolia - Schimus venturii 6266\%. $>$ - $\begin{aligned} & \text { Schimus venturii } \\ & \text { Schinus sp. nov. } 6\end{aligned}$ +10.99 Schimus sp. nov. 5 511520.98 Schinus sp. nov. 3 7873\%. $\quad\left[\begin{array}{l}\text { Schimus sp. nov. } 3 \\ \text { Schinus sp. nov } 3\end{array}\right.$ Schimus sp. nov. 3 Schimus sp. nov. 3 L Schinus microphylla - Schinus microplylla - Schinus gracilipes - Schinus gracilipes

[- Schimus polygama var. parviflora Schimis polygama var. parviflora Cchimis polygama var. parviftora Schinus polygama var. polygama Schinus polygama var. polygama 820.97-r Schinus latifolia Schinus latifolia Schimus velutina Schimus velutina Schinus montana ${ }_{98}^{-7750.92-[1-2 c h i m u s ~ m o n t a n a}$ LChinus montana 63/-0.99 2 Schimus sp. nov. 2 90/98:- - Schimus patagonica 99\% $[$ Schinus odonellii Schimus odonellii

Schinus marchandit Schimus roigii

99\%
Schimus pearcei
Schinus pearcei

-164-_ - Schinus pilifera Schinus pilifera

50164/0.99 — Schimus fasciculata 85:190\%. Schinus pilifera 60/57/0.83 $\longrightarrow$ Schimus pilifera 52/51095 - Schimus pilifera 2/510.95 $\square-$ Schinus pilifera

68/87\%. Schimus engleri var. uruguavensis Schimus engleri var. uruguavensis

$+10.99$ $1+10.77-\left[\begin{array}{l}\text { Schinus jolmstonii } \\ \text { Schimus johnstonii }\end{array}\right.$ Schinus simuata

- Schinus bumelioides

Schimus bumelioides

99/99.- Schinus sp. nov. 1

Schimus sp. nov.

Schinus praecor

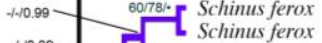

Schimus engleri var. engleri

H-10.98 Schimus ramboi

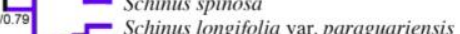

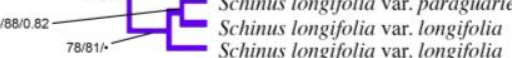
Schinus lentiscifolia Schinus lentiscifolia

S47788.0.99 Schinus areira

- 5 Schimis areira

Schinus areira

Schimus areira Schimus areira - Schinus molle 7016610.98 드 Schinus molle

Schimus molle

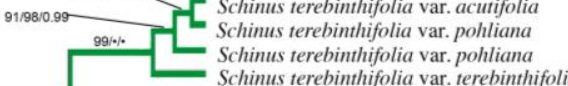

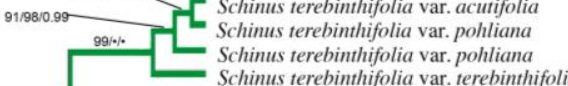

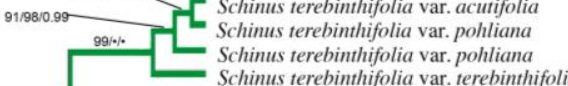
Schinus rhoifolia

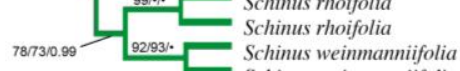

Outgroup

Fig. 2. A - Bayesian half-compatible consensus of Schinus phylogeny and closely related genera from Anacardiaceae. B - Cladogram of the Bayesian half-compatible consensus tree of Schinus based on the combined pool of post-burn trees from analyses of the combined plastid and nuclear DNA regions. Branch lengths are calculated from means of the posterior probability density. Parsimony bootstrap, maximum likelihood bootstrap and posterior probability values, respectively, are associated with branches; a filled circle indicates a bootstrap value of $100 \%$ or a posterior probability of one, a dash indicates that support was less than $50 \%$; a star represents the simple-leaved lineage of Schinus. Clades described in the text correspond to the numbers labeled on the right. 
These three genera can be characterized by a combination of characters based mainly on anatomical features of the flowers and fruits. All three have simple or compound leaves, but only Schinus has some species that bear thorny branches, a homoplastic character among the simple-leaved lineage. Flowering morphology is very similar between these genera, all having unisexual, dichlamydeous, pentamerous (rarely tetramerous) flowers. Even though, obdiplostemony seems to be the common pattern in Sapindalean families as well as among taxa in Anacardiaceae (Bachelier and Endress, 2009; Eckert, 1966; Gut, 1966; Harms, 1940), Schinus, Lithrea and Mauria have diplostemonous androecium (Lithrea and Mauria in Pell et al., 2011; Schinus in Bachelier and Endress, 2009 and Pell et al., 2011). The ontogenetic study of the gynoecium of $S$. molle showed that the position of the fertile carpel appears to be variable (i.e. either antesepalous, antepetalous or in between) and may lead to a mismatch of the symmetry plane of the gynoecium with that of perianth plus androecium (Bachelier and Endress, 2009). Further ontogenetic investigations using a broader sampling from Schinus might be useful in demonstrating the main pattern of androecium in other lineages of the genus. The drupe-like fruits are also similar among these genera and can vary mainly in lateral shape and color. Lithrea has grayish-green fruits, whereas the fruits of Schinus and Mauria display a wider range of colors. Anatomical studies of the pericarp have also suggested that these genera have morphological features in common (CarmelloGuerreiro and Sartori Paoli, 2005). Schinus and Lithrea present a remarkably friable exocarp, while the exocarp of Mauria does not easily separate from the mesocarp (Pell et al., 2011). Lithrea and Mauria have a mesocarp with secretory ducts that form a compact, parallel arrangement (Carmello-Guerreiro, 1996), whereas the secretory ducts in Schinus are arranged randomly, close to the endocarp (Carmello-Guerreiro and Sartori Paoli, 2002). Also, Schinus presents endocarp composed of four discrete cell layers, where the three inner layers are formed from palisade-like sclereids. In contrast, Mauria has an endocarp composed of two or three discrete cell layers of thin-walled parenchyma. In Schinus, Lithrea and Mauria the outermost layer is crystalliferous (Wannan and Quinn, 1990). The ovule traits also seem to be informative in characterizing these genera, in which Schinus and Mauria have bitegmic ovules, but Mauria has a funiculus subapically or laterally attached, whereas in Schinus the funiculus is subapically attached (Bachelier and Endress, 2009; Carmello-Guerreiro and Sartori Paoli, 1999; Copeland, 1959). In contrast, Lithrea has unitegmic ovules, a rare trait in the family, and the funiculus is basally attached (Bachelier and Endress, 2009; Carmello-Guerreiro and Sartori Paoli, 2005). Additionally, the anatomical investigation of the petiolar parenchyma indicates that 
Mauria and Lithrea share homogeneous parenchyma (Fig. 3E), a character state also observed in the simple-leaved lineage of Schinus. Additionally, Mauria presents petioles with a medullar bundle (Fig. $5 \mathrm{H}$ ), an unsual character state that was not observed in Lithrea and Schinus. Further anatomical studies using a broader sampling of Mauria species could shed greater light on the utility of this feature as a possible synapomorphy for this genus.

In regard to the infrageneric classification of Schinus, Barkley $(1944,1957)$ divided the genus into $S$. subg. Schinus, in which he included plants with pinnately compound leaves and paniculate inflorescences, and $S$. subg. Duvaua, which is characterized by simple leaves and pseudoracemes. However, previous studies had already pointed out that the characters defining these two subgenera are not always consistent (e.g. Fleig, 1987). Our phylogenetic analysis demonstrates that $S$. subg. Schinus is not monophyletic, nor is $S$. subg. Duvaua sect. Duvaua or $S$. subg. Duvaua sect. Pseudoduvaua. Our results also show that characters traditionally used in the infrageneric circumscriptions are mostly plesiomorphic or homoplastic. The present study demonstrates that almost all infrageneric categories proposed by Barkley $(1944,1957)$ are polyphyletic, suggesting that a new circumscription for groups within Schinus is needed.

The phylogenetic study of Schinus demonstrates a strong congruence between phylogeny and geography, and suggests that vicariance (Sanmartín, 2014) may have played a major role in the biogeographical processes that have led to the current distribution of its species. In addittion, our analyses show that Schinus comprises eight clades that are both well supported (all clades except clade 4; PP 0.79) and geographically structured (Fig. 6A), and are also relatively well characterized by morphology. Based on these results, we here recognize these eight clades as formal sections of Schinus, referred here as $S$. sect. Terebinthifolia (clade 1), S. sect. Schinus (clade 2), S. sect. Lentiscifolia (clade 3), S. sect. Atlantica (clade 4), S. sect. Pilifera (Clade 5), S. sect. Montana (clade 6), S. sect. Duvaua (clade 7) and S. sect. Myrtifolia (clade 8).

Marchand (1869) had also divided the genus in sections (viz., S. sect. Schinus and S. sect. Duvaua). This circumscription was closely followed by Barkley (1944, 1957), who preferred treating these taxa at the subgeneric rank rather than the sectional (viz., S. subg. Schinus and S. subg. Duvaua). Thus, Marchand's sections and Barkley's subgenera are equivalent and differ from the infrageneric classification proposed herein.

Schinus sect. Terebinthifolia, S. sect. Schinus and S. sect. Lentiscifolia (clades 1, 2 and 3 , respectively) have compound leaves and paniculate 
inflorescences, character states that proved to be plesiomorphic (Fig. 4A). The anatomical features of the leaf, such as the petiolar parenchyma (Fig. 5A-C), seem to have strong phylogenetic signal, and this feature in particular is useful in characterizing some of the main lineages in Schinus. The evolutionary mapping of petiolar parenchyma (Fig. 3E) reveals that spongy parenchyma (Fig. $5 \mathrm{C}$ ) is probably a synapormorphy for $S$. sect. Terebinthifolia, but spongy parenchyma on the abaxial surface and palisade on the adaxial surface type (Fig. 5A), and the homogeneous type (Fig. 5B) are homoplastic characters. Nevertheless, the former type of parenchyma is useful in characterizing $S$. sect. Schinus and S. sect. Lentiscifolia (Fig. $6 \mathrm{~B}$ ), whereas the latter type is characteristic of the simple-leaved lineage (clades 4-8, Fig. 6B). This study also confirms the polyphyly of $S$. subg. Duvaua sect. Duvaua. Members of this section are found in five different lineages here (clades 4-8). The accessions of $S$. polygama, the type of this section, are nested within clade 7 (S. sect. Duvaua), along with the accessions of $S$. latifolia, the type of the $S$. subg. Duvaua sect. Pseudoduvaua, which is also polyphyletic because its taxa are placed in three different lineages (clades 6-8).

Schinus sect. Atlantica (clade 4) is composed entirely of taxa from S. subg. Duvaua sect. Duvaua, and its species are restricted to Atlantic Forests Domain (Fig. $6 \mathrm{~B})$. In our molecular trees, this clade is poorly supported, but the morphological study provides evidence from the pattern of stomata on the adaxial surface of leaf that is useful in characterizing this clade as a section. Members of $S$. sect. Atlantica have scattered and inconspicuous stomata, whereas those of $S$. sect. Pilifera have conspicuous stomata aggregated along the midribs. A more comprehensive Schinus sampling will help to confirm the taxonomic utility of this character. The recognition of $S$. sect. Atlantica is also supported by the overall pattern of geographic distribution. The phylogenetic trees generated here in are structured both geographically and ecologically, with taxa from each clade limited mostly to particular geographic areas and vegetation types. For example, the species of clade 4 occur in mesic vegetations in the Atlantic Forests, whereas those of clade 5 inhabit arid vegetations such as Monte, Chaco, and dry inter-Andean valleys (Fig. 6A). Of special interest is the placement of two varieties heretofore treated in the same species. Schinus engleri var. uruguayensis, from the arid Monte Serrano vegetations of Uruguay and south Brazil, is placed among other arid taxa in clade 5 , while the conspecific $S$. engleri var. engleri is placed in clade 4, among the other Atlantic Forest taxa (Fig. 2). Despite the treatment of these two varieties in the same species, ecology, geography, and morphology all support the transfer of $S$. engleri var. uruguayensis to $S$. sect. Pilifera. The strong correlation between the phylogeny and geography also provides evidence 

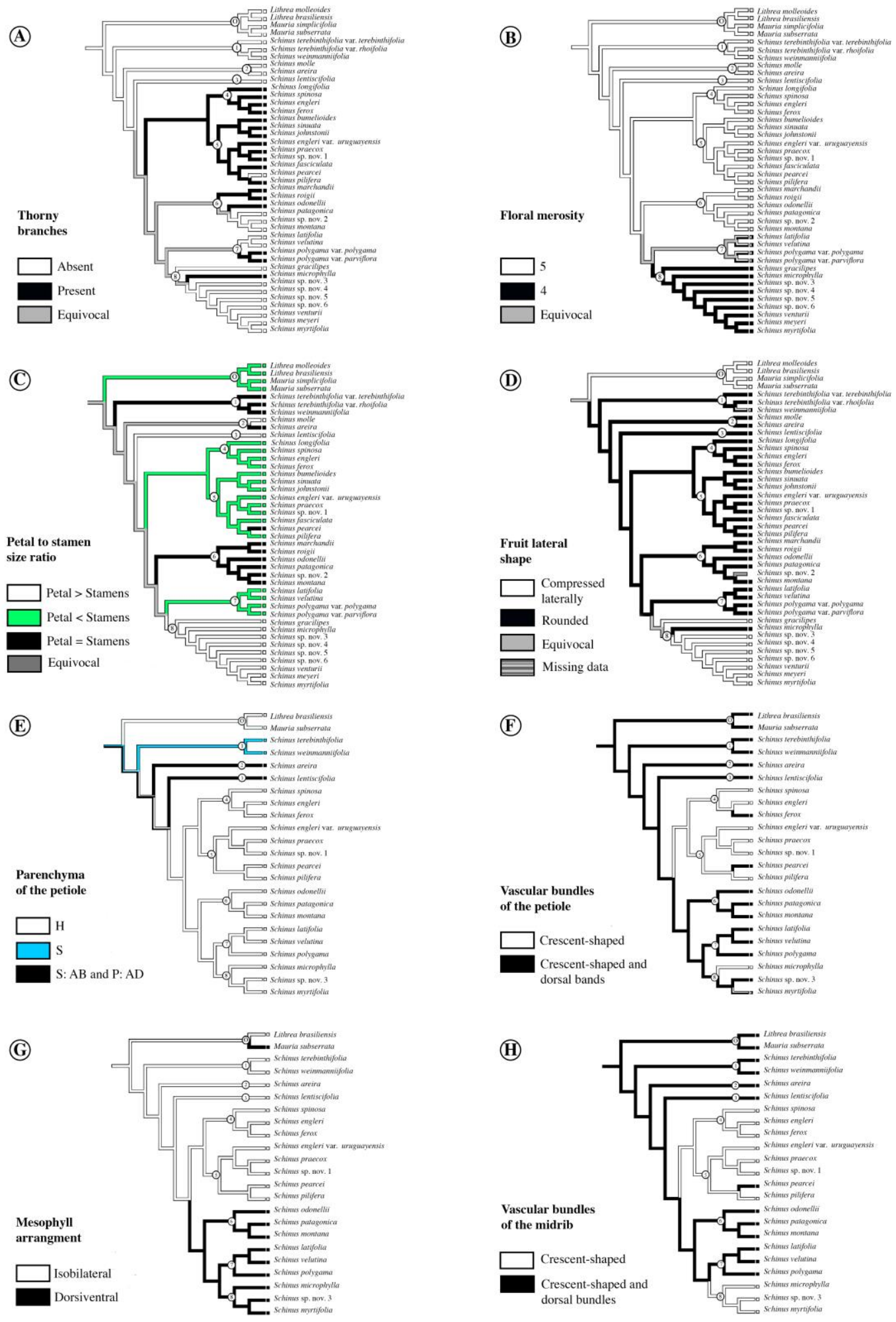

Fig. 3. Reconstruction of morphological characters onto a Bayesian tree. Schinus taxa with multiple vouchers were reduced to one terminal. Outgroup sampling was restricted to the closest related genera to Schinus (Lithrea and Mauria). A: Thorny branches; B: Floral merosity (5 - Pentamerous; 4 - Tetramerous); C: Petal to stamen size ratio; D: Fruit lateral shape, $E$ : Parenchyma of the petiole $(\mathrm{H}$ - Homogeneous; $\mathrm{S}$ - Spongy; $\mathrm{AB}$ - abaxial surface; $\mathrm{P}$ - Palisade; $A D$ - adaxial surface); F: Vascular bundles of the petiole; G: Mesophyll arrangement; $H$ : Vascular bundles of the midrib. Labeled nodes represent the main clades in Schinus and are discussed in the text. 
(A)

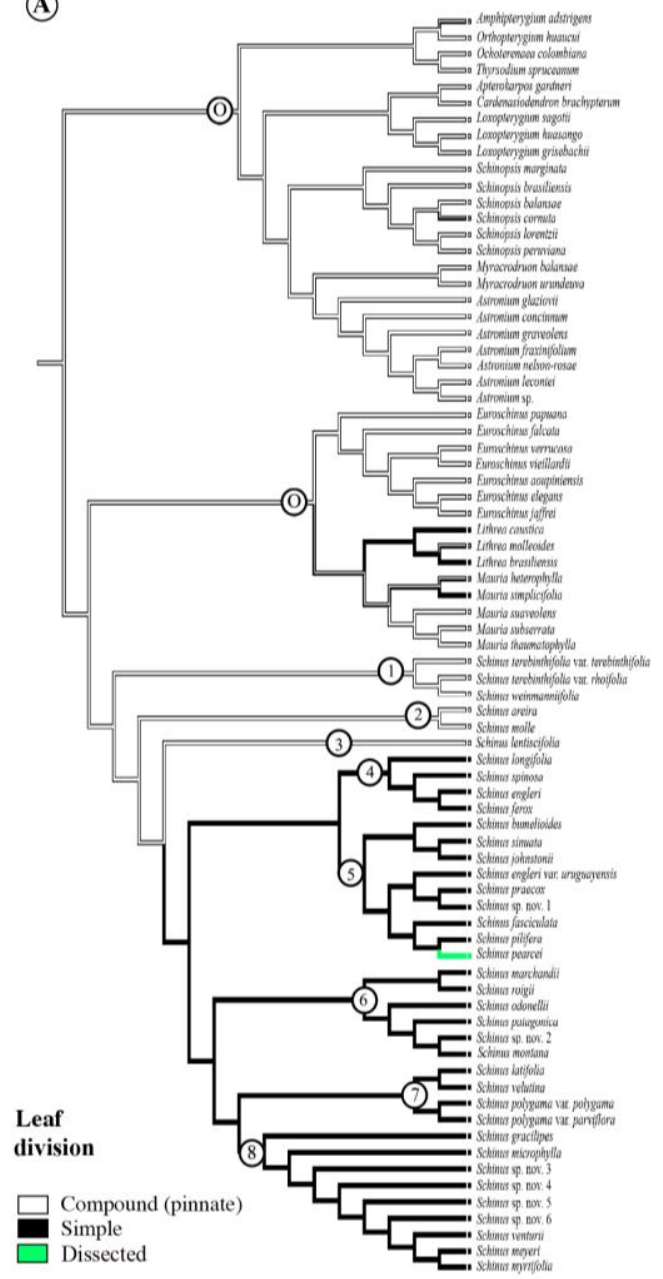

(B)

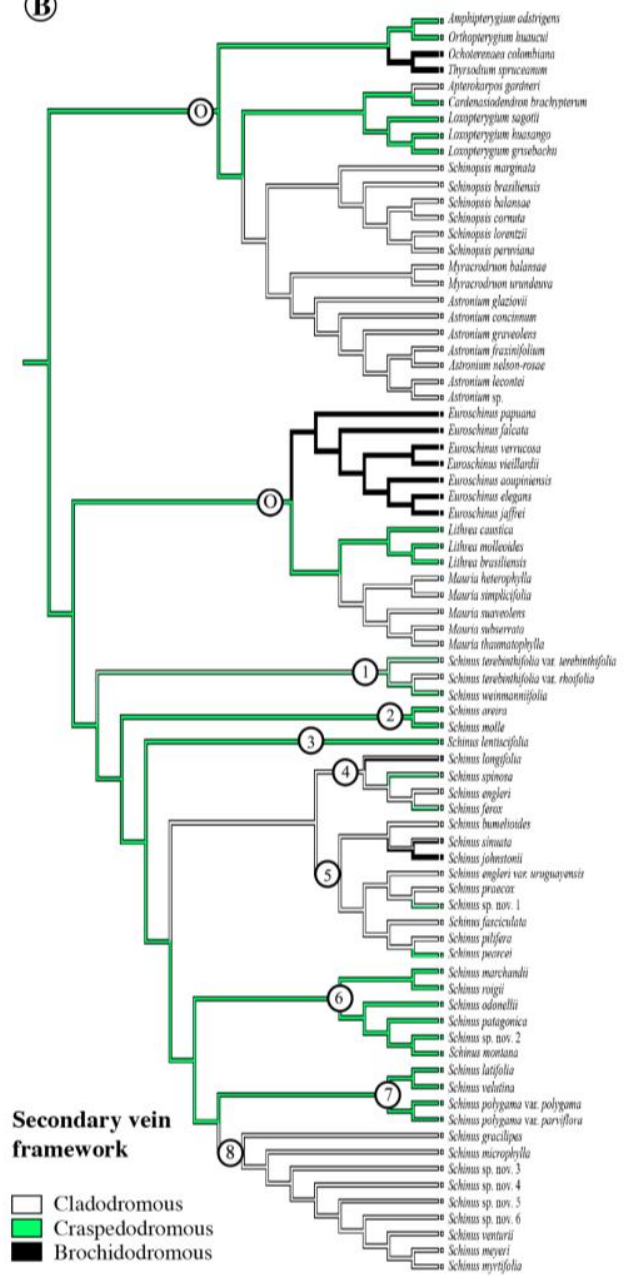

Fig. 4. Reconstruction of morphological characters onto a Bayesian tree. Schinus taxa with multiple vouchers were reduced to one terminal. Complete outgroup sampling. A: Leaf division; B: Secondary vein framework. Labeled nodes represent the main clades in Schinus and are discussed in the text.

for one putative cryptic species (Schinus sp. nov. 1), since a sample previously identified as $S$. longifolia is placed among other arid taxa in clade 5 , suggesting a similar pattern to that observed in S. engleri var. uruguayensis. This highlights the importance of geographic distribution as an additional line of evidence in characterizing clades in Schinus, particularly in Schinus sect. Atlantica. Schinus sect. Pilifera (clade 5) also inlcudes several taxa from Barkley's S. subg. Duvaua sect. Duvaua, but unlike those in $S$. sect. Atlantica, the species from clade 5 are distributed across a greater range of arid vegetation types found in southern South America (Fig. $6 A)$. All taxa of this section have simple leaves and thorny branches with exception of $S$. pearcei, which has unarmed branches and dissected leaves. The morphological reconstructions demonstrated six possible character-state reversals in $S$. pearcei (Fig. 3A, 3C, 3F, 3H, 4A, 4B) relative to the character states found in the compoundleaved grade. Among these traits, leaf division plays an important role in the 
circumscription of Schinus. Traditionally, leaves of S. pearcei have been classified as compound, and as consequence this species was placed in $S$. subg. Schinus (Barkley, 1944, 1957; Engler, 1881). However, the position of $S$. pearcei has been subject of discussion because its unusual branches may bear either simple or compound leaves (Fleig, 1987). Here, we follow the concept of Geeta et al. (2011) by classifying the leaves of $S$. pearcei as "dissected" because their blade is simple but deeply lobed, with lobe sinuses ranging from greater than one-third to nearly all the way to the midrib. Lobed and complex leaves may possess physiological properties that are beneficial under specific environments (Geeta et al., 2011). Studies of leaf physiognomy have suggested that a community having a high proportion of leaves with dissected margins is related to low mean annual temperature and low precipitation (Peppe et al., 2011; Royer et al., 2005). Schinus pearcei occurs in Bolivia, Chile and Peru, in conditions of relatively low temperature and precipitation, whereas the remaining species of this section occur also in arid areas with low precipitation but warmer temperatures. This pattern suggests that the change from simple to dissected leaves could be related to environmental convergence. However, studies have demonstrated that assumptions of convergence (e.g., correlations between leaf physiognomic traits and climate) has low confidence when tested in a comparative phylogenetic framework (Hinojosa et al., 2010; Little et al., 2010). In some cases, certain correlations could be explained by exaptation and subsequent adaptive changes. The presence of seemingly non-random phylogenetic signal throughout leaf physiognomic data leads to leaf trait-climate relationships that are driven both by adaptive evolution and phylogenetic history, and the adaptive signal is especially weak for the most widely used variable, presence of teeth (Little et al., 2010).

Taxa of Schinus sect. Montana (clade 6), S. sect. Duvaua (clade 7) and S. sect. Myrtifolia (clade 8) are composed of armed and unarmed taxa from both $S$. subg. Duvaua sect. Duvaua and S. subg. Duvaua sect. Pseudoduvaua. Ancestral state reconstructions indicate that most of morphological characters are homoplastic in these clades, they can be useful in characterizing some clade when used in combination (Fig. 6B). For instance, S. sect. Montana and S. sect. Duvaua are mostly characterized by a combination of character states (e.g. secondary vein framework, ratio of petal to stamen sizes, merosity), whereas $S$. sect. Myrtifolia is better defined by putative synapomorphies (tetramerous flowers and laterally compressed fruits). 


\subsection{Morphological character evolution}

The reconstruction of morphological ancestral states in Schinus allows for a reevaluation of features traditionally used in the classification of the genus. These reconstructions have identified putative synapomorphies for $S$. sect. Myrtifolia (i.e., tetramerous flowers and laterally compressed fruits), traits in other clades generally exhibit high levels of homoplasy. Therefore, clades recovered in the phylogenetic analyses are diagnosed largely on the basis of a combination of characters. Below, we discuss some of the vegetative and floral traits that seem to be relevant to the evolutionary history of Schinus.
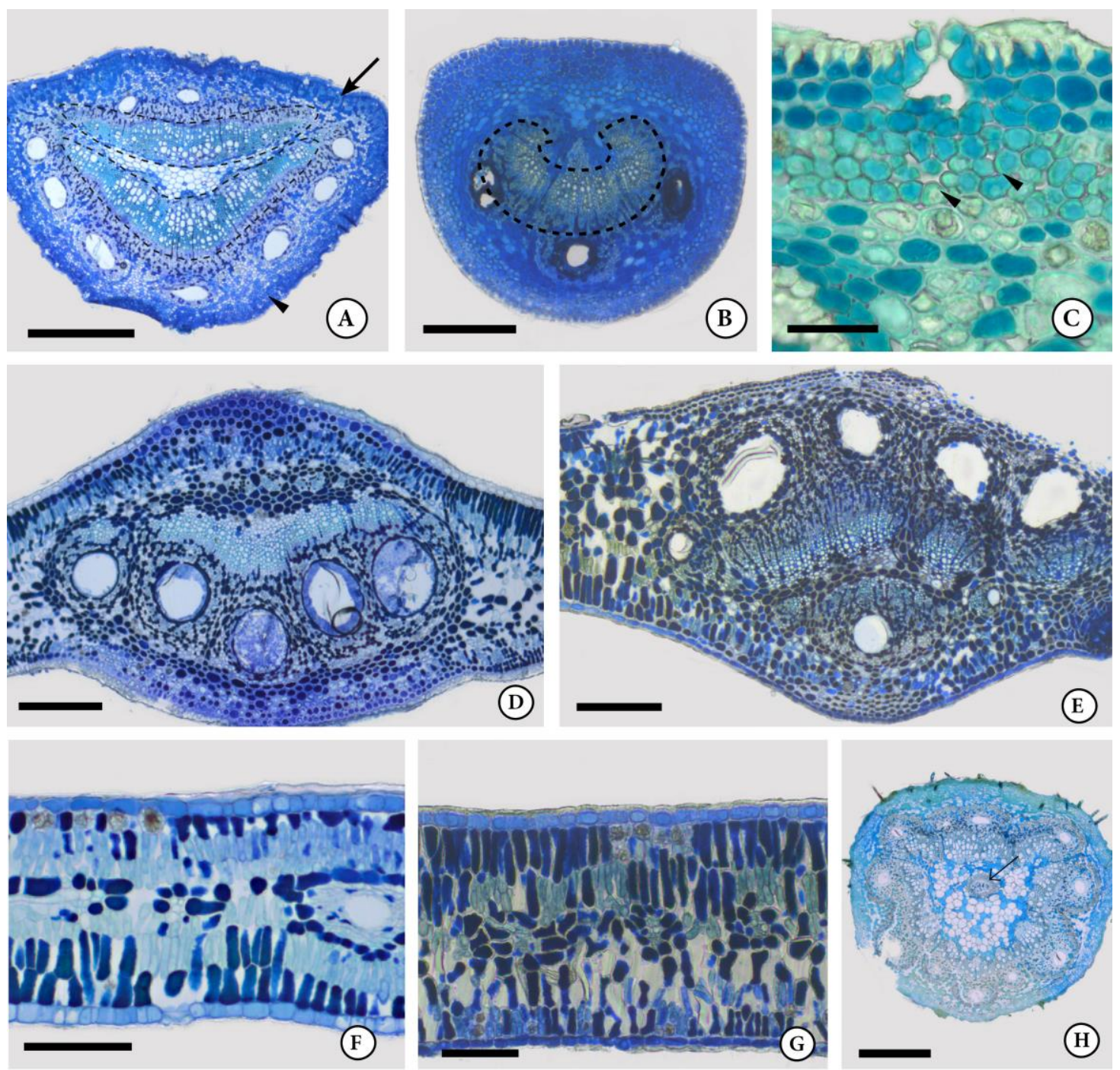

Fig. 5. A - Schinus areira: arrow indicates palisade parenchyma on adaxial side and arrowhead indicates spongy parenchyma on abaxial side; hatched lines indicate crescent-shaped and dorsal vascular bundles of the petiole. B Schinus engleri: homogeneous parenchyma on both sides; hatched line indicates crescent-shaped vascular bundles of petiole. C - Schinus weinmanniifolia: arrowhead indicates spongy parenchyma of the petiole. D - Schinus engleri: crescent-shaped vascular bundles of the midrib. E. Schinus latifolia: crescent-shaped and dorsal vascular bundles of the midrib. F - Schinus areira: isobilateral mesophyll. G - Schinus latifolia: dorsiventral mesophyll. H - Mauria subserrata: crescent-shaped and dorsal vascular bundles of petiole; arrow indicates medullar bundle. Scale bars: A, $\mathrm{C}, \mathrm{H}=500 \mu \mathrm{m} ; \mathrm{B}, \mathrm{D}, \mathrm{E}=200 \mu \mathrm{m} ; \mathrm{F}, \mathrm{G}=100 \mu \mathrm{m}$. 


\subsubsection{Vegetative traits}

The diversification of bovids from mid-Miocene closely matches the rapid accumulation of spiny plant lineages in the African savanna, suggesting that bovids presented a novel mode of feeding that spread in Africa after the Miocene, selecting for the evolution of spinescence (Charles-Dominique et al., 2016). Studies of spiny plants from East Africa (Young and Okello, 1998; Young et al., 2003) and Europe (Obeso, 1997) demontrated that spiny leaves are much less likely to suffer herbivory by vertebrates than less spiny plants. Surprisingly, studies have also correlated the architectural design of trees and herbivory. Where large browsers are abundant, the survival of trees depends on their ability to deploy defenses, either chemical or structural, such as an arrangement of dense and intricate architecture or a cage architecture. Previous studies showed that trees found in herbivore-rich environments tend to have more cage architecture (Archibald and Bond, 2003; Bond, et al., 2004), and it seems that spines play an important role in contributing to slowing down the herbivore bite rate (Charles-Dominique et al., 2017). However, for most spiny species, spinescence alone is not sufficient to provide efficient protection (CharlesDominique et al., 2017). Noticeably, species of $S$. sect. Pilifera have branches that are often patent or ascending, mostly borne at angles between $90^{\circ}$ and $45^{\circ}$ to the branches from which they arise (Fig. 11B). This branching pattern resembles the cage architecture because of the thorny branches are arranged in two or three axes, expressing a combination of orthotropic, plagiotropic and ageotropic growth patterns. General patterns of plant defence against herbivory can be also observed in South America (Göldel et al., 2016; Gowda and Raffaele, 2004), where the fossil record documents the occurrence of browsing mammals, especially before the late Eocene (MacFadden, 2000). For instance, in northern Patagonia, where spiny shrubs are common, Gowda and Raffaele (2004) demonstrated that plants resprounting after fire respond to the increased risk of herbivory by increasing their investments in defensive traits (such as spine length) probably in response to an increase in terrestrial herbivores that are favored the greater availability of fast growing forage species colonizing or re-sprouting in recently burned areas (Veblen et al., 1992). Since several Schinus species occur in spiny shrub areas of southern South America, in particular taxa of $S$. sect. Pilifera, the presence of structures such as thorns and cages is likely correlated with anti-herbivore defence. Future investigations in South America could integrate phylogenetic reconstructions, dating, and species distribution models to explore the interaction between abiotic environment, spiny plant species, and herbivory. By contrast, spinescent species are rare in forests and negatively associated with its mammalian fauna (Charles-Dominique et al., 2016), a trend 
exhibited by the species of $S$. sect. Myrtifolia, which occur in montane cloud forests and are devoid of thorny branches (Fig. 10B-C).

\subsubsection{Floral traits}

Overall, flower morphology is uniform throughout Schinus species, although the ratio of petal to stamen sizes (Fig. 3C), a homoplastic character, and floral merosity (Fig. 3B) are useful for diagnosing some sections. For example, species of $S$. sect. Terebinthifolia and $S$. sect. Montana have petals that are as long as the stamens, while species of $S$. sect. Atlantica, S. sect. Pilifera (except for S. pearcel) and $S$. sect. Duvaua are characterized by petals that are shorter than the stamens, and species of $S$. sect. Myrtifolia and S. sect. Lentiscifolia have petals that are longer than the stamens. Species of $S$. sect. Schinus have petals that may be as long or longer than the stamens. With regard to floral merosity, the species of most sections have pentamerous flowers (Figs. 3B, 6B), with the exception of $S$. sect. Myrtifolia and S. sect. Duvaua, which have tetramerous flowers and tetramerous and pentamerous flowers, respectively. The evolutionary mapping of this character suggests that the presence of tetramerous flowers is probably a synapomorphy of $S$. sect. Myrtifolia. Studies have shown a correlation between the differentiation of floral traits and pollinator preference. Flower size is likely to be positively correlated to pollinator attraction, and thus these floral phenotypes are often assumed to have resulted from selection by pollinators (Barrett \& Harder, 1996; Ashman and Morgan, 2004). In addition, a size match between flowers and their pollinators may be required to assure the precise pollen placement on the pollinator's body, facilitating outcrossing (Li et al., 2015). The main lineages of Schinus have different ratios of petal to stamen sizes and this trait may be correlated to the pollinator communities associated with the areas in which each major lineage occurs. In a study of floral-trait variation in two Chinese populations of Trollius ranunculoides (Ranunculaceae), a species from alpine and subalpine meadows, demonstrated that alpine populations, where flies are the predominant pollinators, have more petals per flower but smaller flowers, whereas subalpine population, visited mostly by bees, have larger flowers (Zhao and Huang, 2013). Similarly, in a study of Scandinavian plant communities, pollinator assemblages tend to change from bee domination at lower altitudes to fly domination at higher alpine areas (Lázaro et al., 2008). A similar scenario is observed in species of $S$. sect. Myrtifolia, a section comprising taxa that mostly occur at high elevation in areas of montane cloud forests. Its species present flowers that are relatively smaller than those of Schinus species from lower elevations, and have fewer but longer petals compared to their stamens. However, S. lentiscifolia, with smaller flowers, co- 


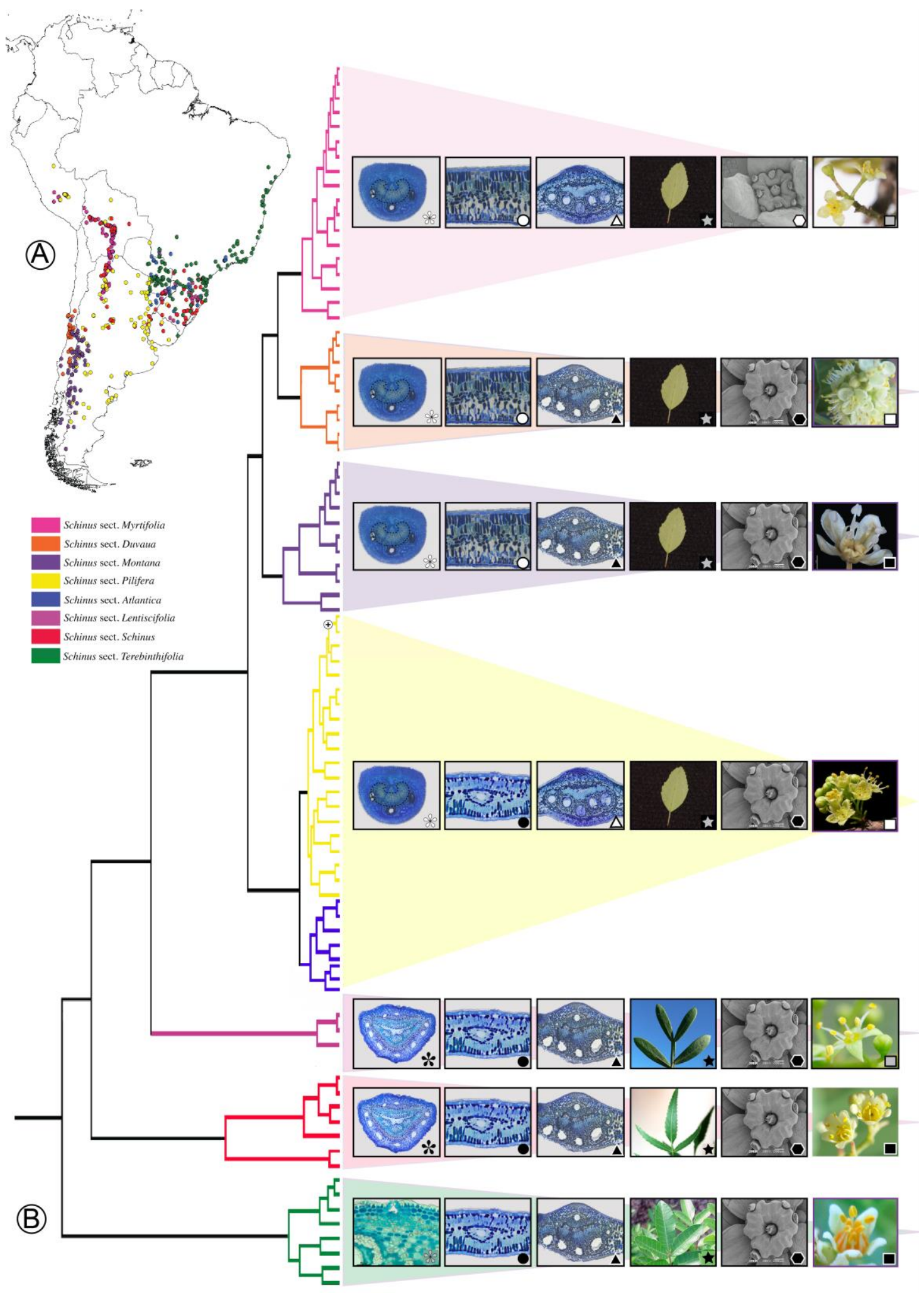

Fig. 6. A: Map depicting the geographic distributions of species from the eight sections of Schinus, each section indicated with a different color according to the caption below the map. B: The Schinus phylogeny, with key morphological features highlighted in each section. The symbols used here follow the sequence of character states listed in table 4: White, grey and black flower symbols correspond to character states of the petiolar parenchyma (character 12); black and white circle symbols correspond to character states of the mesophyll arrangement (character 14); white and black triangle symbols correspond to character states of the midrib vascular bundles (character 15); black and white star symbols correspond to character states of the leaf organization (character 2); black and white polygon symbols correspond to character states of floral merosity (character 7); and gray, white and black square symbols correspond to character states of petal to stamen size ratio (character 8). Most pictures representing character states taken from other plates presented herein. Circle in the yellow part of phylogenetic tree indicates reversals in $S$. pearcei relative to the character states found in the compound-leaved grade. 
occurs with other species having relatively larger flowers, suggesting that such differences may not always be a consequence of pollinator preference in Schinus. Assumptions regarding convergence of floral adaptations should be considered cautiously, since pollination studies in the genus are limited largely to $S$. terebinthifolia (Cesário and Gaglianone, 2013; Lenzi and Orth, 2004; Somavilla et at., 2010). Studies scrutinizing the convergence between floral traits and pollinator preference suggest that strong pollinator preference for certain floral phenotypes in a population may not automatically translate into significant differences in female reproductive success among these phenotypes (Totland, 2004). Yet, another study testing pollination syndrome hypotheses on a broad scale (Ollerton et al., 2009) showed that, for approximately two-thirds of plant species analyzed, the most common pollinator could not be successfully predicted by assuming that each plant species belongs to the syndrome closest to it in phenotype space. In summary, studies of plant-pollinator interaction have warned against the use of single measures of ecological generalization in addressing questions regarding the pollination syndrome concept (Lázaro et al., 2008; Ollerton et al., 2009), and instead suggest a large scale approach using community comparisons to assess pollination syndromes, as well as investigations of relationships between ecological and evolutionary specialization in plant-pollinator (and antagonists) interactions that may provide a better understanting of the pollinator ability to influence the evolution of floral phenotypes within certain phylogenetic constraints.

\subsection{Taxonomic treatment}

The names of the sections recognized here are based on the most widley known species from each clade, with the exception of $S$. sect. Duvaua, which has taxonomic priority in clade 7 and $S$. sect. Atlantica, which is so named because its species occur in the Atlantic Forest Domain.

\subsubsection{Key to sections of Schinus}

1 Leaves pinnately compound 2

Leaves simple, rarely dissected .............................................................. 4

2 Leaflets grayish-green, paripinnate; petals longer than stamens; plants widespread in South Brazil, Argentina, Paraguay and Uruguay S. sect. Lentiscifolia 
- Leaflets green, imparipinnate; petals as long as stamens, sometimes longer than stamens ....

3 Leaflets lanceolate or linear; plants of South Brazil extending into Uruguay, East Paraguay and Northeast Argentina, and along the Andes in Bolivia, Argentina and Peru

S. sect. Schinus

- Leaflets obovate, ovate, oblong or elliptic; native to Brazil, Paraguay and Northeast Argentina S. sect. Terebinthifolia

4 Plants with flowers tetramerous or pentamerous (but not mixed in the same inflorescence or individual) ..... 5

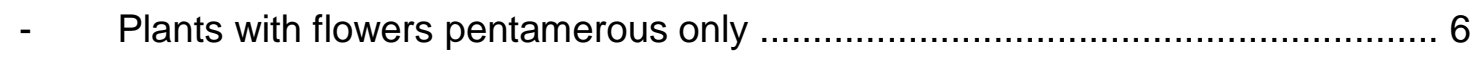

5 Leaves with secondary veins cladodromous; plants with flowers 4-merous; petals longer than stamens; fruiting branches lax; fruit often laterally compressed; fruits red, pink or pinkish-red; plants of the montane cloud forests of Peru, Bolivia and Argentina, sometimes in Peruvian and Bolivian pre-Puna, Puna and dry inter-Andean valleys

S. sect. Myrtifolia

- Leaves with secondary veins craspedrodomous; plants with flowers 4-merous or 5-merous; petals shorter than stamens; fruiting branches congested; fruit rounded, not laterally compressed; fruit purple or dark purple; plants of sclerophyll forests of central and south Chile

S. sect. Duvaua

6 Leaves with secondary veins craspedrodomous; inflorescences pseudoracemes; petals as long as stamens; plants of the Argentinean and Chilean pre-Puna and Patagonia

S. sect. Montana

- Leaves with secondary veins often cladodromous, sometimes craspedodromous or brochidodromous; inflorescences thyrsoids, panicles or pseudoracemes; petals shorter than stamens, or if petals as long stamens, then leaves dissected; plants occurring in other vegetation types in southeastern and southern South America 7

7 Branches elongate and often pendulous; leaves not heteroblastic (with similar shape and size in adult and young individuals); plants of riparian forests or mixed ombrophilous forests (with Araucaria) of South and Southeastern Brazil, East Paraguay, Northeast Argentina extending into Uruguay ... S. sect. Atlantica Branchlets often patent or ascending (mostly borne at angles between $45^{\circ}$ and $90^{\circ}$ to the branches from which they arise), if branchlets elongate and pendulous, then leaves dissected; leaves heterobalstic (with different shape and size in adult and young individuals); plants of arid vegetation types in Argentina, Paraguay, Uruguay and Bolivia S. sect. Pilifera 


\subsubsection{Novel phylogenetic sectional classification of Schinus}

Schinus sect. Atlantica Silva-Luz \& Pirani, sect. nov. - Type: Schinus longifolia (Lindl.) Speg. (Duvaua longifolia Lindl.).

Schinus subg. Duvaua (Kunth) F.A. Barkley pro parte, Brittonia 5(2): 165. 1944, syn. nov. Duvaua Kunth, Ann. Sci. Nat. (Paris) 2: 340. 1824. Schinus subg. Duvaua sect. Duvaua F.A. Barkley pro parte, Brittonia 5(2): 165. 1944, syn. nov. Type: Schinus polygama (Cav.) Cabrera (Amyris polygama Cav.).

Diagnosis. Differs from S. sect. Schinus, S. sect. Terebinthifolia and S. sect. Lentiscifolia because of its simple leaves (vs. pinnately compound leaves). Differs from S. sect. Myrtifolia and S. sect. Montana because of its flowers with petals shorter than stamens (vs. petals longer than stamens and petals as long as stamens, respectively). Differs from $S$. sect. Duvaua because of its leaves with secondary vein often cladodromous, sometimes craspedodromous and brochidodromous, and pentamerous flowers (vs. leaves with secondary veins craspedodromous, and pentamerous and tetramerous flowers). Resembles to $S$. sect. Pilifera because of the thorny branches bearing simple leaves, and petals shorter than stamens, but differs because of its elongate and pendulous branches, and leaves with similar shape and size in adult and young individuals (vs. branchlets often patent or ascending, and leaves with different shape and size in adult and young individuals).

Schinus sect. Atlantica comprises five species distributed mostly in riparian forests or mixed ombrophilous forests (with Araucaria) of south and southeast Brazil. They are also found in east Paraguay, northeast Argentina extending into Uruguay. Barkley $(1944,1957)$ recognized taxa of this section as part of $S$. subg. Duvaua sect. Duvaua. All species of this section have thorny and pendulous branches and simple leaves with scattered and inconspicuous stomata on adaxial surface. The inflorescences are often pseudoracemes, rarely thyrsoids, bearing pentamerous flowers. The flowers have petals shorter than stamens, and the fruits are globose, red, dark red or purple (Figs. 6B, 7). Also, the anatomical study of leaf evidenced an isobilateral mesophyll (Fig. 5F), a vascular tissue of the midrib composed by crescent-shaped bundles and the petiole with homogeneous parenchyma (Fig. 5B). In this section there are problems in species delimitation, especially between $S$. engleri and $S$. ramboi, and a new taxonomic revision will be relevant to identify additional morphological traits and contribute to improvement of species circumscription. The recognition of consistent characters can also contribute to studies of systematics and macroevolution of galls, particularly those associated or restricted to Schinus sect. 

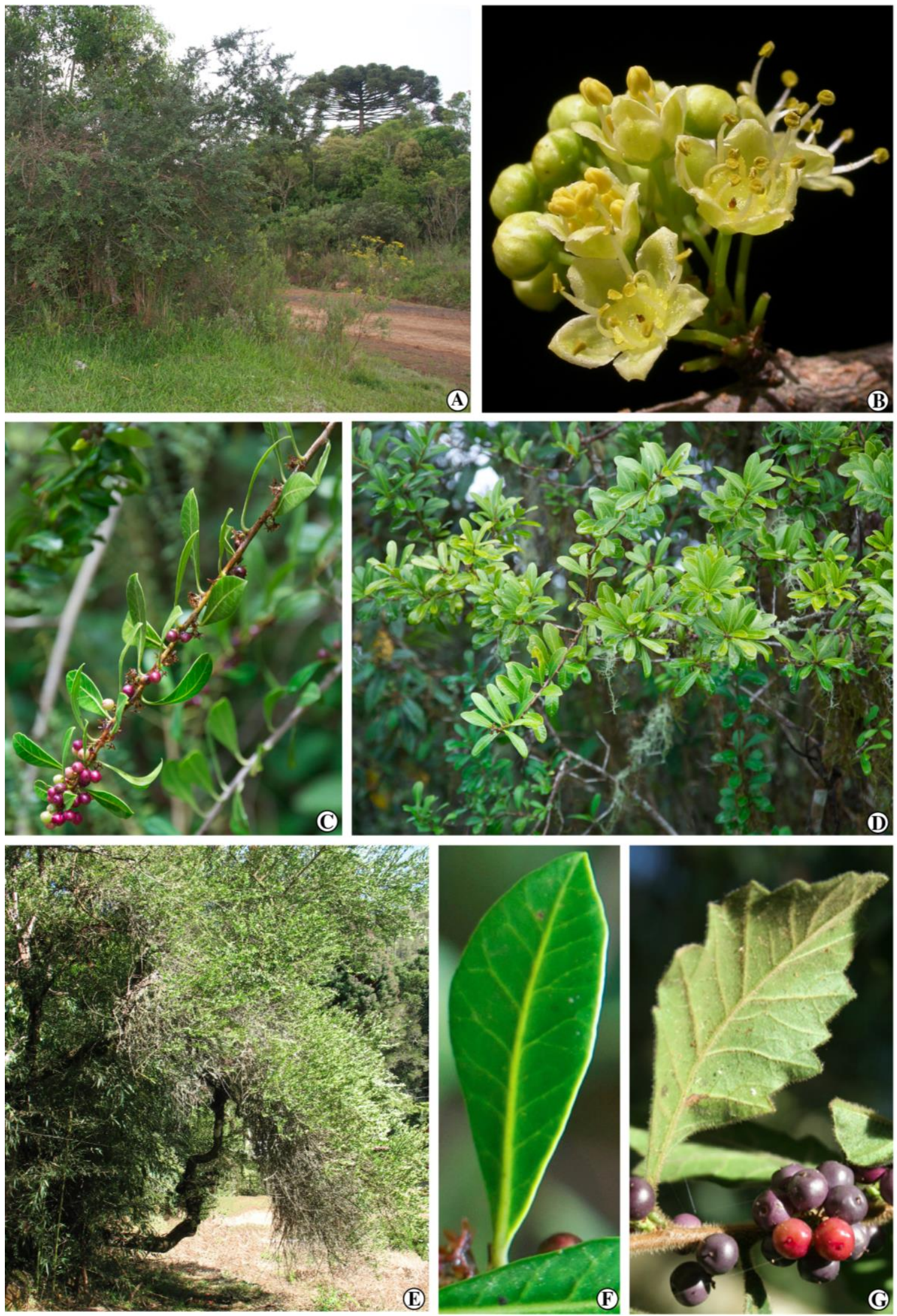

Fig. 7. Taxa of Schinus sect. Atlantica: A. Habit of Schinus spinosa. B. Staminate inflorescence of Schinus longifolia. C-D. Fruiting branches of Schinus engleri. E. Habitat of Schinus ramboi. F. Leaf of Schinus ramboi showing the cladodromous secondary veins. G. Leaf of Schinus spinosa showing the craspedodromous secondary veins. Pictures A and C-F, C.L. Silva-Luz; B, M. Bonifacino; G. E.L.H. Giehl. 
Atlantica (Burckhardt and Basset, 2000; Burckhardt and Queiroz, 2017; Dias et al., 2013ab; Moreira et al., 2012; Nuñez, 1997).

Taxa list. Schinus engleri F.A. Barkley, S. ferox Hassler, S. longifolia (Lindl.) Speg. var. longifolia, S. longifolia (Lindl.) Speg. var. paraguariensis (Hassler) F.A. Barkley, S. ramboi F.A. Barkley, S. spinosa Engl.

Schinus sect. Duvaua Marchand emend. Silva-Luz, Rev. Anacardiac. 164. 1869. Schinus subg. Duvaua (Kunth) F.A. Barkley pro parte, Brittonia 5(2): 165. 1944, syn. nov. Duvaua Kunth, Ann. Sci. Nat. (Paris) 2: 340. 1824. Schinus subg. Duvaua sect. Duvaua F.A. Barkley pro parte, Brittonia 5(2): 165. 1944, syn. nov. - Type: S. polygama (Cav.) Cabrera (Amyris polygama Cav.).

Schinus subg. Duvaua sect. Pseudoduvaua F.A. Barkley pro parte, Brittonia 5(2): 179. 1944, syn. nov. - Type. S. latifolia (Gillies ex Lindl.) Engl. (Duvaua latifolia Gillies ex Lindl.).

Diagnosis. Differs from S. sect. Schinus, S. sect. Terebinthifolia and S. sect. Lentiscifolia because of its simple leaves (vs. pinnately compound leaves). Differs from Schinus sect. Myrtifolia because of its fruits rounded, not laterally compressed, and leaves with secondary veins craspedodromous (vs. fruits laterally compressed and leaves with secondary veins cladodromous). Differs from $S$. sect. Montana because of its flowers with petals shorter than stamens (vs. petals as long as stamens). Differs from $S$. sect. Pilifera and $S$. sect. Atlantica by its leaves with conspicuous marginal secondary veins and individuals bearing pentamerous or tetramerous flowers (vs. inconspicuous marginal secondary veins and individuals bearing only pentamerous flowers).

Schinus sect. Duvaua is formed by three or four species mostly endemic from Chile, with exception of $S$. polygama (Cav.) Cabrera which is the most widespread species in the section, with scattered populations also extending into south, in the Araucanía region, and toward north in Coquimbo region, as well as in Chilean prePuna areas extending into northwestern Argentina, where it is known in Mendoza. Species of this section occur mainly under a Mediterranean climate on Central Chile, in areas known as matorral. This one out of the only five far disjunct phytogeographical regions commonly denominated as chaparral of the world, all of them rich in endemic genera and species (Lomolino et al., 2006). Species of this section can be found in shaded slopes of sclerophyll forests with trees up $25 \mathrm{~m}$ as well as in sunny slopes, in vegetation characterized by xerophytic shrubs associated to annual bromeliads and columnar cactus. Barkley $(1944,1957)$ positioned $S$. 
latifolia and S. velutina in S. subg. Duvaua sect. Pseudoduvaua, and S. polygama in S. subg. Duvaua sect. Duvaua. The circumscription of $S$. sect. Duvaua proposed by Marchand (1869) is nearly similar to ours with exception of $S$. bonplandiana Marchand, a synonym for S. Iongifolia (S. sect. Atlantica). Schinus sect. Duvaua is characterized by unarmed or armed trees or shrubs, leaves with craspedodromous secondary veins, and conspicuous marginal secondary. The number of sepals and petals are not fixed, and is possible to find plants bearing only tetramerous or pentamerous flowers (not mixed in the same individual or inflorescence). The inflorescences are congested pseudoracemes or thyrsoids, and the flowers have petals shorter than stamens. The fruits are globose and often purple (Fig. 8). The anatomical study of leaves in this group evidences a dorsiventral mesophyll (Fig. 5G), a vascular tissue of the petiole and midrib composed by crescent-shaped and dorsal bundles and the petiole with homogeneous parenchyma (Fig. 5A,E). Our phylogenetic study (Fig. 2) provides evidences regarding to recognition of some infraspecific categories within this section. Also, a preliminary study of the $S$. polygama var. parviflora (Marchand) F.A. Barkley pointed out nomenclatural issues that need to be reviewed.

Taxa list. Schinus latifolia (Gillies ex Lindl.) Engl., Schinus velutina (Turcz.) I.M.Johnst. and Schinus polygama (Cav.) Cabrera.

Schinus sect. Lentiscifolia Silva-Luz \& Pirani, sect. nov. - Type: Schinus lentiscifolia Marchand.

Schinus subg. Schinus F.A. Barkley, pro parte, Brittonia 5(2): 184. 1944, syn. nov. Type: Schinus molle L.

Diagnosis. Differs from S. sect. Atlantica, S. sect. Duvaua, S. sect. Montana, S. sect. Myrtifolia, S. sect. Pilifera because of its pinnately compound leaves (vs. simple or dissected leaves). Differs from S. sect. Schinus and S. sect. Terebinthifolia by its paripinnate and grayish-green leaves (vs. imparipinnate and green leaves).

This section comprises only S. lentiscifolia Marchand, a species recognized by Barkley $(1944,1957)$ and Cabrera (1938) as part of S. subg. Schinus or as part of $S$. sect. Schinus (Marchand, 1869; Engler, 1873). It is a common species found in south Brazil and Uruguay in low mountain shrublands-forests of Campos areas, in the Pampas Domain, where it is associated to a xeromorphic vegetation. This species also occurs at low elevation associated to riparian forests, also known in Uruguay as Monte Ribereño. The scattered occurrence of $S$. lentiscifolia in Argentina seems to be restricted to Misiones province, an area under high anthropic pressure. It is possible 

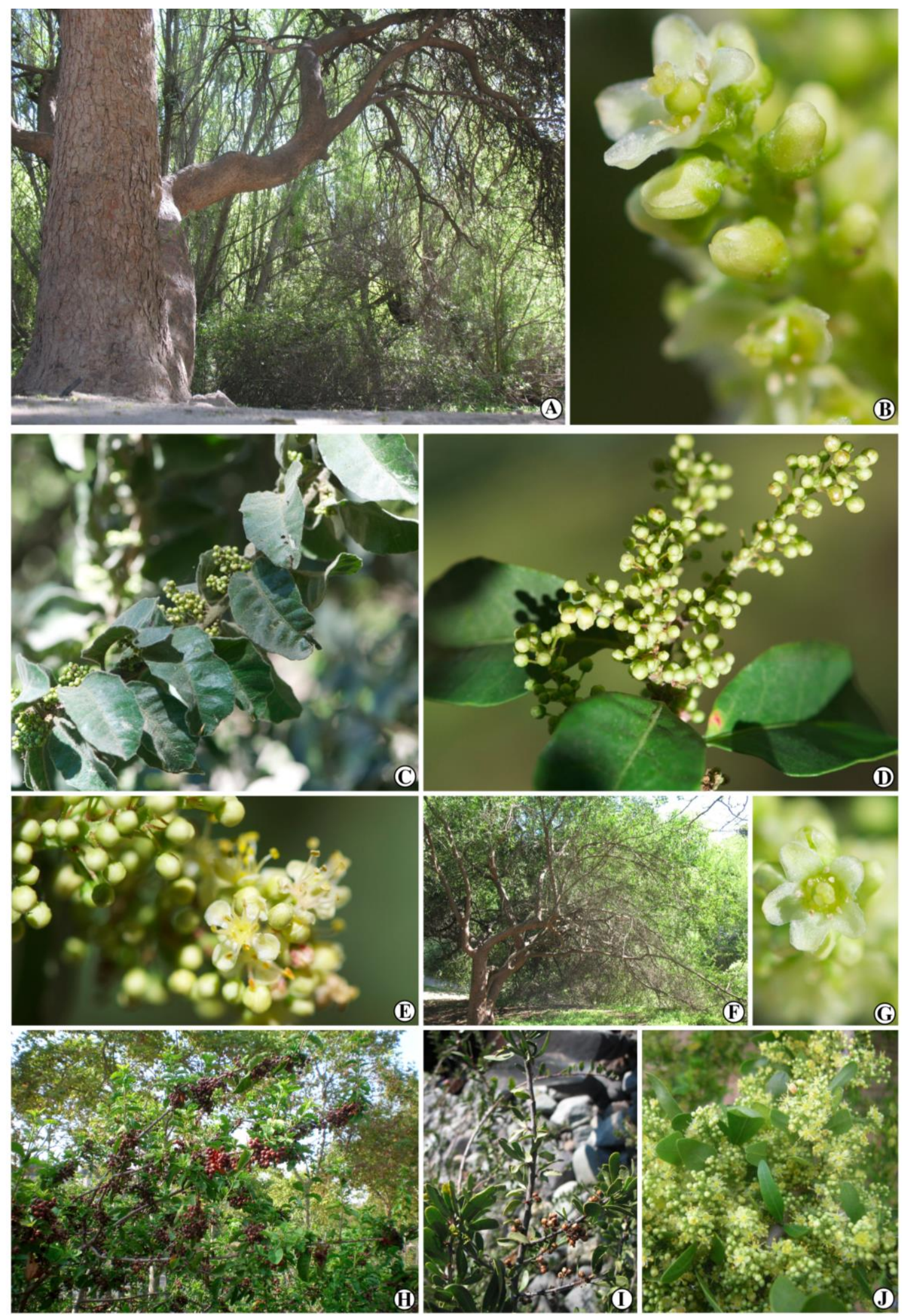

Fig. 8. Taxa of Schinus sect. Duvaua: A. Habit of Schinus velutina. B. Pistillate inflorescence of Schinus latifolia. C. Flowering branch of Schinus velutina. D. Flowering branchlet with staminate inflorescences of Schinus latifolia. E. Staminate inflorescences with tetramerous flowers of Schinus latifolia. F. Habitat of Schinus latifolia. G. Pentamerous flower of Schinus latifolia. H-I. Fruiting branches of Schinus polygama. J. Flowering branches with staminate inflorescences of Schinus polygama. Pictures A-G and I, C.L. Silva-Luz. 
that this species also occurs in eastern Paraguay nearby this vegetation. Schinus lentiscifolia is a shrub or treelet readly distinct from other Schinus species because of its unarmed branches, rachis narrowly winged and grayish-green paripinnate leaves. It has paniculate inflorescences bearing pentamerous flowers. Its fruits are globose, pink and relatively shorter than other Schinus species (Fig. 12F-G). Our anatomical study of leaves evidences an isobilateral mesophyll (Fig. 5F), a vascular tissue of the petiole and midrib composed by crescent-shaped and dorsal bundles (Fig. 5A,E) and the petiole with spongy parenchyma on abaxial side and the palisade parenchyma on adaxial side (Fig. 5A).

Schinus sect. Montana Silva-Luz \& Pirani, sect. nov. - Type: Schinus montana (Phil.) Engl. (Litrea montana Phil.).

Schinus subg. Duvaua (Kunth) F.A. Barkley pro parte, Brittonia 5(2): 165. 1944, syn. nov. Duvaua Kunth, Ann. Sci. Nat. (Paris) 2: 340. 1824. Schinus subg. Duvaua sect. Duvaua F.A. Barkley pro parte, Brittonia 5(2): 165. 1944, syn. nov. Type: Schinus polygama (Cav.) Cabrera (Amyris polygama Cav.).

Schinus subg. Duvaua sect. Pseudoduvaua F.A. Barkley pro parte, Brittonia 5(2): 179. 1944, syn. nov. - Type. Schinus latifolia (Gillies ex Lindl.) Engl. (Duvaua latifolia Gillies ex Lindl.).

Diagnosis. Differs from S. sect. Schinus, S. sect. Terebinthifolia and S. sect. Lentiscifolia because of its simple leaves and pseudoracemose inflorescences (vs. pinnately compound leaves and paniculate inflorescences). Differs from $S$. sect. Atlantica, S. sect. Duvaua and S. sect. Pilifera by its flowers with petals as long as stamens (vs. petals shorter than stamens), and from S. sect. Myrtifolia because of its leaves with secondary veins craspedodromous, and purple and rounded fruits (vs. secondary veins cladodromous, and pink and laterally compressed fruits).

Schinus sect. Montana has approximately six or seven species, occurring often at high elevation in Argentinean and Chilean pre-Puna areas composed by scattered shrubs, and also extending into Patagonia, occurring in shrubby steppes and valleys. Schinus patagonica (Phil.) I.M. Johnst. ex Cabrera is commonly associated to margin of rivers and water streams, and in Chile it occurs in temperate forests with species of Nothofagus and Araucaria. Species of this section were positioned in both $S$. subg. Duvaua sect. Duvaua and $S$. subg. Duvaua sect. Pseudoduvaua (Barkley, 1944, 1957). Schinus sect. Montana includes armed and unarmed shrubs or treelets, with leaves usually coriaceous, concolours and with secondary vein craspedodromous. All species have inflorescences 

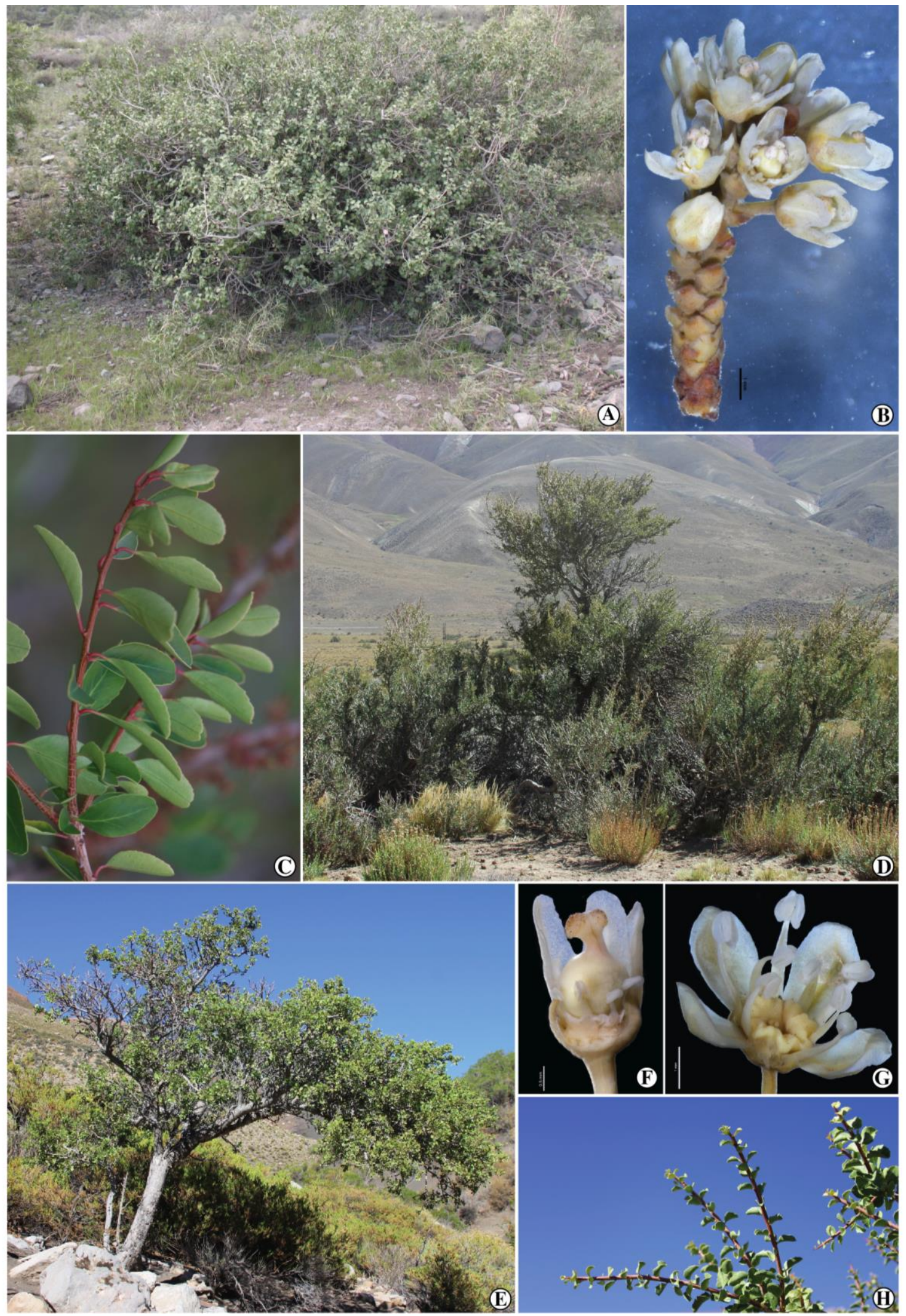

Fig. 9. Taxa of Schinus sect. Montana: A. Habit of Schinus montana. B. Pistillate inflorescence. C.Sterile branch of Schinus patagonica. D. Habitat of Schinus odonellii. E. Habitat of Schinus marchandii. F. Pistillate flower of Schinus montana with two sepals and two petals removed. G. Staminate flower of Schinus montana with one petal and one stamen removed. H. Sterile branches of Schinus marchandii. Pictures A-B and D-H, C.L. Silva-Luz; C, J.D. Mitchell. 
pseudoracemoses bearing pentamerous flowers with petals as long as stamens, and fruits which are globose and purple (Fig. 9). The anatomical study of leaves shows a dorsiventral mesophyll (Fig. 5G), a vascular tissue of the petiole and midrib composed by crescent-shaped and dorsal bundles (Fig. 5A,E) and the petiole with homogeneous parenchyma (Fig. 5B). A taxonomic revision may be helpful in demonstrating that some of the more recently published taxa should be treated as part of the morphological variation range of particular species.

Taxa list. Schinus kauselii F.A. Barkley, S. marchandii F.A. Barkley, S. montana (Phil.) Engl., S. odonellii F.A. Barkely, S. patagonica (Phil.) I.M. Johnst. ex Cabrera and S. roigii Ruiz Leal \& Cabrera.

Schinus sect. Myrtifolia Silva-Luz \& J.D. Mitch., sect. nov. - Type: Schinus myrtifolia (Griseb.) Cabrera (Cybianthus myrtifolius Griseb.).

Schinus subg. Duvaua (Kunth) F.A. Barkley pro parte, Brittonia 5(2): 165. 1944, syn. nov. Duvaua Kunth, Ann. Sci. Nat. (Paris) 2: 340. 1824. Schinus subgenus Duvaua sect. Duvaua F.A. Barkley pro parte, Brittonia 5(2): 165. 1944, syn. nov. Type: Schinus polygama (Cav.) Cabrera (Amyris polygama Cav.).

Schinus subg. Duvaua sect. Pseudoduvaua F.A. Barkley pro parte, Brittonia 5(2): 179. 1944, syn. nov. - Type. Schinus latifolia (Gillies ex Lindl.) Engl. (Duvaua latifolia Gillies ex Lindl.).

Diagnosis. Differs from S. sect. Schinus, S. sect. Terebinthifolia and S. sect. Lentiscifolia because of its simple leaves and fruits laterally compressed (vs. pinnately compound leaves and globose fruits, not laterally compressed). Differs from S. sect. Atlantica, S. sect. Montana and S. sect. Pilifera by its tetramerous flowers (vs. pentamerous flowers). It is distinct from $S$. sect. Duvaua because of its leaves with secondary vein cladodromous, lax pistillate inflorescences and lax fruiting branches (vs. leaves with secondary veins craspedodromous, congested pistillate inflorescences and congested fruiting branches).Schinus sect. Myrtifolia comprises approximately 11 species, which occur mostly in northwerstern Argentina and Bolivia, on rock slopes of the Tucumán-Bolivian forests, besides some species extending into Bolivian Yungas. Also, few taxa occurring on humid rock slopes of the Peruvian and Bolivian pre-Puna, Puna and dry inter-Andean valleys. Schinus sect. Myrtifolia species co-occur with the evergreen Podocarpus and Weinmannia forests as well as in deciduous forests with Alnus acuminata. On steep slopes, at higher elevations Schinus species also occur with remmant and relictual Polylepis forests. At lower elevations (between 1,000-1,500 m), its species occur in Myrtaceae forests, especially with Myrcianthes spp. Schinus sect. Myrtifolia comprises species that were 

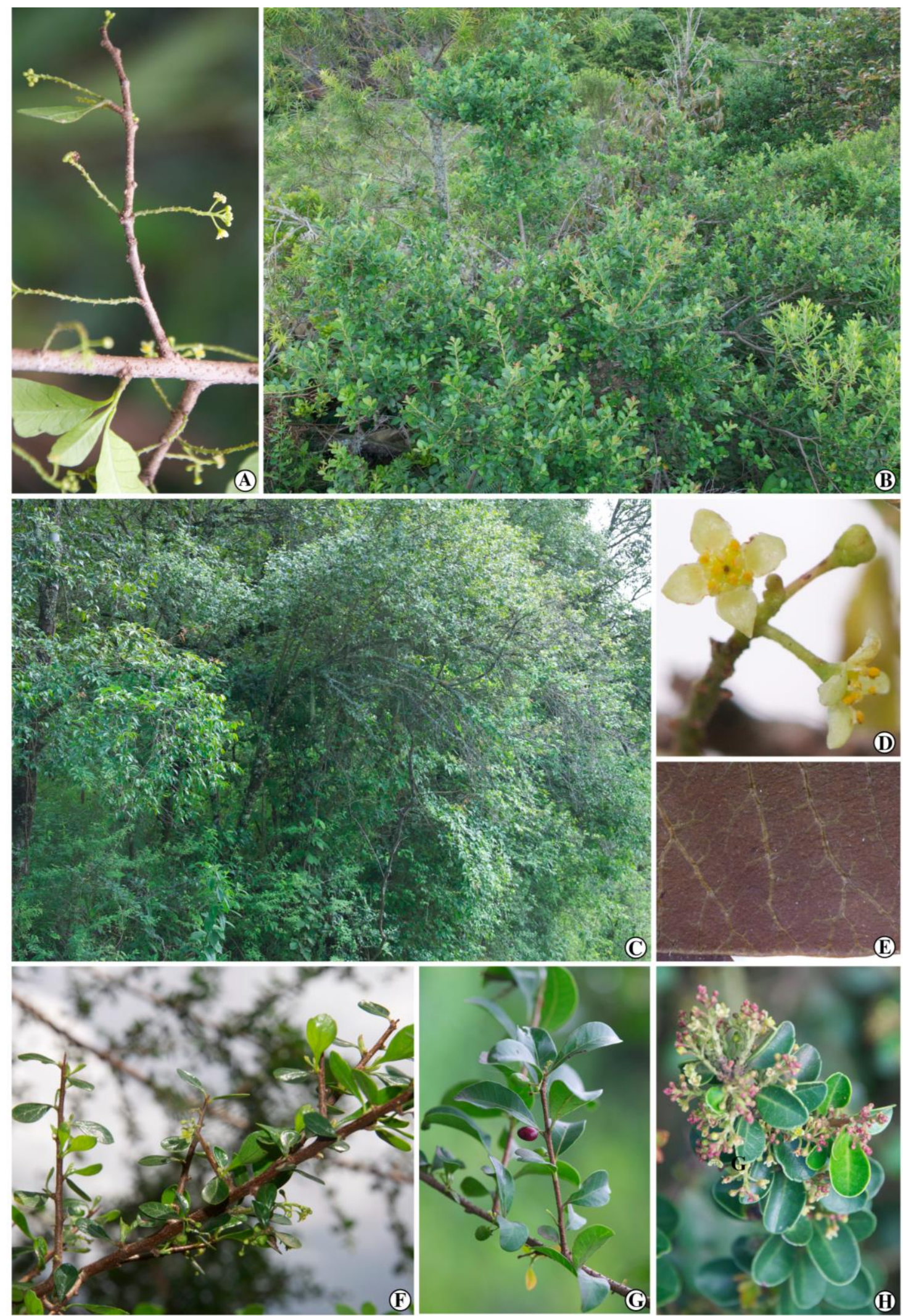

Fig. 10. Taxa of Schinus sect. Myrtifolia: A. Flowering branchlets with staminate inflorescences of Schinus myrtifolia. B. Habit of Schinus sp. nov. 3. C. Habit of Schinus myrtifolia. D. Staminate flowers of Schinus sp. nov. 3. E. Leaf of Schinus meyeri with detail of cladodromous secondary veins and tertiary veins. F. Flowering branchlets of Schinus microphylla. G. Fruiting branchlets of Schinus myrtifolia. H. Flowering branch with staminate inflorescences of Schinus sp. nov. 3. Pictures C.L. Silva-Luz. 
placed in S. subg. Duvaua sect. Pseudoduvaua except for S. microphylla I.M. Johnst., a species recognized by Barkley $(1944,1957)$ as belonging to $S$. subg. Duvaua sect. Duvaua. This section is formed by armed and unarmed shrubs or treelets, the leaves have secondary veins conspicuous cladodromous, inflorescences usually branched pseudoracemes or thyrsoids, rarely panicles, its flowers are tetramerous bearing petals longer than stamens, and the petals often have 1-3 cladodromous secondary veins. The fruiting branches are lax with pink fruits essentially laterally compressed (Fig. 10). The anatomical study of leaves demonstrates a dorsiventral mesophyll (Fig. $5 G)$, a vascular tissue of the petiole and midrib mostly composed by crescent-shaped bundles (Fig. 5B,D) and the petiole with homogeneous parenchyma (Fig. 5B). The morphological and taxonomic revision of $S$. sect. Myrtifolia is ongoing and have already pointed out a significant number of taxonomic circumscription problems because many specimens, especially those from Bolivia, have been identified as either $S$. andina or $S$. myrtifolia. However, a wide variation in character states is observed in specimens determined either as the former or the latter, and our detailed morphological study of numerous of exsiccatae indicates that specimens previously identified as $S$. andina or $S$. myrtifolia can be divided into more species. In this way, our taxonomic revision highlights all range of morphological variation within $S$. sect. Myrtifolia, which has been overlooked until now (Silva-Luz et al. in prep., see Chpater 2).

Taxa list. Schinus gracilipes I.M.Johnst., S. meyeri F.A. Barkley, S. microphylla I.M. Johnst., S. myrtifolia (Griseb.) Cabrera e S. venturii F.A. Barkley.

Schinus sect. Pilifera Silva-Luz \& J.D. Mitch., sect. nov. - Type: Schinus pilifera I.M. Johnst.

Schinus subg. Duvaua (Kunth) F.A. Barkley pro parte, Brittonia 5(2): 165. 1944, syn. nov. Duvaua Kunth, Ann. Sci. Nat. (Paris) 2: 340. 1824. Schinus subg. Duvaua sect. Duvaua F.A. Barkley pro parte, Brittonia 5(2): 165. 1944, syn. nov. Type: Schinus polygama (Cav.) Cabrera (Amyris polygama Cav.).

Diagnosis. Differs from S. sect. Schinus, S. sect. Terebinthifolia and S. sect. Lentiscifolia because of its simple or dissected leaves (vs. pinnately compound leaves). Differs from $S$. sect. Montana by its flowers with petals shorter than stamens. It is distinct from $S$. sect. Myrtifolia because of its globose fruits (vs. fruits laterally compressed). Differs from $S$. sect. Duvaua by its plants bearing pentamerous flowers and leaves with marginal secondary vein inconspicuous (vs. plants bearing pentamerous or tetramerous flowers, and leaves with marginal secondary vein 
conspicuous). Differs from $S$. sect. Atlantica because of its ascending branches, mostly borne at angles between 90 and 45 degrees to the branches from which they arise, and leaves with different shape and size in adult and young individuals (vs. elongate and pendulous branches, and leaves with similar shape and size in adult and young individuals).

Schinus sect. Pilifera comprises approximately nine species, which were recognized as part of $S$. subg. Duvaua sect. Duvaua (Barkley, 1944, 1957; Cabrera, 1938). Species of this section can be found in a broad range of arid vegetation types, where they are commonly found in Angentinean areas of deciduous xerophytic forests and scrublands in Monte and Espinal provinces, also extending into Uruguay. In Paraguay, Bolivia and Argentina can be also found in areas of Chaco, occurring in thorn forests and Quebracho woodland, and in Bolivian and Argentinean Andean dry forests. Schinus pearcei Engl. occurs at high elevation, in pre-Puna and Puna areas of Bolivia and Peru, and scattered populations are also found in Chile. Species of this section are characterized by thorny branches bearing simple leaves, except for $S$. pearcei, a rare species, which has unarmed branches and dissected leaves. Leaves have secondary vein cladodromous, craspedodromous or brochidodromous. The inflorescences are pseudoracemes, thyrsoids or panicles, the flowers are pentamerous with petals shorter than stamens, the fruits are globose and pink or purple (Fig. 11). The anatomical study of leaves demonstrates an isobilateral mesophyll (Fig. 5F), a vascular tissue of the petiole and midrib composed by crescent-shaped bundles (Fig. 5B,D) and the petiole with homogeneous parenchyma (Fig. 5B). Young individuals of species in this section often bear leaves distinct in shape and size from leaves of the adult individuals. In fact, this can contribute to the misleading recognition of new taxa, such as $S$. fasciculata var. arenicola (Hauman) F.A. Barkley (Steibel and Troiani, 2008). Our phylogenetic study strongly supports the recognition of $S$. sect. Pilifera (Fig. 2), although the relationship among the species is still unclear. Further investigations should considerate using a phylogenomic approach, since our reconstructions of the Schinus phylogeny indicate a low level of genetic divergence among individuals of recent co-ancestry. Also, phylogeographical studies seem to be promising to a better understanding of macro and microevolutionary processes involved in the arid vegetation types from Southern South American biota. Moreover, a new taxonomic revision would contribute in identifying possible morphological traits that can be useful in species delimitation, in particular for the $S$. pilifera complex. Our phylogenetic study also provides evidences about existence of cryptic species (Schinus sp. nov. 1 - Fig. 2), which are corroborated by preliminary morphological study. Thus, a 

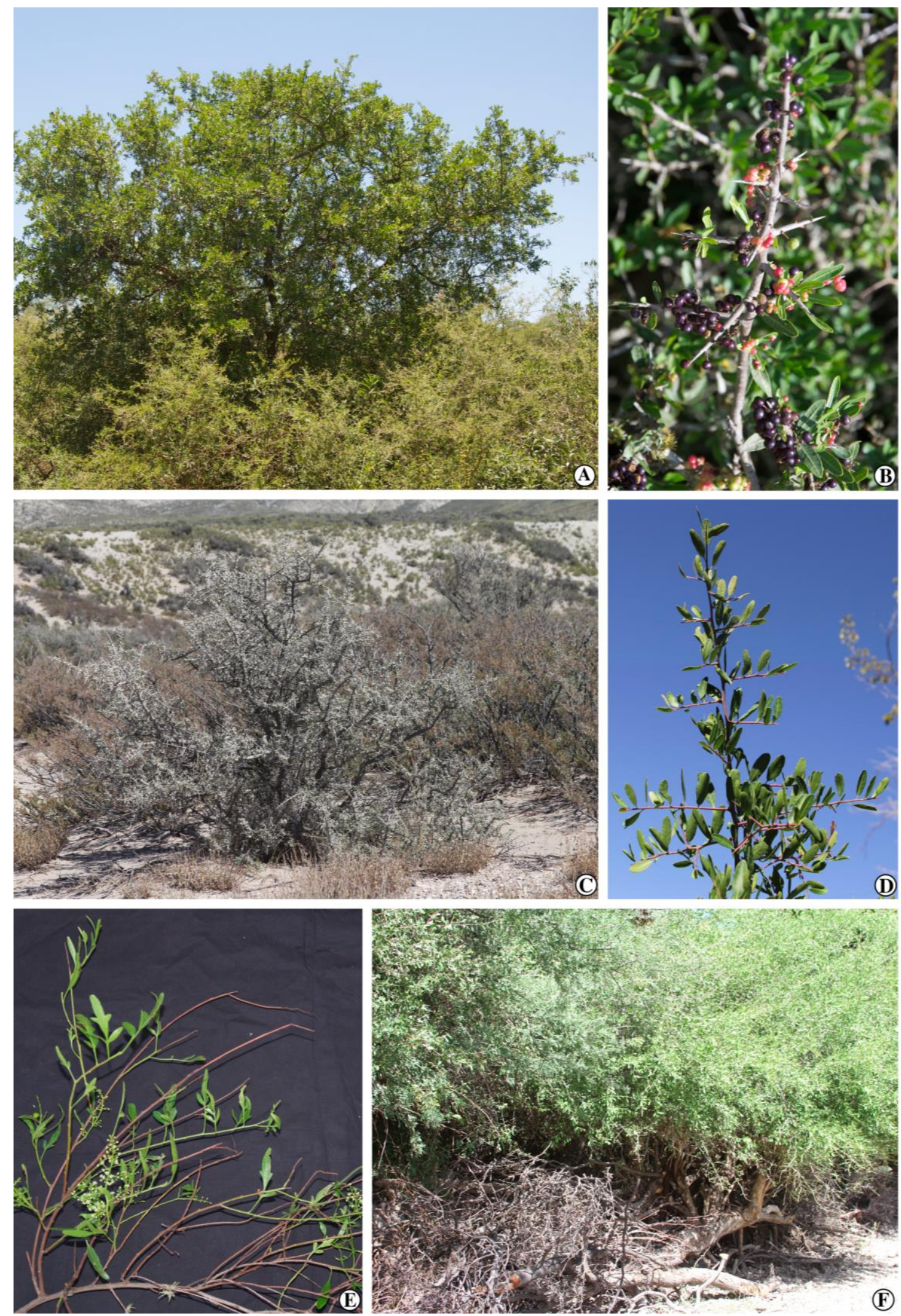

Fig. 11. Taxa of Schinus sect. Pilifera: A. Habitat of Schinus pilifera. B. Fruiting branchlets of Schinus uruguayensis. C. Habitat of Schinus johnstonii. D. Sterile branchlets of Schinus bumelioides. E. Flowering branchlets of Schinus pearcei. F. Habit of Schinus bumelioides. Pictures C.L. Silva-Luz. 
taxonomic revision will be relevant to identify consistent morphological traits, provide description for new species and reevaluate the species limits in S. pilifera complex.

Taxa list. Schinus bumelioides I.M. Johnst., S. fasciculata (Griseb.) I.M. Johnst., S. johnstonii F.A. Barkely, S. pearcei Engl., S. pilifera I.M. Johnst., S. praecox (Griseb.) Speg. and S. sinuata (Griseb.) Engl.

New combination. Schinus uruguayensis (F.A. Barkley) Silva-Luz, comb. nov. Schinus engleri var. uruguayensis F.A. Barkley, Lilloa 28: 49. 1957. Type: Uruguay, Juan Jackson, 15 Nov 1940, Gallinal, Aragone, Bergalli, Campal \& Rosengurtt PE-4321-1/2 (Holotype: LIL!; isotype: LP!).

Schinus sect. Schinus Marchand emend. Silva-Luz, Rev. Anacardiac. 163. 1869. Schinus subg. Schinus F.A. Barkley, pro parte, Brittonia 5(2): 184. 1944, syn. nov. Type: Schinus molle L.

Diagnosis. Differs from S. sect. Atlantica, S. sect. Duvaua, S. sect. Montana, S. sect. Myrtifolia, S. sect. Pilifera because of its pinnately compound leaves (vs. simple or dissected leaves). Differs from $S$. sect. Lentiscifolia by its imparippinate leaves (vs. paripinnate leaves), and from $S$. sect. Terebinthifolia because of its lanceolate or linear leaflets (vs. obovate, ovate, oblong or elliptic leaflets).

Schinus sect. Schinus comprises S. areira L. and S. molle L., both species placed in S. sect. Schinus (Marchand, 1869; Engler, 1876) or S. subg. Schinus (Barkley, 1944, 1957; Cabrera, 1938) together with other compound leaves species. The status of $S$. areira as species or variety has been subject of discussion. Candolle (1825), Marchand (1869), Engler (1876), Cabrera (1938), Barkley (1944, 1957) and Pennington and Reynel (2004) recognized S. areira as variety under S. molle, whereas Martínez-Crovetto (1963), Pereyra (1996), Muñoz (1990, 2000), and Varela and Novara (2007) recognized as a distinct species. Our phylogenetic study (Fig. 2) using a broad sampling (i.e., specimens of $S$. molle var. molle, S. molle var. areira (L.) DC., and S. molle var. rusbyi F.A.Barkley) demonstrates two strongly supported internal clades (clade 2), one with samples of the two latter varieties, and the other comprising samples of the typical variety. These results agree with morphological studies of Martínez-Crovetto (1963) and Pereyra (1996) in demonstrating that both species can be differentiated mostly on account of several leaf traits. Also, each of them is geographically and ecologically structured. For instance, $S$. areira occurs in Bolivian, Peruvian and Argentinean Andean dry forests, pre-Puna and Puna, and since it is planted as an ornamental, it was introduced in Central America and Mexico (Barfod, 1987), and also in Chile by the Incas (Hoffmann, 1983). Schinus molle 
occurs in the Atlantic Forests from south Brazil, northeast Argentina, northeast and south of Paraguay, and Uruguay. Both species can be considered as invasive and naturalized and are widespread in Old and New World where they have been introduced as ornamentals (Barkley, 1957; Nel, 2004). Taking all the evidences before mentioned we recognize $S$. areira as a distinct species from $S$. molle.

Schinus sect. Schinus comprises species with unarmed branches, rachis narrowly winged and imparipinnate leaves. The inflorescences are panicles bearing pentamerous flowers with petals longer or as long as stamens. The fruiting branches are often congested with red and globose fruits (Fig. 12A-B,D). The anatomical study of leaves demonstrates an isobilateral mesophyll (Fig. 5F), a vascular tissue of the petiole and midrib composed by crescent-shaped and dorsal bundles (Fig. 5A,E) and the petile with spongy parenchyma on abaxial side and Palisade parenchyma on adaxial side (Fig. 5A).

Schinus sect. Terebinthifolia Silva-Luz \& J.D. Mitch., sect. nov. - Type: Schinus terebinthifolia Raddi.

Schinus subg. Schinus F.A. Barkley pro parte, Brittonia 5(2): 184. 1944, syn. nov.

Diagnosis. Differs from S. sect. Atlantica, S. sect. Duvaua, S. sect. Montana, S. sect. Myrtifolia and $S$. sect. Pilifera because of its compound leaves (vs. simple or dissected leaves). Differs from $S$. sect. Lentiscifolia by its imparipinnate and green leaves (vs. paripinnate and grayish-green leaves). Differs from $S$. sect. Schinus because of its obovate, ovate, oblong or elliptic leaflets (vs. lanceolate or linear leaflets).

Schinus sect. Terebinthifolia comprises three species which were recognized as part of S. sect. Schinus (Marchand, 1869) or S. subg. Schinus (Barkley, 1944, 1957; Cabrera, 1938). Its species are distributed in the forests and related formations of the Atlantic Forest domain, and also in disturbed areas in Brazil, northeastern Argentina, Paraguay and Uruguay. Schinus terebinthifolia Raddi shows the broadest distribution in the genus, a species which is cultivated as ornamental in subtropical and tropical areas of both hemispheres. It has escaped cultivation and become one of the most pernicious plant in Florida, Bermuda, Bahamas, Hawaii and Australia (Ewel et al., 1982; Mitchell, 1997; Schmitz et al., 1997). Species of this section are characterized by unarmed trees, treelets and shrubs, and S. weinmannifolia (Fig. $12 \mathrm{C}, \mathrm{E})$ is a rhizomatous shrubs, an unusual habitat in the genus and elsewhere in the family. Leaves are imparipinnate compound leaves with secondary vein 

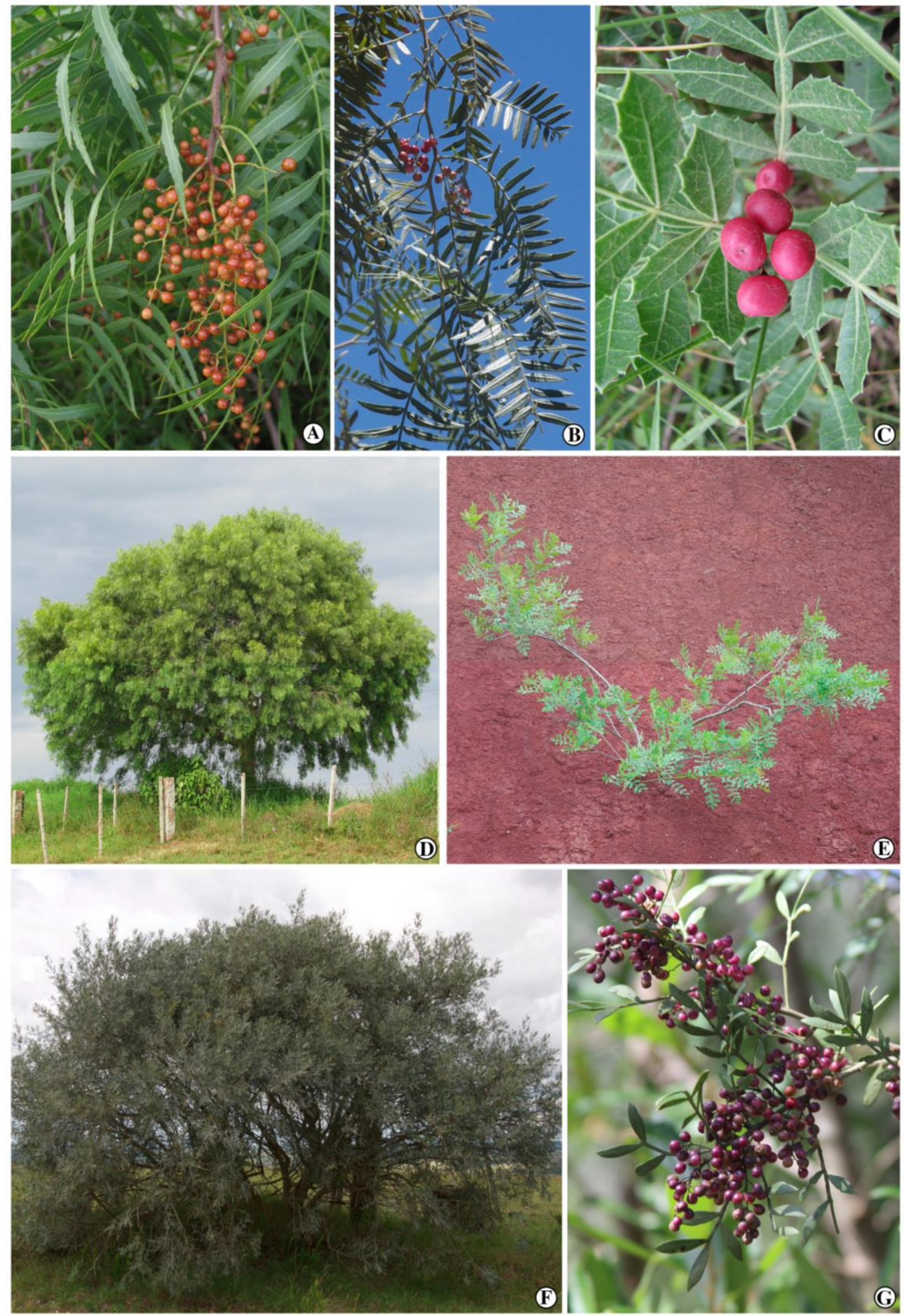

Fig. 12. Compound-leaved taxa. A. Fruiting branches of Schinus molle (S. sect. Schinus). B. Fruiting branches of Schinus areira (S. sect. Schinus). C. Fruiting branchlets of Schinus weinmanniifolia (S. sect. Terebinthifolia). D. Habitat of Schinus molle. E. Habitat of Schinus weinmanniifolia. F. Habitat of Schinus lentiscifolia (S. sect. lentiscifolia). G. Fruiting branchlets of Schinus lentiscifolia. Pictures A-C and E-G, C.L. Silva-Luz; D, G. Heiden. 
cladodromous or craspedodromous. The inflorescences are panicles with pentamerous flowers, the petals are as long as the stamens, and the fruits are red and globose (Fig. 12C). The anatomical study of leaves demonstrates an isobilateral mesophyll (Fig. 5F), a vascular tissue of the petiole and midrib composed by crescent-shaped and dorsal bundles (fig. 5A,E) and the petiole with spongy parenchyma (Fig. 5C). Our phylogenetic study (Fig. 2) using a broad sampling (i.e., specimens of $S$. terebinthifolia var. terebinthifolia, $S$. terebinthifolia var. acutifolia Engl., S. terebinthifolia var. pohliana Engl., S. terebinthifolia var. raddiana Engl. and S. terebinthifolia var. rhoifolia (Mart.) Engl.) demonstrated three well supported internal clades (clade 1). One clade with specimens of $S$. terebinthifolia var. rhoifolia, another clade with the remaining varieties of $S$. terebinthifolia, and the last clade with specimens of $S$. weinmanniifolia. Specimens of $S$. terebinthifolia var. rhoifolia are not nested together with the remainging varieties, and instead are positioned as sister to S. weinmanniifolia. Noteworthy, Martius (1837) described S. rhoifolia Mart., which was later recognized by Engler (1876) as a variety under S. terebinthifolia. This taxon is characteristic of sandy vegetation known as restinga occurring along the Brazilian coastal plains, where it can be easily recognized because of its larger and less numerous leaflets. Based on the phylogenetic and ecogeographical evidences, we here propose the recognition of $S$. rhoifolia at species level. A new morphological study will be relevant in reevaluating the varieties proposed by Engler (1876), and might provide additional morphological traits and contribute to improvement of species delimitation.

Taxa list. Schinus rhoifolia Mart., S. terebinthifolia Raddi var. terebinthifolia, $S$. terebinthifolia var. acutifolia Engl., S. terebinthifolia var. pohliana Engl., $S$. terebitnhifolia var. raddiana Engl., S. weinmanniifolia Mart. ex Engl.

\section{Conclusions}

This study represent a relevant step toward the knowledge about the Anacardiaceae taxa from southern South America, since Schinus is the most diversified genus in terms of number of species and habitat range. Here we scrutinize for the first time the phylogenetic relationships within Schinus, using samples of 47 taxa including nearly all varieties as well as a large number of molecular markers, most of them recently developed for Commiphora (Burseraceae). Our analyses strongly supported the monophyly of Schinus, but also indicate that its infrageneric groups S. subg. Duvaua sect. Duvaua and S. subg. Duvaua sect. Pseudoduvaua are polyphyletic and have been defined using homoplastic characters. We propose a novel infrageneric classification recognizing eight monophyletic sections which are 
strongly correlated to particular geographic and ecological areas. This study evidenced relationship among Schinus species that had never been demonstrated before and will likely provide a stable taxonomy, since the sections here defined are well characterized morphologically. Ancestral state reconstructions suggested that some morphological and leaf anatomy characters are valuable in characterizing and also as potential synapomorphies for large lineages, however most of the traits are homoplastic in diagnosing the main clades. The thorny branch, a feature traditionally used in Schinus circumscription was demonstrated to be a homoplastic character that appeared independently at least five times within the simple-leaved lineage. Our study also suggests that thorny branches, as well as branches arranged as a cage, may be correlated to plant defense against mammalian herbivores. The phylogeny of Schinus also provide a framework for reproductive studies, particularly those associated with pollinator syndromes, since the petal to stamen size ratio character seems to be mostly correlated to distinct geographical areas. The eight clades recovered in the phylogenetic analyses are mostly allopatric or ecologically distinct, suggesting that vicariance may have played a major role in the biogeographical history and diversification of its species. Therefore, a study investigating biogeographical patterns associated to the diversification of Anacardiaceae taxa seems to be particular promising and may also contribute to the understanding of southern South American biota. This study is the first phase of a long-term effort to produce a taxonomic review for all species of Schinus. For instance, a taxonomic revision of $S$. sect. Myrtifolia is underway and results already pointed out to several problems of species delimitation and new taxa (see Chapter 2). Even though the adittion of novel molecular markers have substantially incremented the phylogeny of Schinus and revealed that most main lineages are strongly supported, the relationship among closely related species remains unclear, especially within $S$. sect. Pilifera and S. sect. Atlantica. Further investigations should considerate using a phylogenomic approach, since our reconstruction of the Schinus phylogeny indicates a low level of genetic divergence among individuals of recent co-ancestry.

\section{References}

Alexander, P.J., Govindarajalu, R., Bacon, C.D., Bailey, C.D., 2007. Recovery of plant DNA using a reciprocating saw and silica- based columns. Molecular Ecology Notes 7(1): 5-9.

Al-Saghir, M.G. 2010., Phylogenetic analysis of the genus Pistacia L. (Anacardiaceae) based on morphological data. Asian Journal of Plant Sciences 9 (1): 28-35. 
Archibald, S. \& Bond, W.J., 2003. Growing tall vs growing wide: tree architecture and allometry of Acacia karroo in forest, savanna, and arid environments. Oikos 102: 3-14.

Ashman, T.L., Morgan, M.T., 2004. Explaining phenotypic selection on plant attractive characters: male function, gender balance or ecological context? Proc $R$ Soc $B$ 271:553-559.

Bachelier, J.B., Endress, P.K., 2009. Comparative floral morphology and anatomy of Anacardiaceae and Burseraceae (Sapindales), with a special focus on gynoecium structure and evolution. Botanical Journal of the Linnean Society 159: 499-571.

Barfod, A., 1987, 104. Anacardiaceae, In G. Harling and L. Andersson (eds). Flora of Ecuador 3, $50 \mathrm{pp}$.

Barkley, F.A., 1944. Schinus L. Brittonia 5(2): 160-198.

Barkley, F.A., 1957. A study of Schinus L. Lilloa 28: 5-110.

Barret, S.C.H., Harder, L.D., 1996. Ecology and evolution of plant mating. Trends Ecol Evol 11: 73-79.

Bond, W.J., Lee, W.G., Craine, J.M., 2004. Plant structural defences against browsing birds: a legacy of New Zealand's extinct moas. Oikos 104: 500-508.

Burckhardt, D., Basset, Y. 2000. The jumping plant-lice (Hemiptera, Psylloidea) associated with Schinus (Anacardiaceae): systematics, biogeography and host plant relationships. Journal of Natural History 34: 57-155.

Burckhardt, D., Queiroz, D.L., 2017. The jumping plant-lice of the Neotropical genus Tainarys (Hemiptera: Psylloidea) associated with Anacardiaceae. Zootaxa 4232(4): 535-567.

Cabrera, A.L., 1938. Revisión de las Anacardiáceas Austroamericanas. Rev. Mus. La Plata, Bot. 2: 3-64.

Cabrera, A.L., A. Willink., 1973. Biogeografía de América Latina. Monografía 13, Serie de Biología, OEA, Washington, D.C. 122p.

Carmello-Guerreiro, S.M., 1996. Morfologia, anatomia e desenvolvimento de frutos, sementes e plântulas de Schinus terebinthifolius Raddi, Lithraea molleoides (Vell.) Engl., Myracrodruon urundeuva Fr. Allem. e Astronium graveolens Jacq. Tese de Doutorado, Universidade Estadual Paulista, Rio Claro, SP, Brasil. 90 p.

Carmello-Guerreiro, S.M., Sartori Paoli, A.A., 1999. Morfologia e anatomia da semente de Schinus terebinthifolius Raddi (Anacardiaceae) em desenvolvimento. Brazilian Journal of Botany 22(1): 91-98.

Carmello-Guerreiro, S.M., Sartori Paoli, A.A., 2002. Ontogeny and Structure of the Pericarp of Schinus terebinthifolius Raddi (Anacardiaceae). Brazilian Archives of Biology and Technology 45(1): 73-79. 
Carmello-Guerreiro, S.M., Sartori Paoli, A.A., 2005. Anatomy of the pericarp and seed-coat of Lithraea molleoides (Vell.) Engl. (Anacardiaceae) with taxonomic notes. Brazilian Archives of Biology and Technology 48: 599-610.

Castresana, J., 2000. Selection of conserved blocks from multiple alignments for their use in phylogenetic analysis. Mol. Biol. Evol. 17: 540-552.

Catalán, P., Kellogg, E.A., Olmstead, R.G., 1997. Phylogeny of Poaceae subfamily Pooideae based on chloroplast ndhF gene sequences. Molecular Phylogenetics and Evolution 8(2): 150-166.

Cesário, L.F., Gaglianone, M.C., 2013. Polinizadores de Schinus terebinthifolius Raddi (Anacardiaceae) em formações vegetacionais de restinga no norte do estado do Rio de Janeiro. Biosc. J. 29(2): 828-833.

Charles-Dominique, T., Davies, T.J., Hempson, G.P., Bezeng, B.S., Daru, B.H., Kabongo, R.M., Maurin, O., Muasya, A.M., Bank, M., Bond, W.J., 2016. Spiny plants, mammal browsers, and the origin of African savannas. Proceedings of the National Academy of Sciences USA 113(38): E5572-E5579.

Charles-Dominique, T., Barczi, J-F., Roux, E.L., Chamaillé-Jammes, S., 2017. The architectural design of trees protects them against large herbivores. Funtional Ecology 1365-2435.12876.

Collins, E.S., Gostel, M.R., Weeks, A., 2016. An expanded nuclear phylogenomic PCR toolkit for Sapindales. Applications in Plant Sciences 4(12): 1600078.

Copeland, H.F., 1959. The reproductive structures of Schinus molle (Anacardiaceae). Madroño 15: 14-25.

Darriba, D., Taboada, G.L. Doallo, R., Posada, D., 2012. jModelTest 2: more models, new heuristics and parallel computing. Nature Methods 9(8): 772.

De Candolle, A.P., 1825. Prodomus Systematis Naturalis Tegni Vegetabilis. Paris, vols. 1-2.

Dias, G.G., Ferreira, B.G., Moreira, G.R.P., Isaias, R.M.S., 2013a. Developmental pathway from leaves to galls induced by a sap-feeding insect on Schinus polygamus (Cav.) Cabrera (Anacardiaceae). Annals of the Brazilian Academy of Sciences 85(1): 187-200.

Dias, G.G., Moreira, G.R.P., Ferreira, B.G., Isaias, R.M.S. 2013b. Why do the galls induced by Calophya duvauae Scott on Schinus polygamus (Cav.) Cabrera (Anacardiaceae) change colors? Biochemical Systematics and Ecology 48: 111122.

Drummond, A.J., Suchard, M.A., Xie, D., Rambaut, A., 2012. Bayesian phylogenetics with BEAUti and the BEAST 1.7. Mol. Biol. Evol. 29 (8): 1969-1973. 
Duchene, S., Molak, M., Ho, S.Y.W., 2014. ClockstaR: choosing the number of relaxed-clock models in molecular phylogenetic analysis. Bioinformatics 30 (7): 1017-1019.

Eckert, G., 1966. Entwicklungsgeschichtliche und blütenanatomische Untersuchungen zum Problem der Obdiplostemonie. Botanische Jahrbücher für Systematik 85: 523-604.

Engler, H.G.A., 1876. Anacardiaceae. In C.F.P. Martius and A.G. Eichler (eds.) Flora brasiliensis. Fleischer, Leipiz, vol. 12, pars 2, p. 367-418.

Engler, H.G.A., 1881. Botanische Jahrbücher für Systematik, Pflanzengeschichte und Pflanzengeographie, v. 1, p. 423.

Ewel, J.J., 1986. Invasibility: Lessons from South Florida. In H. A. Moony and J. A. Drake (eds) Ecology of biological invasions of North Samerica and Hawaii, Ecological Studies 58: 214-230.

Felsenstein, J., 1985. Confidence-limits on phylogenies - an approach using the bootstrap. Evolution 39: 753-779.

Gerlach, D., 1984. Botanische Mikrotechnik: eine Einführung. 3rd ed., Stuttgart, Georg Thieme.

Gernhard, T., 2008. The conditioned reconstructed process. J. Theor. Biol. 253 (4): 769-778.

Gerrits, P.O., 1991. The application of glycol methacrylate in histotechnology; some fundamental principles. Department of Anatomy and Embryology, State University Groningen, Groningen. 80p.

Geeta, R., Dávalos, L.M., Levy, A., Bohs, L., Lavin, M., Mummenhoff, K., Sinha, N., Wojciechowski, M.F., 2011. Keeping it simple: flowering plants tend to retain, and revert to, simple leaves. New Phytologist 193(2): 481-493.

Göldel, B., Araujo, A.C., Kissling, W.D., Svenning, J-C., 2016. Impacts of large herbivores on spinescence and abundance of palms in the Pantanal, Brazil. Botanical Journal of the Linnean Society 182(2): 465-479.

Gostel, M.R., Coy, K.A., Weeks, A., 2015. Microfluidic PCR-based target enrichment: A case study in two rapid radiations of Commiphora (Burseraceae) from Madagascar. Journal of Systematics and Evolution 53(5): 411-431.

Gowda, J., Raffaele, E., 2004. Spine production is induced by fire: a natural experiment with three Berberis species. Acta Oecologica 26: 239-245.

Gut, B., 1966. Beiträge zur morphologie des Gynoeceums und der Blütenachse einiger Rutaceen. Botanische Jahrbücher für Systematik 85: 151-247.

Harms, H., 1940. Meliaceae. In: Engler A, Prantl K, (eds) Die natürlichen Pflanzenfamilien, 2nd edn, 19bl. Leipzig: Engelmann, 1-172. 
Hinojosa, L.F., Pérez, F., Gaxiola, A., Sandoval, I. 2010. Historical and phylogenetic constraints on the incidence of entire leaf margins: insights from a new South American model. Global Ecol Biogeogr. 20(3): 380-390.

Hoffmann, A.E., 1989. Flora silvestre de Chile, zona central. Ediciones Fundación Claudio Gay, 2nd edn (Santiago), 255 pp.

Hershkovitz, M.A., Arroyo, M.T.K., Bell, C., Hinojosa, L.F., 2006. Phylogeny of Chaetanthera (Asteraceae: Mutisieae) reveals both ancient and recent origins of the high elevation lineages. Mol. Phylogenet. Evol. 41: 594-605.

Huelsenbeck, J.P., Ronquist, F., 2001. MRBAYES: Bayesian inference of phylogenetic trees. Bioinformatics 17: 754-755.

Johansen, D.A., 1940. Plant microtechnique. New York, McGraw-Hill.

Lanfear, R., Calcott, B., Ho, S.Y.W, Guindon, S., 2012. PartitionFinder: combined selection of partitioning schemes and substitution models for phylogenetic analyses. Molecular Biology and Evolution 29(6): 1695-1701.

Lázaro, A., Hegland, S.J., Totland, Ø., 2008. The relationships between floral traits and specificity of pollination systems in three Scandinavian plant communities. Oecologia 157(2): 249-257.

Lenzi, M., Orth, A.I., 2004. Caracterização funcional do sistema reprodutivo da aroeira-vermelha (Schinus terebinthifoliusRaddi), em Florianópolis-SC. Brasil. Rev. Bras. Frutic. 26(2): 198-201.

Little, S.A., Kembel, S.W., Wilf, P., 2010. Paleotemperature Proxies from Leaf Fossils Reinterpreted in Light of Evolutionary History. PLoS ONE 5(12): e15161.

Lomolino, M.V., Riddle, B.R., Brown, J.H. 2006. Biogeography. Ed. 3. Sinauer Associates, Sunderland.

Maddison, W.P., Maddison, D.R. 2014. Mesquite: a modular system for evolutionary analysis. Version 3.02 <http://mesquiteproject.org>.

Marchand, N.L., 1869. Révision du groupe des Anacardiacées. Balliere, Sons, Paris.

Martínez-Crovetto, R., 1963. Estudio taxonômico-biométrico de Schinus molle y Schinus areira, Anacardiaceae. Bonplandia 1(3): 225-244.

Martius, K.F.P., 1837. Herbarium Florae Brasiliensis. Flora 20: (Beibläter) 1-128.

McNeill, J., Barrie, F.R., Buck, W.R., Demoulin, V., Greuter, W., Hawksworth, D.L., Herendeen, P.S., Knapp, S., Marhold, K., Prado, J., 2012. Prud'homme van Reine, W.F., Smith, G.F., Wiersema, J.H. \& Turland, N.J. (Eds.) (2012) International Code of Nomenclature for algae, fungi, and plants (Melbourne Code). Adopted by the Eighteenth International Botanical Congress Melbourne, Australia, July 2011. Koeltz Scientific Books, Königstein, XXX + 208 pp. [Regnum Vegetabile 154]. 
2011. Koeltz Scientific Books, Königstein, XXX +208 pp. [Regnum Vegetabile 154].

Miller, M.A., Pfeiffer, W., Schwartz, T., 2010. "Creating the CIPRES Science Gateway for inference of large phylogenetic trees" in Proceedings of the Gateway Computing Environments Workshop (GCE), 14 Nov. 2010, New Orleans, LA pp 1 8.

Miller, A., Young, D.A., Wen, J., 2001. Phylogeny and Biogeography of Rhus (Anacardiaceae) based on ITS sequence data. International Journal of Plant Sciences 162(6): 1401-1407.

Mitchell, J.D. 1997. Anacardiaceae. In A.R.A. Gorts-Van Rijs and M.J. Jansen-Jacobs (eds.) Flora of the Guianas - Serie A: Phanerogams 19(129): 1-79.

Mogni, V.Y., Kahan, M.A., Queiroz, L.P., Vesprini, J.L., Ortiz, J.P., Prado, D.E., 2016. Optimization of DNA extraction and PCR protocols for phylogenetic analysis in Schinopsis spp. and related Anacardiaceae. SpringerPlus 5: 477.

Moreira, G.R.P., Gonçalves, G.L., Eltz, R.P., Blas, G.S., Davis, D.R., 2012. Revalidation of Oliera Brèthes (Lepidoptera: Cecidosidae) based on a redescription of $O$. argentinana and DNA analysis of Neotropical cecidosids. Zootaxa 3557: 1-19.

Muñoz, J.D., 1990. Anacardiaceae. In R. Spichiger and L. Ramella (eds.) Flora del Paraguay 14: 7-84. Missouri Botanical Garden \& Conservatoire et Jardin Botaniques de la Ville de Geneve.

Muñoz, J.D., 2000. Anacardiaceae. In A.T. Hunziker (ed.) Flora Fanerogámica Argentina 65:1-28.

Nel, J.L., Richardson, D.M., Rouget, M., Mgidi, T.N., Mdzeke, N., Le Maitre, D.C., Wilgen, B.W., Schonegevel, L., Henderson, L., Neser, S., 2004. A proposed classification of invasive alien plant species in South Africa: towards prioritizing species and areas for management action. South Africa Journal of Science 100: 53-64.

Nelson, G.J. 1972. Phylogenetic relationships and classification. Systematic Zoology 21: 227-230.

Nie, Z., Sun, H., Meng, Y., Wen, J., 2009. Phylogenetic analysis of Toxicodendron (Anacardiaceae) and its biogeographic implications on the evolution of north temperate and tropical intercontinental disjunctions. Journal of Systematics and Evolution 47(5): 416-430.

Nuñez, C., Sàiz, F., 1994. Cecidios en vegetación autóctona de Chile de clima mediterráneo. Anales del Museo de Historia Natural de Valparaíso 22: 57-80. 
O'Brien, T.P., Feder, N., McCully, M.E., 1964. Polychromatic staining of plant cell walls by toluidine blue O. Protoplasma 59: 368-373.

Ollerton, J., Alarcón, R., Waser, N.M., Price, M.V., Watts, S., Cranmer, L., Hingston, A., Peter, C.I., Rotenberry, J. 2009. A global test of the pollination syndrome hypothesis. Annals of Botany 103(9): 1471-1480.

Olson, D.M., Dinerstein, E., Wikramanayake, E.D., Burgess, N.D., Powell, G.V.N., Underwood, E.C., D’Amico, J.A., Itoua, I., Strand, H.E., Morrison, J.C., Loucks, C.J., Allnutt, T.F., Ricketts, T.H., Kura, Y., Lamoreux, J.F., Wettengel, W.W., Hedao, P. \& Kassem, K.R. 2001. Terrestrial ecoregions of the world: a new map of life on Earth. BioScience 51: 933-938.

Oxelman, B., Lidén, M., Berglund, D., 1997. Chloroplast rps 16 intron phylogeny of the tribe Sileneae (Caryophyllaceae). Plant Systematics and Evolution 206: 393-410.

Pell, S.K., Mitchell, J.D., Miller, A.J., Lobova, T.A., 2011. Anacardiaceae. In K. Kubitzki (ed.) The families and genera of vascular plants. X. Flowering plants. Eudicots. Sapindales, Curcubitales, Myrtales. Springer, Berlin, p. 7-50.

Pell, S.K., Mitchell, J.D., Lowry, P.P., Randrianasolo, A.,Urbatsch, L.E., 2008. Phylogenetic split of Malagasy and African taxa of Protorhus and Rhus (Anacardiaceae) based on cpDNAtrnL-trnFand nrDNA ETS and ITS sequence data. Systematic Botany 33: 375-383.

Pennington, R.T., Lavin, M., Prado, D.E., Pendry, C.A., Pell, S.K., Butterworth, C.A., 2004. Historical climate change and speciation: neotropical seasonally dry forest plants show patterns of both tertiary and quaternary diversification. Phylosophical Transactions of the Royal Society, Serie B 359: 515-537.

Pennington, T.D., Reynel, C., Daza, A., 2004. Illustrated guide to the trees of Peru. Sherbone: David Hunt, The Manse, Chapel Lane, Milborne Port

Pereyra, M.L.S., 1996. Diferenciación de estadios juveniles en Schinus molle L. y Schinus areira L. (Anacardiaceae). Aportes botânicos de Salta - Ser. Misceláneas 1(5): 1-9.

Peppe, D.J., Royer, D.L., Cariglino, B., Oliver, S.Y., Newman, S., Leight, E., Enikolopov, G., Fernandez-Burgos, M., Herrera, F., Adams, J.M., Correa, E., Currano, E.D., Erickson, J.M., Hinojosa, L.F., Hoganson, J.W., Iglesias, A., Jaramillo, C.A., Johnson, K.R., Jorgan, G.J., Kraft, N.J.B., Lovelock, E.C., Lusk, C.H., Niinemets, U., Peñuelas, J., Rapson, G., Wing, S.L., Wright, I.J., 2011. Sensitivity of leaf size and shape to climate: global patterns and paleoclimatic applications. New Phytologist 190: 724-739.

Rambaut, A., 2010. FigTree v1.3.1. Institute of Evolutionary Biology, University of Edinburgh. 
Rambaut, A., Drummond, A.J., 2007. Tracer v1.4. http://beast.bio.ed.ac.uk/Tracer.

Ronquist, F., Huelsenbeck, J.P., 2003. MrBayes 3: Bayesian phylogenetic inference under mixed model. Bioinformatics 19: 1572-1574.

Royer, D.L., Wilf, P., Janesko, D.A., Kowalski, E.A., Dilcher, D.L., 2005. Correlations of climate and plant ecology to leaf size and shape: potential proxies for the fossil record. American Journal of Botany 92: 1141-1151.

Schmitz, D.C., Simberloff, D., Hofstetter, R.H., Haller, W., Sutton, D. 1997. The ecological impact of nonindigenous species. In D. Simberloff, D.C., Schmitz, T.C., Brown (eds) Strangers in Paradise: Impact and Management of nonindigenous species in Florida. Island Press, Washington, D.C., p. 9-61.

Smith, F.H., Smith, E.C. 1942. Anatomy of the inferior ovary of Darbya. American Journal of Botany 29: 464- 471.

Somavilla, A., Sühs, R.B., Köhler, A., 2010. Entomofauna associated to the floration of Schinus terebinthifolius Raddi (Anacardiaceae) in the RioGrande do Sul State, Brazil. Biosc. J. 26(6): 956-965.

Stamatakis, A., 2014. RAxML version 8: a tool for phylogenetic analysis and postanalysis of large phylogenies. Bioinformatics 30(9): 1312-1313.

Stamatakis, A., Hoover, P., Rougemont, J., 2008. A rapid bootstrap algorithm for the raxml web servers. Syst. Biol. 57: 758-771.

Steibel, P.E., Troiani, H.O., 2008. La identidade de Schinus fasciculatus var. arenicola y rehabilitación de $S$. sinuatus (Anacardiaceae). Boletín de la Sociedad Argentina de Botánica 43(1-2): 157-166.

Sukumaran, J., Holder, M.T., 2010. DendroPy: a Python library for phylogenetic computing. Bioinformatics 26: 1569-1571.

Swofford, D.L., 2003. PAUP/: Phylogenetic Analysis Using Parsimony and Other Methods. Version 4.0b10. Sinauer, Sunderland, USA.

Taberlet, P., Gielly, L., Patou, G., Bouvet, J., 1991. Universal primers for amplification of three noncoding regions of chloroplast DNA. Plant Molecular Biology 17: 11051109.

Talavera, G., Castresana, J., 2007. Improvement of phylogenies after removing divergent and ambiguously aligned blocks from protein sequence alignments. Syst. Biol. 56: 564-577.

Totland, Ø., 2004. No evidence for a role of pollinator discrimination in causing selection on flower size through female reproduction. OIKOS 106: 558-564.

Varela, F.J., Novara, L.J., 2007. Anacardiaceae Lindl. Flora del Valle de Lerma. Aportes Botánicos de Salta, Ser. Flora 8(6): 1-28. 
Veblen, T.T., Kitzberger, T., Lara, A., 1992. Disturbance and forest dynamics along a transect from Andean rain forest to Patagonian shrubland. J. Veg. Sci. 3: 507-520. von Hagen, K. B., Kadereit, J.W. 2001. The phylogeny of Gentianella (Gentianaceae) and its colonization of the southern hemisphere as revealed by nuclear and chloroplast DNA sequence variation. Org. Divers. Evol. 1: 61-79.

Xie, L., Yang, Z.Y., Wen, J., Li, D.Z., Yi, T.S., 2014. Biogeographic history of Pistacia (Anacardiaceae), emphasizing the evolution of the Madrean-Tethyan and the eastern Asian-Tethyan disjunctions. Molecular Phylogenetics and Evolution 77: 136-146.

Yi, T., Miller, A.J., Wen, J., 2004. Phylogenetic and biogeographic diversification of Rhus (Anacardiaceae) in the Northern Hemisphere. Molecular Phylogenetics and Evolution 33 (3): 861-879.

Yi, T., Miller, A.J., Wen, J. 2007. Phylogeny of Rhus (Anacardiaceae) based on sequences of nuclear Nia-i3 intron and Chloroplast TrnC-TrnD. Systematic Botany 32(2): 379-391.

Yi, T., Wen, J., Golan-Goldhirsh, A., Parfitt, D.E., 2008. Phylogenetics and reticulate evolution in Pistacia ( Anacardiaceae). American Journal of Botany 95(2): 241-251.

Wannan, B.S., Quinn, C.J., 1990. Pericarp structure and generic affinities in the Anacardiaceae. Bot. J. Linn. Soc. 103: 225-252.

Weeks, A., Daly, D.C., Simpson, B.B., 2005. Phylogenetic relationships and historical biogeography of the Burseraceae based on nuclear and chloroplast sequence data. Molecular Phylogenetics and Evolution 35: 85-101.

Weeks, A., Zapata, F., Pell, S.K., Daly, D.C., Mitchell, J.D., Fine, P.V.A., 2014. To move or to evolve: Contrasting patterns of intercontinental connectivity and climatic niche evolution in "Terebinthaceae" (Anacardiaceae and Burseraceae). Frontiers in Genetics 5: 409.

Zhao, Z-G., Huang, S-Q., 2013. Differentiation of Floral Traits Associated with Pollinator Preference in a Generalist Pollinated Herb, Trollius ranunculoides (Ranunculaceae). International Journal of Plant Sciences 174(4): 637-646.

Zona, S., 2015. The correct gender of Schinus (Anacardiaceae). Phytotaxa 222 (1): 75-77.

Zwickl, D.J., 2006. Genetic algorithm approaches for the phylogenetic analysis of large biological sequence datasets under the maximum likelihood criterion. Ph.D. dissertation, The University of Texas at Austin. 
Hidden species in the Andean moist montane forests: a review of Schinus section Myrtifolia (Anacardiaceae)

\section{Abstract}

Schinus is a genus of approximately 42 species mainly distributed along a broad range of mostly arid vegetation types of southern South America. A phylogenetic study of the genus, based on molecular data, recently recovered eight well-supported lineages which are the basis for a novel sectional classification of the genus. Within the phylogenetic tree of Schinus, the simple-leaved species were grouped on a strongly supported clade, resolved into five internal clades. Schinus sect. Myrtifolia is a remarkable simple-leaved clade in which species reach the highest elevations within Anacardiaceae (up to 3,900 m altitude). The 11 species of this section are mostly endemic of Yungas and Tucumán-Bolivian forests, and two species also occur in pre-Puna, Puna and dry inter-Andean valleys from Argentina, Bolivia and Peru. A previous study of Schinus revealed that most of the morphological traits present a high level of homoplasy which makes challenger the diagnosis of the main clades, with exception of $S$. sect. Myrtifolia, since its species have tetramerous flowers and fruits laterally compressed, unusual character states that seem to be putative synapomorphies of this section. Starting a long-term effort to treat all species of the genus, we here focus on a taxonomic revision of $S$. sect. Myrtifolia, and review the taxonomic history, morphology and ecology of species comprising this section. Its members were previously placed in $S$. subg. Duvaua sect. Pseudoduvaua, except for $S$. microphylla, a species recognized as belonging to $S$. subg. Duvaua sect. Duvaua. Delimitation issues have been neglected in species of this section, since most studies have focused on taxa belonging to $S$. subg. Duvaua sect. Duvaua. The present morphological study reveals a significant number of taxonomic circumscription problems, especially between $S$. andina and S. myrtifolia. Detailed morphological analyses of numerous exsiccatae reveals four new species which are described herein. We provide identification key, descriptions, synonyms including three designations of lectotypes, two new combinations, illustrations, distribution maps, and comments on nomenclatural, distribution and preliminary conservation assessments of all species. The taxonomic novelties are here presented in Schinus sect. Myrtifolia as an attempt to disentangle its complexity and misidentified species taking into account the morphological traits of 
a virtually complete sampling and a careful nomenclatural revision. In this way we hope to highlight all range of morphological variation, especially within $S$. andina and $S$. myrtifolia, which has been overlooked until now.

Keywords Cloud forests; eudicots; rosids; Sapindales; taxonomic revision; Tropical Andes; Tucumán-Bolivian forests; Yungas

\section{Introduction}

In a reassessment of the Biodiversity hotspots, Myers et al. (2000) argued that the Tropical Andes region should be considered an extraordinarily important candidate for conservation support because it encompasses around 45,000 plant species in which 20,000 are endemic to the region. The Tropical Andes comprise a complex mosaic of high mountains and deep inter-Andean dry valleys (Swenson et al., 2012), where arid habitats are isolated by corridors of mesic habitats; conversely, the mesic habitats are isolated from each other by dry valleys and arid habitats that may provide conditions for micro-allopatric diversification (Mutke et al., 2014). It seems that this mountain-building and resulting isolation promoted diversification in South America (Antonelli et al., 2009; Luebert \& Weigend, 2014). Topography might play a crucial role in speciation since it could enhance opportunities for geographical isolation acting as an island-like formation (Hughes \& Eastwood, 2006). Moreover phylogenetic studies of representative Andean plant groups such as the perennial Castilleja (Tank \& Olmstead, 2009), Valerianaceae species (Bell \& Donoghue, 2005), Lupinus (Hughes \& Eastwood, 2006) and Alnus (Chen \& Li, 2004) have suggested that high elevations could provide a bridge for cold-tolerant North American plants into northern South America or vice versa (Hughes \& Eastwood, 2006; Pennington \& Dick, 2010). In the same way, temporal dynamics of landscape heterogeneity such as landslides has been considered as relevant to the generation and maintenance of biodiversity (Kessler, 1999; Richter et al., 2009; Mutke et al., 2014). These regions are also regarded as both museums and cradles of biodiversity, where old taxa have survived because of relatively stable climates or the avoidance of climate change impacts by altitudinal range shifts. Additionally, it is possible that new taxa are being rapidly generated because of new ecological opportunities caused by recent uplifts (e.g. Puya, see Givinish et al. 2011; Andean tillandsioids, see Givinish et al., 2008, 2014). In combination with limited gene flow and effective dispersal barriers, it has been argued that this has led to considerable radiations in many clades resulting in high numbers of rangerestricted species (Hughes \& Eastwood, 2006; Kier et al., 2009). 
Within the mosaic of high mountains and deep inter-Andean dry valleys the cloud forests are found on the eastern Andean slopes and extend from Venezuela to northwestern Argentina (Ojeda et al., 2008). Andean cloud forests are considered among the most biologically diverse ecosystems in the world (Gentry, 1992) with high endemicity for a number of taxa such as birds (Cracraft, 1985; Fjeldså \& Mayer 1996), rodents (Emmons, 1997), orchids (Vásquez \& Ibisch, 2000; Vásquez et al., 2003), vertebrates (Swenson et al., 2012), Coleoptera: Cerambycidae (Perger \& Guerra, 2013), fungi (Geml et al., 2014) and angiosperms (e.g., Campanulaceae; Lagomarsino et al., 2014). Besides new studies have been revealing recent discoveries, especially for Tucumán-Bolivian forests in south Bolivia such as group of insects (Gareca \& Blandin, 2011; Blandin \& Gareca, 2011, Wolfe \& Herbin, 2002; Perger \& Guerra, 2012), rodent (Ferro et al., 2010) and plants (Steudel, 2011; Särkinen et al., 2015). Despite the high diversity and endemicity found in the cloud forests, there have been few studies about their diversity and spatial distribution of taxa as well as the processes of diversification (Lagomarsino et al., 2014). In Peru and Bolivia the cloud forests are referred as Yungas. These forests are found all along the eastern side of the Central Andes following the eastern slopes of the Marañón river in Peru to central Bolivia, between the Moist Puna to the west and the lowlands of the Amazon to the east (Cabrera \& Willink, 1973). The southern extreme of the Yungas forests is replaced by a distinctive assemblage of plant species in southwestern Santa Cruz Department and extends over isolated northsouth oriented mountain chains in Chuquisaca and Tarija departments to northwestern Argentina (Churchill \& Lozano, 2009). To the west, it is bounded by the Xeric Puna and to the east by the Bolivian Chiquitanía and the Gran Chaco (Josse et al., 2009). These forests, which had already been considered belonging to the Yungas (lbish et al., 2003), nowadays are recognized as a distinct subdivision of the Yungas and often designated as Tucumán-Bolivian forest (Schulenberg, 1997).

An angiosperm genus that is particularly rich in these Andean vegetations is Schinus L. It comprises ca. 42 species endemic to South America, ranging from the central Andes to southern South America, with exception of $S$. areira L. and $S$. terebinthifolia Raddi, which are native to this region but have become widespread invasive species outside their native range. Its species are distributed along the Andes in Chile, Argentina, Bolivia and Peru, where they can be found in the interAndean valleys and cloud forests as well as at low altitudes from southeastern to northeastern Argentina, extending into Uruguay, Paraguay and southern Brazil. Noteworthy is their maximum known elevation, in particular the cloud forest Schinus species have the highest elevation Anacardiaceae in world reaching an altitude up 
3,900 m, whereas majority of other Anacardiaceae taxa occur in lowland habitats. A few endemic Chilean species occur also in sclerophyllous forests under a Mediterranean climate. The phylogenetic study of Schinus (Silva-Luz et al., in prep., see Chapter 1) demonstrated strong congruence between phylogeny and geography suggesting that vicariance (Sanmartín, 2014) may have played a major role in the biogeographical processes that might led to the current distribution of its species. Within the phylogenetic tree of Schinus, the simple-leaved species were recently resolved into five relatively well-supported clades referred to here as the Sclerophyll Forest clade (Schinus section Duvaua), the Patagonia and pre-Puna clade (Schinus section Montana), the Montane Cloud Forest clade (Schinus section Myrtifolia), the arid areas clade (Schinus section Pilifera), and the Atlantic clade (Schinus section Atlantica). This study is the first phase of a long-term effort to treat all species of the genus. Here, we focus on a taxonomic revision of Schinus sect. Myrtifolia, a monophylum that comprises endemic species from cloud forests of Peru, Bolivia and Argentina, and we describe four new species which are concentrated mainly in Tucumán-Bolivian forests from southern Bolivia.

\section{Material and Methods}

This study was based on fieldwork and examination of herbarium specimens from BA, BAA, CTES, GH, ICN, LP, MBM, MCNS, MO, NY, SI, SP, LPB, RB, SPF, US (herbarium acronyms follow Index Herbariorum). In addition, we supplemented this with field collections and observations in Argentina, Bolivia and Peru. Measurements were made from dried herbarium material. Colors of flowers and fruits are described from living material or from herbarium label data. We constructed data sets with geographical information of the municipalities when the geographic coordinates were not available on the collections examined. Extent of Occurrence (EOO) and Area of Occupancy (AOO) were calculated using GeoCat (www.geocat.kew.org) with a $2 \mathrm{~km}^{2}$ cell size for AOO calculation. Ecological data on vegetation types were gathered from herbarium collections and from observations during field work. Common names and phenological information were taken from exsiccatae labels and literature. Conservation status of each species was assessed using the criteria of the IUCN (2014) based on the GeoCat analyses (Bachman et al., 2011) combined with field knowledge. Even though it can be complicated the application of a species concept, we adopted here the genotypic cluster definition, in which groups of individuals with shared features are separable from other clusters by morphological discontinuities or few intermediates when in contact (Mallet, 1995). Since statistic analysis such as those using morphometrics were not carried out, we 
have not recognized varieties, but have rather described the variation where present. The delimitation of Schinus species of this section was made using a character set based mainly on inflorescence structures and leaf features, especially the venation. Vegetation types cited in comments of each species as well as the distribution maps follow classification system based on ecoregions (lbish et al., 2003; Olson et al., 2001). However, for comparison purpose among taxa from xeric and mesic enviroments, we call vegetation types in a broader sense. In this way Puna and pre-Puna correspond to ecoregion areas of Central Andean dry punas, Central Andean punas and Central Andean wet punas, the dry inter-Andean valleys is assigned to Bolivian montane dry forests, and Yungas correspond to areas of Bolivian and Peruvian Yungas (Fig. 1C).

\section{Taxonomic treatment}

Schinus sect. Myrtifolia Silva-Luz \& J.D. Mitch., sect. nov. - Type: S. myrtifolia (Griseb.) Cabrera (三 Cybianthus myrtifolius Griseb.).

= Schinus subgenus Duvaua (Kunth) F.A. Barkley, pro parte, Brittonia 5(2): 165. 1944, syn. nov. I Duvaua Kunth, Annales des Sciences Naturelles (Paris) 2: 340. 1824 三 Schinus subgenus Duvaua sect. Duvaua pro parte, Brittonia 5(2): 165. 1944, syn. nov. - Type: S. polygama (Cav.) Cabrera (三 Amyris polygama Cav.).

$=$ Schinus subgenus Duvaua sect. Pseudoduvaua F.A. Barkley pro parte, Brittonia 5(2): 179. 1944. syn. nov. - Type: S. latifolia (Gillies ex Lindl.) Engl. (三 Duvaua latifolia Gillies ex Lindl.).

Description. Dioecious tree(lets) or shrubs. Branches erect or prostrate, unarmed or rarely branchlets ending in inconspicuous or conspicuous thorns, lenticellate. Trichomes simple, barbed, barbellate, bulbous or clavate-glandular, erect, sometimes appressed, falcate, nutant, sigmoid or straight, transparent, sometimes cream-colored. Leaves simple, alternate, sometimes clustered; petiole canaliculate or semi-terete; margin entire or crenate, crenate-serrate, or erose (usually only on distal portion), rarely lobed on distal portion, flat, revolute or undulate; leaf texture usually drying brown or greenish, paler below; primary venation pinnate; secondary vein framework cladodromous; marginal secondary vein present, sometimes inconspicuous; tertiary veins freely ramified, sometimes not 
visible; stomata often visible on abaxial surface. Inflorescences axillary or terminal, fasciculate, the male inflorescences pseudoracemes or thyrsoids, rarely panicles, cymes or flowers solitary, axes often branched at base and densely branched distally; the female inflorescences usually pseudoracemes, sometimes thyrsoids, rarely flowers solitary; axes green, greenish-yellow or cream-colored; bracts monomorphic or sometimes dimorphic on staminate flowers, plicate; pedicel often articulated, sometimes the articulation indistinct, green. Flowers unisexual, diplostemonous; sepals 4, united at base, aestivation apert, green; petals 4, free, aestivation imbricate, cream-colored or white, with 1 midvein that sometimes branches near apex and 1-3 cladodromous secondary veins, spreading at anthesis, usually recurved. Staminate flowers: antesepalous stamens longer than the antepetalous ones; anthers yellowish; disk annular, 8-lobed or -sulcate, yellow, glabrous or rarely hirsute; pistillode ovoid and acuminate, with an abortive ovule, stigmas not developed, often red. Pistillate flowers: antesepalous staminodes often longer than antepetalous ones; anthers small and sterile; disk annular, often forming a rim; pistil green, reddish-green or red; ovary globose, often laterally compressed; style with 3 slightly bilobed, capitate stigmas; ovule anatropous, pendulous, funicle subapically attached. Drupes with a thin, friable exocarp when dry, splitting from the resinous mesocarp, red, pink or pinkish-red and globose, ovoid or obovoid, often laterally compressed, sometimes the apex slightly oblique, sometimes the surface with visible stomata; sepals, petals, staminodes and stigmas persistent.

Distribution and Ecology. Species of Schinus sect. Myrtifolia are found on the northeastern slopes of Peru, Bolivia and Argentina. Most of species of this section as $S$. gracilipes, $S$. meyeri, $S$. myrtifolia and $S$. venturii together with the majority of the new species, $S$. obliqua, $S$. tarijensis and $S$. villosa are endemic to the Tucumán-Bolivian forests (Fig. 1B,C). These forests, also known as Las Yungas (Ibisch et al., 2003), extend isolated from Santa Cruz along north-south oriented mountains chain in Chuquisaca and Tarija departments to northwestern Argentina. Southern boundary of the Tucumán-Bolivian forests is in northern Catamarca Province (Churchill \& Lozano, 2009). In Santa Cruz there is a dramatic floristic change, in a region known as the elbow of the Andes. In this region the TucumánBolivian forests are replaced by Yungas or Los Yungas which are restricted to westcentral Bolivia extending into Peru (Cabrera \& Willink, 1973; Ibisch et al., 2003). Schinus congestiflora and S. minutiflora occur both in the Tucumán-Bolivian forests and Yungas forests (Fig. 1B,C). Yungas and Tucumán-Bolivian forests are surrounded by a matrix of arid vegetation types which becomes bordered by Puna or pre-Puna in the west slope of the Andes and by montane Chaco and Bolivian 
Chiquitanía on the eastern slopes (Ibisch et al., 2003; Josse et al., 2009). Another arid vegetation type which occurs scattered among these ecoregions are the interAndean dry forests, especially the Piedmont dry forests (Banda et al., 2016). Schinus microphylla and $S$. subtridenta have contrasting pattern of distribution compared to other species of $S$. sect. Myrtifolia occurring mostly in areas of prePuna, Puna and dry inter-Andean valleys of Peru and Bolivia. Schinus microphylla also occurs disjunct in the Peruvian Yungas (Fig. 1B,C). The Yungas forests are tropical or subtropical habitats with higher humidity and less seasonality than the Tucumán-Bolivian forests. This difference in climate is due to the northeastern exposure which benefits from high humid trade winds.
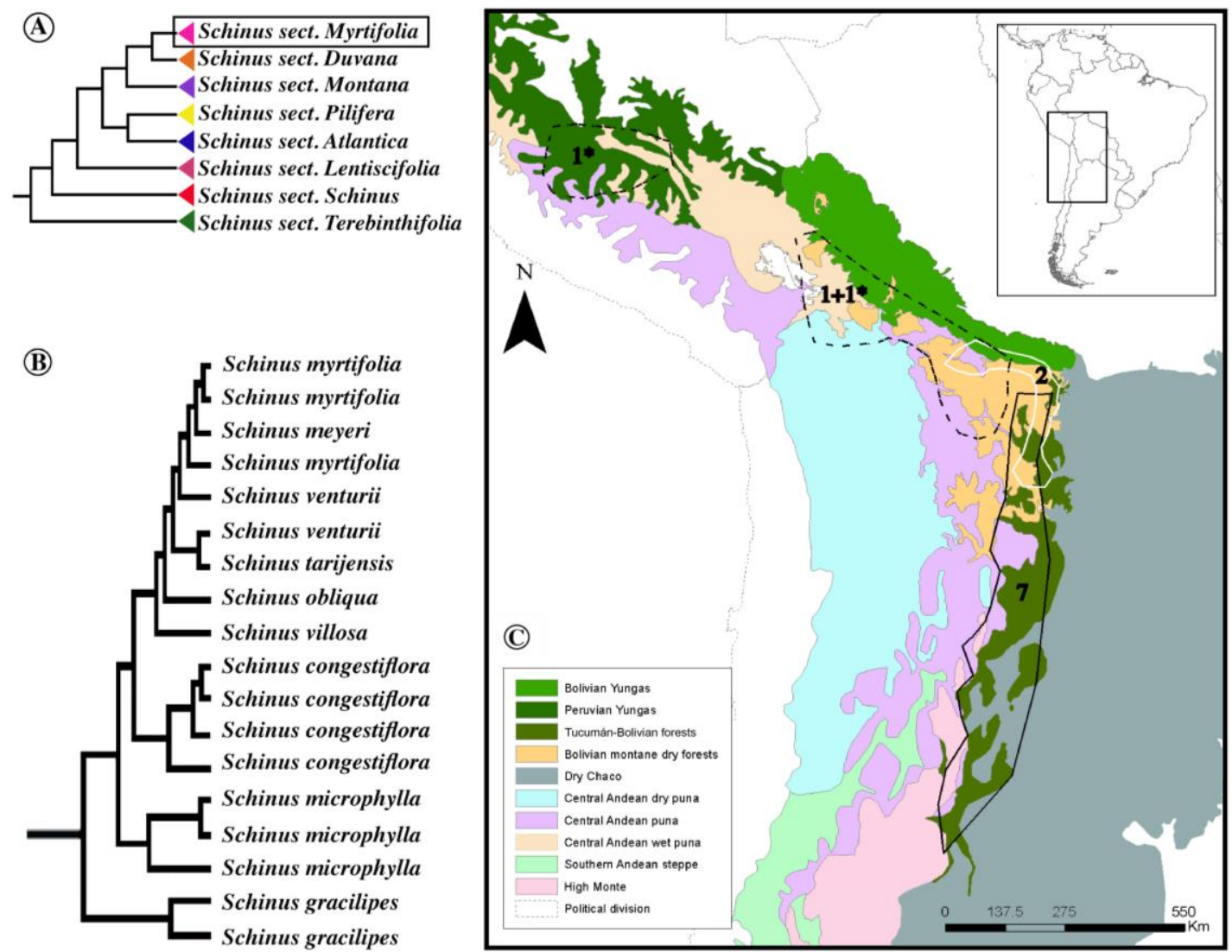

Fig. 1. A: Simplified Bayesian half-compatible consensus of Schinus phylogeny based on the combined pool of post-burn trees from analyses of the combined plastid and nuclear DNA regions, highlighting the position of $S$. sect. Myrtifolia (modified from Silva-Luz et al. in prep.). B: Phylogeny of Schinus sect. Myrtifolia (extracted from Silva-Luz et al. in prep.). C: Geographical distribution of Schinus sect. Myrtifolia on Argentinean, Bolivian and Peruvian Montane Cloud Forests; solid black line represents the distribution of $S$. gracilipes, S. meyeri, S. myrtifolia, S. obliqua, S. tarijensis, S. venturii and $S$. villosa in the Tucumán-Bolivian Forests; solid white line represents the distribution of $S$. congestiflora and S. minutiflora in both Tucumán-Bolivian Forests and Yungas; dashed black line represents the distribution of $S$. microphylla and S. subtridentata in pre-Puna, Puna and dry interAndean valleys, and also the disjunct distribution of $S$. myrtifolia in the Peruvian Yungas. Numbers inside the polygon represent number of species occurring in each area. Asterisk indicates the only species shared in both Bolivian and Peruvian Yungas (S. microphylla). 
These forests occupy a broad altitudinal range, between 500-4,000 m, within which two altitudinal zones can be distinguished: 1 - the sub-Andean belt below 2,000 $\mathrm{m}$ in elevation; 2- the cordilleran belt, above 2,000 m where most of the Schinus taxa occur (between 1,700-3,800 m). The cordilleran belt includes the montane, the upper-montane and the lower portions of the high Andean zone (Josse et al., 2011). The Tucumán-Bolivian forests have a north-south orientation and suffer much more directly from the southerly cold fronts, also called as surazos (Ibisch et al., 2003). These forests are subtropical humid habitats and occur between $600 \mathrm{~m}$ to slightly less than 4,000 $\mathrm{m}$ in elevation, however most of this ecoregion occupies the subAndean belt below 2,000 $\mathrm{m}$ in elevation (Josse et al., 2011). According to Brown et al. (2005) this ecoregion is divided into three major forest types differentiated by altitude: the piedmont forest (400-700 m), the montane forest $(700-1500 \mathrm{~m})$ and the montane cloud forest $(1,500-3,000 \mathrm{~m})$ where most of the Schinus species occur. Studies concerning the elevational pattern of richness or endemism in the cloud forests have suggested the relevant role of taxon-specific patterns (Kessler, 2002). This pattern suggests that some taxa have a phylogenetically determined propensity for survival under extreme conditions (Kromer \& Kessler, 2005). For instance, studies of vascular epiphytes from Bolivia have demonstrated richness peak at midelevation (ca. $1500 \mathrm{~m}$ alt.) and richness declines at higher elevations. Despite the montane cloud forests have high air humidity, which is invoked as an important factor determining epiphytic plant diversity, seemingly that the decline of diversity at high altitudes is related to low temperatures rather than to air humidity (Kessler, 2001a; Kessler et al., 2001; Kromer \& Kessler, 2005). In contrast, species of Schinus sect. Myrtifolia occur mostly in montane cloud forests, between 1,400-3,800 $\mathrm{m}$ in elevation, except for $S$. gracilipes which also can be found at lower elevations $(750-2,900 \mathrm{~m})$. The pattern observed in mostly Schinus taxa of this section occupying high elevations suggests that the distributions of its species are limited to areas with relatively low temperatures and these species are likely to be frost tolerant. In addition, a narrow altitudinal range with species restricted to higher elevations may also be related to the fact that these species inhabiting the steep, topographically complex slopes which have narrow, fragmented ranges and hence tend towards local endemism (Kessler, 2001b). A species occurring in high altitudes would also to overcome greater distance to reach other mountains. This fact would allow a relative isolation of the montane forests from adjacent valleys, and as consequence generating endemism (Sklenàr \& Jørgensen, 1999). There is increasing evidence for the major role that abiotic factors as Andean elevation and climate changes may have played on speciation and extinction rates of several plant 
lineages (e.g. Hughes \& Eastwood, 2006 for Lupinus; Lagomarsino et al., 2016 for Campanulaceae-Lobelioideae). The spatial and diversity patterns of species of Schinus sect. Myrtifolia may also reflect a similar scenario and deserve further investigation.

Schinus sect. Myrtifolia species co-occur with the evergreen Podocarpus and Weinmannia forests as well as in deciduous forests with Alnus acuminata. On steep slopes, at higher elevations Schinus species also occur with remmant and relictual Polylepis forests. At lower elevations (between 1,000-1,500 m), Schinus from this section also occur in Myrtaceae forests, especially with Myrcianthes spp.

Overall, species of Schinus occur in subtropical or temperate climates where they may grow under drought, cold, and even to frost conditions. Even though species of Schinus sect. Myritifolia occur in mesic environments, the majority of these taxa are characteristic of Tucumán-Bolivian forests, which are under more arid and colder climates than Yungas, and they also occur at high elevations, which suggests the maintenance of a climatic niche in Schinus. Besides, it seems that forests from the higher altitudinal belts (e.g. montane cloud forests) constitute the northern range limit to the Schinus species of simple-leaved. Studies have reported a north-south decline in species diversity along the Tucumán-Bolivian forests (Morales et al., 1995; Kessler, 2000; Brown et al., 2001) or addressed questions regarding to this pattern of biodiversity decline (Ojeda et al., 2008). However, future investigations could evaluate whether or not the Tucumán-Bolivian forests are also correlated to the northern boundary or an intermediate lower-lying areas into northern arid and cold environments as Puna and pre-Puna for other southern South American biota as they seem to the Schinus species of simple-leaved. The current geographical distribution of these taxa may be related to climatic tolerances which could limit dispersal of temperate lineages into lowland tropical regions.

Schinus sect. Myrtifolia taxa are geographically and ecologically structured, where most of species occur in Tucumán-Bolivian forests and only two species in both Tucumán-Bolivian and Yungas forests. Also, two species occurring mostly in areas of pre-Puna, Puna and dry inter-Andean valleys (Fig. 1B,C), and $S$. microphylla has disjunct distribution occurring in arid vegetation types in Bolivian and in the Peruvian Yungas. Distribution patterns observed in Schinus sect. Myrtifolia seem to corroborate the Tucumán-Bolivian forests as a distinct ecoregion which presents a recognizable ecological, floristic and biogeographical patterns, as well as a great number of endemics (Cabrera \& Willink, 1973; Ibisch et al., 2003). Furthermore, the phylogenetic study of Schinus (Silva-Luz et al., in prep., see Chapter 1) evidenced a Schinus clade (Fig. 1A,B) that comprises mainly endemic 
species of Andean cloud montane forests, more specifically from the TucumánBolivian and Yungas forests (Fig. 1C).

Systematics and taxonomy. Taxa belonging to Schinus sect. Myrtifolia were previously recognized by Barkley as part of $S$. subg. Duvaua sect. Pseudoduvaua, with exception of $S$. microphylla, a species formerly positioned in $S$. subg. Duvaua sect. Duvaua (Barkley, 1957). According to Barkley's circumscription, species from the former section are distinguished from taxa of latter section on account of their unarmed branches. Nevetheless the phylogenetic analysis of Schinus indicated that thorny branches is a homoplastic character state which appeared independently at least five times within the Schinus simple-leaved lineage (Silva-Luz et al. in prep., see Chapter 1). For instance, $S$. microphylla, $S$. subtridentata (S. sect. Myrtifolia), S. odonellii F.A. Barkley, S. marchandii F.A. Barkley, S. roigii Leal \& Cabrera (S. sect. Montana Silva-Luz \& Pirani) and $S$. polygama (Cav.) Cabrera (S. sect. Duvaua Marchand emend. Silva-Luz) are not nested within S. sect. Pilifera Silva-Luz \& J.D. Mitch. or S. sect. Atlantica Silva-Luz \& Pirani, clades which comprise only armed species (Fig. 1A). Thereby, a novel morphological character set was compiled to characterize these sections (Silva-Luz et al., in prep., see Chapter 1). Even though the clade comprising species of $S$. section Myrtifolia is strongly supported by Maximum Parsimony, Maximum Likelihood and Bayesian analyses, the relationship between S. myrtifolia, S. meyeri, S. venturii, S. tarijensis and $S$. obliqua are not yet entirely clear or supported. In addition, the sampling of this clade is still incomplete, since $S$. subtridentata and $S$. minutiflora could not be sampled. Based on morphological analysis, we hypothesize that the former species is nested close to $S$. microphylla, whereas the latter species is closely related to $S$. congestiflora. Further systematic and evolutionary studies should considerate using a phylogenomic approach, since our reconstruction of the Schinus phylogeny showed a low level of genetic divergence among individuals of recent co-ancestry, which is likely due to speciation events closely spaced in time. Also, phylogeographical studies seem to be promising to a better understanding of macro and microevolutionary processes involved in the Peruvian, Bolivian and Argentinean montane cloud forests biota.

Delimitation problems related to species of this section were reported for $S$. andina (Engl.) I.M. Johnst., an illegitimate name (see discussion of S. microphylla) and S. microphylla. Macbride (1951) suggested to recognize $S$. andina as a variety under S. microphylla, whereas Barkley (1957) in the $S$. andina comments pointed out the presence of intermediate individuals between $S$. microphylla and $S$. myrtifolia. Our morphological study of Schinus sect. Myrtifolia specimens revealed a 
significant number of taxonomic circumscription problems. For example, many specimens, especially those from Bolivia, have been identified as either $S$. andina or S. myrtifolia. However, a wide variation in character states was observed in specimens determined either as the former or the latter. Detailed morphological study of numerous of exsiccatae indicates that specimens previously identified as $S$. andina or $S$. myrtifolia can be divided into seven species which we recognize as $S$. microphylla s.s., S. subtridentata, S. minutiflora, S. tarijensis, S. congestiflora, S. villosa and $S$. myrtifolia. Among these taxa, two correspond to new combinations ( $S$. subtridentata and $S$. minutiflora) and three new taxa are described here ( $S$. tarijensis, S. congestiflora and S. villosa).

Our new species circumscription is primarily based on a combination of morphological character set (we adopted the genotypic cluster definition, Mallet 1995), with the molecular evidence and with distinctive geographic distributions, even though some degree of overlap is observed in a few cases. Schinus microphylla occurs in Peru and Bolivia (Fig. 7C) and it is readily distinct from its congeners by its conspicuous thorny branches (Fig. 4E, 5A,C), leaves with the secondary vein angle decreasing smoothly toward base (Fig. 4E, 5A,B) and staminate inflorescences with internodes measuring $1.7-3.5 \mathrm{~mm}$ at the median portion (Fig. 5D). Nevertheless, some specimens from Bolivia may also bear inconspicuous thorny branches. Schinus myrtifolia occurs in northwestern Argentina with scattered populations in southern Bolivia (Fig. 7B). This species is mostly distinct by its long unbranched pseudoracems (Fig. 5F, 6E). Schinus congestiflora is a new taxon that occurs in Bolivia, from Santa Cruz to Cochabamba (Fig. 7D). It is characterized by its long and unarmed branches (Fig. 4A,C), mostly uniform leaves that are essentially obovate and chartaceous (Fig. 2A,D,F), staminate inflorescences branched at base and densely branched distally (Fig. 4B). Schinus subtridentata, a new combination based on Schinus huyngan var. subtridentata, occurs in La Paz, Chuquisaca and Cochabamba departments of Bolivia (Fig. 7C) and has inconspicuously armed branchlets (Fig. 8N), leaves (Fig. 8I,L,M) of variable shape (obovate, ovate or oblong) that are usually coriaceous (ocasionally chartaceous) and small inflorescences (Fig. 8I,J). Schinus tarijensis is another new taxon that was formerly confused with $S$. andina or $S$. myrtifolia. It is only known from southern Bolivia, occurring in Tarija (Fig. 7A) and is characterized as a small shrub 1-3.5 $\mathrm{m}$ tall, with pistillate flowers bearing densely hirsute or clavate-glandular pistils of 1.4-1.5 mm in length overall (Fig. 8E,F), and drupes 6-7 x 6.2-8 mm with similar indumentum or sometimes glabrescent (Fig. $8 \mathrm{H})$. Schinus minutiflora constitutes a new binomial name based on Schinus dependens var. andina fo. 
grandifolia, occurring in Chuquisaca, Cochabamba, La Paz and Santa Cruz, in Bolivia (Fig. 7D). This species is distinguished from the other taxa by its frequently broadly ovate leaves with the secondary vein angle increasing smoothly toward base (Fig. $2 \mathrm{H}-\mathrm{I}, \mathrm{L}-\mathrm{N}$ ) and its diminutive inflorescences (Fig. $2 \mathrm{H}, \mathrm{J}$ ). Schinus villosa is a new species, occurring in Chuquisaca and Santa Cruz, in Bolivia (Fig. 7B) and is distinguished from all other species by its villous indumentum on branches, leaves and inflorescences (Fig. 9H-M).

Delimitation issues were also noticed among specimens of $S$. meyeri and $S$. venturii. Detailed morphological study also evidenced characters that allowed the recognition of a distinct taxon described here, $S$. obliqua, formerly confused with the those two species on account of a similar shape leaf (often ovate, sometimes lanceolate) and overlap in habitat and distribution (Fig. 7A,B). The new species can be distinguished from the two other ones because of its leaves medially asymmetrical, and both surfaces clavate-glandular, hirsute or villous, densely along veins (Fig. 9A,D,E). In contrast, S. meyeri (Fig. 3H,I,K) and S. venturii (Fig. 3M,N,Q) have leaves medially (sub)symmetrical and both surfaces sparsely clavateglandular, but on adaxial surface the midvein and proximal portion of margin puberulous.

The taxonomic novelties are here presented in Schinus sect. Myrtifolia as an attempt to disentangle its complexity and misidentified species taking into account the morphological traits of a wider sampling and a careful nomenclatural revision. In this way we hope to highlight all range of morphological variation, especially within S. andina and $S$. myrtifolia, which has been overlooked until now. However, the delimitation of species that occur in sympatry is still a difficult issue because of some degree of overlap in morphological characters, especially between $S$. congestiflora, S. minutiflora and $S$. subtridentata. Moreover, as observed in most of the simple-leaved species of Schinus, taxa from this section also display sexual dimorphism, usually represented by larger staminate inflorescences bearing an increased number of flowers than the smaller female ones. In fact this seems to be a common secondary sex pattern in dioecious angiosperms (e.g. Lloyd \& Webb, 1977). Also, within the morphological characters used to separate species from this section, the inflorescence size and the internode length at the median portion of the inflorescence have demonstrated to be useful characters for species delimitation. Overall, these inflorescence features are more conspicuous in male individuals, while female ones can share very similar inflorescence traits, especially among $S$. minutiflora, $S$. congestiflora and $S$. subtridentata. When the sexes have different optimal values for some traits (e.g. an increased number of flowers), a shared 
genetic architecture can constrain them from evolving toward their respective trait optima (Barrett \& Hough, 2013). However, sexual dimorphism can still evolve when such trade-offs exist, and this can involve sex-limited gene expression and the breakdown of strong intersexual genetic correlations. It seems that genetic variances in reproductive traits as those before mentioned are not equivalent between males and females (Barrett \& Hough, 2013). Yet, quantitative genetic investigations could provide insights about evolution of sexual dimorphism presented in the species of Schinus sect. Myrtifolia.

\section{Key to Schinus section Myrtifolia}

1 Branches ending in conspicuous or inconspicuous thorns; leaves with tertiary veins not visible; plants of humid rocky slopes of Bolivan and Peruvian prePuna, Puna or dry inter-Andean valleys or in the Peruvian Yungas ....

- Branches always unarmed; leaves with tertiary veins often visible (sometimes indistinct in S. tarijensis); plants of the Tucumán-Bolivian or Bolivian Yungas forests

2 Branch apices conspicuously thorny; leaves often congested, with abaxial surface strigose or clavate-glandular and adaxial surface glossy; secondary vein angle smoothly decreasing toward base; pistillate flowers with petals 1.3 $2 \times 1.4-1.5 \mathrm{~mm}$; antesepalous and antepetalous staminodes $0.6-0.9 \mathrm{~mm}$ long and $0.5-0.7 \mathrm{~mm}$ long, respectively; fruiting pedicel $1.5-1.8 \mathrm{~mm}$ long overall S. microphylla

- Branch apices thorny but inconspicuously so; leaves not congested, with abaxial surface hirsute or clavate-glandular and adaxial surface often dull (ocasionally glossy); secondary vein angle uniform, irregular or smoothly increasing toward base; pistillate flowers with petals 1.1-1.4 x 0.8-1 mm; antesepalous and antepetalous staminodes $0.4 \mathrm{~mm}$ long and 0.3-0.4 mm long, respectively; fruiting pedicel $2.3-2.5 \mathrm{~mm}$ long overall ..... S. subtridentata

3 Adaxial surface of leaves with secondary veins essentially flat or prominulous medially and impressed toward margin, if flat or prominulous, costal secondary veins in (11-) 14-24 pairs; tertiary veins often impressed

- $\quad$ Adaxial surface of leaves with secondary veins consistently flat or (slightly) impressed, costal secondary veins in 6-12 pairs; tertiary veins flat 8

4 Leaves (broadly) elliptic or oblong, rarely ovate; bracts monomorphic; staminate inflorescences consisting of unbranched pseudoracemes

S. myrtifolia 
- Leaves ovate, ovate-lanceolate or lanceolate; bracts dimorphic; staminate inflorescences of several types but always branched, rarely the staminate flowers solitary

5 Leaf margin crenate, crenate-serrate, twice-serrate or erose; flower pedicel articulated S. gracilipes

- Leaf margin entire or entire proximally and crenate, crenate-serrate, twice crenate or erose distally; flower pedicel apparently not articulated 6

6 Leaves medially asymmetrical, basal width markedly asymmetrical; secondary vein angle smoothly increasing toward base; both surfaces clavate-glandular, hirsute or villous, densely so along veins; fruiting pedicel villous or hirsute S. obliqua

- Leaves medially (sub)symmetrical, basal width (sub)symmetrical or asymmetrical; secondary vein angle irregular throughout; both surfaces sparsely clavate-glandular, but on adaxial surface the midvein and proximal portion of margin puberulous; fruiting pedicel puberulous or clavate-glandular

7 Leaves membranaceous, rarely chartaceous; tertiary veins conspicuous; staminate inflorescences essentially lax pseudoracemes; petals with midvein often branching from median portion toward apex S. meyeri

- Leaves chartaceous; tertiary veins inconspicuous; staminate inflorescences essentially congested pseudoracemes; petals with midvein sometimes branching only at apex

S. venturii

8 Leaves often congested; staminate flowers with the portion of the pedicel distal to articulation $1.2 \mathrm{~mm}$ long; antesepalous and antepetalous stamens 1.3 and $0.8 \mathrm{~mm}$ long, respectively; pistillode $0.8 \mathrm{~mm}$ long; pistillate flowers with pistil 1.4-1.5 mm long overall, densely hirsute or clavate-glandular; drupes 6-7 x 6.2-8 mm, hirsute or clavate-glandular, sometimes glabrescent .. S. tarijensis Leaves not congested; staminate flowers with the portion of the pedicel distal to articulation $0.5-0.7 \mathrm{~mm}$ long or the articulation indistinct; antesepalous and antepetalous stamens $0.8-1$ and 0.5-0.7 mm long, respectively; pistillode 0.3$0.5 \mathrm{~mm}$ long; pistillate flowers with pistil $0.7-0.8 \mathrm{~mm}$ long overall, glabrous; drupes 4-5.5 x 4.5-6.4 mm, glabrous 9

9 Trichomes cream-colored; leaf basal insertion asymmetrical; both surfaces of leaves usually densely villous, hirsute or clavate-glandular or sometimes sparsely pubescent; midvein prominent abaxially; bracts dimorphic, bracts and bracteoles densely villous abaxially, glabrous adaxially; both surfaces of the 
petals pilose along midvein and margin, otherwise sparsely tomentose or glabrous; drupes obliquely ovoid S. villosa

- $\quad$ Trichomes transparent; leaf basal insertion (sub)symmetrical; both surfaces glabrous, puberulous or sparsely clavate-glandular, rarely sparsely hirsute; midvein prominent or prominulous on proximal portion and prominulous or flat toward apex or occasionally midvein flat abaxially; bracts monomorphic, bracts and bracteoles puberulous, densely pilose or clavate-glandular on both surfaces; both surfaces of the petals essentially glabrous, sometimes minutely puberulous along midvein; drupes symmetrically ovoid 10

10 Orthotrophic branches; leaves usually (broadly) obovate, sometimes ovate or oblong, rarely orbicular; staminate and pistilate flowers with pedicel 1.3-2.5 $\mathrm{mm}$ and 1.1-2.5 mm long, respectively; pistillate flowers with pistil 0.7-0.8 mm long overall S. congestiflora

- $\quad$ Plagiotrophic branches; leaves usually (broadly) ovate, sometimes elliptic or obovate; staminate and pistilate flowers with pedicel (0.5-) 0.9-1.5 mm and 0.8-0.9 mm long, respectively; pistillate flowers with pistil 0.9-1.1 $\mathrm{mm}$ long overall S. minutiflora

1. Schinus congestiflora Silva-Luz \& Pirani, sp. nov. - Type: Bolívia, departamento Santa Cruz, província Florida, 6 km (by air) NE of Mairana, Campamento La Yunga, 1805’40”S, 635'W, 1950 m alt., 21 July 1994, M. Nee 45301 (holotype: LPB!; isotypes: MO!, NY!).

Figures: 2 A-G, 4 A-C, 7 D

Diagnosis. Shrubs or tree(lets) 1-3 m tall, similar to $S$. tarijensis and $S$. minutiflora because of their unarmed branches, nearly equivalent leaf dimensions and inconspicuous tertiary veins. Schinus congestiflora differs from the before mentioned taxa by its larger staminate inflorescences $5-13 \mathrm{~mm}$ long (vs. 4-7 mm long and 6-7 mm long, respectively). It resembles $S$. myrtifolia because its staminate inflorescences overlap in length 5-13 mm long (vs. 3-14 mm long in S. myrtifolia). Schinus congestiflora differs from $S$. myrtifolia by its congested staminate pseudoracemes often branched at base and densely branched distally, whereas $S$. myrtifolia has lax and unbranched staminate pseudoracemes. The pistillate inflorescences of $S$. congestiflora has $0.5-1 \mathrm{~mm}$ long internodes on the median portion, whereas pistillate inflorescences of $S$. myrtifolia has 2-3.5 $\mathrm{mm}$ long median internodes. 
Description. Shrubs or tree(lets), 1-5 m tall. Branches erect, unarmed, pilose or puberulous. Trichomes simple or barbellate and transparent, or clavateglandular and transparent or orangish-brown; erect or appressed, straight, arcuate, nutant or slightly sigmoid, 0.04-0.1 mm long on branches and leaves, and $0.04 \mathrm{~mm}$ long on inflorescences. Leaves not congested; petiole 1-5 mm long, canaliculate or semi-terete, on abaxial surface puberulous or pilose, on adaxial surface puberulous or clavate-glandular; blade (0.7-0.9-) 1.5-3 (-3.5) x 1-1.6 (-1.9-2.2) cm, essentially (broadly) obovate, sometimes ovate or oblong, rarely orbicular; apex obtuse, rounded, rarely truncate; medially (sub)symmetrical, basal insertion (sub)symmetrical, base width symmetrical or asymmetrical, acute, rarely obtuse, rounded or decurrent; margin entire or entire on proximal portion, crenate or crenate-serrate on distal portion, slightly revolute on proximal portion, conspicuously puberulous or clavate-glandular, especially at base; texture chartaceous, dull; costal secondaries in 6-8 pairs, spacing often irregular, course straight, arcuate or sinuous, angle uniform or irregular; marginal secondary vein $0.08-0.2 \mathrm{~mm}$ in width, conspicuous; tertiary veins barely visible; on abaxial side the midvein prominent or prominulous proximally and prominulous or flat distally, secondary veins often flat, sometimes impressed, tertiary veins flat, puberulous or clavate-glandular on midvein, especially at base, rest of surface sparsely clavate-glandular, sometimes puberulous, rarely hirsute; on adaxial side the midvein prominulous proximally and impressed distally, secondary veins slightly impressed or flat, tertiary veins flat, sparsely clavate-glandular. Inflorescences axillary or terminal, clavate-glandular or puberulous; bracts monomorphic, 0.3-0.7 x 0.5-0.8 mm, deltate; bracteoles 0.2-0.3 x 0.1-0.2 mm, ovate; bracts and bracteoles puberulous or clavate-glandular on both surfaces, conspicuously glandular on margin; pedicel puberulous or clavateglandular, bracteoles subtending pedicel; sepals pilose or puberulous on both surfaces, conspicuously clavate-glandular on margin; petals with midvein often branching at apex and 1-2 cladodromous secondary veins, essentially glabrous, sometimes minutely puberulous at midvein on both surfaces; disk 0.1-0.4 mm tall and ca. $0.08 \mathrm{~mm}$ thick, glabrous. Staminate inflorescences $5-13 \mathrm{~mm}$ long, flowers in congested pseudoracemes, often branched at base and densely branched distally, median internodes $0.5-1.5 \mathrm{~mm}$ long. Staminate flowers with pedicel 1.3-2.5 mm long overall, portion distal to articulation $0.5-0.7 \mathrm{~mm}$ long or the articulation not visible; sepals 0.3-0.6 x 0.4-0.8 mm, ovate or deltate; petals $1.3-1.6 \times 1-1.2 \mathrm{~mm}$, ovate, convex; antesepalous and antepetalous stamens 0.8-1 and 0.5-0.7 mm long, respectively; anthers $0.3-0.4 \mathrm{~mm}$, (broadly) oblong or ovate in dorsiventral view, oblong in lateral view; pistillode 0.3-0.4 mm long. Pistillate inflorescences 3-14 mm 
long, flowers in lax pseudoracemes, median internodes $0.5-1 \mathrm{~mm}$ long. Pistillate flowers with pedicel 1.1-2.5 mm long overall, the articulation not visible; sepals 0.30.5 x 0.5-0.6 mm, ovate; petals 1-1.2 x 0.6-0.9 mm, ovate or oblong, concave; pistil 0.7-0.8 mm long overall, glabrous; ovary globose, style $0.1 \mathrm{~mm}$ long or indistinct; antesepalous and antepetalous staminodes 0.3-0.4 mm long and 0.2-0.3 mm long, respectively, anthers 0.1-0.2 $\mathrm{mm}$ long. Fruiting pedicel $1.5-2.5 \mathrm{~mm}$ long overall, portion distal to articulation $0.7-0.8 \mathrm{~mm}$ long or the articulation not visible, puberulous, pilose or clavate-glandular. Drupes 4-5.5 x 4.5-6.4 mm, red, globose, laterally compressed, glabrous.

Specimens examined. BOLIVIA. Cochabama: Carrasco, rota 7 de Santa Cruz a Cochabamba, ca. 4 km de Monte Punku, 17³4'25.2”S, 65¹8'55.8'W, 2958 m alt., 13 Jan 2014, C.L. Silva-Luz \& L.F Luz 250, fr. (NY, RB, SPF); rota 7 de Santa Cruz a Cochabamba, ca. 4 km de Monte Punku, 17³4'13.5”'S, 65¹9'53.0”'W, 3053 m alt., 13 Jan 2014, C.L. Silva-Luz \& L.F. Luz 251, fl. (NY, RB, SPF); localidad de Palca, $10 \mathrm{~km}$ al norte de la carretera antigua, entre Valle Hermoso y Totora, 1744'16”S, 6457'22”'W, 2500-2830 m alt., 12 Oct 2008, I. Linneo \& M. Mendizabal 1536, fl. (MO); Siberia, J.P. Altamirano et al. 474, fr. (MO); $63.5 \mathrm{~km}$ al este del puente sobre el rio Pucara (Punata) por el camino entre Cochabamba y Santa Cruz (9.2 km al oeste del camino a Pocona), 17³2’S, 65²2’W, 3000 m alt., 4 Feb 1987, J.C Solomon \& R.M. King 15916, fl. (LPB, MO, NY); Sehuencas, proximo al pueblo de Montepunku, 1745'02”S, 6501'43”'W, 2610 m alt., 26 Sept 2007, J.Teran et al. 1303, fl. (BOLV, MO); Cocapata, old road from Cochabamba to Santa Cruz, km 114, 24 July 1994, P. Acevedo-Rodriguez 6574, fl. (NY); km 135 hacia Totora, proximadades del lugar llamado Cañada Hornillas, 3000 m alt., 21 March 1999, M. Mercado 2087, fl. (NY). Esteban Arce, camino hacia

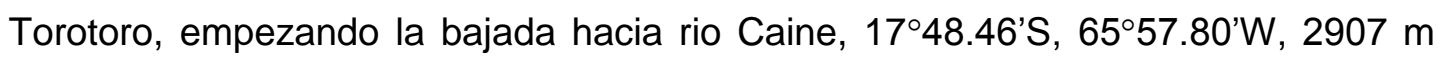
alt., 2 Jan 2005, J.R.I. Wood et al. 21299, fl. (LPB); Tarata, lands of Humberto Gandarillas, near Anzaldo, 3600 m alt., 8 Jan 1943, M. Cardenas et al. 7605, fr. (MO). Mizque, proximidades a la comunidad de Coto-Coto, 19 Feb 1999, M. Mercado 2048, fr. (NY); 23.9 km E of Epizana on carretera Fundamental 4, $9500 \mathrm{ft}$. elev., 5 Dec 1975, C. Davidson 3767, fl., fr. (MO). Quillacollo, estrada de terra em direção à Morochata, 17¹7'05.8”'S, 66¹8'38.6”W, 3191 m alt., 14 Jan 2014, C.L. Silva-Luz \& L.F. Luz 252, fl., fr. (NY, RB, SPF). Santa Cruz: Florida, ridgetop called Musural Loma ata Abra La Cruz, 4 km (by air) NE of Mairana, $18^{\circ} 06^{\prime} \mathrm{S}, 63^{\circ} 54^{\prime} \mathrm{W}$, 2050 m alt., 2 June 1991, M. Nee 40732, fl. (LPB, NY); 7 km (by air) NE of Mairana, on dirt road northeast of “Yungas", 1805'S, 635' W, 2100 m alt., 2 June 1991, M. 

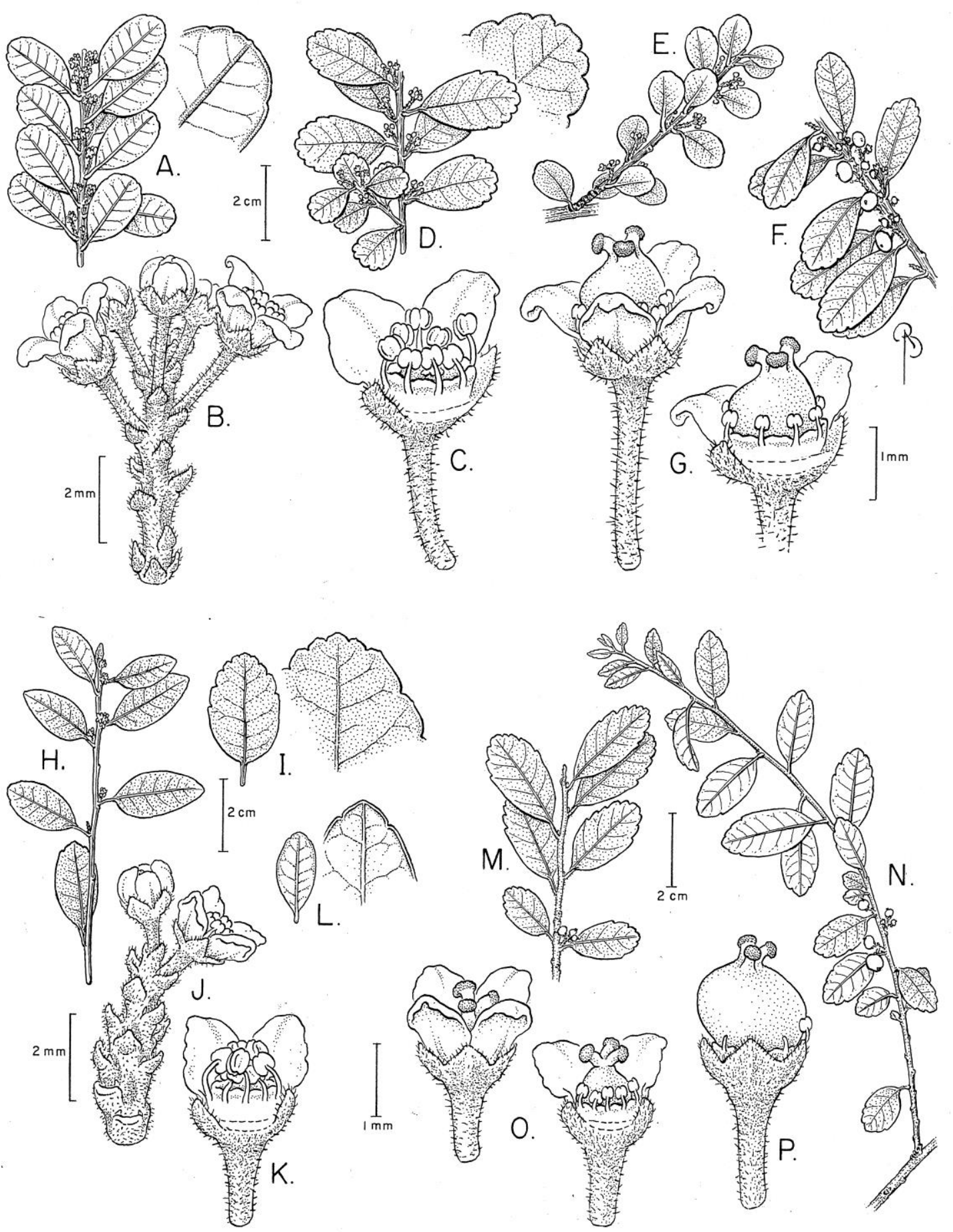

Fig. 2. A-G: Schinus congestiflora. A. Flowering branchlet plus detail of the venation and margin on distal portion of leaf (inset); B. Staminate inflorescence; C. Staminate flower at anthesis with two petals and one sepal removed; D. Flowering branchlet plus detail of the venation and margin on distal portion of leaf (inset); E. Flowering branchlet; F. Fruiting branchlet; G. Pistillate flower at anthesis plus detail of the flower with two petals and one sepal removed. H-P: Schinus minutiflora. H. Flowering branchlet; I. Leaf plus detail of the venation and margin on distal portion (inset); J. Staminate inflorescence; K. Staminate flower with two petals and one sepal removed; L. Leaf plus detail of the venation and margin on distal portion (inset). M-N. Fruiting branchlet; O. Pistillate flower at anthesis plus detail of the flower with two petals and one sepal removed; P. Immature fruit in development. 
Nee 40702, fl. (MO, NY); valley along small stream (quebrada Yunga), along road from Mairana to Yunga de Mairana, $11.8 \mathrm{~km}$ (by road), $5 \mathrm{~km}$ (by air) NE from the

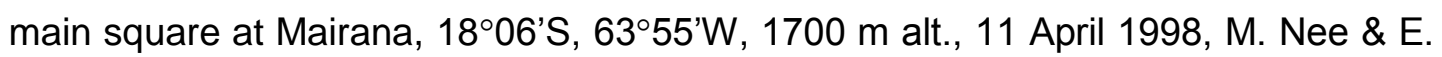
Chávez 48946, fl. (MO, NY); 6 km (by air) NE of Mairana, campamento La Yunga, 1805'40'S, 6355'W, 1950 m alt., 21 july 1994, M. Nee 45301, fl. (LPB, MO, NY); $3.2 \mathrm{~km} \mathrm{~N}$ of Campamento Yungas of Parque Nacional Amboró, $6.5 \mathrm{~km}$ (by air) NE

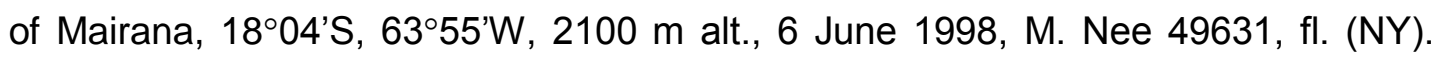
Manuel María Caballero, $6.5 \mathrm{~km}$ (by air) $\mathrm{N}$ of Comarapa, $17^{\circ} 51.6^{\prime} \mathrm{S}, 64^{\circ} 32.1^{\prime} \mathrm{W}$, $2380 \mathrm{~m}$ alt., 3 Aug 2003, M. Nee et al. 52432, fl. (MO, NY); along highway from Cochabamba to Comarapa, $5.5 \mathrm{~km}$ (by road) NW of Torrecillas, 1750'S, 64³8'30'W, 2600 m alt., 10 Jul 1998, M. Nee \& D. Atha 50015, fl. (NY); 4.5 km (by air) N of Comarapa, 1752'S, 6431'30’W, 2200 m alt., 27 Nov 1999, M. Nee 50716, fl. (NY, SI); Parque Nacional Amboro, Cerro Bravo, juntas del río Alizar y Amparo, 1757’S, 64²4'W, $2000 \mathrm{~m}$ alt., 7-15 June 1992, I.G. Vargas et al. 1508, fl. (LPB,

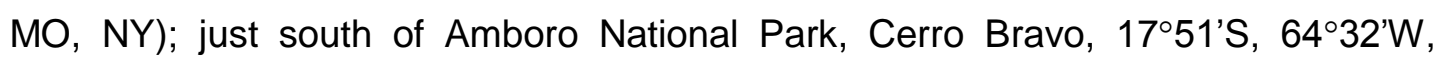
2300-3000 m alt., 20 Jun 1995, J. Abbott \& A. Jardim 17233, fl. (MO, NY, UZM); P.N. Amboro, Cerro Bravo, cerca Comarapa, 2600 m alt., 23 Jun 1995, A. Jardim \& R. Abbott 2108, fl., fr. (MO, NY, UZM); Parque Nacional Amboro, La Siberia, 25 km al NW sobre la carretera de Comarapa hacia Cochabamba, entrada al Astillero, 1709.5'S, 643․5'W, 2570 m alt., 9 May 1993, I.G. Vargas et al. 2389, fr. (LPB,

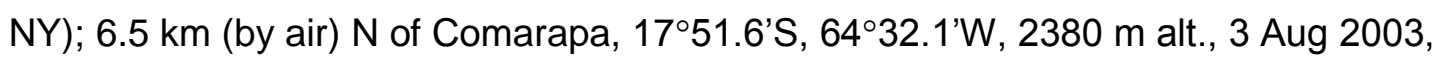
M. Nee et al. 52429, fl. (NY); rio camino a San Mateo, 1744'15'S, 6444'19”W, $1830 \mathrm{~m}$ alt., 10 April 2004, D. Soto et al. 156, fl. (BOLV, MO); comunidad La Laguna

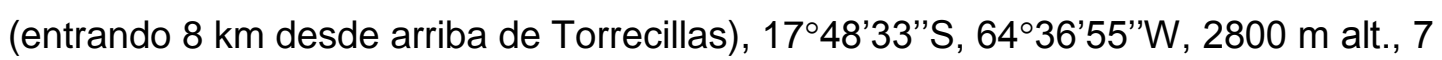
Nov 2003, I.G. Vargas 7046, fl. (MO, NY, USZ); Parque Nacional Amboro,

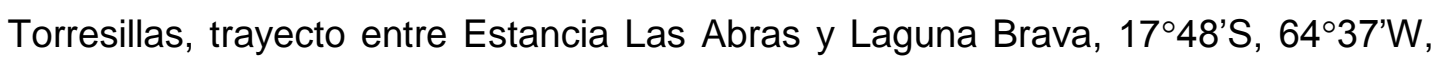
2500-3000 m alt., 8-9 May 1992, I.G. Vargas \& E. Prado 1305, fl. (MO, NY); 3 km SW of Laguna Brava, $5.7 \mathrm{~km}$ (by road) $\mathrm{N}$ of turnoff from the ComarapaCochabamba highway, 1749.1'S, 6437.5' W, 2725 m alt., 6 Aug 2003, M. Nee \& M. Mendoza 52504, fl. (MO, NY); Siberia, Larka Pampa, 1750'29”S, 6444’3”W, 2950 m alt., 20 Sept 2003, E. Fernández et al. 2498, fl. (BOLV, MO). Vallegrande: rota 22 de Guadalupe a Ipita, 18³9'56.8'’, 6355'29.4'W, 2297 m alt., 6 Jan 2014 , C.L. Silva-Luz \& L.F. Luz 234, fr. (NY, RB, SPF); about $10 \mathrm{~km} \mathrm{~S}$ of Vallegrande on the road to Pucará, 2250-2300 m alt., 22 April 1987, J. Brandbyge 730, fr. (LPB); Tacaso, ca. $18 \mathrm{~km}$ sur de Vallegrande, camino a Pucará, 18³6'S, 6406' $\mathrm{W}, 2300 \mathrm{~m}$ alt., 26 Feb 2002, L. Arroyo et al. 1839, fl. (MO, NY, USZ); Pueblo de Vallegrande, 
ca. 2 km N del Pueblo, 18²9.21'S, 6406.59'W, 2082 m alt., 19 Jan 2003, M. Mendoza \& E. Calzadilla 444, fl. (LPB, USZ); Huasacañada, $5 \mathrm{~km}$ al de la ciudad de Vallegrande, 18³1.5'S, 645.7’W, 2050 m alt., 3 Nov 1990, I.G. Vargas 817, fl. (MO, NY); Huasacañada, 18³1'54'S, 645'51'W, 2050 m alt., 10 Sept 1989, I.G. Vargas 310, fl. (NY, USZ); $6.5 \mathrm{~km}$ (by air) SW of Guadalupe on road to Pucara, at

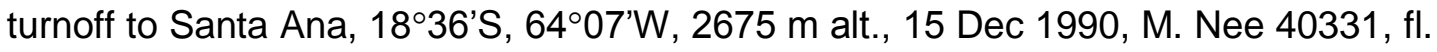
(MO, NY); Camino de Vallegrande, 12 a $15 \mathrm{~km}$ antes de la comunidad de Loma Larga, 1840’37'S, 6354'59'W, 2363 m alt., 24 Aug 2008, L. Arroyo et al. 3969, fr. (MO, NY, UZM).

Distribution. Endemic to Bolivia, occurring in Santa Cruz and Cochabamba departments, but also with some populations distributed in Vallegrande Department (Fig. 7D).

Ecology. Schinus congestiflora occurs in Tucumán-Bolivian forests and Yungas or in ecotones between montane cloud forests and pre-Puna, Puna or dry inter-Andean valleys (Fig. 7D), in relictual Prumnopitys and Podocarpus forests between 1700-3191 m. It is often distributed in shrubby disturbed areas with patches cleared for cultivation or pasture. It is known to flower Jan-Dec, and fruit Dec-Feb and Apr-Jun and Aug.

Conservation status. The IUCN threat status of $S$. congestiflora was evaluated as Near Threatened (NT) based on the extent of occurrence $\left(E O O=21,565.625 \mathrm{~km}^{2}\right)$ and as Endangered (EN) according to area of occupancy $\left(A O O=112.000 \mathrm{~km}^{2}\right)$. There are numerous collections of $S$. congestiflora, but mainly from sparse road network in Bolivia. Low collection densities in the montane cloud forests are probably due to the difficulty to access them or fieldwork gap. Also, populations are known within Amboró National Park. Because of this we assign a preliminary IUCN threat status of Near Threatened (NT).

Common name. Luyo-luyo (Spanish)

Discussion. Specimens of $S$. congestiflora are often identified as $S$. myrtifolia. Both taxa share staminate inflorescences of similar length $(0.5-1.3 \mathrm{~cm}$ long, 0.3-1.4 cm long, respectively), but the former species can be distinguished by the leaves that are broadly obovate, sometimes ovate or oblong (Fig. 2A,D,F, Fig. 4B-C; vs. broadly elliptic or oblong or rarely ovate in S. myrtifolia - Fig. 5F,I,J,L), secondary veins slightly impressed or flat on the adaxial surface (vs. impressed or flat medially and impressed toward margin on the adaxial surface), costal veins in 68 pairs (vs. 8-16 pairs), tertiary veins inconspicuous (vs. often conspicuous), staminate inflorescences in congested pseudoracemes, often branched at base and 
densely branched distally (Fig. 4B; vs. unbranched staminate pseudoracemes - Fig. 5F, 6E) and pistillate inflorescences with $0.5-1 \mathrm{~mm}$ long median internodes (vs. 2$3.5 \mathrm{~mm}$ long). Specimens of $S$. congestiflora sometimes have leaves that are smaller (ca. 0.7-0.9 cm) and orbicular (Fig. 2E) and so could resemble $S$. subtridentata. When these species occur sympatrically (i.e., Cochabamba Department), $S$. congestiflora can be recognized by its unarmed branches (Fig. 4A,C - vs. inconspicuously armed branches - Fig. 8I,N in S. subtridentata), leaves chartaceous (vs. coriaceous), staminate flowers with pedicels 1.3-2.5 mm long (vs. 1.4-1.6 $\mathrm{mm}$ long), and by the pistillate inflorescences with $0.5-1 \mathrm{~mm}$ long median internodes (vs. $1-1.5 \mathrm{~mm}$ long). When populations of $S$. congestiflora and $S$. minutiflora occur sympatrically (e.g. Santa Cruz Department), it can be difficult to separate them because the first species sometimes has ovate leaves (Fig. 2F, 4C) as in S. minutiflora (Fig. $2 \mathrm{H}, \mathrm{I}, \mathrm{N}$ ), and pistillate inflorescences with similar length (3$14 \mathrm{~mm}$ in $S$. congestiflora and $5-9 \mathrm{~mm}$ in $S$. minutiflora), but in the former species the pistil is $0.7-0.8 \mathrm{~mm}$ long and in the latter it is $0.9-1.1 \mathrm{~mm}$ long. Schinus congestiflora may also co-occur in sympatry with S. pilifera I.M. Johnst., S. pearcei Engl. and $S$. areira $L$. (these species not treated in this taxonomic revision), in ecotones between montane cloud forests and arid vegetations, such as dry interAndean valleys, pre-Puna, Puna, or Chacoan areas of Santa Cruz and Cochabamba departments. Schinus pilifera differs from $S$. congestiflora by having armed branches, S. pearcei has dissected leaves, and $S$. areira by having compound leaves (vs. unarmed branches and simple leaves in S. congestiflora).

2. Schinus gracilipes I.M. Johnst., Journal of the Arnold Arboretum 19(3): 257. 1938. - Type: Argentina, Tucumán, Trancas, Tapia, 750 m alt., 29 Aug 1925, S. Venturi 3887 (holotype: GH!; isotypes: LIL [photo]!, MO!, US!).

Figures 3A-G, 7A

= Schinus gracilipes var. pilosa F.A. Barkley, Brittonia 5(2): 180. 1944. - Type: Argentina, Tucumán province, Trancas, 1700 m alt., 19 Apr 1926, S. Venturi 4173 (holotype: US!; isotypes: LIL [photo]!).

Description. Tree(lets), sometimes shrubs, 2-10 m tall. Branches prostrate, unarmed, glabrous, sparsely pilose, puberulous or clavate-glandular, sometimes densely villous. Trichomes simple, barbellate or bulbous and transparent, ferrugineous or cream-colored, or clavate-glandular and transparent, yellow or orangish-red; erect or appressed, straight, sigmoid or nutant, $0.03-0.5 \mathrm{~mm}$ long on branches, leaves and inflorescences. Leaves not congested; petiole 5-12 mm long, 
canaliculate or semi-terete, on abaxial surface glabrous, on adaxial surface puberulous, strigose or clavate-glandular, sometimes tomentose or villous; blade 2.5-5.8 x 1.4-2.5 cm, ovate or ovate-lanceolate; apex obtuse, sometimes acute, rounded or straight; medially subsymmetrical or asymmetrical, basal insetion symmetrical or asymmetrical, base width (sub)symmetrical, obtuse, cuneate or decurrent, sometimes rounded or truncate; margin crenate, crenate-serrate, twiceserrate or erose, (slightly) revolute on proximal portion, undulate, sometimes villous, tomentose or strigose; texture membranaceous or chartaceous, dull; costal secondaries in 7-16 pairs, spacing irregular, course straight or arcuate, angle irregular, uniform or smoothly increasing toward base; marginal secondary vein 0.08-0.2 mm in width, conspicuous; tertiary veins often visible; on abaxial side the midvein prominent, prominulous or flat, secondary veins flat, tertiary veins flat, sparsely pilose, strigose, puberulous or clavate-glandular, sometimes villous, tomentose, or strigose on midvein; on adaxial side the midvein prominulous proximally and flat distally, secondary veins flat or prominulous medially and impressed toward margin and apex, tertiary veins impressed, sparsely pilose, strigose, puberulous or clavate-glandular, sometimes conspicuous villous, tomentose or strigose on midvein. Inflorescences axillary or terminal, puberulous, pilose or clavate-glandular, sometimes densely villous; bracts dimorphic, smaller ones 0.4-1 x 0.4-1 mm, ovate, lanceolate or deltate, larger ones 2.1-3.4 x 1.1-1.7 $\mathrm{mm}$, obovate, foliose; bracteoles 0.4-0.8 $\times$ 0.2-0.5 mm, ovate; bracts and bracteoles pilose, puberulous or clavate-glandular, sometimes densely villous on both surfaces; pedicel hirsute, pilose or clavate-glandular, sometimes villous, bracteoles subtending pedicel; sepals pilose, puberulous or clavate-glandular, sometimes densely villous on both surfaces, conspicuous on margin; petals with midvein and 1 cladodromous secondary vein, sometimes not visible, densely ciliate, sometimes sparsely villous or puberulous on margin; disk $0.3-0.5 \mathrm{~mm}$ tall and ca. $0.06-0.2 \mathrm{~mm}$ thick, glabrous. Staminate inflorescences $10-45 \mathrm{~mm}$ long, flowers in thyrsoids or panicles, sometimes pseudoracemes, median internodes $2.5-5 \mathrm{~mm}$ long. Staminate flowers with pedicel 2-6 mm long overall, portion distal to articulation 1.1-3.1 mm long; sepals 0.4-1.1- x 0.4-0.9 mm, ovate or oblong; petals $1.4-2 \times 0.8-1.2 \mathrm{~mm}$, ovate or obovate, slightly concave; antesepalous and antepetalous stamens 0.7-1 and 0.6-0.8 mm long, respectively; anthers 0.2-0.4 mm long, ovate or oblong in dorsiventral view, oblong in lateral view; pistillode $0.3-0.5 \mathrm{~mm}$ long. Pistillate inflorescences $6-10 \mathrm{~mm}$ long, flowers in thyrsoids or pseudoracemes, median internodes 0.5-1.7 mm long. Pistillate flowers with pedicel 2-3.5 $\mathrm{mm}$ long overall, portion distal to articulation 0.9-2.5 mm long; sepals $0.6-0.9 \times 0.5-0.9 \mathrm{~mm}$, ovate; 
petals 1-1.7 x 0.7-1 mm, ovate or oblong, concave; pistil 0.8-1.2 mm long overall, glabrous; ovary globose, style $0.1(-0.4) \mathrm{mm}$ long; antesepalous and antepetalous staminodes 0.3-0.5 mm long and 0.3-0.4 mm long, respectively, anthers 0.2-0.3 $\mathrm{mm}$. Fruiting pedicel $3.5-7 \mathrm{~mm}$ long overall, portion distal to articulation 1.7-2.1 $\mathrm{mm}$ long, puberulous or clavate-glandular. Drupes 6-7.7 x 4.6-5.3 mm, red, obliquely ovoid, laterally compressed, glabrous or sparsely clavate-glandular, sometimes glabrescent.

Specimens examined. Argentina. Catamarca: Sierra de Ambato (Falda E.), subiendo desde El Rodeo hacia el cerro Manchado, 2700-2900 m alt., 23/25 Feb 1967, A.T. Hunziker 19161, fl. (CORD, NY, SI); Sierra Ambato (Falda O), alrededores de Las Casitas, frente a El Rincón, 2500 m alt., 20 Feb 1970, A.T. Hunziker \& L Ariza 20419, sterile (MBM, NY). Jujuy: Santa Bárbara, Santa Cornelia, 1 March 1911, C.L. Spegazzini 1362 (LP). Salta: quebrada San Lorenzo, Nov 1919, L. Hauman, fl. (BA 27535); Guachipas, Cuesta del Lajar, ruta 9, $23 \mathrm{~km}$ al SE de Guachipas, 1900-2000 m alt., 16 Jan 1990, L.J. Novara \& S. Bruno 9393 (MCNS); Sierra de La Candelaria, 1700 m alt., 23 Sept 1929, S. Venturi 9571, fl., fr. (GH, MO, NY); Guachipas, Cuesta del Lajar, 1850-1900 m alt., 27 Oct 1991, A. Charpin 23077, fl. (G, NY). Tucumán: Trancas, 1700 m alt., 19 Apr 1926, S. Venturi 4173, fl. (US [holotype S. gracilipes var. pilose]); proximidades Laguna del Tesoro, 2000 m alt., 6 Nov 1966, A.A. Vaca 267, fl. (ICN, LIL); camino desde Tafí del Valle hacia Las Carreras, a 2 km de Tafí del Valle, Cerro El Pelado, $26^{\circ} 51^{\prime} \mathrm{S}, 65^{\circ} 34^{\prime} \mathrm{W}$, 2130 m alt., 9 Feb 2002, A.M. Cialdella et al. 67, fr. (SI); Garabatal, 30 Nov 1944, D. Olea 30, fl. (LIL, ICN, NY); Sala Ancajulio, 15 Dec 1944, D. Olea 110, fl., fr. (GH, LIL, NY); Tafí del Valle, Garabatal, 1600 m, 25 Oct 1930, R. Schreiter 6547, fl., fr. (GH, LIL, NY); Tafí del Valle, 2000 m alt., 11 Nov 1929, S. Venturi 10260, fl. (LIL, MO, NY); Chigligasta, camino dique Pueblo Viejo, 13 Jan 1965, P.R. Legname \& A.R. Cuezzo 4194, fr. (LIL, NY); río Cochuna, 1000 m alt., 3 Nov 1930, R. Schreiter 6461, fl. (LIL, NY); Siambón, quebrada de Matadero, 1200 m alt., 8 Dec 1888, M. Lillo 1163, fl. (LIL, NY); Anfama, 24 Jan 1935, Castellanos, fl. (BA 19200); Tafí del Valle, 17 Sept 1997, M. Dematteis \& G. Seijo 751, fl. (CTES, MBM); Trancas, Tapia, $750 \mathrm{~m}$ alt., 29 Aug 1925, S. Venturi 3887, fl., fr. (GH [holotype], MO, US [isotypes]);

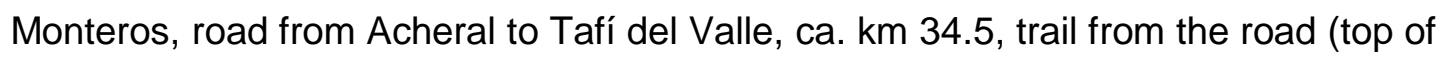
ridge) to the river, 2 Jan 1988, J.S. Bricker et al. 182, fr. (MO, NY); cuesta del Hualincho, 2500 m alt., 10 April 1904, Rodriguez 29, fl. (GH, LIL, NY); Burruyacu, Cerro de Medina, $1200 \mathrm{~m}$ alt., 1 March 1914, Moretti 2038, sterile (LIL, NY); quebrada de La Hoyada a la Cuesta de Los Bravos, 1600 m alt., 30 Sept 1924, R. Schreiter 3312, fl. (LIL, NY); cumbre Sierra San Javier, 1300 m alt., 24 Oct 1897, M. 
Lillo 2060, fl. (LIL, NY); Tafí del Valle, 2000 m alt., 9 Feb 1907, M. Lillo 5710, fr. (LIL, NY).

Distribution. Endemic to northwest Argentina, distributed in Catamarca, Jujuy, Tucumán and Salta provinces, with dense populations concentrated in the last two provinces (Fig. 7A).

Ecology. Plants of Schinus gracilipes are tree(lets) or sometimes shrubs, often prostrate or supported by nearby trees, occurring on slopes and mountains of the Tucumán-Bolivian Forests (Fig. 7A) associated with Alnus, Podocarpus and Polylepis forests, between 750-2900 m. According to Muñoz (2000), S. gracilipes is also distributed in Chacoan areas. It has been collected in flower in Aug-Dec, Feb and April, and in fruit in Aug-Feb.

Conservation status. The IUCN threat status of $S$. gracilipes was evaluated as Near Threatened (NT) based on the extent of occurrence (EOO=29,110.173 $\mathrm{km}^{2}$ ) and as Endangered (EN) according to area of occupancy $\left(A O O=64.000 \mathrm{~km}^{2}\right)$. We assign a preliminary IUCN threat status of Near Threatened (NT) based on the extent of occurrence which seems to encompasse suitable habitat for this species. Also, the low number of collections in potential areas of occurrence could be related to fieldwork gap, since in nearby areas with similar vegetation they are numerous, suggesting that $S$. gracilipes is a common species. Besides, populations are known nearby the Campo de los Alisos National Park.

Common names. Molle, molle trepador, molle del cerro, molle de la quebrada, horco molle, horcomolle, molle blanco, blanquillo (Spanish)

Discussion. Barkley (1944) described S. gracilipes var. pilosa F.A. Barkley based on specimens whose branches, leaves and inflorescences are densely villous (Fig. 3G). The morphological analysis evidenced that S. gracilipes has several types of indumentum (i.e., pilose, strigose, puberulous, villous, tomentose, strigose or clavate-glandular), and individuals have an intermediated degree of density, which makes difficult the identification of variety. Thus, like Muñoz (2000) we consider these plants to be part of the morphological variation of $S$. gracilipes. This species is easily recognized because its leaf margin is consistently crenate, crenate-serrate, twice-serrate or erose (Fig. 3A,B,D), instead of only on distal portion as often seen in other species. Schinus gracilipes sometimes has pistillate inflorescences that are usually pseudoracemes but sometimes thyrsoids, and puberulous petals on margin (Fig. 3C,E,F). Both characters are uncommon in other species of S. sect. Myrtifolia. Schinus gracilipes may occur in sympatry with S. myrtifolia in Salta and Jujuy provinces, but the former species differs by characteristics of leaf margin and inflorescences mentioned before, whereas the latter species has leaves with the 
margin entire, sometimes entire on proximal portion and slightly crenate on distal portion (Fig. 5F,I,J,L, Fig. 6F,G), unbranched pseudoracemes (Fig. 5F, 6E), and petals essentially glabrous or rarely puberulous or clavate-glandular on both surfaces (Fig. 5G,H,K). Schinus gracilipes may also co-occur with $S$. pilifera, $S$. bumelioides I.M. Johnst. and $S$. areira (these species not treated in this taxonomic revision) in ecotones between montane cloud forests and arid areas such as prePuna, Puna, dry inter-Andean valleys, or Chaco. Schinus pilifera and S. bumelioides differ from $S$. gracilipes by having armed branches, and $S$. areira has compound leaves (vs. unarmed branches and simple leaves in S. gracilipes).

3. Schinus meyeri F.A. Barkley, Lilloa 33(14): 295. 1973. - Type: Argentina, Salta, Santa Victoria, Los Toldos, Huaico Chico, $1700 \mathrm{~m}$ alt., 19 Aug 1971, F. Vervoorst \& P.R. Legname 4494 (holotype: LIL [photo]!).

Figures: $3 \mathrm{H}-\mathrm{L}, 7 \mathrm{~A}$

Description. Tree(lets), sometimes shrubs, 3-8 $\mathrm{m}$ tall. Branches prostrate, unarmed, glabrous, puberulous or clavate-glandular, rarely hirsute. Trichomes simple, sometimes barbellate and transparent or cream-colored or clavate-glandular and transparent or orangish-red; erect or appressed, straight or sigmoid, 0.03-0.1 $\mathrm{mm}$ long on branches, leaves and inflorescences. Leaves not congested; petiole 7$17 \mathrm{~mm}$ long, (deeply) canaliculate, glabrous, puberulous or clavate-glandular, rarely hirsute on both surfaces; blade 4.2-8.8 x 2.5-4.5 cm, ovate or ovate-lanceolate; apex acute, rarely obtuse, often straight, sometimes rounded; medially (sub)symmetrical, basal insertion (sub)symmetrical, basal width (sub)symmetrical or asymmetrical, obtuse, cuneate or decurrent, sometimes rounded; margin often entire, sometimes entire on proximal portion and crenate or erose on distal portion, slightly revolute on proximal portion, puberulous or strigose, sometimes pilose on proximal portion; texture often membranaceous, sometimes chartaceous, dull; costal secondaries in 14-24 pairs, spacing irregular, course arcuate, angle irregular; marginal secondary vein $0.04-0.1 \mathrm{~mm}$ in width, inconspicuous; tertiary veins visible; on abaxial side the midvein prominent proximally and prominulous distally, secondary veins consistently flat, or prominulous or flat medially and impressed toward margin, tertiary veins flat, clavate-glandular, rarely hirsute or pilose; on adaxial side the midvein prominulous proximally and flat distally, secondary veins flat or prominulous, sometimes flat medially and impressed toward margin, tertiary veins impressed, puberulous, rarely hirsute on veins. Inflorescences axillary or terminal, puberulous, pilose or clavate-glandular; bracts dimorphic, smaller ones 
0.5-1 x 0.7-1 mm, deltate or (broadly) ovate, larger ones $1.7-2.3 \times 0.8-1.5 \mathrm{~mm}$, oblong or lanceolate, foliose, involute; bracteoles 0.3-0.4 x 0.2-0.3 mm, ovate; bracts and bracteoles pilose, puberulous or clavate-glandular on both surfaces; pedicel puberulous or clavate-glandular, sometimes bracteoles present on the pedicel; sepals glabrous, puberulous or clavate-glandular on both surfaces, sometimes conspicuous on margin; petals with midvein branching from median portion toward apex and 1-2 cladrodomous secondary veins, glabrous on both surfaces, puberulous on margin; disk $0.5 \mathrm{~mm}$ tall and ca. $0.1 \mathrm{~mm}$ thick, glabrous. Staminate inflorescences $15-55 \mathrm{~mm}$ long, flowers in lax pseudoracemes, often branched at base, sometimes thyrsoids, cymes or solitary, median internodes 2.1-5 $\mathrm{mm}$ long. Staminate flowers with pedicel (2.5-) 3.5-8 mm long, the articulation not visible; sepals (0.6-) 0.8-1.2 x 1-1.2 mm, (broadly) ovate; petals 1.7-2.2 x 1.3 mm, (broadly) oblong or ovate, concave; antesepalous and antepetalous stamens 1-1.3 and 0.7-1 mm long, respectively; anthers 0.3-0.4 mm long, ovate in dorsiventral and lateral views; pistillode 0.3-0.5 mm long. Pistillate inflorescences $15-25 \mathrm{~mm}$ long, flowers in pseudoracemes, median internodes 3-7.4 mm long. Pistillate flowers with pedicel 3.5-7.5 mm long overall, the articulation not visible; sepals $1.3 \times 1-1.4 \mathrm{~mm}$, (broadly) ovate; petals $1.5-1.8 \times 1-1.1 \mathrm{~mm}$, ovate, slightly concave; pistil $1.4 \mathrm{~mm}$ long overall, glabrous; ovary globose, laterally compressed; antesepalous and antepetalous staminodes $0.6-0.7 \mathrm{~mm}$ long and 0.5-0.4 mm long, respectively, anthers $0.3 \mathrm{~mm}$ long. Fruiting pedicel $4-13 \mathrm{~mm}$ long overall, the articulation not visible, puberulous or clavate-glandular, sometimes bracteoles along the pedicel. Drupes 6.6 × $6.5 \mathrm{~mm}$, pink, obliquely ovoid, laterally compressed, glabrous or sparsely clavate-glandular.

Specimens examined. ARGENTINA. Salta: Santa Victoria, aprox. $5 \mathrm{~km}$ de Los Toldos, camino a Lipeo, 5 Dec 2005, M.M. Arbo et al. 9084, fl. (CTES, MBM); camino de Los Toldos a Lipeo, a $12 \mathrm{~km}$ de Los Toldos, $1800 \mathrm{~m}$ alt., 5 Oct 1973, P.R. Legname \& A.R. Cuezzo 9757C, fl. (LIL, NY); 1 km de Los Toldos, camino a Finca Los Nogales, orillas del Arroyo Huaico Grande, 20 Nov 2001, O. Morrone et al. 3824, fl. (MO, SI); 3 km de Los Toldos a Lipeo, 1600 m alt., 9 Nov 1975, M.M. Schiavone et al. 11707C, fl. (LIL, MO); camino del Lipeo a Los Toldos, ca. $10 \mathrm{~km}$ de Los Toldos, 8 Nov 1975, M.M Schiavone et al. 11883C, fl. (LIL, NY); Los Toldos, Cerros al E del Pueblo, margen S del rio Toldos, 1700-1900 m alt., 2 Nov 1989, L.J. Novara et al. 9100, fl. (SI); Los Toldos, Huaico Chico, 1700 m alt., 19 Aug 1971, F. Vervoorst \& P.R. Legname 4494, fl. (LIL [holotype]). BOLIVIA. Tarija: Aniceto Arce, El Sunchal, 2000 m alt. 9 Feb 2006, S. Gallegos et al. 305, fr. (LPB, NY); Tarija, 76 km hacia Bermejo, passando Padcaya, 1960 m alt., 20 Oct 1983, S.G. Beck \& M. 
Liberman 9616, fl., fr. (LPB, NY). Burnet O’Connor, $27 \mathrm{~km}$ hacia Entre Ríos, $2200 \mathrm{~m}$ alt., 22 Oct 1983, S.G. Beck \& M. Liberman 9656, fl. (LPB, MO, NY, SI, USZ). Cercado, Pampa Redonda, 2143'11'S, 6451'03'W, 2045 m alt., 8 Feb 2006, F. Zenteno et al. 3593, fr. (LPB, NY).

Distribution. Restricted species to south Bolivia, in Tarija Department and northwest Argentina, in Santa Victoria Department (Fig. 7A).

Ecology. Schinus meyeri occurs in Tucumán-Bolivian forest and ecotone between montane cloud forests and pre-Puna, Puna or dry inter-Andean valleys (Fig. 7A), associated with Podocarpus and Alnus forests (Muñoz 2000), between 1600-2100 m alt. It is known to flower in Aug and Oct-Dec, and fruit in Feb and Oct.

Conservation status. We assign a preliminary IUCN threat status as Endangered (EN, A4) based both on extent of occurrence (EOO=3,033.395 $\mathrm{km}^{2}$ ) and area of occupancy $\left(\mathrm{AOO}=24.000 \mathrm{~km}^{2}\right)$. The low collection densities of $S$. meyeri could be related to fieldwork gap, since this species occurs within or nearby the Tariquía Flora and Fauna National Reserve, a relatively large protected area in Bolivia.

Common name. Not reported

Discussion. Schinus meyeri and $S$. venturii have similar distributions and morphological characteristics. Barkley (1973) differentiated S. meyeri from $S$. venturii based on the size of the plant, leaf margin and lobing of the flower disk. Although detailed morphological analysis showed overlapping in the features chosen by Barkley. Schinus meyeri can be distinguished from $S$. venturi by its petiole deeply canaliculate (vs. semi-terete or sometimes slightly canaliculate), leaves often membranous (vs. chartaceous), tertiary veins conspicuous (Fig. 3H; vs. inconspicuous - Fig. 3M,N), the staminate inflorescences in lax pseudoracemes or solitary flowers (Fig. 3I; vs. staminate pseudoracemes congested - Fig. 3N), and petals with the midvein often branching from median portion toward distal portion (vs. midvein sometimes branching at apex). Schinus meyeri may co-occur also in Tucumán-Bolivian forests of Bolivia with $S$. obliqua, but the former species differs because its leaves are clavate-glandular on the abaxial surface, clavate-glandular or puberulous on the veins of the adaxial surface, puberulous or strigose on the margin (especially on proximal portion), whereas the latter species has leaves clavateglandular, hirsute or villous on both surfaces, densely so on the veins (Fig. 9A,D,E). Schinus meyeri and S. myrtifolia may have overlapping distributions in TucumánBolivian forests of Salta in Argentina, but $S$. meyeri can be distinguished by the leaves ovate, ovate-lanceolate or lanceolate, the base obtuse (Fig. $3 \mathrm{H}, \mathrm{I}, \mathrm{K})$, the staminate and pistillate inflorescences with median internodes 2.1-5 mm and 3-7.4 
$\mathrm{mm}$, respectively. Schinus myrtifolia has leaves broadly elliptic or oblong, rarely ovate, the base acute, rarely obtuse (Fig. $5 \mathrm{~F}, \mathrm{I}, \mathrm{J}, \mathrm{L}$ ), and the staminate and pistillate inflorescences with median internodes with 0.8-1.8 mm and 2-3.5 mm, respectively. Schinus meyeri may also occur sympatrically with populations of $S$. pilifera, $S$. bumelioides and $S$. areira (these species are not treated in this taxonomic revision), in ecotones between montane cloud forests and pre-Puna, Puna dry inter-Andean valleys, or Chaco. Schinus pilifera and S. bumelioides differ from S. meyeri because of their armed branches, $S$. areira additionally by having compound leaves (vs. unarmed branches and simple leaves in $S$. meyeri).

4. Schinus microphylla I.M. Johnst., Journal of the Arnold Arboretum 19(3): 258. 1938. - Type: Peru: Apurimac, above Argama, on trail to Andahuylas 3800 m alt., 5.XI.1935, J. West 3747 (holotype: GH!; isotype: UC).

Figures: 4 D-E, 5 A-E, 7 C

= Schinus dependens Ortega var. parviflora Marchand, Révision du groupe des Anacardiacées 164. 1869, syn. nov. इ Duvaua dependens (Ortega) DC. var. parviflora (Marchand) Arechaval., Anales del Museo de Historia Natural de Montevideo 3: 301. 1900, syn. nov. इ Schinus polygama (Cav.) Cabrera fo. parviflora (Marchand) Cabrera, Revista del Museo de La Plata, Sección Botánica 2: 34. 1938, syn. nov. E Schinus polygama (Cav.) Cabrera var. parviflora (Marchand) F.A. Barkley, Brittonia 5(2): 176. 1944, syn. nov. Type: Bolivia, 1839, J.B. Pentland 18 (P [photo]!).

= Schinus dependens Ortega var. crenata Engl., in Mart., Flora brasiliensis 12(2): 388. 1876, syn. nov. इ Duvaua dependens (Ortega) DC. var. crenata (Engl.) Arechaval., Anales del Museo Nacional Montevideo 3: 300. 1900, syn. nov. ESchinus dependens Ortega var. andina Engl., in DC., Monographiae Phanerogamarum 4: 341. 1883, nom. illeg. E Schinus andina (Engl.) I.M. Johnst., Journal of the Arnold Arboretum 19(3): 259. 1938, nom. illeg. इ Schinus microphylla I.M. Johnst. var. andina (Engl.) J.F.Macbr., Publications of the Field Museum of Natural History, Botanical Series 13(3A/1): 252. 1951, nom. illeg. - Lectotype (designated here): Bolivia, Prov. Larecaja, vicinius Sorata, 2650-2800 m alt., Aug-Jan 1858, Mandon, G. 768 (BM [photo]!; isolectotypes: G [photo]!, GH!, K [photo]!, NY!, P [photo]!, S [photo]!, US!). 
Description. Tree(lets) or shrubs, 1-3 m tall. Branches erect, often conspicuously armed, sparsely strigose, puberulous or densely clavate-glandular. Trichomes simple and transparent or clavate-glandular and transparent or orangishred; erect or appressed, straight, arcuate or slightly sigmoid, 0.03-0.08 mm long on branches, leaves and inflorescences. Leaves often congested; petiole 1.5-3.5 mm long, semi-terete, sometimes (slightly) canaliculate, puberulous or clavate-glandular on both surfaces; blade $0.9-2 \times 0.6-1 \mathrm{~cm}$, essentially obovate, sometimes oblong or ovate; apex obtuse, rounded; medially subsymmetrical or asymmetrical, basal insertion (sub)symmetrical, base width (sub)symmetrical, base acute or obtuse, cuneate, decurrent or rounded; margin entire or entire on proximal portion and erose or crenate on distal portion, sometimes slightly lobed on distal portion, slightly revolute, strigose; chartaceous or coriaceous, often glossy; costal secondaries in 46 pairs, spacing irregular, course straight or arcuate, angle smoothly decreasing toward base; marginal secondary vein $0.1 \mathrm{~mm}$ in width, inconspicuous; tertiary veins not visible; on abaxial side the midvein prominent proximally and prominulous or impressed distally, secondary veins prominulous, flat or impressed, clavateglandular or sparsely strigose; on adaxial side the midvein prominent proximally and prominulous distally, secondary veins prominulous or impressed, densely clavateglandular on midvein, rest of surface clavate-glandular or sparsely strigose. Inflorescences axillary or terminal, pilose, puberulous or clavate-glandular; bracts dimorphic, smaller ones 0.2-0.7 x 0.4-0.8 mm, (broadly) ovate or deltate, larger ones 3.5-3.7 x 2-2.5 mm, obovate, foliose; bracteoles 0.1-0.3 × 0.1-0.2 mm, ovate; bracts and bracteoles puberulous, pilose or clavate-glandular on both surfaces; pedicel hirsute or clavate-glandular, bracteoles subtending pedicel; sepals hirsute or clavate-glandular, conspicuous on margin; petals with midvein and 2-3 cladodromous secondary veins, minutely puberulous or strigose on both surfaces. Staminate inflorescences 8-11 $\mathrm{mm}$ long, flowers in lax pseudoracemes, often branched at base and densely branched distally, median internodes 1.7-3.5 mm; disk 0.3-0.5 mm tall, 0.08-0.2 mm thick, glabrous. Staminate flowers with pedicel 1.5-3 mm long overall, portion distal to articulation 0.6-0.8 mm long; sepals 0.4-0.8 $\mathrm{x}$ 0.5-1 mm, (broadly) ovate or deltate; petals 1.6-2.1 x 1.3-1.5 mm, ovate or oblong, convex; antesepalous and antepetalous stamens 0.9-1.5 and 0.6-1 mm long, respectively; anthers $0.4-0.5 \mathrm{~mm}$ long, (broadly) oblong or ovate in dorsiventral view, oblong in lateral view; pistillode 0.4-0.5 mm long. Pistillate inflorescences 3-8 $\mathrm{mm}$ long, flowers in lax pseudoracemes, median internodes $1.7-2 \mathrm{~mm}$. Pistillate flowers with pedicel 2-3.3 mm long overall, portion distal to articulation 1.1-1.2 mm long; sepals 0.3-0.6 x 0.5-0.8 mm, (broadly) ovate or deltate; petals 1.3-2 × 1.4-1.5 

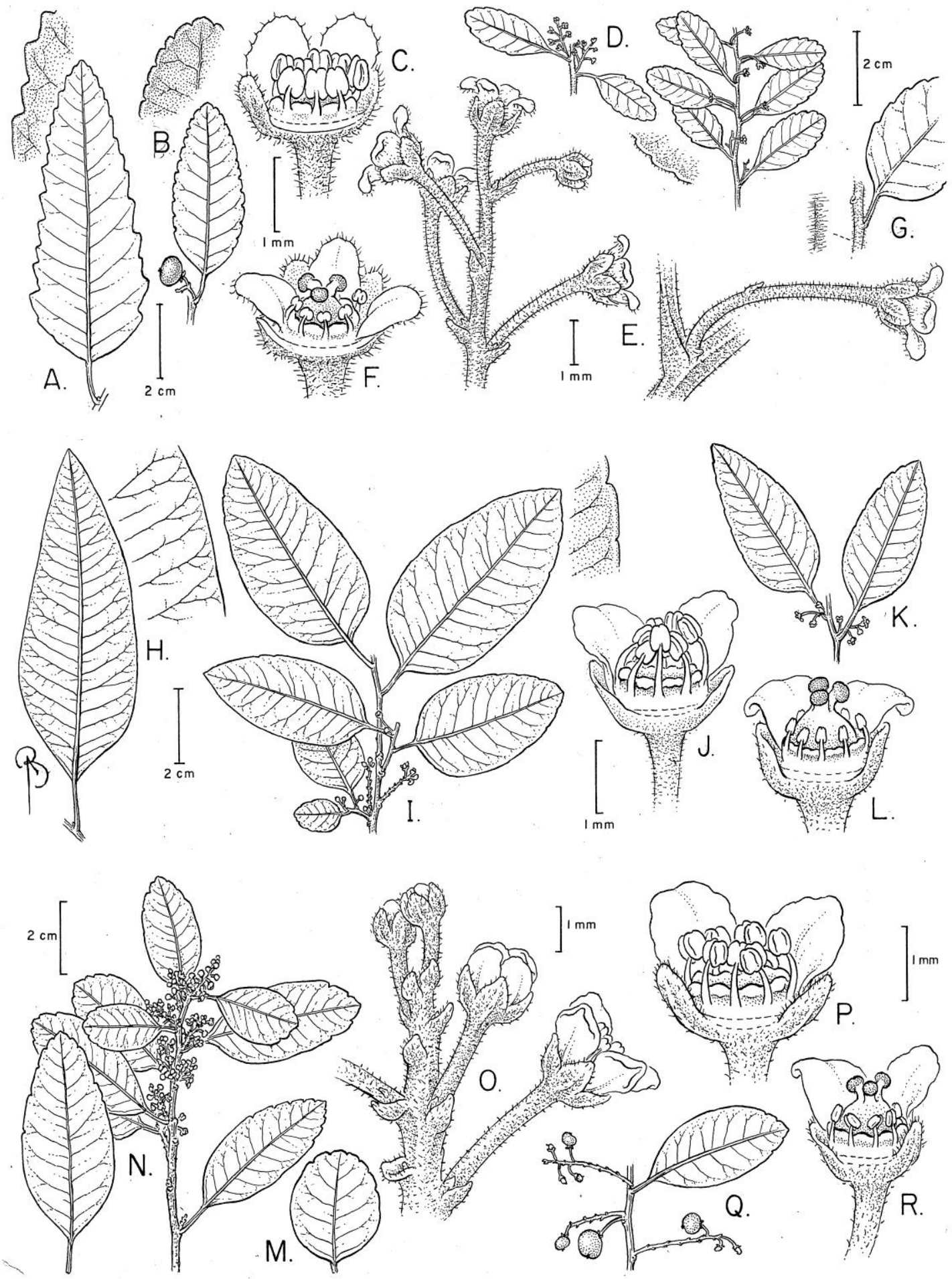

Fig. 3. A-G: Schinus gracilipes. A. Leaf plus detail of the margin, and secondary and tertiary veins (inset); B. Fruiting branchlet plus detail of the margin, and secondary and tertiary; C. Staminate flower with two petals and one sepal removed; D. Flowering branchlet plus detail of the indumentum and margin on leaf (inset); E. Inflorescence plus detail of the flower insertion, bract and bracteoles; $\mathbf{F}$. Pistillate flower; G. Branchlet plus detail of the indumentum (inset). H-L: Schinus meyeri. H. Leaf plus detail of the secondary and tertiary veins (inset); I. Flowering branchlet plus detail of the venation and margin on leaf (inset); J. Staminate flower with two petals and one sepal removed; K. Flowering branchlets; L. Pistillate flower with two petals and one sepal removed. M-R: Schinus venturii. M. Leaf; N. Flowering branchlet; O. Staminate inflorescence; P. Staminate flower with two petals and one sepal removed; $\mathbf{Q}$. Fruiting branchlet; $\mathbf{R}$. Pistillate flower with two petals and one sepal removed. 
$\mathrm{mm}$, obovate or oblong, slightly convex or concave; pistil 1-1.3 mm long overall, glabrous; ovary globose, laterally compressed, style $0.09 \mathrm{~mm}$ long or the style not visible, glabrous stigmas; staminodes the antesepalous and antepetalous ones 0.6$0.9 \mathrm{~mm}$ long and 0.5-0.7 mm long, respectively, anthers $0.2-0.3 \mathrm{~mm}$ long. Fruiting pedicel 1.5-1.8 mm long overall, portion distal to articulation $0.9-1 \mathrm{~mm}$ long, clavateglandular or puberulous. Drupes 4-4.3 x 5-6 mm, red, globose, glabrous, minutely strigose, hirsute or clavate-glandular.

Specimens examined. BOLIVIA. La Paz: La Paz, subida al cerro Muela del Diablo, $3650 \mathrm{~m}$ alt., 4 March 1979, S.G. Beck 1370, fl. (LPB, NY); Cota Cota, terreno de la UMSA, 3400 m alt., 15 Aug 1979, S.G. Beck 2335, fl. (LPB, NY); Calacoto, al sud del rio Huañajahuira, 3600 m alt., 4 Nov 1979, S.G. Beck 2363, fl. (LPB, NY); Eliodoro Camacho, Cantón Ambana, Ambana, $3500 \mathrm{~m}$ alt., 20 Dec 1980, S.G. Beck 4228, fl. (LPB, NY). Charazani, $3230 \mathrm{~m}$ alt., en los declives de las calles del Pueblo de Charazani, 4 Aug 1985, S.G. Beck 11368, sterile (LPB, NY). SE de La Paz, entre Ventilla y Palca, 3400 m alt., 13 Oct 1985, S.G. Beck 11658, fl. (HBG, F, LPB, NY, USZ); Pedro Domingo Murillo, ca. $15 \mathrm{~km}$ al este de La Paz, de Palca subiendo el río Choquekkota via Taquesi, 3650 arriba de Huancapampa, 22 Nov 1987, S.G. Beck 14337, fl., fr. (CUZ, K, LPB, NY, SI); La Paz, Universidad Mayor de San Andrés, jardim botânico do campus da faculdade de Ciencias Puras, 15 Jan 2014,C.L. Silva-Luz \& L.F. Luz 255, fl. (NY, RB, SPF); near La Paz, 10,000 ft., April 1885, H.H. Rusby 1446, fl. (NY); Hills on South side at Calacoto, 13³2’S, 6805’W, 3300-3600 m alt., 20 Jan 1982, J.C. Solomon 6747, fl. (MO, NY); ca. 80 kms. NNE de La Paz, via camino directo a Sapahaqui, $3500 \mathrm{~m}$ alt., 27 June 1983, S.G. Beck 8462, fr. (LPB, MO, NY); Larecaja, vicinius Sorata, 2650-2800 m alt., Aug-Jan 1858, G. Mandon 768 (BM [lectotype], G, GH, K, NY, P, S, US [isolectotypes]). Bautista Saavedra, Charazani, Jatichulaya, 16 Mar 1992, P. Gutte 104, fl. (LPB); La Paz, Cota Cota, avenida principal, 3400 m alt., 26 Mar 1983, E. García 403, fl. (LPB); suburb of Achumani on southesternmost side of La Paz, 16³2'S, 6804'W, 3400 m alt., 4 Dec 1984, M. Nee 30518, fl. (LPB, MO, NY); bajando de Charazani, 15¹0.40'S, 6857.68'W, $2874 \mathrm{~m}$ alt., 10 Feb 2003, J.R.I. Wood et al. 18937, fl. (LPB); Area Natural de Manejo Integrado Apolobomba, Charazani, 15¹0'49”S, 6859'45”W, 3187 m alt., 4 Sept 2004, A. Fuentes \& C. Aldana 6711, fl., fr. (MO). Loayza, município de Cairoma, Asiento Araca, Cerro Rosario, 1649'S, 67³3'W, 3820 m alt., 10 April 2004, S.G. Beck et al. 29317, fr. (LPB, NY); Sorata, 2800 m alt. 4 Dec 1983, S.G. Beck 8652 (LPB, NY, SI); arriba de los baños termales de Urmiri, 3500 m alt., 16 Dec 1989, S.G. Beck 17233, fl. (LPB, 
NY). Alto Irpavi, 3605 m alt., 6 Jan 1986, M. Moraes 690, fl. (LPB, NY) Sud Yungas, La Paz - Calacoto, $68 \mathrm{~km}$ hacia el Este, passando el Nevado Illimani, camino bajando por la estación generadora Ikiko, 3100-3500 m alt., 31 Dec 1980, S.G. Beck 3922, fr. (LPB, NY). Calacoto, $3300 \mathrm{~m}$ alt., hillsides on the north side, below Alto Irpavi, 16²'S, 6805’W, 16 Oct 1985, J.C. Solomon 14349, fl. (MO, NY). Songo, Nov 1890, A.M.B. Lectae 895, fl. (NY). PERU. Andahuaylas: above Argama, on trail to Andahuylas $3800 \mathrm{~m}$ alt., $5 \mathrm{Dec}$ 1935, J. West 3747 (GH [holotype], UC [isotype]); 2500-2600, 1909-1914, A. Weberbauer 5839 (F, G, GH). Cusco: Huayllabamba, trilha em direção à laguna Yanacocha, 13¹8'16.9'S, 7202'54.5'W, 3284 m alt., 12 Jan 2015, C.L. Silva-Luz \& L.F. Luz 334, 337, fl. (NY, RB, SPF); Ollantaytambo, quebrada Rumira, 1314'S, 72¹6'W, $3060 \mathrm{~m}$ alt., $17 \mathrm{Jul}$ 2003, I. Huamantupa et al. 3571, fl. (MO, NY); Ollantaytambo, Valle de Patacancha, $2900 \mathrm{~m}$ alt., May-Oct 1987 Steiphen \& J. Tait 32, fl. (USM); Huaytampo, 1312'00'S, 72²1'40”W, 3336 m alt., 10 Sept 2002, J. Farfán et al. 367, fl. (MO, NY); Huayoccari to Yanacoya, Urubamba, NW from Cusco, 1316'S, 7204'W, 14 Feb 1987, P. Nuñez et al. 7007, 7011 (MO); Calca, Parcco, 3230 m alt., 7 Jun 1987, K. van Eynde, sterile (MOL). Huamanga: Tambo, 3100-3200 m alt., May 1910, A. Weberbauer 5552, fr. (G, GH, S); Lucanas, Aucará, 3500 m alt., May 2004, L. Vargas \& G. Moura 205, sterile (USM).

Distribution. Schinus microphylla presents disjunct distribution occurring in south-central mountains of Apurímac, Ayacucho and Cusco, in Peru (Fig. 7C), in an area considered to be an important center of endemism for birds, mammals, amphibians and plants (Swenson et al., 2012), and in La Paz Department (Bolivia).

Ecology. Schinus microphylla occurs on humid rock slopes of the Peruvian and Bolivian pre-Puna, Puna and dry inter-Andean valleys (Fig. 7C), in which occurs in association with Polylepis forests, between 2500-3820 m. Schinus microphylla and $S$. subtridentata have contrasting distribution pattern, since no populations are known occurring in the cloud forests. It is known to flower in July-May, and fruit in Feb, April-June, Sept and Nov-Dec.

Conservation status. The IUCN threat status of $S$. microphylla was evaluated as Least Concern (LC) based on the extent of occurrence $\left(E O O=135,093.735 \mathrm{~km}^{2}\right)$ and as Endangered (EN) according to area of occupancy $\left(\mathrm{AOO}=88.000 \mathrm{~km}^{2}\right)$. We assign a preliminary IUCN threat status of Endangered (EN, A4) because most of the Bolivian records are nearby La Paz, an area under habitat loss to development. Also, no populations are known within protected area 
network in Bolivia. In Peru, populations are known nearby Area de Conservación Regional Choquequirao.

Common name. Molle, muluaca, checche (Spanish)

Discussion. When Macbride (1951) made the new combination $S$. microphylla var. andina (Engl.) J.F.Macbr., he mentioned that S. andina (Engl.) I.M. Johnst. seems to be a variant of $S$. microphylla but less pubescent with coriaceous leaves and smaller inflorescences. Schinus andina (Johnston, 1938), a name often applied to the Bolivian collections, is an illegitimate name because it was based on Schinus dependens Ortega var. andina Engl, which itself is illegitimate, because in 1883, Engler cited as a synonym the earlier name Schinus dependens var. parviflora Marchand (1869).

We examined the type material of $S$. dependens var. andina and $S$. dependens var. parviflora, and both specimens can be assigned to $S$. microphylla. Neither Cabrera (1938) nor apparently Barkley (1944) saw the type of $S$. dependens var. parviflora (Pentland 18, housed at $\mathrm{P}$ herbarium), which was collected in Bolivia; even so, Barkley made the combination S. polygama (Cav.) Cabrera var. parviflora F.A. Barkley, which he applied to Chilean material that here is considered to be $S$. polygama (species not treated in this taxonomic revision).

According to the morphological analysis of the specimens identified as $S$. microphylla and $S$. andina, we identified two morphotypes based mainly on leaf and inflorescence characteristics. The first morphotype that we recognize as belonging to $S$. microphylla presents branches ending in thorns (Fig. 4D, 5A,C), ranging from conspicuously thorny (Peruvian specimens) to inconspicuously so (Bolivian specimens), and branches and leaves with strigose indumentum (something uncommon in other species). Moreover, it has leaves with the secondary vein angle smoothly decreasing toward base (Fig. 4E, 5A,B), staminate inflorescences with median internodes 1.7-3.5 mm long (Fig. 5D), staminate flowers with the pedicel 1.5-3 mm long, pistillate inflorescences with median internodes c. $1.7 \mathrm{~mm}$ long; and pistillate flowers with pedicels $2-3.3 \mathrm{~mm}$ long. The second morphotype which we recognize as $S$. subtridentata bears unarmed or inconspicuously armed branches (Fig. 8N); leaves with secondary vein angle uniform, irregular or smoothly increasing toward base (Fig. 8I,L,M); staminate inflorescences with median internodes 1-2 mm long (Fig. 8J); staminate flowers with pedicels 1.4-1.6 mm long; pistillate inflorescences with median internodes $1-1.5 \mathrm{~mm}$ long; and pistillate flowers with pedicels 1-2 mm long (Fig. $80, P$ ). According to the morphological features mentioned above, S. microphylla has staminate and pistillate structures (i.e. pedicel and median internodes of the inflorescences) larger than $S$. subtridentata. Even 
though there is some degree of overlap between them, S. microphylla can be differentiated by its branches and leaves with strigose indumentum (unlike the puberulous and clavate-glandular indumentum which is common for almost all species). In contrast, $S$. subtridentata has branches and leaves hirsute (besides the clavate-glandular indumentum) and dull pedicel and sepals. Based on these morphological distinctions, we decided to treat them as different species, $S$. microphylla and S. subtridentata (Kuntze) Silva-Luz. Even though the majority of specimens identified as $S$. andina correspond to the second morphotype, we cannot use this epithet because it is an illegitimate name, and also because we identified its type material as belonging to $S$. microphylla. Schinus microphylla occurs in sympatry with S. subtridentata, S. minutiflora and S. congestiflora in La Paz. The former species is distinct from the three latter species because its branches are usually conspicuously thorny (vs. inconspicuously thorny or unarmed) and staminate inflorescences with longer median internodes 1.7-3.5 mm (vs. 1-2 mm, 1-1.4 mm and 0.5-1.5 mm, respectively). Schinus microphylla also can be found in the same area as $S$. pearcei and $S$. areira (neither species treated in this taxonomic revision) in ecotones between montane cloud forests and pre-Puna, Puna or dry interAndean valleys. Schinus microphylla is readily recognized because of its armed branches, simple leaves and pseudoracemose inflorescences, whereas the two latter species have unarmed branches, compound and dissected leaves, and paniculate inflorescences. Johnston (1938) reported that the flowers of $S$. microphylla are pentamerous, but all specimens examined by us have tetramerous flowers, as in all species of Schinus section Myrtifolia.

5. Schinus minutiflora (Loes.) Silva-Luz, comb. nov., nom. nov. \& stat. nov. $\equiv$ Schinus dependens var. andina Engl. fo. grandifolia Loes., syn. nov., Mededeelingen van's Rijks Herbarium 27: 84. 1915. - Type: Subalpinen Gebüshes bei Samaipata, ca. 2000 m, Mar 1911, T.C.J. Herzog 1714 (holotype: S [photo]!).

Figures: $2 \mathrm{H}-\mathrm{P}, 7 \mathrm{D}$

Description. Shrubs, sometimes tree(lets), 1-4 m tall. Branches erect, unarmed, puberulous or pilose, sometimes tomentose. Trichomes simple or barbellate and transparent, or clavate-glandular and transparent, orangish-red or brown; erect, straight, arcuate, nutant or slightly sigmoid, $0.03-0.1 \mathrm{~mm}$ long on branches, leaves, and inflorescences. Leaves not congested; petiole 2-5 mm long, canaliculate or semi-terete, on both surfaces densely pilose, puberulous or clavate- 
glandular; blade (1.5-) 1.9-3 x 1-3.3 cm, often (broadly) ovate, sometimes elliptic or obovate; apex obtuse, rounded, sometimes retuse; medially asymmetrical, basal insertion (sub)symmetrical, base width usually asymmetrical, obtuse or acute, rounded or decurrent; margin entire on proximal portion, crenate, serrate or serratecrenate on distal portion, slightly revolute on proximal portion, sometimes pilose; texture membranaceous or chartaceous, surface sometimes glossy; costal secondaries in (5-) 6-10 pairs, spacing irregular, course sinuous or straight, angle uniform or smoothly increasing toward base, rarely irregular; marginal secondary vein 0.03-0.09 $\mathrm{mm}$ in width, inconspicuous; tertiary veins visible; on abaxial side the midvein prominent or flat proximally and prominulous or flat distally, secondary veins flat, tertiary veins flat, glabrous or sparsely clavate-glandular; on adaxial side the midvein prominent or flat proximally and prominulous or flat distally, secondary veins flat or impressed, rarely prominulous, tertiary veins flat, sometimes pilose on midvein, rest of surface puberulous or sparsely clavate-glandular. Inflorescences axillary or terminal, clavate-glandular or puberulous; bracts monomorphic, 0.3-0.6 x 0.3-0.8 mm, (broadly) deltate; bracteoles 0.1-0.2 x 0.1 mm, ovate or lanceolate; bracts and bracteoles densely pilose or clavate-glandular on both surfaces; pedicel puberulous or clavate-glandular, bracteoles subtending pedicel; sepals puberulous or clavate-glandular on both surfaces; petals with midvein sometimes branching at apex and 1-3 cladodromous secondary veins, essentially glabrous; disk 0.1-0.3 mm tall and ca. $0.08 \mathrm{~mm}$ thick, glabrous. Staminate inflorescences 6-8 $\mathrm{mm}$ long, flowers in congested pseudoracemes, often branched at base, median internodes 1-1.4 mm long. Staminate flowers with pedicel (0.5-) 0.9-1.5 mm long overall, portion distal to articulation $0.5 \mathrm{~mm}$ long or the articulation not visible; sepals $0.3-0.6 \times 0.5-0.7 \mathrm{~mm}$, (broadly) ovate or obovate; petals 1-1.5 x 0.8-1.2 mm, ovate, convex; antesepalous and antepetalous stamens $0.6-1$ and $0.6 \mathrm{~mm}$ long, respectively; anthers $0.2-0.3 \mathrm{~mm}$ long, (broadly) oblong in dorsiventral and lateral views; pistillode 0.2-0.3 mm long. Pistillate inflorescences 5-9 mm long, flowers in lax pseudoracemes or solitary, median internodes $0.8-0.9 \mathrm{~mm}$ long. Pistillate flowers with pedicel 1-2 mm long overall, portion distal to articulation 0.5-0.8 mm long; sepals 0.4-0.6 $\times$ 0.4-0.6 mm, ovate; petals $0.8-1.4 \times 0.6-1 \mathrm{~mm}$, ovate or oblong, concave; pistil $0.9-1.1 \mathrm{~mm}$ long overall, glabrous; ovary globose, style $0.1 \mathrm{~mm}$ long, glabrous stigmas; antesepalous and antepetalous staminodes all 0.3-0.5 mm long, anthers 0.1-0.3 mm long. Fruiting pedicel 2-4 mm long overall, portion distal to articulation 0.6-0.8 mm long, puberulous or clavate-glandular, sometimes pilose. Drupes 4-5 x 4.8-6 mm, pinkishred, obliquely globose or ovoid, glabrous. 

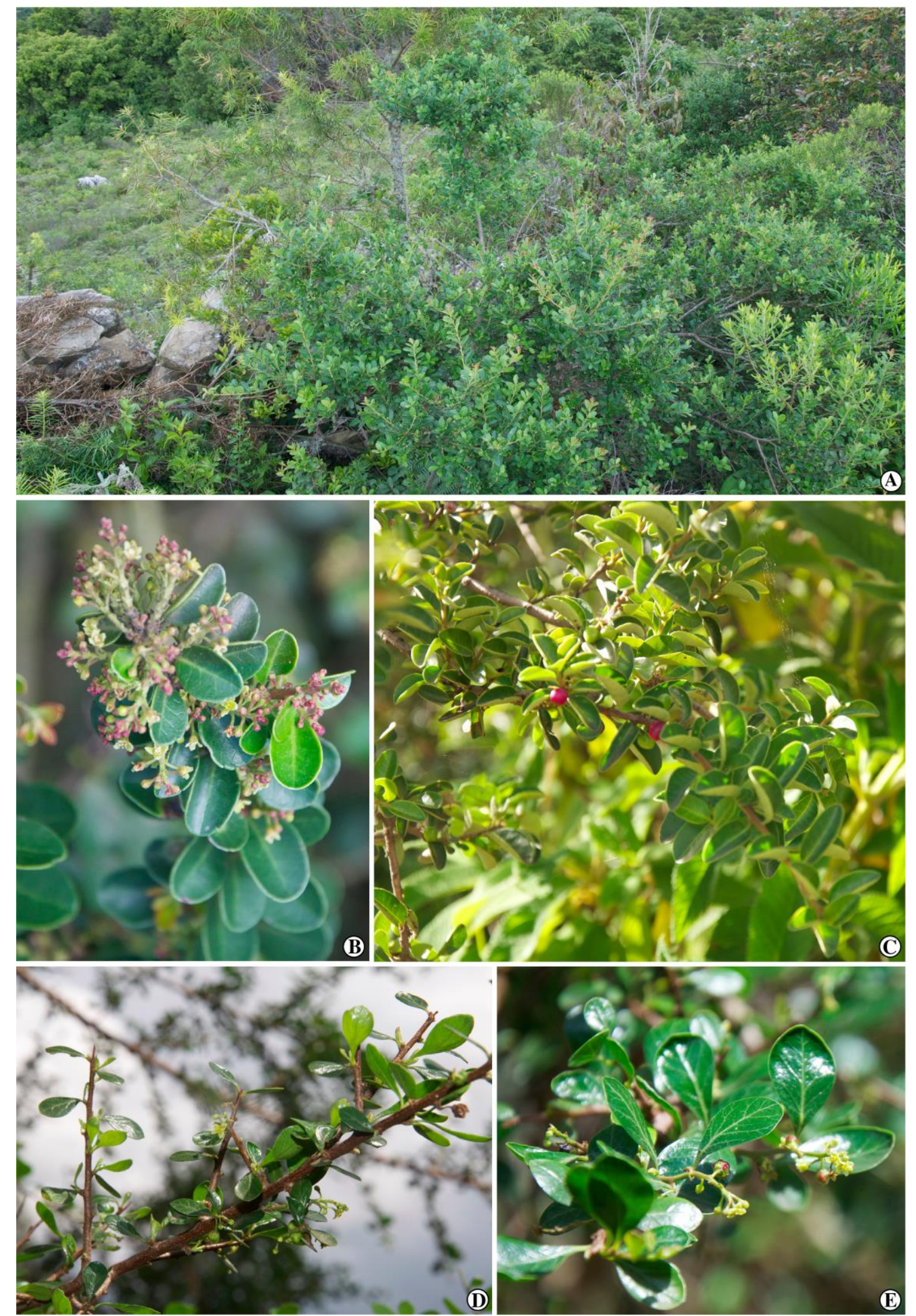

Fig. 4. A-B: Schinus congestiflora. A. Habit; B. Flowering branchlet with staminate inflorescences (note conspicuous marginal secondary vein); C. Fruiting branchlets. D-E: Schinus microphylla. D. Flowering branchlets with staminate flowers; E. Flowering branchlets (note the glossy blade and the venation). Pictures: C.L. Silva-Luz. 
Specimens examined. BOLIVIA. Cochabamba: Siberia, 17048'11'’S, 6446'12’W, 2900 m alt., 16 April 2005, E. Fernández et al. 3553, fr. (BOLV, LPB); $5 \mathrm{~km}$ al este del puente sobre el río Lopez Mendoza por el camino entre Cochabamba y Santa Cruz (19 km al oeste de Epizana), 17³2'S, 6522'W, $2900 \mathrm{~m}$ alt., 11 Feb 1987, J.C. Solomon \& M. Nee 16035, fr., 16041, fr. (MO, NY). Chuquisaca: Hernando Siles, Huacareta, serrania Los Milagros, subiendo el sendero al pastizal, 20¹9'46”'S, 6402'32’W, 1854 m alt., 26 Dec 2005, M. Serrano et al. 6985, fr. (HSB, MO, NY); primera sección Monteagudo, canton Fernandez, comunidad Vallecito, Canon El Guayavillar, 20¹2'04'S, 64¹7'54'’W, 2438 m alt., 9 Nov 2007, O. Apaza et al. 32, fr. (HSB, MO). Juana Azurduy de Padilla, primeira sección Villa Azurduy, 2006'09”S, 64²5'06”W, 2507 m alt., 13 Nov 2007 M. Jimenez et al. 678, fl., fr. (HSB, MO); 2 km SW Tarvita on Tarabuco -Azurduy road, $19^{\circ} 57^{\prime} \mathrm{S}, 64^{\circ} 31^{\prime} \mathrm{W}, 2750 \mathrm{~m}$ alt., 25 Sept 1991, M. Kessler 3243, fl. (NY). Tomina, trayecto Lampacillos-El Rosal, 19²5'21'S, 6411'36'W, 2398 m alt., 21 Dec 2005, M. Serrano et al. 6805, fl., fr. (HSB, MO, NY); ca. $10 \mathrm{~km}$ saliendo del El Villar hacia Alcala, 19³4'00.5'S, 6419'56.4'W, 2552 m alt., 8 Jan 2004, A. Carretero et al. 1197, fr. (HSB, NY); Padilla, 25 km hacia Monteagudo, $2400 \mathrm{~m}$ alt., 1 Oct 1983, S.G. Beck \& M. Liberman 9348, fl. (LPB, NY). Padilla, $21 \mathrm{~km}$ hacia Monteagudo, $2370 \mathrm{~m}$ alt., 8 March 1981, S.G. Beck 6296, fl. (LPB, NY); a 6 km en el camino saliendo del Villar hacia Alcalá, 19³5.524’S, 64⒚028’W, 2309 m alt., 2 April 2003, J.R.I. Wood et al. 19554, fr. (HSB, LPB). Santa Cruz: Florida, Strauch des subalpinen Gebüshes bei Samaipata, ca. 2000 m, Mar 1911, T.C.J. Herzog 1714, fl. (S [holotype]). José María Caballero, Comarapa, 20 Oct 1928, J. Steinbach 8346, fl. (GH, MO). Vallegrande: El Palmar, camino entre Vallegrande - Postrer Grande, 26 km de Vallegrande, 18²8'S, 635'W, 2400 m alt., 22 Aug 1994, M. Moraes \& I. Vargas 1809, fl. (LPB, NY); juntas de Waricongas, $14 \mathrm{~km}$ SE de Vallegrande, 18`34'S, 640’W, 1825 m alt., 30 Dec 1988, M. Saldías 546, fr. (NY); Guapural, ca. $41 \mathrm{~km}$ sur de Vallegrande, camino a Gualasi, 1840'S, 6401'W, 27 Feb 2002, L. Arroyo et al. 1883, fl. (NY, USZ); camino principal de Vallegrande a Masicurí, 1-2 km antes de Loma Larga, 18¹4'46”'S, 6354'04'W, 1995 m alt., 23 Aug 2008, L. Arroyo et al. 3875, fl. (MO, NY, USZ); $3 \mathrm{~km}$ (by air), $S$ of Khasa Monte on road to

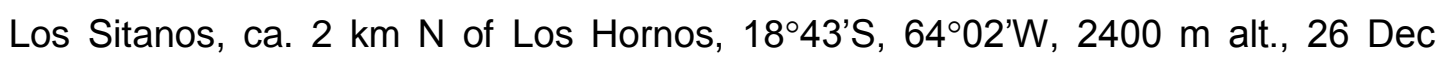
1989, M. Nee 38420, fl., fr. (NY); ca. 6 km S of Abra Tablas on road to Los Sitanos,

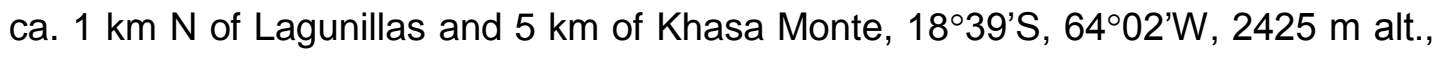
26 Dec 1989, M. Nee 38397, fr. (NY); Aguadita, 8 km (by air) S of Khasa Monte on 
road to Los Sitanos, $18^{\circ} 47^{\prime}$ S, $64^{\circ} 02^{\prime}$ W, 2350 m alt., 26 Dec 1989, M. Nee 38440, fr. (NY).

Distribution. Bolivian endemic species occurring mostly in Chuquisaca and Santa Cruz departments, and scattered populations in Cochabamba (Fig. 7D).

Ecology. Schinus minutiflora occurs in shrubby areas, leaning on other plants and on rocky slopes of Tucumán-Bolivian forests and Yungas (Fig. 7D), associated with Prumnopitys, Podocarpus, Alnus and Polylepis forests and in ecotones between these forests and pre-Puna or dry inter-Andean valleys, between $1825-2900 \mathrm{~m}$. It is known to flower in Feb-March and Aug-Dec, and fruit in Nov-Feb and April.

Conservation status. The IUCN threat status of $S$. minutiflora was evaluated as Near Threatened (NT) based on the extent of occurrence $\left(E O O=24,831.545 \mathrm{~km}^{2}\right)$ and as Endangered (EN) according to area of occupancy $\left(A O O=64.000 \mathrm{~km}^{2}\right)$. We assign a preliminary IUCN threat status of Endangered (EN, A4) based on the area of occupancy rather than the extent of occurrence because the latter parameter likely encompasses unsuitable habitats (i.e., Puna, pre-Puna and dry inter-Andean valleys). No populations are known within protected areas network in Bolivia. However, some populations are nearby Carrasco and Amboró National Parks.

Common name. Wizluru (Quechua)

Discussion. Specimens of $S$. minutiflora match the type material of $S$. dependens var. andina fo. grandifolia Loes. Here $S$. dependens var. andina is subsumed under $S$. microphylla. Since we decided to recognize this forme as a distinct species, there is no reason to keep the epithet "grandifolia," especially because other Schinus species have substantially larger leaves (e.g. S. meyeri), and instead we propose the epithet minutiflora referring to the small inflorescences.

Barkley (1957) considered $S$. dependens var. andina fo. grandifolia (= $S$. minutiflora) to be synonymous with $S$. myrtifolia. Schinus minutifolia has leaves that are essentially broadly ovate (FIG. $2 \mathrm{H}, \mathrm{I}, \mathrm{L}, \mathrm{N})$ but, like $S$. myrtifolia, sometimes its leaves are elliptic or obovate (Fig. $2 \mathrm{M}, \mathrm{N}$ ). However, $S$. minutiflora is easily distinguished because it has branched staminate pseudoracemes 6-8 $\mathrm{mm}$ long (Fig. $2 \mathrm{H}$; vs. unbranched staminate pseudoracemes $15-30 \mathrm{~mm}$ long - Fig. $5 \mathrm{~F}$ ), and the pistillate inflorescences 5-9 mm long (Fig. $2 \mathrm{~N}$ ) with the median internodes 0.8-0.9 $\mathrm{mm}$ long (vs. pistillate inflorescences 9-23 mm long (Fig. 5L) with the median internodes 2-3.5 $\mathrm{mm}$ long). Overlap in pistillate inflorescences length may complicate identification of $S$. minutiflora (5-9 mm long) and $S$. congestiflora (3-14 $\mathrm{mm}$ long), especially when populations occur in sympatry. Female individuals can 

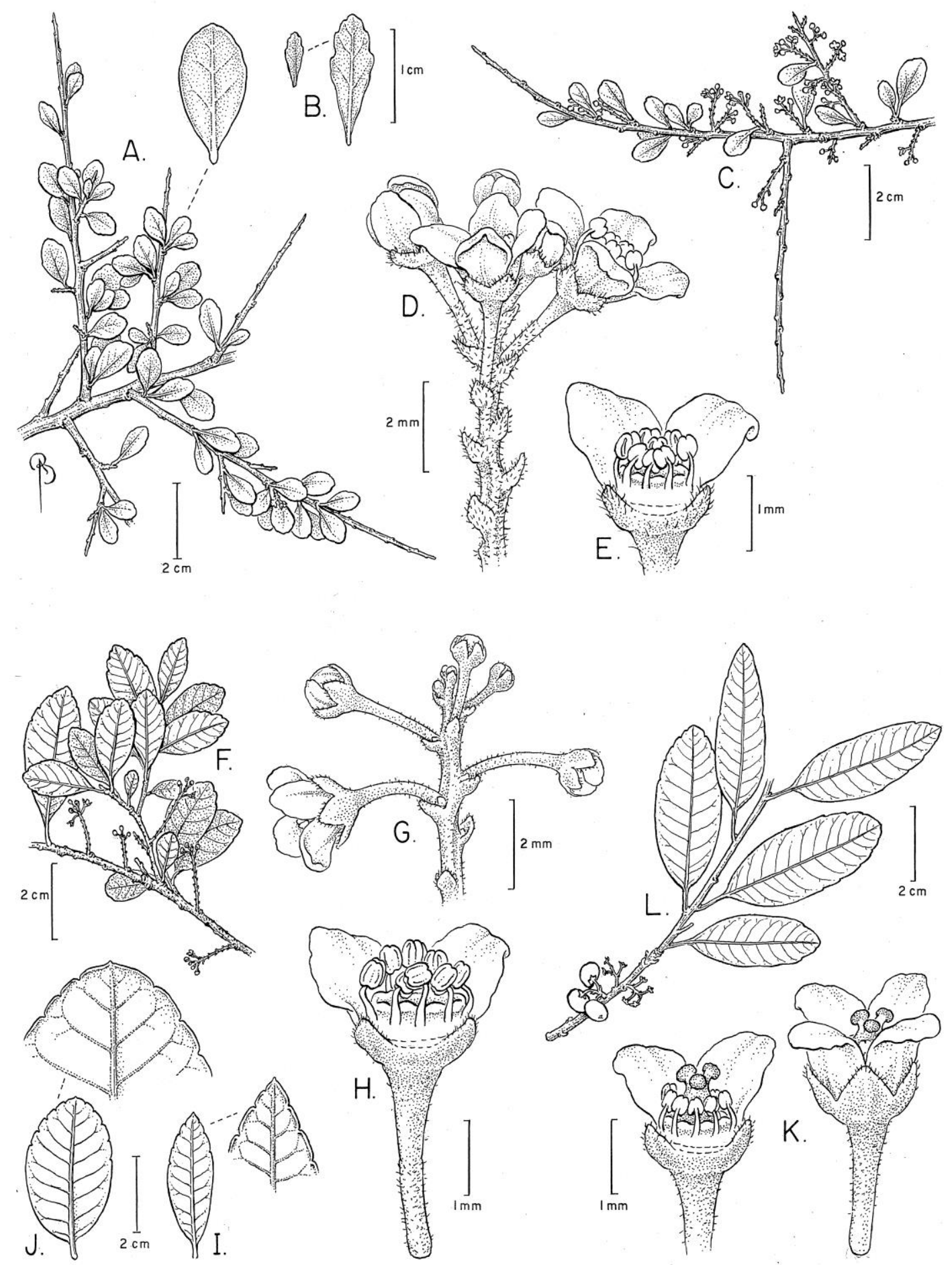

Fig. 5. A-E: Schinus microphylla. A. Sterile branchlet; B. Leaf plus detail of the venation and margin (inset); C. Flowering inflorescence; D. Staminate inflorescence; E. Staminate flower with two petals and one sepal removed. F-L: Schinus myrtifolia. F. Flowering branchlet; G. Inflorescence; H. Staminate flower with two petals and one sepal removed; I. Leaf plus detail of the venation and margin on distal portion (inset); J. Leaf plus detail of the venation and margin on distal portion (inset); K. Pistillate flower plus detail of the flower with two petals and one sepal removed; L. Fruiting branchlet. 
be distinguished by pistil length (fig. $20,0.9-1.1 \mathrm{~mm}$ long, vs. $0.7-0.8 \mathrm{~mm}$ in $S$. congestiflora, fig. 2G). Schinus minutiflora may also co-occur with S. subtridentata and S. microphylla in Chuquisaca and $\mathrm{La}$ Paz departments, but it is readily distinguished by its unarmed branches (Fig. $2 \mathrm{H}, \mathrm{N}$ ), whereas S. microphylla has armed branches (Fig. 4D, 5A,C), and $S$. subridentata has inconspicuous armed branches (Fig. $8 \mathrm{~N}$ ), leaves with tertiary veins inconspicuous but visible (vs. not noticeable in S. microphylla and $S$. subtridentata) and pistillate inflorescences with median internodes 0.8-0.9 mm long (vs. 1-1.5 mm long and 1.7-2 mm long, in $S$. subtridentata and $S$. microphylla, respectively). Besides, S. minutiflora has fruiting pedicel of 2-4 $\mathrm{mm}$ long overall, whereas in $S$. microphylla the fruiting pedicel is $1.5-1.8 \mathrm{~mm}$ long overall. Schinus minutiflora can be found in sympatry with $S$. pilifera, S. pearcei and $S$. areira (these species not treat in this taxonomic revision), in ecotones between montane cloud forests and dry inter-Andean valleys, Puna or pre-Puna, especially in Cochabamba and La Paz departments. Schinus pilifera differs by its armed branches, whereas $S$. pearcei has dissected leaves and $S$. areira has compound leaves (vs. unarmed branches and simple leaves in $S$. minutiflora).

6. Schinus myrtifolia (Griseb.) Cabrera in Frenguelli, Investigaciones geológicas en la zona salteña del Valle de Santa Maria (Universidad Nacional de La Plata, Instituto del Museo, Obra del Cincuentenario ii.) 269. 1937. इ Cybianthus myrtifolius Griseb., Symbolae ad Floram Argentinam 222. 1879. - Lectotype (designated here): Argentina, Salta, Yacone cerca de Salta, Mar 1873, P.G. Lorentz \& G.H.E.W. Hieronymus 317 (GOET [photo]!; isolectotypes: CORD, LP [photo]!).

Figures: 5 F-L, 6 A-G, 7 B

Description. Tree(lets) or shrubs, 2-7 $\mathrm{m}$ tall. Branches prostrate, unarmed, often glabrous, sometimes puberulous or clavate-glandular. Trichomes simple and transparent or clavate-glandular and transparent or orangish-yellow; erect or appressed, straight, slightly sigmoid or arcuate, 0.06-0.1 mm long on branches, 0.01-0.03 mm long on leaves and 0.03-0.04 mm long on inflorescences. Leaves not congested; petiole 2-8 (-11) mm long, canaliculate, puberulous or sparsely clavateglandular; blade 2-6 x 1.2-3 cm, essentially (broadly) elliptic or oblong, rarely ovate; apex usually obtuse, sometimes acute, rounded or straight; medially (sub)symmetrical, basal insertion (sub)symmetrical, basal width asymmetrical, base acute, rarely obtuse, base decurrent; margin often entire, sometimes entire on 
proximal portion and (slightly) crenate on distal portion, slightly revolute, sparsely strigose; membranaceous or chartaceous, glossy; costal secondaries in 8-16 pairs, spacing often irregular, course arcuate, angle uniform or irregular; marginal secondary vein $0.03-0.1 \mathrm{~mm}$ in width, inconspicuous; tertiary veins visible; on abaxial side the midvein prominent or prominulous proximally and flat distally, secondary veins flat or prominulous, tertiary veins flat, essentially glabrous; on adaxial side the midvein prominulous or flat, secondary veins impressed or flat medially and impressed toward margin, tertiary veins impressed, sparsely clavateglandular, puberulous or pilose on midvein. Inflorescences axillary or terminal, puberulous or sparsely clavate-glandular; bracts monomorphic, 0.5-0.8 x 0.3-0.6 $\mathrm{mm}$, ovate or deltate; bracteoles $0.2-0.3 \times 0.1-0.3 \mathrm{~mm}$, ovate or oblong; bracts and bracteoles pilose or clavate-glandular on abaxial surface and margin, glabrous or clavate-glandular on adaxial surface; pedicel sparsely pilose, puberulous or clavateglandular, bracteoles subtending pedicel; sepals puberulous or sparsely clavateglandular on both surfaces, conspicuous on margin; petals with midvein sometimes branching at apex and 3 cladodromous secondary veins, essentially glabrous, rarely puberulous or clavate-glandular on both surfaces; disk 0.5-0.7 mm tall, 0.1-0.2 mm thick, glabrous. Staminate inflorescences $15-30 \mathrm{~mm}$ long, flowers in unbranched pseudoracemes, median internodes $0.8-1.8 \mathrm{~mm}$ long. Staminate flowers with pedicel $1.5-5 \mathrm{~mm}$ long overall, portion distal to articulation $0.4-0.7 \mathrm{~mm}$ long or the articulation not visible; sepals $0.6-1 \times 0.5-0.9 \mathrm{~mm}$, oblong or ovate; petals $1.2-1.9 \mathrm{x}$ 1-1.4 mm, ovate, obovate or oblong, convex; antesepalous and antepetalous stamens 0.9-1.1 and 0.8-1 mm long, respectively; anthers 0.3-0.4 mm long, (broadly) oblong in dorsiventral view, ovate or (broadly) oblong in lateral view; pistillode 0.3-0.4 mm long. Pistillate inflorescences $9-23 \mathrm{~mm}$ long, flowers in unbranched pseudoracemes, median internodes $2-3.5 \mathrm{~mm}$ long. Pistillate flowers with pedicel 2-3.3 $\mathrm{mm}$ long overall, portion distal to articulation $0.1 \mathrm{~mm}$ or the articulation not visible; sepals $0.6-0.7 \times 0.6-0.7 \mathrm{~mm}$, ovate or oblong; petals 1.2-1.4 $x$ 0.8-0.9 mm, ovate or oblong, slightly convex; pistil $0.8 \mathrm{~mm}$ long overall, glabrous; ovary globose, style $0.1 \mathrm{~mm}$ long; antesepalous and antepetalous staminodes 0.4 $\mathrm{mm}$ long and $0.3 \mathrm{~mm}$ long, respectively, anthers $0.2 \mathrm{~mm}$ long. Fruiting pedicel 2.4-7 $\mathrm{mm}$ long overall, articulation $0.4-2 \mathrm{~mm}$ long or the articulation not visible, puberulous. Drupes 5.5-7.3 x 5.8-8 mm, pink or red, obliquely obovoid, laterally compressed, glabrous or sparsely clavate-glandular.

Specimens examined. ARGENTINA. Jujuy: Ledesma, Abra de Cañas, ruta provincial 3, camino a Valle Grande, 1720 m alt., 28 Oct 1970, F. Vervoorst \& A.R. Cuezzo 7625 C, fl. (LIL, NY); rota provincial 4 em direção a termas de Reyes, 

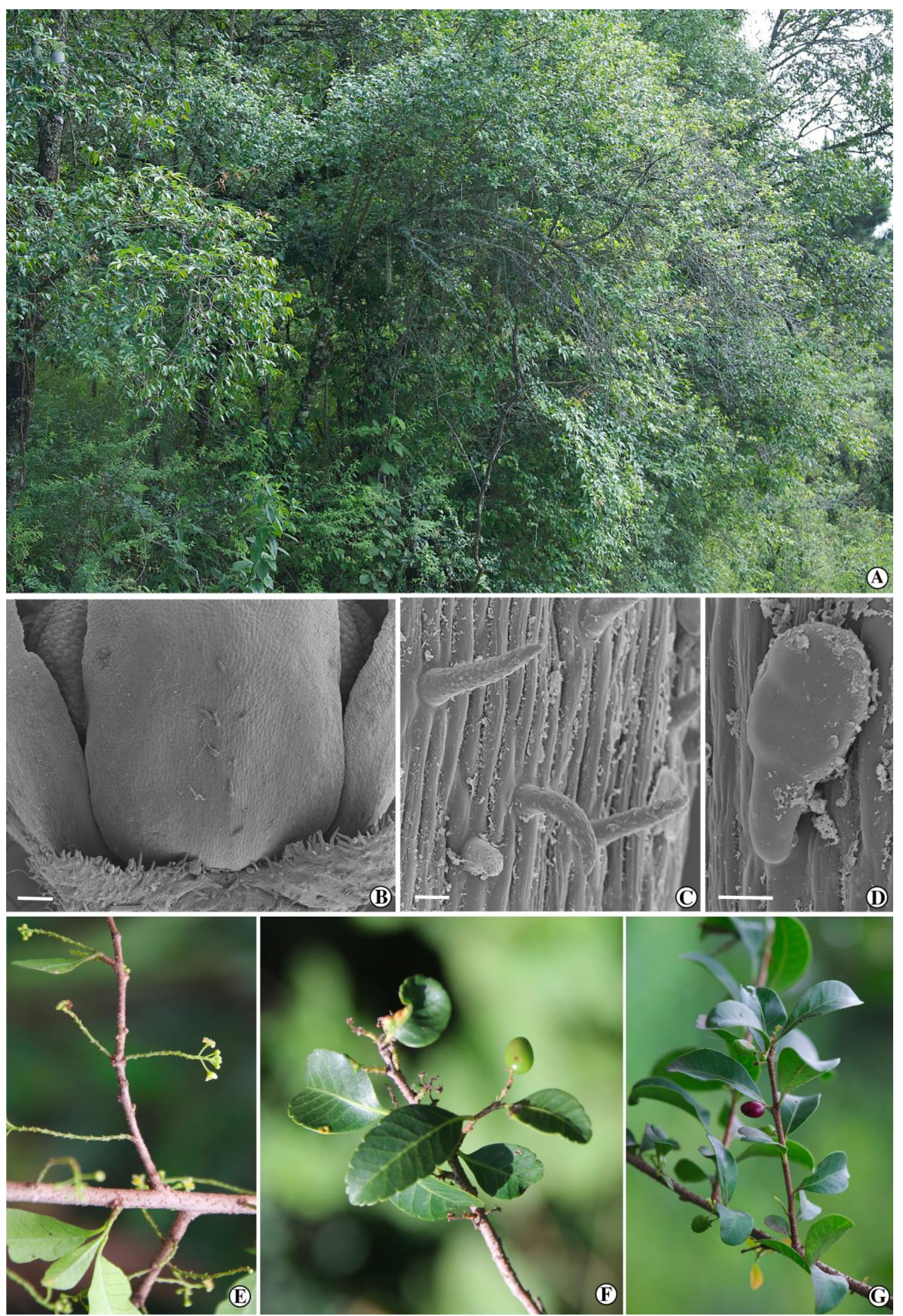

Fig. 6. Schinus myrtifolia: A. Habit; B. Lateral view of flower showing simple and glandular trichomes on sepals and petal, (scale bar $100 \mu \mathrm{m}$ ); C. Barbellate trichomes on pedicel (scale bar $10 \mu \mathrm{m}$ ); D. Clavate-glandular trichome (scale bar $10 \mu \mathrm{m}$ ); E. Unbranched pseudoraceme with staminate flowers; F. Branchlet with immature fruit; $G$. Branchlet with mature fruit and pistillate inflorescence in development. Pictures: A and E-G, C.L. Silva-Luz; B-C, E. Tolke. 
2410'43.9'S, 65²7'12'W, 1659 m alt., 18 Dec 2014, C.L. Silva-Luz \& L.F. Luz 325, fl., fr. (NY, RB, SPF); Oct 1892, O Kuntze s.n., fl. (NY); depto Tumbaya, Volcan, cerca cementerio y cantera, 2100 m alt., 30 Jan 1999, S.G. Beck \& N. Paniagua 26780, fr. (CTES, LPB, M, NY); $11 \mathrm{~km}$ del desvio de la ruta nacional 9, camino a Tiraxi, 10 Dec 1998, O. Morrone et al. 3247, fr. (MBM, SI); Zapla, 9 Nov 1974, A. Burkart et al. 30523, fl., fr. (LP, SI); Parque Nacional Calilegua, rota provincial 83 em direção a Valle Grande, em estrada de terra não pavimentada, lado esquerdo, 2341'25.9”S, 6452'43.0'W, 1440 m alt., 17 Dec 2014, C.L. SilvaLuz \& L.F. Luz 322, fl. (NY, RB, SPF); rota provincial 4 em direção a termas de Reyes, 24¹1'0.8.6”'S, 65²7'00.9'W, 1614 m alt., 18 Dec 2014, C.L. Silva-Luz \& L.F. Luz 324, fl. (NY, RB, SPF); Yala, 2 Nov 1974, A. Schinini et al. 10066, fl. (CTES); Yala, side valley from main Humahuaca valley, 1400 m alt., 13 Nov 1978, S.A. Renvoize et al. 3458, fl. (K, NY, SI); Valle Grande, 2 Dec 1969, P.R. Legname \& A.R. Cuezzo 7274 C, fl. (LIL, NY). Salta: Yacone cerca de Salta, Mar 1873, P.G. Lorentz \& G.H.E.W. Hieronymus 317 (lectotype: GOET, isolectotypes: CORD, LP); La Caldera, Lessen, 1850 m alt., 16 Nov 1980, S.R. Zapata 43, fl., fr. (NY); La Caldera, entre Yacones y Potrero del Castillo, 1700-2200 m alt., 12 March 1952, H. Sleumer \& F. Vervoorst 2787, fr. (LIL, NY); La Caldera, rota 9 em direção a Salta, 24³1'23.6”'S, 65²1'17.9”'W, 1561 m alt., 19 Dec 2014, C.L. Silva-Luz \& L.F. Luz 327, fl. fr. (NY, RB, SPF); sierras entre La Viña y Amblair, 15 Feb 1943, Castellanos, fr. (BA 46827); San Lorenzo, rota 115 em estrada de terra, 24³9'15.6”S, 65²9'01.6”'W, 1528 m alt., 26. Mar 2014, C.L. Silva-Luz \& L.F. Luz 288, fr. (NY, RB, SPF); San Lorenzo, 460 m alt., s.d., J.S. Biloni 6023, fl. (SI); rota nacional 9, de El Carmén a Salta, próximo ao dique, 24³1'53.3”S, 65²2'03.4”W, 1519 m alt., 28 Mar 2014, C.L. Silva-Luz \& L.F. Luz 292, fr. (NY, RB, SPF); rota nacional 9, de El Carmén a Salta, próximo ao dique, 24³2’32.6”'S, 65²1'49.7”W, 1643 m alt., 28 Mar 2014, C.L. Silva-Luz \& L.F. Luz 293, fr. (SPF); La Caldera, rota 9 em direção a Salta, 24³1'23.6”'S, 65²1'17.9'W, 1561 m alt., 19 Dec 2014, C.L. Silva-Luz \& L.F. Luz 326, fl. (NY, RB, SPF); Salta, lagunas de Yala, 4 Jan 1971, A. Krapovickas \& C.L. Cristóbal 17489, fr. (MBM). BOLIVIA. Chuquisaca: Sud Cinti, Puca Pampa, aproximadamente a $5 \mathrm{~km}$ de puesto ganadero, en la parte NW del río Alborniyoj., 2044'S, 64³0'W, 2100 alt., 8 Feb 2004, J. Gutiérrez et al. 500, fr. (HSB, MO, NY). Tarija: Aniceto Arce, El Carmen, 2201'46”'S, 6450'29''W, $2600 \mathrm{~m}$ alt., 12 Feb 2006, F. Zenteno et al. 3690, fr. (LPB, NY). Burnet O'Connor, rota 11, de Entre Ríos a Tarija, a cerca de 184 km de Villamontes, 21²4'22.4'S, 6417'35.6”'W, 1976 m alt., 9 Jan 2014, C.L. Silva-Luz \& L.F. Luz 243, fl. (NY, RB, 
SPF); rota 11, de Entre Ríos a Tarija, a cerca de $184 \mathrm{~km}$ de Villamontes, 21'24'45.0"S, 7417'19.4'W, 1907 m alt., 9 Jan 2014, C.L. Silva-Luz \& L.F. Luz 241, fr. (NY, RB, SPF); rota 11, de Entre Ríos a Tarija, a cerca de $184 \mathrm{~km}$ de Villamontes, 21²4'33.2”'S, 74¹7'35.6”W, 1976 m alt., 9 Jan 2014, C.L. Silva-Luz \& L.F. Luz 242, fr. (NY, RB, SPF). Eustaquio Méndez, 10.4 km SW Tomatas (5 km N of Tarija), rincon de La Victoria, 21³2'S, 6450’W, 2200-2300 m alt., 10 May 1983, J.C Solomon 10610, fl. (MO, NY).

Distribution. Schinus myrtifolia is relatively widely distributed in northwestern Argentina, in Jujuy and Salta provinces, with scattered populations in southern Bolivia, in Tarija and Chuquisaca departments (Fig. 7B).

Ecology. Schinus myrtifolia occurs in the Tucumán-Bolivian forests (Fig. 7B) associated with Alnus and Podocarpus forests, sometimes in shrubby areas, between 1400-3000 m. According to Muñoz (2000) this species also can be distributed in ecotones between montane cloud forests and Chaco, pre-Puna, Puna or dry inter-Andean valleys. Schinus myrtifolia is often associated with horco quebracho (Schinopsis marginata Engl.), a common species of northwestern Argentina. It is known to flower in Oct-Jan and May, and fruit in Nov-March.

Conservation status. The IUCN threat status of $S$. myrtifolia was evaluated as Vulnerable (VU) based on the extent of occurrence $\left(E O O=18,971.115 \mathrm{~km}^{2}\right)$ and as Endangered (EN) according to area of occupancy $\left(\mathrm{AOO}=56.000 \mathrm{~km}^{2}\right)$. There are numerous collections of $S$. myrtifolia, but mainly from sparse road network in Bolivia and Argentina. Low collection densities in the montane cloud forests are probably due either to the difficulty to access them or to fieldwork gap, especially nearby the boundary between Argentina and south Bolivia. Also, populations are known within Calilegua National Park (Argentina) and in the vicinity of Tariquía Flora and Fauna National Reserve (Bolivia). Hence we assign a preliminary IUCN threat status of Vulnerable (VU, A4).

Common name. Molle (Spanish)

Discussion. When Grisebach (1879) described Cybianthus myrtifolius Griseb. (the basionym of $S$. myrtifolia), he cited two syntypes. For one, in the publication he mentioned "Yacone," without collector and collection number. According to Varela \& Novara (2007), Yacone is a locality in Salta province (Argentina) with dense populations of S. myrtifolia. There is a collection of Lorentz \& Hieronymus 317, housed at GOET, which was collected in Yacone in 1873 and determined as Cybianthus myrtifolius. As the GOET herbarium contains most of type materials of Grisebach (Stafleu \& Cowan, 1976), and as the collections of Lorentz \& Hieronymus were used to produce the treatment of the Symbolae ad 


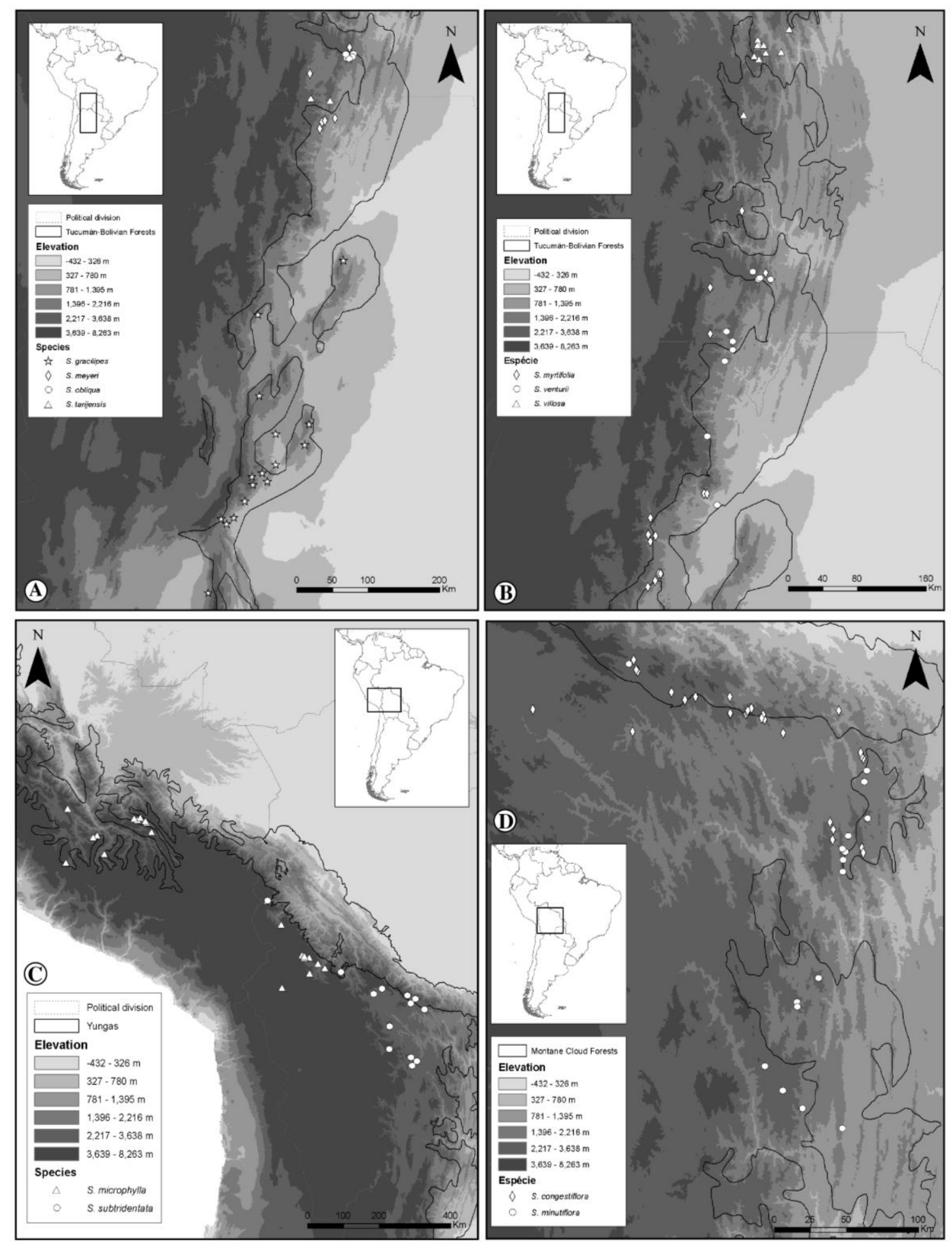

Fig. 7. A. Distribution of $S$. gracilipes, S. meyeri, $S$. obliqua and S. tarijensis. B. Distribution of $S$. myrtifolia, $S$. venturii and $S$. villosa. C. Distribution of $S$. microphylla and $S$. subtridentata. D. Distribution of $S$. congestiflora and $S$. minutiflora. 
floram Argentinam, this specimen can be assigned to that cited by Grisebach. The second collection cited was Balansa 2381, collected in Paraguay. Examination of these specimens shows that Lorentz \& Hieronymus 317 is S. myrtifolia, while Balansa 2381 is a species of Prunus (Rosaceae). When Cabrera (1937) transferred Cybianthus myrtifolius to Schinus, he did not mention the type material. Subsequently (1938) he cited Lorentz \& Hieronymus 317 as the type but did not mention Balansa 2381, nor did Barkley (1957). Although we agree with Cabrera and Barkley about the choice of the type material, it still needed to be lectotypified, thus we chose as lectotype Lorentz \& Hieronymus 317 housed at GOET. Cabrera (1938) considered S. bumelioides a synonym of $S$. myrtifolia, and he mentioned that the latter species is distributed in low mountains from Jujuy to Córdoba. We agree with Barkley (1957) and Muñoz (2000), however, that they are distinct. Schinus myrtifolia has unarmed branches (Fig. 5F,L, 6A,F,G) and tetramerous flowers (Fig. $5 \mathrm{~K}$ ), whereas $S$. bumelioides has conspicuously armed branches and pentamerous flowers. Schinus pilifera also may occur in the same area as S. myrtifolia, but is distinguished by the same characters as $S$. bumelioides. Although $S$. bumelioides and $S$. pilifera can have coincident distribution with $S$. myrtifolia, the former two species are distributed in pre-Puna, Puna, Chaco or dry inter-Andean valleys. Schinus areira, another species from arid vegetation, presents a distribution similar to $S$. myrtifolia, but the former species differs by having compound leaves (vs. simple leaves in the latter). Schinus myrtifolia has leaves that are broadly elliptic or oblong, rarely ovate with the margin often entire or sometimes entire on the proximal portion and crenate on the distal portion, and the base acute, rarely obtuse (Fig. $5 \mathrm{~F}, \mathrm{I}, \mathrm{J}, \mathrm{L})$. It can be confused with $S$. gracilipes where their distributions overlap in northwestern Argentina because sometimes S. myrtifolia has ovate leaves with the margin conspicuously crenate distally (Fig. 6F) similar to $S$. gracilipes. However, $S$. gracilipes has leaves that are ovate or ovate-lanceolate, with the margin consistently crenate, crenate-serrate or doubly-serrate (Fig. 3A,B,D). Schinus myrtifolia may also co-occur with $S$. obliqua, $S$. meyeri and $S$. venturii in areas of Tucumán-Bolivian forests from Bolivia and Argentina, but these three latter species clearly differ by having leaves that are ovate, ovate-lanceolate or lanceolate and pseudoracemes that are often branched at the base, sometimes as thyrsoids, cymes or solitary flowers (Fig. 3I,N, 9A,E) and pistillate flowers with larger pistils (1.2-1.5 mm, $1.4 \mathrm{~mm}$ and 1-1.4 mm long overall, respectively). In contrast, $S$. myrtifolia has unbranched pseudoracemes (Fig. 5F), leaves as mentioned above (Fig. 5F,I,J,L, 6E-G) and pistillate flowers with pistils of $0.8 \mathrm{~mm}$ long overall. 
7. Schinus obliqua Silva-Luz \& J.D. Mitch., sp. nov. - Type: Bolivia, depto. Tarija, prov. Burnet O'Connor, area de Los Canalitos, 55-60 km de Tarija hacia Entre Rios, 2050 m alt., 23 Nov 1996, J.R.I. Wood 11623 (holotype: LPB!).

Figures: 7 A, 9 A-G

Diagnosis. Shrubs 1.8-2 $\mathrm{m}$ tall, Schinus obliqua differs from all other species in section Myrtifolia by its markedly blade with basal width asymmetrical and its indumentum being densely clavate-glandular, hirsute or villous, on the veins of both surfaces. Schinus obliqua is similar to $S$. villosa because of its villous branches and hirsute or villous leaves, but it differs by the median internodes of its staminate inflorescences being 2.7-5 mm long (vs. 0.5-1.4 mm long in the latter). Schinus obliqua differs from $S$. villosa in its pistillate inflorescences being $10-30 \mathrm{~mm}$ long (vs. 5-7 mm long).

Description. Shrubs or tree, 1.8-4 m tall. Branches erect, unarmed, sparsely villous or clavate-glandular. Trichomes simple, barbellate or barbed and creamcolored or transparent, clavate-glandular and transparent or orange; erect, (slightly) sigmoid or straight, sometimes nutant or arcuate, 0.2-0.6 mm long on branches and leaves, and 0.1-0.3 mm long on inflorescences. Leaves not congested; petiole 4-10 $\mathrm{mm}$ long, canaliculate, densely villous or clavate-glandular on both surfaces; blade 3.5-9.3 x 2.1-4.9 cm, often ovate, sometimes lanceolate; apex obtuse, rounded; medially asymmetrical, basal insertion asymmetrical, basal width markedly asymmetrical, base obtuse, rounded or truncate; margin entire or distal portion crenate-serrate or twice-crenate, slightly revolute on proximal portion, undulate; chartaceous, sometimes coriaceous, dull; costal secondaries in 8-16 pairs, spacing irregular, course arcuate, angle smoothly increasing toward base; marginal secondary vein $0.08-0.09 \mathrm{~mm}$ in width, inconspicuous; tertiary veins visible; on abaxial side the midvein prominent proximally and prominulous distally, secondary veins prominulous or flat, tertiary veins flat, clavate-glandular, hirsute or villous, densely so on veins; on adaxial side the midvein prominent proximally and prominulous distally, secondary veins flat medially and impressed toward margin, tertiary veins impressed, clavate-glandular, hirsute or villous, densely on veins. Inflorescences axillary or terminal, villous or clavate-glandular; bracts dimorphic, smaller ones 0.4-0.8 x 0.4-0.5 mm, deltate, larger ones 2.5-6.5 x $1 \mathrm{~mm}$, obovate or oblanceolate, foliose; bracteoles 0.2-0.4 x 0.08-0.2 mm, lanceolate or ovate; bracts and bracteoles densely villous or hirsute on both surfaces; pedicel hirsute, villous or clavate-glandular, often bracteoles present on the pedicel; sepals pilose, densely hirsute or clavate-glandular on both surfaces; petals with midvein branching at apex 
and 1-3 cladodromous veins, glabrous; disk $0.4-0.7 \mathrm{~mm}$ tall and ca. $0.08-0.2 \mathrm{~mm}$ thick, sparsely hirsute on male flowers and glabrous on female flowers. Staminate inflorescences 14-48 mm long, flowers in pseudoracemes, often branched at base, sometimes thyrsoids, cymes or solitary, median internode $2.7-5 \mathrm{~mm}$ long. Staminate flowers with pedicel 3-8.1 mm long, the articulation not visible; sepals $0.8-1.3 \times 0.9$ $1.4 \mathrm{~mm}$, (broadly) oblong or ovate; petals (1.6-) 1.9-2.5 x (1-) 1.2-1.8 mm, (broadly) ovate or obovate, convex or concave, antesepalous and antepetalous stamens (1-) 1.4-1.5 and 0.8-1.2 mm long, respectively; anthers 0.4-0.6 mm long, ovate, oblong or lanceolate in dorsiventral view, (broadly) oblong in lateral view; pistillode 0.3-0.6 $\mathrm{mm}$ long. Pistillate inflorescences $10-30 \mathrm{~mm}$ long, flowers in pseudoracemes, median internode 1-2.9 mm long. Pistillate flowers with pedicel 2.7-6 mm long overall, the articulation not visible; sepals $0.7-0.9 \times 0.8-1 \mathrm{~mm}$, (broadly) ovate; petals 1.4-1.6 x 0.7-1.1 mm, oblong or ovate, concave; pistil 1.2-1.5 mm long overall, glabrous; ovary globose, laterally compressed, style 0.08-0.2 mm long; antesepalous and antepetalous staminodes $0.5-0.6 \mathrm{~mm}$ long and 0.3-0.5 mm long, respectively, anthers $0.3-0.5 \mathrm{~mm}$ long. Fruiting pedicel (1.5-) 2.5-5.2 mm long overall, the articulation not visible, villous or hirsute. Drupes 5.4-7 x 6.1-6.7 mm, red, globose, laterally compressed, sparsely hirsute or glabrescent.

Specimens examined. BOLIVIA. Tarija: Burnet O'Connor, Area de Los Canalitos, 55-60 km de Tarija, hacia Entre Ríos, 2050 m alt., 23 Nov 1996, J.R.I. Wood 11623, fl. (LPB); 2127'19"S, 6420'33”W, 2100 m alt., 12 Oct 2005, S.G. Beck \& D. Barrientos 31464, fl. (LPB, NY); ca. $70 \mathrm{~km}$ on road from Tarija to entre ríos, $21^{\circ} 26^{\prime} \mathrm{S}, 64^{\circ} 19^{\prime} \mathrm{W}, 2200 \mathrm{~m}$ alt., 20 Sept 1991, M. Kessler 3133, 3139, fl., fr. (LPB); ca. $6 \mathrm{~km}$ E of pass on Tarija-Entre Ríos road, $21^{\circ} 27^{\prime} \mathrm{S}, 64^{\circ} 26^{\prime} \mathrm{W}, 2300 \mathrm{~m}$ alt., 20 Sept 1991, M. Kessler 3163, fl. (LPB). Cercado, 54.9 km E of Tarija-Padcaya road, on road to Entre Ríos, $21^{\circ} 29^{\prime} \mathrm{S}, 64^{\circ} 20^{\prime} \mathrm{W}, 2050 \mathrm{~m}$ alt., 1 May 1983, J.C. Solomon 10327, fl. (LPB, MO).

Distribution. Restricted and endemic to south Bolivia, in Tarija department (Fig. 7A).

Ecology. Schinus obliqua occurs on steep slopes of Tucumán-Bolivian forest (Fig. 7A) associated with Polylepsis, Podocarpus and Alnus forests, between from $2050-2300 \mathrm{~m}$. It is also found in moisty shrubby vegetation, sometimes heavily disturbed. It is known to flower in May and Set-Nov, and fruit in Sept.

Conservation status. The IUCN threat status of $S$. obliqua was evaluated as Critically Endangered (CR) based on the extent of occurrence (EOO=38.267 $\mathrm{km}^{2}$ ) and as Endangered (EN) according to area of occupancy $\left(\mathrm{AOO}=20.000 \mathrm{~km}^{2}\right)$. The records of this species come only from sparse road network in south Bolivia, 
and the vegetation nearby these roads is disturbed mostly because of agriculture and cattle grazing, however vicinity areas, especially the Tariquía Flora and Fauna National Reserve hold substantially areas of montane cloud forests. Since the low collection densities seem to be related to fieldwork gap, we assign a preliminary IUCN threat status of Endangered (EN, A4).

Common name. None reported.

Discussion. Schinus obliqua is often misidentified as $S$. meyeri or $S$. myrtifolia. In fact, S. obliqua, S. meyeri, S. myrtifolia and S. venturii may occur in sympatry in the Tucumán-Bolivian forests of Tarija department. Schinus obliqua is readily separated from those species because of its remarkable leaves, which are medially asymmetrical and the basal width also asymmetrical, the basal shape rounded or truncate and the surface hirsute or villous on both surfaces (Fig. $9 A, D, E)$. Specimens from Cercado province have staminate flowers with smaller petals and sepals (1.6 $\times 1$ and $0.5 \times 0.6 \mathrm{~mm}$, respectively). Schinus obliqua also may occur sympatrically with populations of $S$. pilifera and $S$. areira (neither species treated in this taxonomic revision) but in ecotones between montane cloud forests and pre-Puna, Puna, dry inter-Andean valleys or Chaco. Both species are distinct from $S$. obliqua, as the latter has unarmed branches, simple leaves and tetramerous flowers (Fig. 9A-G), while they both have pentamerous flowers, besides $S$. pilifera has conspicuous armed branches and $S$. areira has compound leaves.

8. Schinus subtridentata (Kuntze) Silva-Luz, comb. nov. \& stat. nov. $\equiv$ Schinus huyngan var. subtridentata Kuntze, Revisio Generum Plantarum 3(3): 46. 1898, syn. nov. Schinus andina var. subtridentata (Kuntze) F.A. Barkley, Brittonia 5(2): 179. 1944, syn. nov. - Lectotype (designated here): Bolivia, Cochabamba, 26.III.1892, O. Kuntze s.n. (NY!).

Figures: 7 C, 8 I-P

Description. Shrubs, sometimes tree(lets), 0.3-4 m tall. Branches erect, unarmed, sometimes inconspicuously armed, sparsely hirsute or clavate-glandular. Trichomes simple and transparent or clavate-glandular and transparent or orange; erect, straight, 0.04-0.1 mm long on branches, leaves and inflorescences. Leaves not congested; petiole 1-5 mm long, semi-terete or slightly canaliculate, hirsute or clavate-glandular, sometimes pilose on both surfaces; blade 0.7-2.4 x 0.7-1.4 cm, (broadly) ovate, oblong or obovate, sometimes orbicular; apex obtuse, rounded or truncate; medially subsymmetrical, basal insertion (sub)symmetrical, basal width (sub)symmetrical, obtuse, sometimes acute, rounded or decurrent, rarely cordate; 
margin entire on proximal portion and (slightly) crenate on distal portion, flat or revolute, sparsely strigose or hirsute; coriaceous, dull, sometimes glossy; costal secondaries in 5-7 pairs, spacing often regular, course straight or arcuate, angle uniform, irregular or smoothly increasing toward base; marginal secondary vein 0.1 $0.2 \mathrm{~mm}$ in width, conspicuous; tertiary veins not visible; on abaxial side the midvein prominent, secondary veins flat, rarely prominulous or impressed, hirsute or densely clavate-glandular; on adaxial side the midvein flat or prominulous proximally and impressed distally, secondary veins impressed, hirsute or clavate-glandular, often conspicuous on midvein. Inflorescences axillary or terminal, clavate-glandular or puberulous; bracts dimorphic, smaller ones 0.3-0.8 x 0.5-1 mm, (broadly) deltate, larger ones $6 \times 5.5 \mathrm{~mm}$, foliose; bracteoles $0.2-0.4 \times 0.1-0.5 \mathrm{~mm}$, ovate or deltate; bracts and bracteoles sparsely pilose, puberulous or clavate-glandular on both surfaces; pedicel hirsute or clavate-glandular, bracteoles subtending pedicel; sepals puberulous or clavate-glandular on both surfaces, conspicuous on margin; petals with midvein branching at apex and 1-2 cladodromous secondary veins, essentially glabrous on both surfaces, rarely puberulous on margin; disk $0.3-0.4 \mathrm{~mm}$ tall and ca. $0.1 \mathrm{~mm}$ thick, glabrous. Staminate inflorescences $8-15 \mathrm{~mm}$ long, flowers in pseudoracemes, branched at base, sometimes densely branched distally, median internodes 1-2 mm long. Staminate flowers with pedicel 1.4-1.6 mm long overall, portion distal to articulation 0.5-0.6 mm long; sepals $0.3-0.7 \times 0.5-0.7 \mathrm{~mm}$, ovate or deltate; petals 1-1.7 $\times$ 0.8-1.3 mm, ovate or oblong; antesepalous and antepetalous stamens 0.8-1.1 and 0.6-1 mm long, respectively; anthers $0.3 \mathrm{~mm}$ long, (broadly) oblong or ovate in dorsiventral view, oblong in lateral view; pistillode 0.3-0.5 mm long. Pistillate inflorescences 6-16 mm long, flowers in lax pseudoracemes, median internodes 1-1.5 mm long. Pistillate flowers with pedicel 1-2 mm long overall, portion distal to articulation $0.5 \mathrm{~mm}$ long or the articulation not visible; sepals 0.4-0.6 $\times 0.6$ $0.7 \mathrm{~mm}$, ovate; petals 1.1-1.4 x 0.8-1 mm, ovate, concave; pistil 0.7-1.1 mm long overall, glabrous; ovary globose, laterally compressed, style $0.08 \mathrm{~mm}$ long; antesepalous and antepetalous staminodes $0.4 \mathrm{~mm}$ long and 0.3-0.4 mm long, respectively, anthers 0.1-0.2 $\mathrm{mm}$ long. Fruiting pedicel 2.3-2.5 $\mathrm{mm}$ long overall, the articulation not visible, puberulous or clavate-glandular. Drupes 5-5.2 x 5-6.3 mm, red or pink, globose or obliquely ovoid, laterally compressed, glabrous.

Specimens examined. BOLIVIA. Chuquisaca: Maragua, cercanias de Sucre, 18 $59^{\prime} 42^{\prime \prime}$ S, 65²5'09'W, 3062 m alt., 4 Aug 2007, M. Velayos et al. 11118, fl., fr. (LPB); Maragua, 3320 m alt., 23 Aug 1980, S.G. Beck 2, fl. (LPB, NY); Capilla de Chataquilla, camino hacia Chaunaca, 1859'30.0'S, 65²4'2'W, 3496 m alt., 25 May 2006, E. Cervantes et al. 13, fl. (HSB, MO); Sucre, sobre el camino $1 \mathrm{~km}$ antes 
de la división departamental entre Potosí y Sucre, 3100 m alt., 19 Sept 2006, I. Linneo et al. 774, fl. (MO, USZ); summit of Cerro Obispo, 3500 m alt., 30 Dec 1993, J.R.I. Wood 7794, fl. (LPB). Cochabamba: Arani, $49.3 \mathrm{~km} \mathrm{E}$ of the bridge over the río Pucará (at Punata), on the road to Santa Cruz, $17^{\circ} 26^{\prime} \mathrm{S}, 65^{\circ} 29^{\prime} \mathrm{W}, 3100-3300 \mathrm{~m}$ alt., 20 Oct 1985, J.C. Solomon 14444, fl. (LPB, MBM, MO). Carrasco, Incallajta

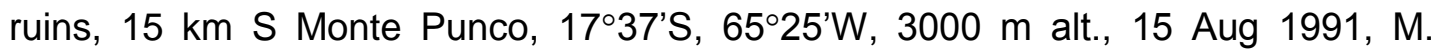
Kessler 2977, fl., fr. (LPB). Quillacollo, 60 km de Cochabamba, en dirección a Camino Cantón Sipe Sipe, comunidad de Choroko Exp. E-NE, 3900 m alt., 15 Dec 1988, M. Liberman 2300, fl. (LPB, MO, NY); Siberia-Copachuncho, a unos 155 km de la ciudad de Cochabamba, próximos al pueblito de Copachuncho, 1746’22”S, $65^{\circ} 2^{\prime} 21^{\prime \prime} \mathrm{W}, 2847 \mathrm{~m}$ alt., 22 Sept 2007, J. Teran et al. 1125, fl. (LPB, MO, NY); the road between Cochabamba and Santa Cruz, $107 \mathrm{~km}$ from Cochabamba, Geviñapamba, 17³4'S, 651’'W, 3100 m alt., 21 April 1987, J. Brandbyge 712, fl., fr. (LPB, MO); a 40 km de Epizana por la carretera que conduce a Santa Cruz, 3100 m alt., 26 Dec 1982, J.F. Casas 7790, fl., fr. (MO); quebrada de Zapata Rancho, camino viejo Cbba, 3200 m alt., 20 March 1991, I. Hensen 1906, fl. (LPB); Cercado, Pajcha, 17¹9'14"S, 6608'13'”W, 3340 m alt., 10 March 2004, E. Gutierrez et al. 696, sterile (BOLV, MO); 26 March 1892, O. Kuntze (NY [lectotype]). La Paz: 10.000 ped., 1890, A.M.B. Lectae 160, fl. (MO, NY); along the río Khatu from the footbridge of the Cambillaya-Cochabambita trail to the mouth of the río Jokho Pampa, ca. $4 \mathrm{~km} \mathrm{~W}$ of Inquisivi, 165 'S, 67'10'W, $2450 \mathrm{~m}$ alt., 18 Jan 1989, M. Lewis 35118, sterile (LPB, MO, NY). Charazani-Tal, 3150 m alt., 30 March 1980, T. Feuerer 4019, fr. (NY); along the road ca. 1-2 km W of Inquivisi, $16^{\circ} 54^{\prime} \mathrm{S}, 67^{\circ} 09^{\prime} \mathrm{W}$, 2900 m alt., 13 March 1989, M. Lewis 35361, fl. (LPB, MO, NY). Inquivisi, Cerro Aguada, about $5 \mathrm{~km}$ SSW from Comunidad Khora, $24 \mathrm{~km} \mathrm{~N}$ of Choquetanga, 2750 m alt., 22 Nov 1991, M. Lewis 40623, fr. (LPB, MO, NY); Quime 7 kms, hacia Caxata, 3420 m alt., 19 Feb 1981, S.G. Beck 4376, fl. (LPB, NY). Potosí: Charcas, 20 June 1993, G. Torrico \& C. Peca 533, fl., fr. (LPB, NY). Chayanta, comunidad de Pajri Cuchu, próximo a Ranchos, 3780 m alt., 12 March 1993, G.Torrico \& C. Peca 120, fl., fr. (LPB, NY).

Distribution. Endemic to Bolivia, this is a relatively widespread distributed and common species in that country, occurring from La Paz and Cochabamba departments toward central-south in Chuquisaca and Potosí departments (Fig. 7C).

Ecology. Schinus subtridentata occurs on humid rocky slopes of pre-Puna, Puna or dry inter-Andean valleys, associated to Polylepis forests, between 2450 $3900 \mathrm{~m}$. This species as $S$. microphylla have contrasting distribution regarding to 
other species of this section, since they do not occur in montane cloud forests. It is known to flower in Feb-June, Aug-Oct and Dec, and fruit in March-April, June, Aug and Nov-Dec.

Conservation status. The IUCN threat status of $S$. subtridentata was evaluated as Near Threatened (NT) based on the extent of occurrence $\left(E O O=42,858.507 \mathrm{~km}^{2}\right.$ ) and as Endangered (EN) according to area of occupancy $\left(A O O=52.000 \mathrm{~km}^{2}\right)$. Although some collections are from Cochabamba, an area under habitat loss to development, populations are also found in less populated areas of south Bolivia and probably under less human pressure. The numerous available collections suggest that $S$. subtridentata is a common species, and since it occurs on steep slopes, in areas where the access can be difficult, the collection density may be underestimated. Overall, the extent of occurrence likely encompasses suitable habitat for this species, thus we assign the preliminary IUCN threat status of Near Threatened (NT).

Common names. Chirimolle (Spanish); huislulu, suilulu, sip'l nuko, wislulu (Quechua)

Discussion. According to the morphological analysis, most specimens previously identified as $S$. andina (here considered as illegimate name and synonym of $S$. microphylla) match the type material of Schinus andina var. subtridentata (Kuntze) F.A.Barkley. This combination made by Barkley (1944) was based on Schinus huyngan Kuntze var. subtridentata Kuntze. For the latter variety, Kuntze (1898) cited two collections, a specimen collected by Hieronymus in Sierra Achala, Argentina, and a specimen collected by Kuntze in Cochabamba, Bolivia, both specimens without number of collection. There are two specimens housed at the NY herbarium which were annotated by Kuntze and could be assigned to the specimens before mentioned. The specimen from Bolivia, collected by Kuntze corresponds to $S$. subtridentata, whereas the one from Sierra Achala, in Cordoba, Argentina, collected by Hieronymus, even though it is very fragmented could probably be assigned to $S$. praecox (Griseb.) Speg. or $S$. pilifera (neither species treated in this taxonomic revision), because of the conspicuously armed branches. Thus, we chose the specimen from Cochabamba as the lectotype for Schinus huyngan var. subtridentata.

Schinus subtridentata can be found in sympatry with $S$. congestiflora in Cochabamba. Although both species have similar inflorescence length, the former species usually has staminate flowers with shorter pedicels 1.4-1.6 mm long (vs. 1.3-2.5 mm long in $S$. congestiflora) and pistillate inflorescences with median internodes $1-1.5 \mathrm{~mm}$ long (vs. 0.5-1 mm long in $S$. congestiflora). Moreover, $S$. 

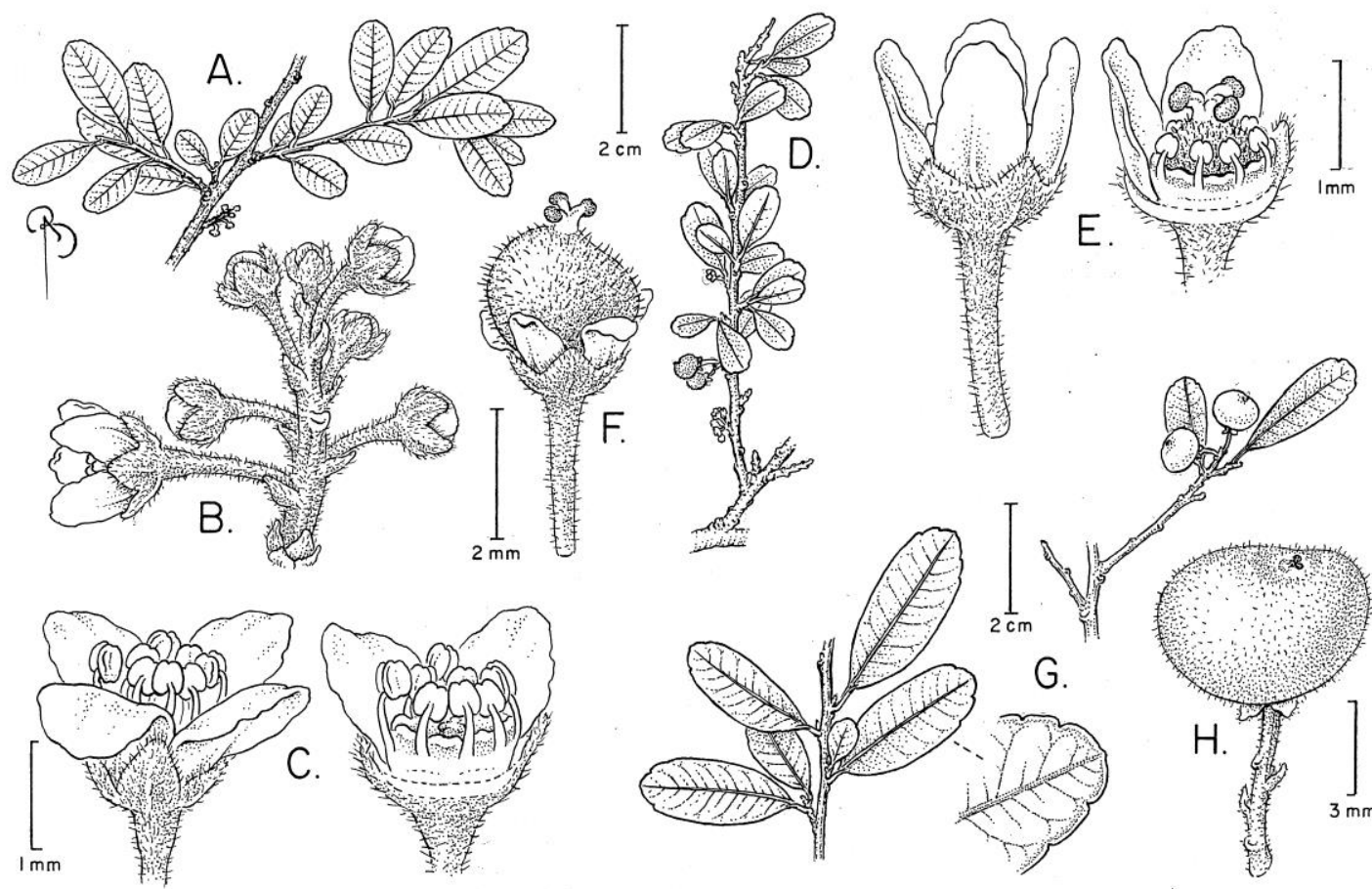

镬

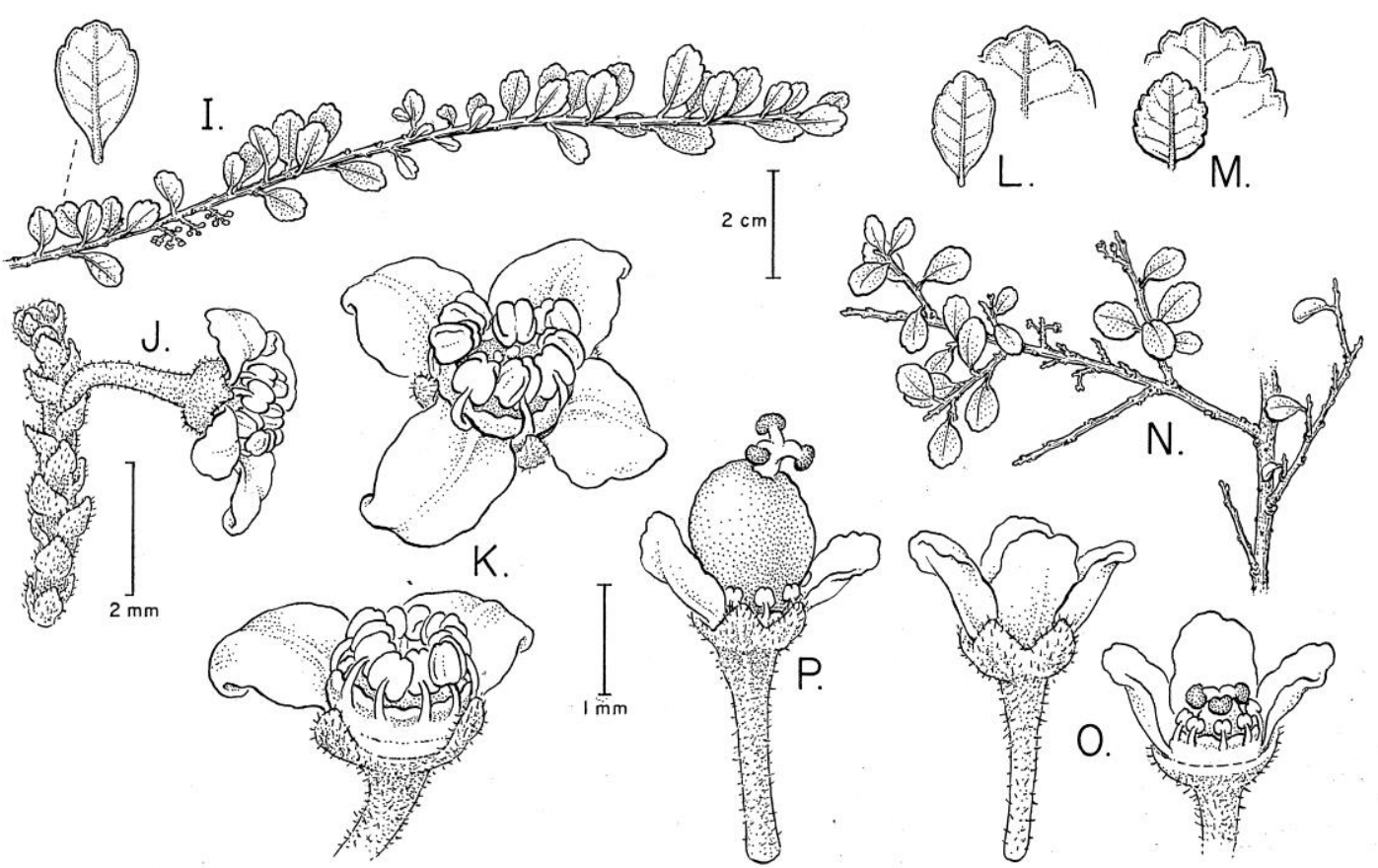

Fig. 8. A-H: Schinus tarijensis. A. Flowering branchlet; B. Staminate inflorescence; C. Staminate flower plus detail of the flower with two petals and one sepal removed; D. Flowering and fruiting branchlet; E. Pistillate flower with two petals and two sepals removed; F. Immature fruit in development; G. Sterile branchlet plus detail of the venation and margin on distal portion of leaf (inset); H. Fruiting branchlet plus detail of the fruit indumentum. I-P: Schinus subtridentata. I. Flowering branchlet plus detail of the leaf (inset); J. Staminate inflorescence; K. Top view of the staminate flower plus detail of the flower with two petals removed; L-M. Leaf plus detail of the venation and margin on distal portion; N. Flowering branchlet; $\mathbf{O}$. Pistillate flower plus detail of the flower with one petal and two sepals removed; P. Immature fruit in development. 
subtridentata has the leaves essentially coriaceous (vs. chartaceous), costal secondary veins with spacing usually regular (vs. usually irregular - Fig. 2A,D-E), tertiary veins not visible (Fig. 8I,L,M,N; vs. barely visible), and both sides of leaves essentially hirsute or densely clavate-glandular (vs. both sides of leaves essentially puberulous or clavate-glandular, rarely hirsute on abaxial surface). Populations of $S$. subtridentata and S. minutiflora can occur in Chuquisaca and Cochabamba but the former species has staminate inflorescences 8-15 mm long (Fig. 8I,J) and dimorphic bracts, whereas the latter species has staminate inflorescences 6-8 mm long (Fig. $2 \mathrm{H}, \mathrm{J})$ and monomorphic bracts. Specimens of $S$. subtridentata distributed in Chuquisaca have distinct (broadly) ovate leaves which are densely hirsute abaxially (Fig. 8M). Schinus subtridentata and S. microphylla occur in sympatry, but the former species has leaves often dull (vs. often glossy - Fig. 4D-E), secondary vein angle uniform, irregular or smoothly increasing toward base (Fig. 8I,L-M; vs. smoothly decreasing toward base - Fig. 5A-B), and staminate and pistillate inflorescences with the median internodes $1-2 \mathrm{~mm}$ long and $1-1.5 \mathrm{~mm}$, respectively (vs. 1.7-3.5 $\mathrm{mm}$ and $1.7 \mathrm{~mm}$, respectively). Schinus subtridentata may also co-occur with S. pilifera, S. pearcei and S. areira, however S. subtridentata differs by having simple leaves and tetramerous flowers, whereas $S$. pilifera has pentamerous flowers, S. pearcei bears dissected leaves and paniculate inflorescences, and S. areira has compound leaves.

9. Schinus tarijensis Silva-Luz \& J.D. Mitch., sp. nov. - Type: Bolivia, Tarija, cuenca del río Camacho, río Lanurejoy, 2540 m alt., Exp. N., Incl. 35-40, frente al la comunidad de Camacho, 20 Dec 1987, M. Liberman \& S.G. Beck 1563 (holotype: LPB!; isotypes: $M, N Y !)$.

Figures: 7 A, 8 A-H

Diagnosis. Shrubs, sometimes tree(lets) $1-4 \mathrm{~m}$ tall, similar to $S$. congestiflora because both have chartaceous obovate leaves with overlapping dimensions of $1.4-3 \times 0.9-1.2 \mathrm{~cm}$ and $1.5-3(-3.5) \times 1-1.6(-1.9-2.2) \mathrm{cm}$ in the latter, respectively. Schinus tarijensis differs from $S$. congestiflora by its smaller, lax staminate inflorescences 4-7 mm long (vs. congested staminate inflorescences 5-13 $\mathrm{mm}$ long in the latter). Schinus tarijensis also differs from $S$. congestiflora by its pistil being densely hirsute or clavate-glandular and its densely hirsute or clavateglandular, sometimes glabrescent fruits, 6-7 x 6.2-8 mm (vs. S. congestiflora with glabrous pistil and fruits, $4-5.5 \times 4.5-6.4 \mathrm{~mm}$ ). Schinus tarijensis is similar to $S$. microphylla because of its congested leaves, however, $S$. tarijensis differs from the 
latter by its larger leaves, $1.4-3 \times 0.9-1.2 \mathrm{~cm}$ and oblong staminate petals (vs. leaves, $0.9-1.7 \times 0.6-1 \mathrm{~cm}$ and ovate staminate petals in $S$. microphylla).

Description. Shrubs, sometimes tree(lets), 1-4 m tall. Branches erect, unarmed, hirsute, tomentose or clavate-glandular. Trichomes simple, barbellate and transparent or clavate-glandular and transparent or orangish; erect or appressed, straight or arcuate, sometimes nutant, $0.2 \mathrm{~mm}$ long on branches, $0.03 \mathrm{~mm}$ on leaves, $0.08 \mathrm{~mm}$ on inflorescences and $0.08-0.2 \mathrm{~mm}$ on fruits. Leaves often congested; petiole 1-5 mm long, canaliculate, on abaxial surface puberulous, on adaxial surface densely pilose, puberulous or clavate-glandular; blade 1.4-3 x 0.9$1.2 \mathrm{~cm}$, obovate; apex obtuse, rounded; medially (sub)symmetrical, basal insertion symmetrical, base width (sub)symmetrical, acute, cuneate; margin often entire on proximal portion and crenate on distal portion, slightly revolute, strigose or pilose; texture chartaceous, dull; costal secondaries in 8-9 pairs, spacing often irregular, course straight or arcuate, angle uniform or smoothly decreasing toward base; marginal secondary vein $0.04-0.1 \mathrm{~mm}$ in width, inconspicuous; tertiary veins sometimes visible; on abaxial side the midvein flat or flat proximally and slightly impressed distally, secondary veins flat or slightly impressed on abaxial surface, tertiary veins flat, strigose or pilose on midvein, especially on proximal portion, rest of surface clavate-glandular; on adaxial side the midvein prominulous on proximal portion and flat toward apex, secondary veins impressed, tertiary veins flat, strigose or pilose on midvein, especially on proximal portion, rest of surface clavateglandular. Inflorescences axillary, clavate-glandular or pilose; bracts monomorphic, 0.6-0.8 x 0.3-0.5 mm, (broadly) deltate; bracteoles 0.3-0.4 x 0.2-0.3 mm, usually oblong, sometimes ovate; bracts and bracteoles clavate-glandular or pilose on both surfaces, conspicuous on margin; pedicel densely pilose, hirsute or clavateglandular, bracteoles subtending pedicel; sepals hirsute, pilose or sparsely clavateglandular on abaxial surface and margin, glabrous on adaxial surface; petals with midvein branching at apex and 1 cladodromous secondary vein, essentially glabrous; disk 0.3-0.5 mm tall and ca. 0.08-0.2 mm thick, glabrous. Staminate inflorescences 4-7 mm long, flowers in lax pseudoracemes, median internodes 1.1$1.4 \mathrm{~mm}$ long. Staminate flowers with pedicel $3 \mathrm{~mm}$ long overall, portion distal to articulation $1.2 \mathrm{~mm}$ long; sepals 0.9-1 x 0.8-0.9 mm, (broadly) ovate; petals $1.7 \times 1.5$ $\mathrm{mm}$, (broadly) oblong, convex; antesepalous and antepetalous stamens 1.3 and 0.8 $\mathrm{mm}$ long, respectively; anthers 0.4-0.5 mm long, (broadly) oblong in dorsiventral and lateral views; pistillode $0.8 \mathrm{~mm}$ long. Pistillate inflorescences $6-8 \mathrm{~mm}$ long, flowers in lax pseudoracemes, median internodes 1-1.1 mm long. Pistillate flowers with pedicel 1.6-2.7 mm long overall, portion distal to articulation $0.4-1 \mathrm{~mm}$ long; sepals 
0.4-0.8 x 0.5-0.8 mm, ovate; petals 1.4-1.6 x 0.8-1.1 mm, oblong or ovate, concave; pistil 1.4-1.5 mm long overall, densely hirsute or clavate-glandular; ovary globose, style $0.1 \mathrm{~mm}$ long; antesepalous and antepetalous staminodes $0.4-1 \mathrm{~mm}$ long and 0.3-0.5 mm long, respectively, anthers $0.3 \mathrm{~mm}$ long; Fruiting pedicel $2-3 \mathrm{~mm}$ long overall, portion distal to articulation $1.2 \mathrm{~mm}$ long, pilose, puberulous or clavateglandular. Drupes 6-7 x 6.2-8 mm, red or pink, obliquely globose or ovoid, laterally compressed, conspicuous hirsute or clavate-glandular, sometimes glabrescent.

Specimens examined. BOLIVIA. Tarija: Aniceto Arce, Padcaya, reserva Nacional de Flora y Fauna Tariquía, bajando el cerro Alisos, $2550 \mathrm{~m}$ alt., 11 Nov 2004, M. Serrano et al. 5050, fl., fr. (HSB, MO); cuenca del río Camacho, río Lanurejoy, frente al la comunidad de Camacho, $2540 \mathrm{~m}$ alt., 20 Dec 1987, M. Liberman \& G. Beck 1563, fl., fr. (LPB [holotype], M, NY [isotypes]); Padcaya, reserva Nacional de Flora y Fauna Tariquía, bajando el cerro Alisos, 2550 m alt., 11 Nov 2004, M. Serrano et al. 5055, fl. (HSB, MO); El Carmen, 2201'39’'S, 6450'16’'W, 2650 m alt., 11 Feb 2006, F. Zenteno et al. 3657, fr. (LPB, NY, TA). José María Avilés, El Carmen, Huayco Hondo, 2201'28'S, 6450’07'W, 2550 m alt., 11 Feb 2006, S. Gallegos et al. 354, fr. (LPB, NY); El Carmen, Huayco Hondo,

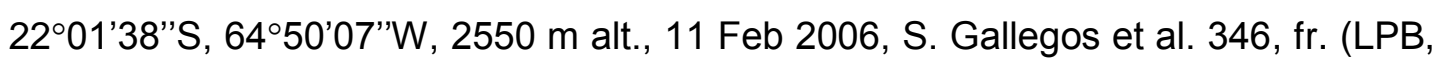
NY); El Carmen, Huayco Hondo, 22॰01'38'S, 6450'07'W, 2550 m alt., 11 Feb 2006, S. Gallegos et al. 367, sterile (LPB, NY); Calderillo, 3300 m alt., 7 Jan 1904, K. Fiebrig 2477, fl. (MO).

Distribution. Restricted and endemic to south Bolivia, in Tarija Department (Fig. 7A).

Ecology. Schinus tarijensis occurs in shrubby areas of Tucumán-Bolivian forests (Fig. 7A) associated with Alnus and Polylepis forests, between 2540-3300 m. It is known to flower in Nov-Jan, and fruit in Nov-Dec and Feb.

Conservation status. The IUCN threat status of $S$. tarijensis was evaluated as Critically Endangered $(\mathrm{CR})$ based on the extent of occurrence $\left(E O O=5.503 \mathrm{~km}^{2}\right)$ and as Endangered (EN) according to area of occupancy $\left(A O O=12.000 \mathrm{~km}^{2}\right)$. Schinus tarijensis is known from a few records, most of them from Tariquía Flora and Fauna National Reserve. Since its area of occurrence is a relatively large protected area in Bolivia, and low collection densities may be related to fieldwork gap, we assign a preliminary IUCN threat status of Endangered (EN, A4).

Common name. None reported

Discussion. Schinus tarijensis is very distinct from other species of $S$. sect. Myrtifolia because of its usually congested leaves (fig. 8D), flowers with pistil 
conspicuously densely hirsute or clavate-glandular (Fig. 8E-F), the fruits relatively large $(6-7 \times 6.2-8 \mathrm{~mm})$ and conspicuously hirsute (Fig. $8 \mathrm{H})$ or sometimes glabrescent. Schinus meyeri and $S$. venturii occur in the same areas of TucumánBolivian forests distributed as $S$. tarijensis, and the new species may also co-occur in sympatry with $S$. pilifera and $S$. areira (neither species treated in this taxonomic revision) in ecotones between montane cloud forests and pre-Puna, Puna, dry interAndean valleys or Chaco. Schinus pilifera differs from $S$. tarijensis by having armed branches, and S. areira has compound leaves (vs. unarmed branches and simple leaves in S. tarijensis).

10. Schinus venturii F.A. Barkley, Brittonia 5(2): 179. 1944. - Type: Bolivia, Bermejo, 27 Nov 1903, K. Fiebrig 2291 (holotype: MO!; isotypes: LIL [photo]!, US!).

Figures: 3 M-R, 7 B

Description. Tree(lets) or shrubs, 2.5-5 m tall. Branches prostrate unarmed, puberulous, sparsely clavate-glandular or glabrous. Trichomes simple and transparent or clavate-glandular and transparent or orangish-red; erect or appressed, straight, $0.03-0.06 \mathrm{~mm}$ long on branches, $0.1 \mathrm{~mm}$ long on leaves and 0.03-0.06 mm long on inflorescences. Leaves not congested; petiole 3-15 mm long, (slightly) canaliculate or semi-terete, puberulous or clavate-glandular on both surfaces; blade 3.5-5.7 x 1.7-2.5 cm, ovate or ovate-lanceolate; apex obtuse, rarely acute, rounded, sometimes straight; medially (sub)symmetrical, basal insertion (sub)symmetrical, basal width symmetrical or asymmetrical, base obtuse, base decurrent, sometimes rounded; margin entire or entire on proximal portion and crenate, crenate-serrate or erose on distal portion, slightly revolute, puberulous on proximal portion; often chartaceous, dull; costal secondaries in 11-14 pairs, spacing irregular, course arcuate, angle irregular; marginal secondary vein 0.04-0.1 mm in width, tertiary veins inconspicuous; on abaxial side the midvein prominent proximally and prominulous distally, secondary veins flat or prominulous, tertiary veins flat, clavate-glandular; on adaxial side the midvein prominent or prominulous on proximal portion and flat toward apex, secondary veins flat medially and conspicuous impressed toward margin, tertiary veins impressed, puberulous on midvein, rest of surface clavate-glandular. Inflorescences axillary or terminal, puberulous or sparsely clavate-glandular; bracts dimorphic, smaller ones 0.3-1.3 (-2) x 0.6-0.9 mm, (broadly) deltate or ovate, larger ones 1.5-3.6 x 2-2.8 mm, ovate, foliose; bracteoles $0.2-0.6 \times 0.2-0.3 \mathrm{~mm}$, ovate; bracts and bracteoles pilose, puberulous or sparsely 
clavate-glandular on both surfaces, sometimes only on margin; pedicel puberulous or clavate-glandular, sometimes bracteoles present on the pedicel; sepals puberulous or clavate-glandular, sometimes glabrous on both surfaces, puberulous on margin; petals with midvein sometimes branching at apex and 1-2 cladodromous secondary veins, glabrous; disk 0.3-0.6 mm tall and ca. $0.1 \mathrm{~mm}$ thick, glabrous. Staminate inflorescences 8-30 $\mathrm{mm}$ long, flowers in congested pseudoracemes, often branched at base, rarely solitary, median internodes 1.3-2.7 mm long. Staminate flowers with pedicel 1.7-3.5 mm long overall, the articulation not visible; sepals 0.7-1.1 x 0.6-1.1 mm, (broadly) ovate; petals 1.7-2.3 x 1.3-1.5 mm, ovate, obovate or oblong, concave; antesepalous and antepetalous stamens 1.2-1.5 and 1$1.2 \mathrm{~mm}$ long, respectively; anthers $0.4-0.6 \mathrm{~mm}$ long, ovate or (broadly) oblong in dorsiventral view, oblong in lateral view; pistillode $0.3-0.5 \mathrm{~mm}$ long. Pistillate inflorescences $12-35 \mathrm{~mm}$ long, flowers in lax pseudoracemes, median internodes 1.4-3.2 mm long. Pistillate flowers with pedicel 2.6-5.7 $\mathrm{mm}$ long overall, the articulation not visible; sepals $0.6-1 \times 0.8-1 \mathrm{~mm}$, (broadly) ovate or deltate, conspicuous concave; petals 1.4-2 x 0.6-1.2 mm, ovate, obovate or oblong, concave; pistil 1-1.4 mm long overall, glabrous; ovary globose, laterally compressed, style $0.2 \mathrm{~mm}$ long; antesepalous and antepetalous staminodes $0.5-0.8$ $\mathrm{mm}$ long and 0.4-0.6 mm long, respectively, anthers 0.2-0.4 mm long. Fruiting pedicel 3-5 mm long overall, the articulation not visible, puberulous or clavateglandular. Drupes 5.2-6.5 × 6.1-6.5 mm, pink or red, obliquely ovoid, laterally compressed, sparsely hirsute or glabrescent.

Specimens examined. ARGENTINA. Jujuy: Ledesma, Abra de Las Cañas, 9 April 1971, P.R. Legname \& A.R. Cuezzo 7944 (LIL, US). Salta: Orán, cordillera oriental, sierra de Zenta, entre Trancas y San Andrés, $23^{\circ} 05^{\prime} \mathrm{S}, 64^{\circ} 52^{\prime} \mathrm{W}, 2200 \mathrm{~m}$ alt., 21 April 1998, A. Schinini et al. 34717, fl. (CTES, GH, NY). Santa Victoria, Los Toldos, Guaico Grande, 1850 m alt., 19 Aug 1971, F. Vervoost \& P.R. Legname 4492, fl. (LIL, NY). BOLIVIA. Tarija: Aniceto Arce, Padcaya, Cantón Emborozú, Reserva Natural Alarachi, Pendiente Superior, Cerro Los Tejerinas, 22 11 '56”'S, 64³6'26'W, $1960 \mathrm{~m}$ alt., 17 Sep 2004, M. Serrano et al. 4865, fl. (MO, USZ); comunidad Guayavillas, $23.8 \mathrm{~km} S$ of Padcaya on road to Bermejo, $21^{\circ} 59^{\prime} \mathrm{S}$, 6440'W, 2100 m alt., 5 May 1983, J.C. Solomon 10481, fl. (MO); Padcaya, Reserva Nacional de Flora y Fauna Tariquía, subeindo la Escalera, vertiente W, cerro Alisos, 2494 m alt., 27 Nov 2004, M. Serrano \& J. Villalobos 5347, fl., fr. (HSB, MO, NY); Bermejo, 27 Nov 1903, K. Fiebrig 2291 (MO [holotype], LIL, US [isotypes]). Burnet O'Connor, $21.1 \mathrm{~km}$ on road to Entre Ríos, $21^{\circ} 27^{\prime} \mathrm{S}, 64^{\circ} 20^{\prime} \mathrm{W}, 1900 \mathrm{~m}$ alt., 1 Oct 1983, J.C. Solomon 10927, fl. (LPB, MO, NY); sobre la carretera hacia la 


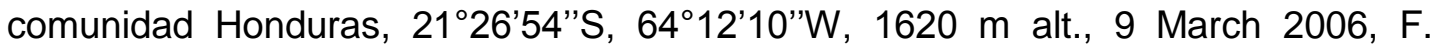

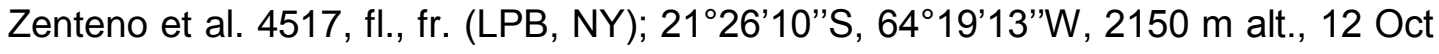
2005, S.G. Beck \& D. Barrientos 31470, fl. (LPB, NY); 10.8 km W of Narvaez

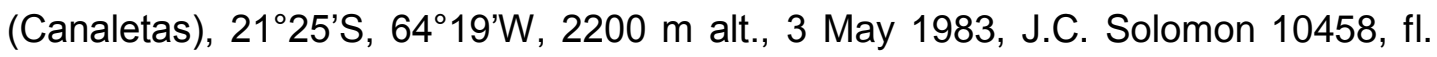
(MO, NY). Cercado, Tarija, 25 km NW, Rincon de La Victoria, $2340 \mathrm{~m}$ alt., 23 March 1979, S.G. Beck 795, sterile (MO).

Distribution. Restricted species to south Bolivia, in Tarija Department, and with scattered populations in northwestern Argentina, in Salta and Jujuy provinces (Fig. 7B).

Ecology. Schinus venturii occurs in Tucumán-Bolivian forests (Fig. 7B) associated with Podocarpus and Alnus forests and also in ecotones between montane cloud forests and pre-Puna, Puna or dry inter-Andean valleys, between 1620-2494 m alt. It is known to flower in March-May and Aug-Nov, and fruit in March and Nov.

Conservation status. The IUCN threat status of $S$. venturii was evaluated as Vulnerable (VU) based on the extent of occurrence $\left(E O O=6,440.957 \mathrm{~km}^{2}\right)$ and as Endangered $(E N)$ according to area of occupancy $\left(A O O=40.000 \mathrm{~km}^{2}\right)$. Most of the S. venturii collections are from the Tariquía Flora and Fauna National Reserve, in sparse road network in Bolivia, and also from vicinity areas of the Calilegua National Park. Overall, this species occurs within a large protected area in Bolivia, and low collection densities in the montane cloud forests are probably due either to the difficulty to access them or to fieldwork gap. Also, the extension of occurrence likely encompasses suitable habitat for this species, thus we assign the preliminary IUCN threat status of Vulnerable (VU, A4).

Common name. Not reported

Discussion. Schinus venturii occurs in the same geographical area as $S$. meyeri, but differs by its leaves often chartaceous (vs. membranaceous) and the secondary veins flat or prominulous medially and conspicuously impressed toward margin (vs. secondary veins sometimes consistently flat). The tertiary veins of $S$. venturii are inconspicuous and less branched than $S$. meyeri, which has the tertiary veins conspicuously branched. Additionally, Schinus venturii has the petiole often semi-terete (vs. canaliculate), staminate inflorescences congested (Fig. 3N; vs. laxFig. 3I) with median internodes 1.3-2.7 mm long (vs. 2.1-5 mm long) and petals with the midvein sometimes branching at apex (vs. midvein branching from the median portion toward the distal portion). Schinus venturii may be found sympatrically in the Tucumán-Bolivian forest with S. obliqua, S. gracilipes, S. myrtifolia and S. tarijensis. The former species has leaf shape (Fig. 3M-N) similar to $S$. obliqua (Fig. 9A,D-E) 
and S. gracilipes (Fig. 3A-B,D) but differs by the margin fully entire or entire on the proximal portion and crenate, crenate-serrate, or erose on distal portion and the flower pedicel apparently not articulated (vs. fully crenate, crenate-serrate, twiceserrate or erose and the flower pedicel articulated in S. gracilipes). Schinus venturii has leaves medially (sub)symmetrical, the basal width symmetrical or asymmetrical and the secondary vein angle irregular, whereas $S$. obliqua has leaves medially and the basal width asymmetrical (Fig. 9D) and the secondary veins smoothly increasing proximally. Schinus venturii is distinct from $S$. myrtifolia because the former's leaves are ovate or ovate-lanceolate (vs. leaves broadly elliptic or oblong, rarely ovate, Fig. $5 \mathrm{~F}, \mathrm{I}, \mathrm{J}, \mathrm{L})$. Schinus venturii can be differentiated from $S$. tarijensis because the former species has leaves as mentioned before and the pistil glabrous (Fig. 3R), whereas the latter has obovate and often congested leaves (Fig. 8A,D), and the pistil densely hirsute or clavate glandular (Fig. 8E-F). Schinus venturii can also co-occur with $S$. pilifera, $S$. bumelioides and $S$. areira (these species not treated in this taxonomic revision) in ecotones between montane cloud forests and pre-Puna, dry interAndean valleys or Chaco. Schinus pilifera and $S$. bumelioides differ from $S$. meyeri because of their armed branches, and $S$. areira differs by having compound leaves (vs. unarmed branches and simple leaves in S. meyeri).

11. Schinus villosa Silva-Luz \& J.D. Mitch., sp. nov. - Type: Bolivia, Prov. Belisario Boeto, c. $5 \mathrm{~km} \mathrm{~S}$ of Nuevo Mundo at summit of road to Villa Serrano, $2300 \mathrm{~m}$ alt., 18 Oct 1997, J.R.I. Wood 12708 (holotype: LPB!).

Figures: 7 B, 9 H-M

Diagnosis. Shrubs or tree(lets), 1.8-6 m tall., Schinus villosa is similar to $S$. obliqua because of its villous indumentum and cream trichomes. Schinus villosa differs from $S$. obliqua in its pistillate flowers with pedicels being 1.6-2.1 mm long overall (vs. pistillate flowers with pedicels $2.7-6 \mathrm{~mm}$ long overall in the latter).

Description. Shrubs or tree(lets), 1.8-6 m tall. Branches erect, unarmed, villous. Trichomes simple, barbellate or bulbous and cream-colored or clavateglandular and transparent or orange; erect, sigmoid or straight, 0.2-0.8 mm long on branches, (0.1-) 0.2-0.5 mm long on leaves and inflorescences. Leaves not congested; petiole 1-5 mm long, canaliculate, villous on both surfaces; blade 2.2-4.5 x 1-2.3 cm, often ovate or ovate-lanceolate, sometimes oblong or elliptic; apex obtuse, rarely acute, rounded, sometimes truncate or straighr; medially (sub)symmetrical, basal insertion symmetrical, basal width asymmetrical, base 
acute or obtuse, cuneate or decurrent; margin often entire on proximal portion and crenate or crenate-serrate on distal portion, sometimes entire or erose, conspicuous revolute; chartaceous, dull; costal secondaries in 6-12 pairs, spacing irregular, course arcuate, angle uniform or smoothly increasing toward base, marginal secondary vein $0.06-0.09 \mathrm{~mm}$ in width, inconspicuous; tertiary veins inconspicuous; on abaxial side the midvein prominent, secondary veins prominulous or flat villous, tertiary veins flat, hirsute or clavate-glandular; on adaxial side the midvein obscurely prominent proximally and flat or impressed distally, secondary veins conspicuously impressed, tertiary veins flat and villous, hirsute or clavate-glandular, densely or sparsely so on midvein. Inflorescences axillary or terminal, sparsely pilose or clavate-glandular; bracts dimorphic, smaller ones 0.3-0.7 $\times$ 0.5-0.8 mm, deltate; bracteoles 0.2-0.4 $\times$ 0.1-0.2 mm, lanceolate or (narrowly) ovate; bracts and bracteoles villous abaxially, glabrous adaxially; pedicel hirsute on staminate flowers and sparsely tomentose, hirsute, puberulous or clavate-glandular on pistillate flowers, bracteoles subtending pedicel; sepals tomentose, hirsute, puberulous or clavate-glandular, densely on margin; petals with midvein branching at apex and 1-3 cladodromous secondary veins, pilose on midvein and margin, rest of surface sparsely tomentose or glabrous; disk yellow, 0.3-0.6 mm tall and ca. 0.08-0.1 mm thick, glabrous or sparsely hirsute. Staminate inflorescences $9-45 \mathrm{~mm}$ long, flowers in congested pseudoracemes, often branched at base, median internodes 0.5-1.4 $\mathrm{mm}$ long. Staminate flowers with pedicel 1.3-3.8 $\mathrm{mm}$ long, the articulation not visible; sepals $0.5-1 \times 0.6-0.8 \mathrm{~mm}$, ovate; petals $1.6-2.2 \times 1-1.4 \mathrm{~mm}$, ovate or obovate, concave; antesepalous and antepetalous stamens 1-1.6 and (0.7-) 1-1.3 $\mathrm{mm}$ long, respectively; anthers 0.4-0.5 mm long, ovate in dorsiventral view, (broadly) oblong in lateral view; pistillode $0.3-0.5 \mathrm{~mm}$ long. Pistillate inflorescences 5-7 cm long, flowers in lax pseudoracemes, median internodes 0.6-1 mm long. Pistillate flowers with pedicel 1.6-2.1 mm long overall, portion distal to articulation $0.8 \mathrm{~mm}$ long; sepals $0.5-0.9 \times 0.4-0.9 \mathrm{~mm}$, ovate; petals $1.1-1.5 \times 0.8-1.2 \mathrm{~mm}$, ovate or obovate, concave; pistil 0.8-1.1 mm long overall, glabrous; ovary globose, laterally compressed, style 0.08-0.1 mm long; antesepalous and antepetalous staminodes 0.4-0.7 mm long and 0.3-0.6 mm long, respectively, anthers 0.2-0.3 mm long. Fruiting pedicel $1.8-2 \mathrm{~mm}$ long overall, portion distal to articulation $1 \mathrm{~mm}$ long or the articulation not visible, sparsely pilose, puberulous or clavate-glandular. Drupes 4.2-5.5 x 4.8-6 mm, red, pink or light purple, obliquely globose or ovoid, laterally compressed, glabrous.

Specimens examined. BOLIVIA. Chuquisaca: Belisario Boeto, c. $5 \mathrm{~km} \mathrm{~S}$ of Nuevo Mundo at summit of road to Villa Serrano, $2300 \mathrm{~m}$ alt., 18 Oct 1997, J.R.I. 
Wood 12708, fl., fr. (LPB [holotype]); comunidad Huerta Mayu, $3 \mathrm{~km}$ al SW de la localidad de Villa Serrano, 2200 m alt., 27 Feb 1994, M. Serrano 656, fl. (NY); ciudad Muyu Monte, 25 km al NE de Villa Serrano, 2650 m alt., 4 Jul 1993, J. Teran 540, fl., fr. (LPB, NY); 22 km en el camino saliendo de Serrano a Nuevo Mundo, 1900.061'S, 64¹9.040'W, 2290 m alt., 3 April 2003, J.R.I. Wood et al. 19576, fl. (LPB); 18 km de Villa Serrano hacia Valle Grande, 1857'S, 6420' W, 2500 m alt., 27 Aug 1994, M. Moraes \& I. Vargas 1834, fl., fr. (LPB, MO, NY); Villa Serrano, comunidad Potreros, área de influencia del Parque Nacional y área de Manejo Integrado Serranía del Iñao, 1904'54"S, 6405'09”W, 1883 m alt., 20 Aug 2005, J. Villalobos et al. 113, fl. (MO); Villa Serrano, comunidad Nuevo Mundo, camino a Phyti, 1900'20"S, 64²0'01'W, 2469 m alt. 18 Aug 2005, J. Villalobos et al. 84, fl. (HSB, MO); camino de Villa Serrano a $2 \mathrm{~km}$ de llegar a las Pampas del Tigre, 1907.01'S, 64²2.22'W, 2258 m alt., 14 Dec 2004, J.R.I. Wood \& H. Huaylla 21198, fl. (LPB); Villa Serrano, comunidad Nuevo Mundo, trayecto del puente Del Diablo a la Pajcha, 1901'14”S, 64¹6'53”W, 2284 m alt., 28 Nov 2005, J. Villalobos et al. 401, fl. (HSB, MO); aprox. 20 minutos de Serrano, trayecto a Pampas del Tigre en el sector el Arrayan, 1905'25’'S, 6415'08’W, 2267 m alt., 15 May 2004, A. Lliully 768, fr. (MO). Juana Azurduy de Padilla, Tarvita, comunidade Cuñuripampa, 1944'54'S, 64²9'29'”, 2092 m alt., 11 Dec 2007, J. Villalobos 1016, fr. (HSB, MO). Santa Cruz: Vallegrande, $5 \mathrm{~km}$ (by air) NW of Los Sitanos, $1 \mathrm{~km} \mathrm{~N}$ of turnoff to Sitanos Altos on road from Abra Tabla to Los Sitanos, 1850'30"S, 6400'W, 2025 m alt., 29 Dec 1989, M. Nee 38351, fr. (NY).

Distribution. Endemic species to central-south of Bolivia, occurring in Chuquisaca and Santa Cruz departments (Fig. 7B).

Ecology. Schinus villosa occurs in steep hillsides between TucumánBolivian forest (Fig. 7B) and in ecotone between montane cloud forest and dry interAndean valleys associated with Podocarpus and Polylepsis forests, between 1883$2650 \mathrm{~m}$. It is known to flower in Feb-April, Aug-Jul and Oct-Dec, and fruit in May, Jul-Aug, Oct and Dec.

Conservation status. We assign a preliminary IUCN threat status as Endangered (EN, A4) based both on extent of occurrence ( $E O O=1,655.802 \mathrm{~km}^{2}$ ) and area of occupancy $\left(\mathrm{AOO}=44.000 \mathrm{~km}^{2}\right)$. The low collection densities of $S$. villosa could be related to fieldwork gap since the access to montane cloud forests in this area can be difficult. Populations are not known within protected areas.

Common name. Chirimolle (Spanish) 

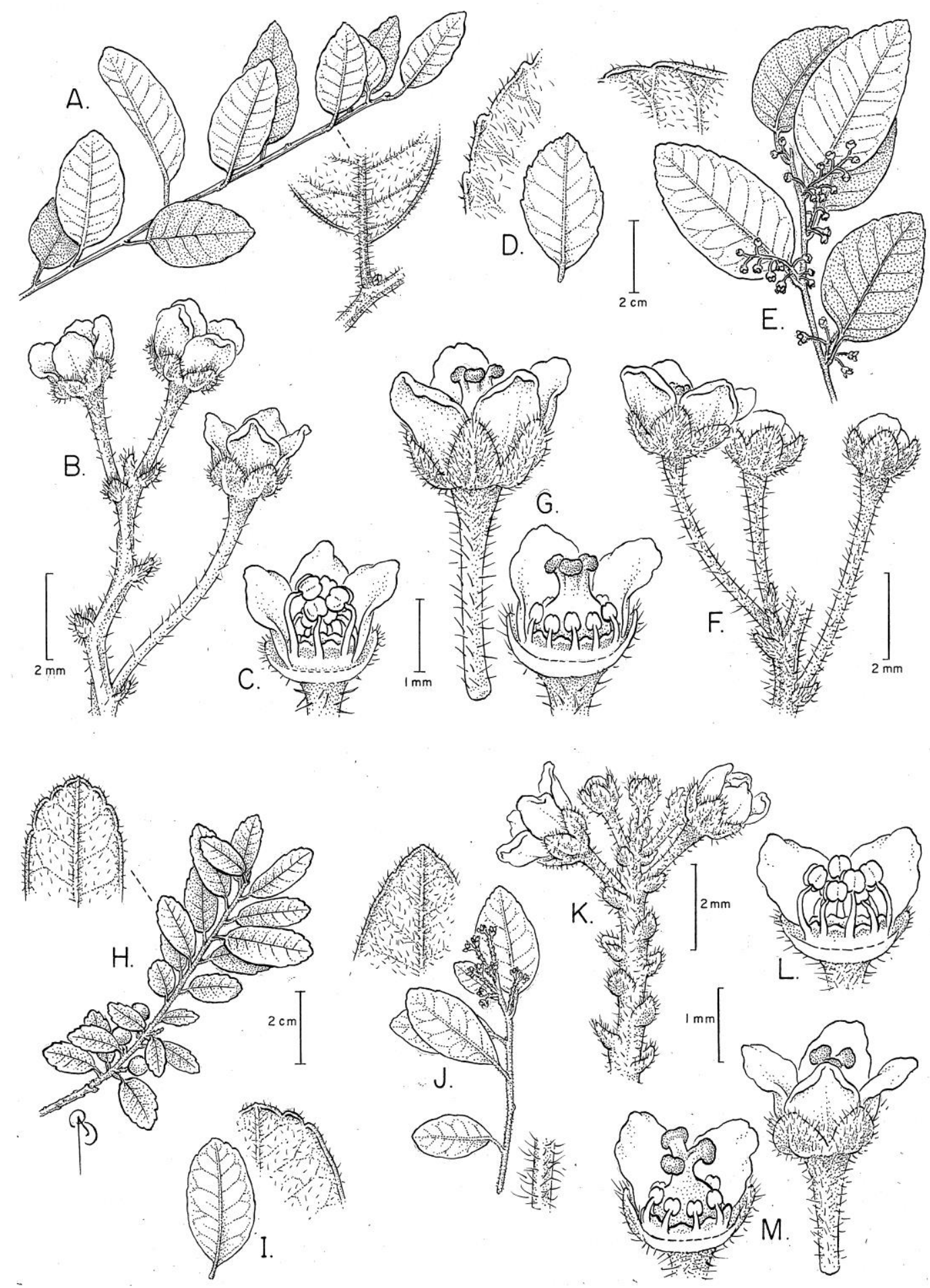

Fig. 9. A-G: Schinus obliqua. A. Sterile branchlet plus detail of the indumentum (inset); B. Inflorescence; C. Staminate flower with one petal and one sepal removed; D. Leaf plus detail of the indumentum, venation and margin (inset); E. Flowering branchlet plus detail of the indumentum, venation and margin on leaf (inset); F. Pistillate inflorescence; G. Pistillate flower plus detail of the flower with two petals and one sepal removed. H-M: Schinus villosa. H. Fruiting branchlet plus detail of the indumentum, venation and margin on leaf (inset); I. Leaf plus detail of the indumentum, venation and margin on distal portion (inset); J. Flowering branchlet plus detail of the indumentum and margin on distal portion of leaf, and the indumentum on branch (inset); K. Inflorescence; L. Staminate flower with two petals and one sepal removed; M. Pistillate flower plus detail of the flower with two petals and one sepal removed. 
Discussion. Schinus villosa may be found sympatrically with $S$. myrtifolia but the former species is easily distinguished by having villous branches (Fig. 9J) with cream-colored trichomes (vs. branches glabrous or sometimes puberulous or with clavate-glandular, transparent trichomes), the adaxial surface of leaves with midvein prominent on proximal portion and flat or impressed distally (vs. with midvein prominulous or flat), and bracts and bracteoles densely villous abaxially (Fig. 9K; vs. pilose or clavate-glandular abaxially). Schinus villosa may also cooccur and resemble $S$. minutiflora because one may encounter individuals (e.g., Villalobos et al. 113, Teran 540) with the branches and leaves sparsely villous and ovate leaves. The former species has petals that are pilose on the midvein and margin, whereas the latter has glabrous petals. Schinus villosa may also co-occur with $S$. pilifera and $S$. areira (neither species treated in this taxonomic revision) in ecotones between montane cloud forests and dry inter-Andean valleys, pre-Puna, Puna or Chaco. Schinus pilifera is distinguished from $S$. villosa by its armed branches, and $S$. areira differs by having compound leaves (vs. unarmed branches and simple leaves in S. villosa).

\section{Doubtful name}

The material collected by $S$. Venturi 9571, housed at NY in which we identified as $S$. gracilipes, was annotated by Venturi as Schinus latifolia (Gillies ex Lindl.) Engl., by Cabrera as S. argentinus, and by Barkley also as S. gracilipes. Both $S$. latifolia (this species not treated in this taxonomic revision) and $S$. gracilipes are legitimate names, whereas $S$. argentinus seems to be a name not validly published since the protologue associated to this name was not find.

\section{References}

Antonelli, A., Nylander, J.A.A., Persson, C. \& Sanmartín, I. 2009. Tracing the impact of the Andean uplift on neotropical plant evolution. Proc. Natl. Acad. Sci. U.S.A. 106, 9749-9754.

Banda-R., K, Delgado-Salinas, A., Dexter, K.G., Linares-Palomino, R., OliveiraFilho, A., Prado, D., Pullan, M., Quintana, C., Riina, R., Rodríguez, M.G.M., Weintritt, J., Acevedo-Rodríguez, P., Adarve, J., Álvarez, E., Aranguren, B.A., Arteaga, J.C., Aymard, G., Castaño, A., Ceballos-Mago, N., Cogollo, Á., Cuadros, H., Delgado, F., Devia, W., Dueñas, H., Fajardo, L., Fernández, Á., Fernández, M.Á., Franklin, J., Freid, E.H., Galetti, L.A., Gonto, R., González-M., R., Graveson, R., Helmer, E.H., Idárraga, Á., López, R., Marcano-Vega, H., 
Martínez, O.G., Maturo, H.M., McDonald, M., McLaren, K., Melo, O., Mijares, F., Mogni, V., Molina, D., Moreno, N.D., Nassar, J.M., Neves, D.M., Oakley, L.J., Oatham, M., Olvera-Luna, A.R., Pezzini, F.F., Dominguez, O.J., Ríos, M.E., Rivera, O., Rodríguez, N., Rojas, A., Särkinen, T., Sánchez, R., Smith, M., Vargas, C., Villanueva, B. \& Pennington, R.T. 2016. Plant diversity patterns in neotropical dry forests and their conservation implications. Science 353 (6306): 1383-1387.

Barkley, F.A. 1944. Schinus L. Brittonia 5(2): 160-198.

Barkley, F.A. 1957. A study of Schinus L. Lilloa 28: 5-110.

Barkley, F.A. 1973. Schinus meyeri, una nueva especie de Anacardiaceas. Lilloa 23(14): 293-296.

Barthlott, W., Mutke, J., Rafiqpoor, M.D., Kier, G. \& Kreft, H. 2005. Global centres of vascular plant diversity. Nova Acta Leopold. 92: 61-83.

Barrett, S.C.H. \& Hough, J. 2013. Sexual dimorphism in flowering plants. Journal of Experimental Botany 64(1): 67-82.

Blandin, P. \& Gareca, Y. 2011. A new subspecies of Morpho (Grasseia) godartii Guérin Méneville, [1844], discovered in sub-humid forests from southern Bolivian Andes (Lepidoptera, Nymphalidae). Bulletin de la Société entomologique de France 116 (3): 291-300.

Bell, C.D. \& Donoghue, M.J. 2005. Phylogeny and biogeography of Valerianaceae (Dipsacales) eith special reference to the South America valerians. Organisms, Diversity and Evolution 5: 147-159.

Brown, A.D., Grau, H.R., Malizia, L.R. \& Grau, A. 2001. Argentina. In M. Kappelle \& A.D. Brown (eds.). Bosques nublados del neotrópico. Instituto Nacional de Biodiversidad INBio, Costa Rica, 623-659 pp.

Brown, A.D., Pacheco, S., Lomáscolo, T., Malizia, L.R. 2005. Ecoregión Yungas: situación ambiental en los bosques andinos yungueños. In A.D. Brown, O.U. Martinez, M. Acerbi \& J. Corcuera (eds.). Situación ambiental Argentina. Fundación Vida Silvestre Argentina, Argentina, pp. 53-72.

Cabrera, A. L. 1976. Regiones fitogeográficas Argentinas. Enciclopedia Argentina de Agricultura y Jardinería, Second Edition, Vol. II, Buenos Aires, Argentina.

Cabrera, A. \& Willink, A. 1973. Biogeografía de América Latina. Washington, DC: Organization of American States, Regional Program of Scientific and Technological Development. 120 pp.

Chen, Z. \& Li, J. 2004. Phylogenetics and Biogeography of Alnus (Betulaceae) Inferred from Sequences of Nuclear Ribosomal DNA ITS Region. International Journal of Plant Sciences 165(2): 325-335. 
Cracraft, J. 1985. Historical biogeography and patterns of differentiation within the South American avifauna: areas of endemism. In P. A. Buckley, M. S. Foster, E. S. Morton, R. S. Ridgely \& F. G. Buckley (Eds.). Neotropical Ornithology. American Ornithologists' Union, Washington, D.C., pp. 49-84.

Cribb, P., Pridgeon, A. \& Roberts, D. 2002. Orchid Research Newsletter 39.

Emmons, L. H. 1997. Mammals of the Río Urucuti Basin, south central Chuquisaca, Bolivia. In T.S. Schulenberg \& K. Awbrey (Eds.). A Rapid Assessment of the Humid Forests of South Central Chuquisaca, Bolivia. RAP Working Papers 8. Conservation International, Washington, D.C., pp. 30-33.

Ferro, L.I., Martínez, J.J. \& Barquez, R.M. 2010. A new species of Phyllotis (Rodentia, Cricetidae, Sigmodontinae) from Tucumán province, Argentina. Mamm. biol. 75: 523-537.

Ficoseco, M.E.A., Vattuone, M.A., Audenaert, K., Catalán, C.A.N. \& Sampietro, D.A. 2014. Antifungal and antimycotoxigenic metabolites in Anacardiaceae species from northwest Argentina: isolation, identification and potential for control of Fusarium species. Journal of Applied Microbiology 116(5): 1262-73.

Fjeldså, J. \& Mayer, S. 1996. Recent Ornithological Surveys in the Valles Region, Southern Bolivia - and the Possible Role of Valles for the Evolution of the Andean Avifauna. Centre for Research on Cultural and Biological Diversity of Andean Rainforests, Kalø, Denmark, 62 pp.

Gareca, Y. \& Blandin, Y. 2011. Morpho (Morpho) helenor (Cramer) (Lepidoptera, Nymphalidae, Morphinae) in Bolivia: Geographical distribution and ecological plasticity, with a description of a new subspecies. Zootaxa 3130: 30-56.

Geml, O., Pastor, N., Fernandez, L., Pacheco, S., Semenova, T.A., Becerra, A.G., Wicaksono, C.Y. \& Nouhra, E.R. 2014. Large-scale fungal diversity assessment in the Andean Yungas forests reveals strong community turnover among forest types along an altitudinal gradient. Molecular Ecology 23: 2452-2472.

Gentry, A.H. 1992. Diversity and floristic composition of Andean forests of Peru and adjacent countries: implications for their conservation. Mem. Mus. Hist. Nat. "Javier Prado" 21: 11-29.

Givinish, T.J., Barfuss, M.H.J., Ee, B.V., Riina, R., Schulte, K., Horres, R., Gonsiska, P.A., Jabaily, R., Crayn, D.M., Smith, A.C., Winter, K., Brown, G.K., Evans, T.M., Holst, B., Luther, H., Till, W., Zizka, G., Berry, P.E., Systma, K.J. 2011. Phylogeny, adaptative, and historical biogeography in Bromeliaceae: Insights from an eight-locus plastid phylogeny. American Journal of Botany 98(5): 872895. 
Givinish, T.J., Barfuss, M.H.J., Ee, B.V., Riina, R., Schulte, K., Horres, R., Gonsiska, P.A., Jabaily, R., Crayn, D.M., Smith, A.C., Winter, K., Brown, G.K., Evans, T.M., Holst, B., Luther, H., Till, W., Zizka, G., Berry, P.E., Systma, K.J. 2014. Adaptive radiation, correlated and contingent evolution, and net species diversification in Bromeliaceae. Molecular Phylogenetics and Evolution 71:55-78.

Hughes, C. \& Eastwood, R. 2006. Island radiation on a continental scale: Exceptional rates of plant diversification after uplift of the Andes. Proc Natl Acad Sci USA 103: 10334 - 10339.

Ibisch, P.L. 1998. Bolivia is a megadiversity country and a developing country. Pp. 213-241 in: Barthlott, W. \& Winiger, M. (eds) Biodiversity - a Challenge for Development Research and Policy. Springer-Verlag, Berlin.

Ibisch, P.L., Beck, S.G., Gerkmann, B., Carretero, A., 2003. Ecoregiones y ecosistemas. In Ibisch, P.L., Mérida, G. (Eds.), Biodiversidad: La riqueza de Bolivia. Estado de conocimiento y conservación. Ministerio de Desarrollo Sostenible. Editorial FAN, Santa Cruz de la Sierra, Bolivia, pp. 47-88.

Johnston, I.M. 1938. Journal Arnold Arboretum 19(3): 191-290

Macbride, J. F. 1951. Anacardiaceae, Flora of Peru. Publ. Field Mus. Nat. Hist., Bot. Ser. 13(3A/1): 238-258.

Mitchell, J.D. 2014. Anacardiaceae. In P.M., Jørgensen, M.H., Nee, M.H. \& S.G.

Beck (eds.). Catálogo de las plantas vasculares de Bolivia. Saint Louis, Missouri: Missouri Botanical Garden, pp. 217-220.

Josse, C., Cuesta, F., Navarro, G., Barrena, V., Cabrera, E., Chacón-Moreno, E., Ferreira, W., Peralvo, M., Saito, J. \& Tovar, A. 2009. Ecosistemas de los Andes del norte y centro. Bolivia, Colombia, Ecuador, Perú y Venezuela. Lima: Secretaría General de la Comunidad Andina, Programa Regional ECOBONAIntercooperation, CONDESAN Proyecto Páramo Andino, Programa BioAndes, EcoCiencia, NatureServe, IAvH, LTAUNALM, ICAE-ULA, CDC-UNALM, and RUMBOL SRL.

Josse, C., Cuesta, F., Navarro, G., Barrena, V., Becerra, M.T., Cabrera, E., ChacónMoreno, E., Ferreira, W., Peralvo, M., Saito, J., Tovar, A. \& Naranjo, L.G. 2009. Physical Geography and Ecosystems in the Tropical Andes. In In S.K. Herzog, R. Martinez, P.M. Jørgensen \& H. Tiessen (eds.) Climate change and biodiversity in the Tropical Andes. Inter-American Institute for Global Change Research (IAI) and Scientific Committee on Problems of the Environment (SCOPE), 348 pp.

Juárez, F.C. \& Novara, L.J. 2007. Anacardiaceae Lindl., Flora del Valle de Lerma. Aportes Botánicos de Salta - Ser. Flora 8(6): 1-28. 
Kessler, M. 1999. Plant species richness and endemism during natural landslide succession in a perhumid montane forest in the Bolivian Andes. Ecotropica 5: 123-136.

Kessler, M. 2000. Elevational gradients in species richness and endemism of selected plant groups in the central Bolivian Andes. Plant Ecology 149: 181-193.

Kessler, M. 2001a. Pteridophyte species richness in Andean forests in Bolivia. Biodiversity and Conservation 10: 1473-1495.

Kessler, M. 2001b. Patterns of diversity and range size of selected plant groups along an elevational transect in the Bolivian Andes. Biodiversity and Conservation, 10: 1897-1921.

Kessler, M. 2002. The elevational gradient of Andean plant endemism: varying influences of taxon-specific traits and topography at different taxonomic levels. Journal of Biogeography 29: 1159-1165.

Kessler, M., Herzog, S.K., Fjeldsa, J. Bach, K. 2001. Species richness and endemism of plant and bird communities along two gradients of elevation, humidity and land use in the Bolivian Andes. Diversity and Distributions 7: 61-77.

Kier, G., kreft, H., Lee, T.M., Jetz, W., Ibisch, P.L., Nowicki, C., Mutke, J. \& Barthlott, W. 2009. A global assessment of endemism and species richness across island and mainland regions. PNAS 106: 9322-9327.

Kromer, T., Kessler, M., Gradstein, S.R. \& Acebey, A. 2005. Diversity patterns of vascular epiphytes along an elevational gradient in the Andes. Journal of Biogeography 32: 1799-1809.

Lagomarsino, L.P, Antonelli, A., Muchhala, N., Timmermann, A., Mathews, S. \& Davis, C.C. 2014. Phylogeny, classification, and fruit evolution of the species-rich Neotropical bellflowers (Campanulaceae: Lobelioideae). American Journal of Botany 101: 2097-2112.

Lloyd, D.G. \& Webb, C.J. 1977. Secondary sex characters in plants. Botanical Review 43(2): 177-216.

López, R.P. 2003. Diversidad florística y endemismo de los valles secos bolivianos. Ecología en Bolivia 38(1): 27-60.

Luebert, F. \& Weigend, M. 2014. Phylogenetic insights in Andean plant diversification. Frontiers in Ecology and Evolution 2: 27.

Mallet, J. 1995. A species definition for the modern synthesis. Trends in Ecology and Evolution 10: 294-299.

Martín, C.M., Panassiti, B. \& Entrocassi, G. 2016. Vascular flora of a Yungas forest in Jujuy province, northwestern Argentina. Check List 12(6): 1-10. 
Morales, J.M., Siromba, M. \& Brown, A.D. 1995. Riqueza de árboles en las Yungas argentinas. In A.D. Brown \& H.R. Grau (eds.) Investigación, conservación y desarrolo en Selvas Subtropicales de Montaña. Proyecto de desarrolo agroflorestal/ L.I.E.Y. 163-174 pp.

Morrone, J.J. 2006. Biogeographic areas and transition zones of Latin America and the Caribbean Islands based on panbiogeographic and cladistic analyses of the entomofauna. Annu. Rev. Entomol. 51: 467-494.

Muñoz, J.D. 2000. 153. Anacardiaceae. In A.T. Hunkizer (ed.) Flora Fanerogamica Argentina. Proflora (Conicet), Cordoba, fasc. 65, p.1-28.

Murray, A.P., Rodriguez, S., \& Alza, N.P. 2012. Chemical constituents and biological activities of plants from the genus Schinus. Recent Progress in Medicinal Plants 32: 261-287.

Mutke, J., Jacobs, R., Meyers, K., Henning, T. \& Weigend, M. 2014. Diversity patterns of selected Andean plant groups correspond to topography and habitat dynamics, not orogeny. Front Genet. 5.

Myers, N., Mittermeier, R.A., Mittermeier, C.G., da Fonseca, G.A.B. \& Kent, J. 2000. Biodiversity hotspots for conservation priorities. Nature 403: 853-858.

Ojeda, R.A., Barquez, R.M., Stadler, J. \& Brandl, R. 2008. Decline of mammal species diversity along the Yungas Forest of Argentina. Biotropica 40(4): 515521.

Pennington, R.T. \& Dick, C.W. 2010. Diversification of the Amazonian flora and its relation to key geological and environmental events: a molecular perspective. In C. Hoorn \& F.P. Wesselingh, F.P. (eds). Amazonia: Landscape and Species Evolution: A Look into the Past. Blackwell, pp. 373-385.

Richter, M., Diertl, K.-H., Emck,P., Peters,T. \& Beck, E. 2009. Reasons for an outstanding plant diversity in the tropical Andes of Southern Ecuador. Landsc. Online 12, 1-35.

Sampietro, D.A., Belizan, M.M.E., Baptista, Z.P.T., Vattuone, M.A. \& Catalán, C.A.N. 2014. Essential Oils from Schinus Species of Northwest Argentina: Composition and Antifungal Activity. Natural Product Communications 9(7): 1019-1022.

Sanmartín, I. 2014. Biogeography. In P. Vargas \& R. Zardoya (eds.). Tree of Life. Sunderland, MA: Sinauer Associates, Inc, 555-576 pp.

Särkinen, T.E., Knapp S. \& Nee, M. 2015. Two new non-spiny Solanum species from the Bolivian Andes (MorelloidClade). PhytoKeys 47: 97-109.

Särkinen, T.E., Marcelo-Peña, J.L., Yomona, A.D., Simon, M.F., Pennington, R.T. \& Hughes, C.E. 2011. Underestimated endemic species diversity in the dryinter- 
Andean valley of the Río Marañón, northern Peru: an example from Mimosa (Leguminosae, Mimosoideae). Taxon 60: 139-150.

Schulenberg, T.S., Holst., B.K., Foster, R.B. \& Emmons, L.H. 1997. Introduction. In T.S. Schulenberg \& K. Awbrey (Eds.). A Rapid Assessment of the Humid Forests of South Central Chuquisaca, Bolivia. RAP Working Papers 8. Conservation International, Washington, D.C., pp. 6-11.

Sklenàr, P. \& Jørgensen, P.M. 1999. Distribution patterns of páramo plants in Ecuador. Journal of Biogeography 26: 681-691.

Stafleu, F.A. \& Cowan, R.S. 1976. Taxonomic Literature. 2 ed. Vols. 1-7. Utrecht: Bohn, Scheltema \& Holkema.

Steudel, B. 2011. A new species of Stelis (Pleurothallidinae, Orchidaceae) from South Yungas, Bolivia. Phytotaxa 38: 49-52.

Swenson, J.J., Young, B.E., Beck, S., Comer, P., Córdova, J.H., Dyson, J., Embert, D., Encarnación. F., Ferreira, W., Franke, I., Grossman, D., Hernandez, P., Herzog, S.K., Josse, C., Navarro, G., Pacheco, V., Stein, B.A., Timaná, M., Tovar, A., Tovar, C., Vargars, J. \& Zambrana-Torrelio, C.M. 2012. Plant and animal endemism in the eastern Andean slope: challenges to conservation. BMC Ecology 12:1.

Tank, D.C. \& Olmstead, R.G. 2009. The evolutionary origin of a second radiation of annual Castilleja (Orobanchaceae) species in South America: the role of long distance dispersal and allopolyploidy. American Journal of Botany 96(10): 19071921.

Varela, F.J. \& Novara, L.J. 2007. Anacardiaceae Lindl. Flora del Valle de Lerma. Aportes Botánicos Salta, Ser. Flora 8(6): 1-28.

Vásquez, R. \& Ibisch, P.L. 2000. Orquídeas de Bolivia / Orchids of Bolivia. Diversidad y Estado de Conservación / Diversity and Conservation Status. Vol. 1. Pleurothallidinae. Editorial FAN, Santa Cruz de la Sierra, Bolivia.

Vásquez, R., Ibisch, P.L. \& Gerkmann, B. 2003. Diversity of Bolivian Orchidaceae a challenge for taxonomic, floristic and conservation research. Org. Divers. Evol. 3: 93-102.

Olson, D.M., Dinerstein, E., Wikramanayake, E.D., Burgess, N.D., Powell, G.V.N., Underwood, E.C., D’Amico, J.A., Itoua, I., Strand, H.E., Morrison, J.C., Loucks, C.J., Allnutt, T.F., Ricketts, T.H., Kura, Y., Lamoreux, J.F., Wettengel, W.W., Hedao, P. \& Kassem, K.R. 2001. Terrestrial ecoregions of the world: a new map of life on Earth. BioScience 51: 933-938. 


\section{Index to scientific names in Schinus sect. Myrtifolia}

Accepted names are in boldface; synonyms taxa are in italics. Each name is followed by its number (for synonyms, the number of its accepted name) in this paper.

Schinus congestiflora Silva-Luz \& Pirani, 1

Schinus gracilipes I.M. Johnst., 2

Schinus gracilipes var. pilosa Barkley, 2

Schinus meyeri F.A. Barkley, 3

Schinus microphylla I.M. Johnst., 4

Schinus dependens Ortega var. parviflora Marchand, 4

Duvaua dependens (Ortega) DC. var. parviflora (Marchand) Arechaval., 4

Schinus polygama (Cav.) Cabrera fo. parviflora (Marchand) Cabrera, 4

Schinus polygama (Cav.) Cabrera var. parviflora (Marchand) F.A. Barkley, 4

Schinus dependens Ortega var. crenata Engl., 4

Duvaua dependens (Ortega) DC. var. crenata (Engl.) Arechaval., 4

Schinus dependens Ortega var. andina Engler, 4

Schinus andina (Engl.) I.M. Johnst., 4

Schinus minutiflora (Loes.) Silva-Luz, 5

Schinus dependens var. andina Engl. fo. grandifolia Loes., 5

Schinus myrtifolia (Griseb.) Cabrera, 6

Cybianthus myrtifolius Griseb., 6

Schinus obliqua Silva-Luz \& J.D. Mitch., 7

Schinus subtridentata (Kuntze) Silva-Luz, 8

Schinus huyngan var. subtridentata Kuntze, 8

Schinus andina var. subtridentata (Kuntze) F.A. Barkley, 8

Schinus tarijensis Silva-Luz \& J.D. Mitch., 9

Schinus venturii F.A. Barkley, 10

Schinus villosa Silva-Luz \& J.D. Mitch., 11

\section{Numerical list of taxa}

1. Schinus congestiflora Silva-Luz \& Pirani

2. Schinus gracilipes I.M. Johnst.

3. Schinus meyeri F.A. Barkley

4. Schinus microphylla I.M. Johnst. 
5. Schinus minutiflora (Loes.) Silva-Luz

6. Schinus myrtifolia (Griseb.) Cabrera

7. Schinus obliqua Silva-Luz \& J.D. Mitch.

8. Schinus subtridentata (Kuntze) Silva-Luz

9. Schinus tarijensis Silva-Luz \& J.D. Mitch.

10. Schinus venturii F.A. Barkley

11. Schinus villosa Silva-Luz \& J.D. Mitch.

\section{List of exsiccatae}

The numbers in parentheses correspond to the species-numbers in the preceding numerical list of taxa.

Abbott, J. 7233 (1)

Acevedo-Rodriguez, P. 6574 (1)

Altamirano, J.P. 474 (1)

Apaza, O 32 (5)

Arbo, M.M. 9084 (3)

Arroyo, L. 1839 (1), 1883 (5), 3875 (5), 3969 (1)

Beck, S.G. 795 (10), 1370 (4), 2335 (4), 2363 (4), 3922 (4), 4228 (4), 4376 (8), 6296

(5), 8462 (4), 8652 (4), 9616 (3), 9656 (3), 11368 (4), 11658 (4), 14337 (4), 17233

(4), 26780 (6), 29317 (4), 31464 (7), 31470 (10)

Biloni, J.S. 6023 (6)

Brandbyge, J. 712 (8), 730 (1)

Bricker, J.S. $182(2)$

Burkart, A. 30523 (6)

Cardenas, M. 7605 (1)

Carretero, A. 1197 (5)

Casas, J.F. $7790(8)$

Cervantes, E. 13 (8)

Charpin, A. 23077 (2)

Cialdella, A.M. 67 (2)

Davidson, C. 3767 (1)

Dematteis, M. 751 (2)

Farfán, J. 367 (4)

Fernández, E. 2498 (1), 3553 (5)

Feuerer, T. 4019 (8)

Fiebrig, K. 2291 (10), 2477 (9)

Fuentes, A. 6711 (4)

Gallegos, S. 346 (9), 354 (9), 367 (9)

García, E. 403 (4)

Gutierrez, E. 696 (8)

Gutiérrez, J. 500 (6)

Gutte, P. 104 (4)

Hensen. I. 1906 (8)

Herzog, T.C.J. 1714 (5)

Hunziker, A.T. 19161 (2), 20419 (2)

Jardim, A. 2108 (1)

Jimenez, M. 678 (5)

Kessler, M 3133 (7), 3163 (7), 3243 (5), 2977 (8) 
Krapovickas, A. 17489 (6)

Kuntze, O. s.n. (8)

Lectae, A.M.B. 160 (8), 895 (4)

Legname, P.R. 4194 (2), 7274C (6), 7944 (10), 9757C (3)

Lewis, M 35118 (8), 35361 (8), 40623 (8)

Liberman, M 1563 (9), 2300 (8)

Lillo, M. 1163 (2), 2060 (2)

Linneo, I. 774 (8), 1536 (1)

Lliully, A. 768 (11)

Lorentz, P.G. 317 (6)

Mandon, G. 768 (4)

Mendoza, M. 444 (1)

Mercado, M. 2048 (1), 2087 (1)

Moraes, M 1834(11)

Moraes, M 690 (4), 1809 (5)

Moretti 2038 (2)

Morrone, O. 3247 (6), 3824 (3)

Nee, M 30518 (4), 38351 (11), 38397 (5), 38420 (5), 38440 (5), 40331 (1), 40702 (1), 40732 (1), 45301 (1), 48946 (1), 49631 (1), 50015 (1), 50716 (1), 52429 (1), $52432(1), 52504(1)$

Novara, L.J. 9100 (3), 9393 (2)

Nuñez, P. 7007 (4), 7011 (4)

Olea, D. 30 (2), $110(2)$

Pentland, J.B. $18(4)$

Renvoize, S.A. 3458 (6)

Rodriguez, D. 29 (2)

Saldías, M. 546 (5)

Schiavone, M.M. 11707C (3), 11883C (3)

Schinini, A. 34717 (10)

Schreiter, R. 3312 (2), 6461 (2), 6547 (2)

Serrano, M 656 (11), 4865 (10), 5050 (9), 5055 (9), 5347 (10), 6805 (5), 6985 (5)

Silva-Luz, C.L. 234 (1), 241 (6), 242 (6), 243 (6), 250(1), 251 (1), 252 (1), 255 (4), 288 (6), 292 (6), 293 (6), 322 (6), 324 (6), 325 (6), 326 (6), 327 (6), 334 (4)

Sleumer, H. 2787 (6)

Solomon, J.C. 6747 (4), 10327 (7), 10458 (10), 10481(10), 10610 (6), 10927 (10), $14349(4), 14444$ (8), $15916(1), 16035$ (5)

Soto, D. 156 (1)

Spegazzini, C.L. 1362 (2)

Steinbach, J. 8346 (5)

Steiphen 32 (4)

Teran, J. 540 (11), 1125 (8), 1303 (1)

Torrico, G. 120 (8), 533 (8)

Vaca, A.A. 267 (2)

Vargas, I.G. 310 (1), 817 (1), 1305 (1), 1508 (1), 2389 (1), 7046 (1)

Vargas, L. 205 (4)

Velayos, M. 11118 (8)

Venturi, S. 3887 (2), 4173 (2), 9571 (2), 10260 (2)

Vervoorst, F 4492 (10), 4494 (3), 7625C (6)

Villalobos, J. 84 (11), 113 (11), 401 (11), 1016 (11)

Weberbauer, A. 5552 (4), 5839 (4)

West, J. 3747 (4)

Wood, J.R.I 7794 (8), 11623 (7), 12708 (11), 18937 (4), 19554 (5), 19576 (11), 21198 (11) 21299 (1)

Zapata, S.R. $43(6)$

Zenteno, F. 3593 (3), 3657 (9), 3690 (6), 4517 (10) 
A sistemática filogenética tem proporcionado uma base robusta para hipóteses de reconstrução de eventos que guiaram a distribuição e diversidade biológica atual. Novas abordagens têm integrado perspectivas filogenéticas, filogeográficas, ecológicas, paleontológicas, tectônicas e climáticas a fim de testar cenários de diversificação de espécies em relação à história da paisagem (Badgley et al. 2017). Dentro desse contexto, Weeks et al. (2014) testaram recentemente padrões biogeográficos e hipóteses de conservantismo e evolução de nicho filogenético em "Terebinthaceae", uma designação antiga de família que compreendia táxons hoje tratados como membros de Anacardiaceae e Burseraceae. No entanto, ainda são escassas as investigações macroevolutivas em Anacardiaceae e mesmo os estudos visando o entendimento das relações entre os seus táxons. Até o momento, existem estudos filogenéticos dos gêneros Pistacia, Protorhus, Rhus e Toxicodendron e um trabalho em andamento com Mangifera'.

Schinus é o gênero de Anacardiaceae com maior riqueza específica na América do Sul, constituído por cerca de 42 espécies distribuídas em ampla diversidade de habitats. Desde 1753, quando as primeiras espécies de Schinus foram descritas por Linnaeus, botânicos como Ortega (1798), Kunth (1824) Lindley (1833), Philippi (1863), Marchand (1869), Engler (1876), Johnston (1938), Cabrera (1938), Barkley (1944, 1957), Fleig (1987, 1989) e Muñoz $(1999,2000)$ se empenharam em demonstrar a diversidade no gênero por meio de tratamentos taxonômicos ou descrição de táxons. O histórico taxonômico de Schinus é marcado pelo reconhecimento de categorias infragenéricas, como subgêneros ou seções, as quais apresentam circunscrições similares. Além disso, muitos táxons infraespecíficos, principalmente variedades e formas têm sido reconhecidos. A delimitação entre as espécies de Schinus, principalmente entre os táxons de folhas simples, é complexa devido à ampla variação morfológica das estruturas vegetativas, sendo que há evidências recentes de que essa variação também pode estar relacionada ao estádio de desenvolvimento da planta. Contrastando com essa variação vegetativa, as estruturas reprodutivas em Schinus apresentam morfologia bastante uniforme, o que limita a seleção de caracteres morfológicos que poderiam ser usados na delimitação das espécies. Apesar do número considerável de

\footnotetext{
${ }^{1}$ Comunicação pessoal de Emily Warschefsky, aluna de doutorado da Florida International University \& Fairchild Tropical Botanic Garden, em 21 de julho de 2016.
} 
trabalhos taxonômicos disponíveis sobre o gênero, a delimitação das espécies de Schinus ainda é bastante controvertida.

A carência de estudos filogenéticos em táxons de Anacardiaceae, sobretudo na região Neotropical, assim como os problemas taxonômicos de Schinus, motivou o desenvolvimento deste estudo. Nesse contexto, esta tese de doutorado teve como objetivos principais testar a monofilia de Schinus e das categorias infragenéricas e investigar as relações filogenéticas no gênero. Além disso, almejou produzir estudos taxonômicos mais estáveis baseados no estudo filogenético de Schinus.

Nossos resultados, baseados em evidências de onze marcadores moleculares (nucleares e plastidiais), confirmam que Schinus é um gênero monofilético fortemente sustentado, no entanto, as categorias infragenéricas tradicionalmente reconhecidas como $S$. subg. Duvaua sect. Duvaua e $S$. subg. Duvaua sect. Pseudoduvaua são polifiléticas, e baseadas em caracteres homoplásticos. As análises filogenéticas evidenciam oito linhagens bem sustentadas (com exceção de $S$. sect. Atlantica), as quais são aqui utilizadas como base para a proposição da nova classificação seccional. O estudo filogenético evidencia relações entre os táxons de Schinus que não haviam sido demonstradas anteriormente e, por isso, as seções propostas aqui diferem das categorias infragenéricas tradicionalmente reconhecidas. Os atributos morfológicos investigados durante este estudo mostram-se relevantes para caracterizar os principais clados obtidos, alguns deles emergindo como possíveis sinapormofias. Por exemplo, um grande clado composto por cinco seções parece ser bem sustentado pela transição para folhas simples, a partir de ancestrais com folhas pinadas (sendo esta a condição vigente no grado basal de três seções e predominante entre os demais gêneros da família). No entanto, as análises de reconstrução de caracteres ancestrais demonstram um alto grau de homoplasia na maioria do atributos, principalmente naqueles tradicionalmente utilizados na taxonomia infragenérica do gênero, como a presença de ramos terminando em espinhos e os tipos de inflorescência. Nossos dados também sugerem possível correlação do fenótipo espinescente em Schinus com ocorrência em áreas com grande incidência de herbivoria, e isso pode ser melhor investigado por meio de estudo de ecologia evolutiva. Do mesmo modo, as evidências aqui obtidas de que as principais linhagens de Schinus apresentam diferentes tamanhos de pétalas em relação aos estames devem suscitar a realização de estudos de biologia reprodutiva, em particular relacionados a polinização. Cada linhagem é caracterizada por apresentar pétalas maiores que os estames, ou pétala com 
comprimento igual ou pétalas menores que eles. Tais padrões parecem estar relacionados com a área geográfica onde cada linhagem ocorre e, consequentemente, pode envolver polinizadores diferentes. Os clados recuperados nas análises filogenéticas ocorrem em alopatria ou são ecologicamente distintos. Este padrão sugere que o processo de vicariância pode ter sido relevante na história biogeográfica e na diversificação das espécies de Schinus. Dessa maneira, a investigação dos padrões biogeográficos associados à diversificação de táxons de Anacardiaceae parece particularmente promissor e pode contribuir com 0 conhecimento das vegetações da América do Sul Austral.

Este estudo filogenético de Schinus constitui a primeira fase de uma série de estudos sistemáticos planejados, que visam a realizar revisões taxonômicas de todas as seções do gênero. Nesta linha, a tese apresenta o tratamento taxonômico de $S$. sect. Myrtifolia, um clado de espécies de folhas simples que compreende 11 táxons, em sua maioria endêmicos das Yungas e florestas Tucumano-Bolivianas, com outras duas espécies ocorrendo também em áreas de pre-Puna, Puna e nos vales secos interandinos da Argentina, Bolívia e Peru. O estudo morfológico traz dados que contribuem para solucionar os significativos problemas de circunscrição taxonômica existentes atualmente, principalmente entre $S$. andina e $S$. myrtifolia. As análises morfológicas detalhadas de exsicatas permitem a descrição de quatro novas espécies na seção, além de duas combinações novas. Em termos de conservação biológica, os estudos das coleções de herbários e de campo evidenciam que a maioria das espécies da seção tem distribuição geográfica restrita, sendo que seis espécies foram avaliadas como "Em perigo" e duas como "Vulneráveis", seguindo os critérios da IUCN. Dessa forma, nossos dados reforçam a necessidade de ações voltadas para a conservação das florestas TucumanoBolivianas e a Yungas, áreas que apresentam elevado grau de endemismo, como já evidenciado para outros organismos.

Em suma, este estudo filogenético de Schinus, realizado pela primeira vez com uma amostragem abrangente de todas as linhagens componentes do gênero permite considerável aprimoramento da sistemática de Schinus. A perspectiva é que os próximos trabalhos no gênero incluam as revisões taxonômicas das demais seções, a descrição de espécie críptica evidenciada ao longo deste trabalho, o estudo biogeográfico do gênero associado à diversificação das Anacardiaceae da América do Sul Austral e a investigação de caracteres estruturais particulares como possíveis inovações-chave no gênero. 
Badgley, C., Smiley, T.M., Terrry, R., Dawis, E.B., DeSantisL.R.G., Fox, D.L., Hopkins, S.S.B., Jezkova, T., Matocq, M.D., Matzke, N.,McGuire, J.L., Mulch, A., Riddle, B.R., Roth, V.L., Samuels, J.X., Strömberg, C.A.E., Yanites, B.J. 2017. Biodiversity and Topographic Complexity: Modern and Geohistorical Perspectives. Trends in Ecology and Evolution 32(3): 211-226.

Barkley, F.A., 1944. Schinus L. Brittonia 5(2): 160-198.

Barkley, F.A. 1957. A study of Schinus L. Lloydia 28: 5-110.

Cabrera, A.L. 1938. Revision de las Anacardiáceas Austroamericanas. Revista del Museo de La Plata NS 2: Bot. 6: 1-64.

Engler, A. 1876. Anacardiaceae. In Martius, C.F.P. \& Eichler, A.G. (eds.) Flora brasiliensis. Fleischer, Leipzig, vol.12, pars 2, p. 367-418.

Fleig, M. 1987. Anacardiaceae: flora ilustrada do Rio Grande do Sul. Boletim do Instituto de Biociências, Porto Alegre 42: 1-72.

Fleig, M. 1989. Anacardiáceas. In R. Reitz (ed.) Flora llustrada catarinense. Herbário Barbosa Rodrigues, Itajaí, 64 p.

Johnston, I.M. 1938. Journal Arnold Arboretum 19(3): 191-290.

Kunth, K.S. 1824. Annales des Sciences Naturelles (Paris) 2: 340.

Lindley, J. 1833. Edwards's Botanical Register 19.

Linnaeus, C. 1753. Species Plantarum. Salvius, Stockholm.

Marchand, N.L., 1869. Révision du groupe des Anacardiacées. Balliere, Sons, Paris.

Muñoz, J.D. 1990. Anacardiaceae. In Flora del Paraguay. Conservatoire et Jardin botaniques de la Ville de Géneve; Missouri Botanical Garden, Saint Louis, p. 784.

Muñoz, J.D. 2000. 153. Anacardiaceae. In A.T. Hunkizer (ed.) Flora Fanerogamica Argentina. Proflora (Conicet), Cordoba, fasc. 65, p.1-28.

Ortega, C.G. 1798. Novarum, aut rariorum plantarum Horti Reg. Botan. Matrit.: descriptionum decades, cum nonnullarum iconibus 8: 102.

Philippi, R.A. 1863. Jeografía de Chile, Catálogo de las plantas recojidas. Anales de la Universidad de Chile 23: 451, 462. 1863.

Weeks, A., Daly, D.C. \& Simpson, B.B. 2005. Phylogenetic relationships and historical biogeography of the Burseraceae based on nuclear and chloroplast sequence data. Molecular Phylogenetics and Evolution 35: 85-101. 


\section{Resumo}

Pouca atenção tem sido direcionada para Schinus L., gênero americano conhecido sobretudo pelas suas espécies cultivadas e invasoras. Na América do Sul Austral é o gênero da família Anacardiaceae com maior riqueza específica, constituído por cerca de 42 espécies distribuídas em ampla diversidade de habitats, principalmente os áridos ou semi-áridos, estendendo-se também às florestas nebulares dos Andes e do domínio da Mata Atlântica. A mais completa revisão do gênero foi realizada por Fred Alexander Barkley, botânico norte-americano, em 1957, que reconheceu dois subgêneros, S. subg. Schinus e S. subg. Duvaua, sendo o último subdividido em duas seções. Estudos subsequentes indicaram inconsistências morfológicas na circunscrição dessas categorias infragenéricas e a delimitação de várias espécies ainda é complicada. Até o momento, Schinus foi pouco amostrado nos estudos filogenéticos da família, uma vez que não constituía o grupo alvo desses estudos e, por isso, as hipóteses sobre a monofilia do gênero e o entendimento das relações entre suas espécies ainda é muito limitado. Nesse contexto, esta tese teve como objetivos principais testar a monofilia de Schinus e das categorias infragenéricas e investigar as relações filogenéticas no gênero. No primeiro capítulo, apresentamos a filogenia de Schinus baseada em sequências de DNA de 11 marcadores, sendo nove nucleares e dois plastidiais. A amostragem baseou-se na última revisão taxonômica do gênero e incluiu 47 táxons de Schinus, além de 48 espécimes de gêneros de Anacardiaceae proximamente relacionados a esse gênero. Foram realizadas análises filogenéticas individuais e combinadas utilizando inferências Bayesiana, máxima parcimônia e de máxima verossimilhança. Elaboramos uma matriz morfológica, incluindo caracteres vegetativos anatômicos, baseada na análise de materiais herborizados e fixados provenientes de coletas a campo estrategicamente realizadas em pontos selecionados da ampla distribuição do grupo focal, para obtenção de amostras de todos os táxons conhecidos de Schinus. A reconstrução de estados ancestrais de vários caracteres morfológicos foi realizada pelo critério de parcimômia, utilizando como base a árvore filogenética proveniente da análise combinada Bayesiana. Essa reconstrução morfológica teve como principais objetivos: 1 . buscar um entendimento mais amplo sobre as relações interespecíficas em Schinus e entre gêneros proximamente relacionados, 2 identificar caracteres morfológicos e possíveis sinapormofias dos principais clados, e 3. discutir as hipóteses sobre a evolução de caracteres estruturais em Schinus. As análises filogenéticas demonstraram que Schinus é um gênero monofilético fortemente sustentado, no entanto, as categorias infragenéricas $S$. 
subg. Duvaua sect. Duvaua and S. subg. Duvaua sect. Pseudoduvaua emergiram polifiléticas, sendo homoplásticos os caracteres tradicionalmente utilizados na sua circunscrição. Os resultados evidenciaram oito principais linhagens fortemente sustentadas em Schinus, sendo que as espécies de folhas compostas (pinadas) constituem as três primeiras linhagens a divergirem, formando um grado, e as espécies de folhas simples emergem agrupadas em um grande clado bem sustentado, o qual apresenta cinco linhagens principais, também com boa sustentação. No entanto, as relações interespecíficas dentro de alguns clados permanece pouco resolvida. As reconstruções de estados ancestrais demonstram que alguns atributos morfológicos e anatômicos foliares são relevantes na caracterização e possivelmente sinapomorfias de algumas linhagens. No entanto, a maioria dos caracteres, principalmente os tradicionalmente empregados nas circunscrição de grupos em Schinus, demonstram um nível alto de homoplasia. De acordo com as novas evidências provenientes desse estudo, apresentamos no primeiro capítulo uma nova classificação seccional em Schinus, assim como chave de identificação para as oito seções, lista de espécies compondo cada seção, além de comentários taxonômicos, de distribuição geográfica e sobre ecologia. As seções propostas nesse estudo podem ser caracterizadas pela combinação de um conjunto de caracteres morfológicos associados à distribuição geográfica, uma vez que elas correspondem a linhagens alopátricas ou ecologicamente distintas. $O$ estudo filogenético constitui a primeira fase de uma série de estudos sistemáticos que estão planejados e visam realizar o tratamento taxonômico de todas as seções de Schinus. Por isso, no segundo capítulo desta tese apresentamos a revisão taxonômica de $S$. sect. Myrtifolia, um clado notável de espécies de folhas simples que podem alcançar as mais elevadas altitudes dentre as espécies de Anacardiaceae (até $3900 \mathrm{~m}$ de altitude). Os 11 táxons que compõem essa seção são em sua maioria endêmicos das Yungas e florestas Tucumano-Bolivianas, e outras duas espécies também ocorrem em áreas de pre-Puna, Puna e nos vales secos interandinos da Argentina, Bolivia e Peru. Apesar das reconstruções morfológicas demonstrarem que a maioria dos caracteres morfológicos apresentam um elevado grau de homoplasia, o que torna difícil a diagnose dos principais clados, S. sect. Myrtifolia é a única seção que apresenta flores tetrâmeras e frutos lateralmente achatados, atributos incomuns e, portanto, aqui apontados como possíveis sinapormofias deste clado. Suas espécies foram reconhecidas anteriormente em S. subg. Duvaua sect. Pseudoduvaua, exceto por S. microphylla, a qual foi reconhecida como membro de $S$. subg. Duvaua sect. Duvaua. Problemas de delimitação específica existentes em S. sect. Myrtifolia têm sido negligenciados, 
uma vez que a maioria dos estudos taxonômicos no gênero frequentemente têm se limitado a destacar as dificuldades taxonômicas em $S$. subg. Duvaua sect. Duvaua. O presente estudo morfológico evidencia um número significante de problemas de circunscrição taxonômica, principalmente entre $S$. andina e $S$. myrtifolia. As análises morfológicas detalhadas de um considerável número de exsicatas mostraram quatro novas espécies, as quais são descritas neste trabalho. Apresentamos chave de identificação para as espécies, descrições morfológicas, sinonímia, tipos nomenclaturais, incluindo três lectotipificações, duas combinações novas, ilustrações, mapas de distribuição e avaliação do estado de conservação de todas as espécies. As novidades taxonômicas apresentadas aqui, referentes às espécies de $S$. sect. Myritfolia, representam uma tentativa de demonstrar a complexidade morfológica e evidenciar problemas de identificação de espécies levando em consideração uma amostragem grande e revisão nomenclatural cuidadosa. Dessa forma, esperamos destacar a gama de variação morfológica, principalmente entre $S$. andina e $S$. myrtifolia, táxons pouco estudados até 0 momento. Em suma, o estudo filogenético de Schinus, realizado pela primeira vez com uma amostragem abrangente de todas as linhagens componentes do gênero, oferece oportunidades para novos estudos taxonômicos, evolutivos e biogeográficos no gênero. Em particular, análises biogeográficas associadas à diversificação desse gênero e táxons relacionados de Anacardiaceae parecem muito promissoras para ampliar o conhecimento sobre a história das formações vegetacionais da América do Sul Austral. 
Schinus, a genus best known by its few cultivated and invasive species, is the largest genus of Anacardiaceae in southern South America. It is remarkably diverse compared to closely related genera, with approximately 42 species, most of which occur in several arid vegetation types and extending into Andean and Atlantic moist forests. The most comprehensive taxonomic revision of the genus dates to 1957, which recognized S. subg. Schinus and S. subg. Duvaua, the latter of which was further divided into two sections. Subsequent studies have highlighted morphological inconsistencies in this infrageneric classification, and species delimitation remains a challenge. Schinus has been poorly sampled in previous phylogenetic studies of Anacardiaceae, and thus any assumptions about its monophyly and relationships (particularly among its species and infrageneric categories) remain untested. This thesis aimed to test the monophyly of Schinus and its infrageneric circumscriptions, and also investigate the phylogenetic relationships. In the first chapter, we present the phylogenetic relationships of all Schinus species using nine nuclear and two plastid DNA sequence regions, most of them developed recently for Commiphora (Burseraceae). The maximum parsimony, maximum likelihood, and Bayesian inference included 47 taxa based on the latest taxonomic revision of the genus, and 48 specimens of Anacardiaceae genera closely related to Schinus. We also constructed a morphological dataset, including vegetative anatomical features, based on analysis of herbarium specimens and fresh material obtained through fieldwork, and compared these characters to hypotheses based on molecular evidence in order to: 1. achieve a better understanding of the relationships among its species and to related genera, 2 . identify morphological characters and putative synapomorphies for major clades, and 3. discuss hypotheses regarding the evolution of structural traits in the group. Our analyses strongly support the monophyly of Schinus, but also indicate that its infrageneric groups $S$. subg. Duvaua sect. Duvaua and $S$. subg. Duvaua sect. Pseudoduvaua are polyphyletic and have been defined using homoplastic characters. The phylogenetic relationships that emerged from our analyses include eight strongly supported lineages (except for $S$. sect. Atlantica), in which compoundleaved taxa were the earliest diverging lineages, forming a grade of three strongly supported clades, and the largest Schinus clade consists of simple-leaved species, and has five well-supported main lineages. However the relationships among closely related species remain unclear in some clades. Ancestral state reconstructions demonstrate that some morphological and leaf-anatomical 
characters are valuable in characterizing some lineages, and may serve as potential synapomorphies to define these clades. By contrast, most of the traits that have traditionally been used to circumscribe groups in Schinus show high levels of homoplasy. In light of these results, we present in the first chapter a novel sectional classification of Schinus, an identification key for the sections and comments on the taxonomy, geographic distribution and ecology. The eight monophyletic sections proposed here are recognized by a combination of character states associated with geographic distribution, corresponding to lineages that are mostly allopatric or at least ecologically distinct. This study is the first phase of a long-term effort to produce systematics studies and taxonomic review for all species of Schinus. In this way, we present in the second chapter the taxonomic revision of $S$. sect. Myrtifolia, a remarkable simple-leaved clade in which species reach the highest elevations within Anacardiaceae (up to 3,900 m altitude). The 11 species of this section are mostly endemic of Yungas and Tucumán-Bolivian forests, and two species also occur in pre-Puna, Puna and dry inter-Andean valleys from Argentina, Bolivia and Peru. The fact that most of the morphological traits present high levels of homoplasy, the diagnosis of the main clades within Schinus is a challenge, except for $S$. sect. Myrtifolia whose species have tetramerous flowers and fruits laterally compressed, unusual character states that seem to be putative synapomorphies of this section. Its members were previously placed in $S$. subg. Duvaua sect. Pseudoduvaua, except for $S$. microphylla, a species recognized as belonging to $S$. subg. Duvaua sect. Duvaua. Delimitation issues have been neglected in species of this section, since most studies have focused on taxa belonging to $S$. subg. Duvaua sect. Duvaua. The present morphological study reveals a significant number of taxonomic circumscription problems, especially between $S$. andina and S. myrtifolia. Detailed morphological analyses of numerous exsiccatae reveals four new species which are described herein. We provide identification key, descriptions, synonyms, nomenclatural types, including three designations of lectotypes, two new combinations, illustrations, distribution maps, and comments on nomenclatural, distribution and preliminary conservation assessments of all species. The taxonomic novelties here presented in Schinus sect. Myrtifolia contribute to disentangle the complexity of the group and its misidentified species, taking into account the morphological traits of a virtually complete sampling and a careful nomenclatural revision. In this way we hope to have evaluated all range of morphological variation, especially within $S$. andina and $S$. myrtifolia, which has been overlooked until now. In summary the phylogenetic study of Schinus provided here including a much broader sampling of all lineages in the genus, offers opportunities for further 
taxonomic, evolutionary and biogeographical studies in Schinus. The biogeographical investigations associated with the diversification of Schinus and closely related taxa from Anacardiaceae seem to be promising and may contribute to new insights into the history of southern South American biota. 
Individual phylogenetic trees resulting from Bayesian inference of Schinus

Combined phylogenetic trees resulting from Maximum Likelihood and Maximum Parsimony using 11 plastid and nuclear datasets of Schinus and closely related genera from Anacardiaceae 
(A)

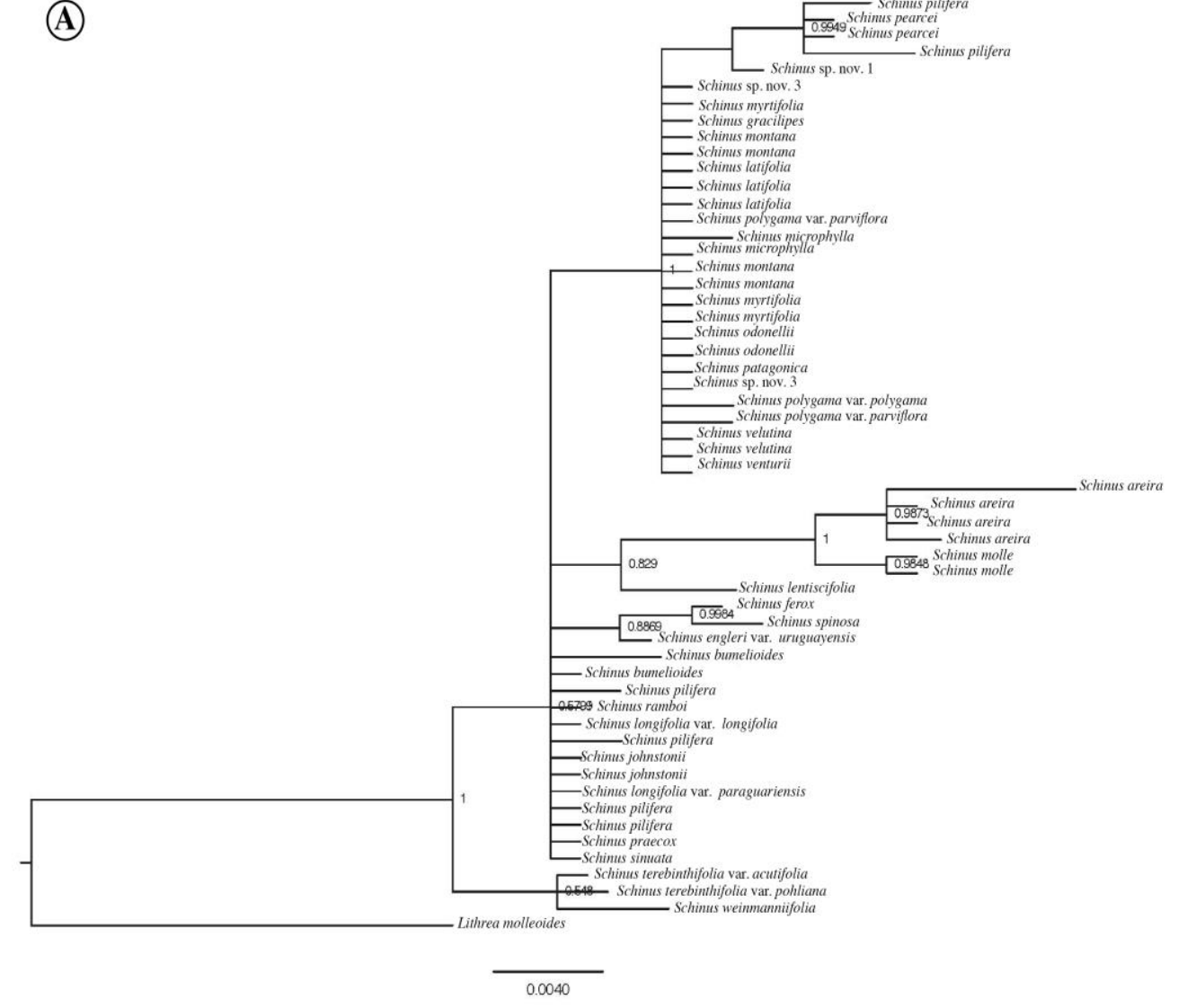

(B)

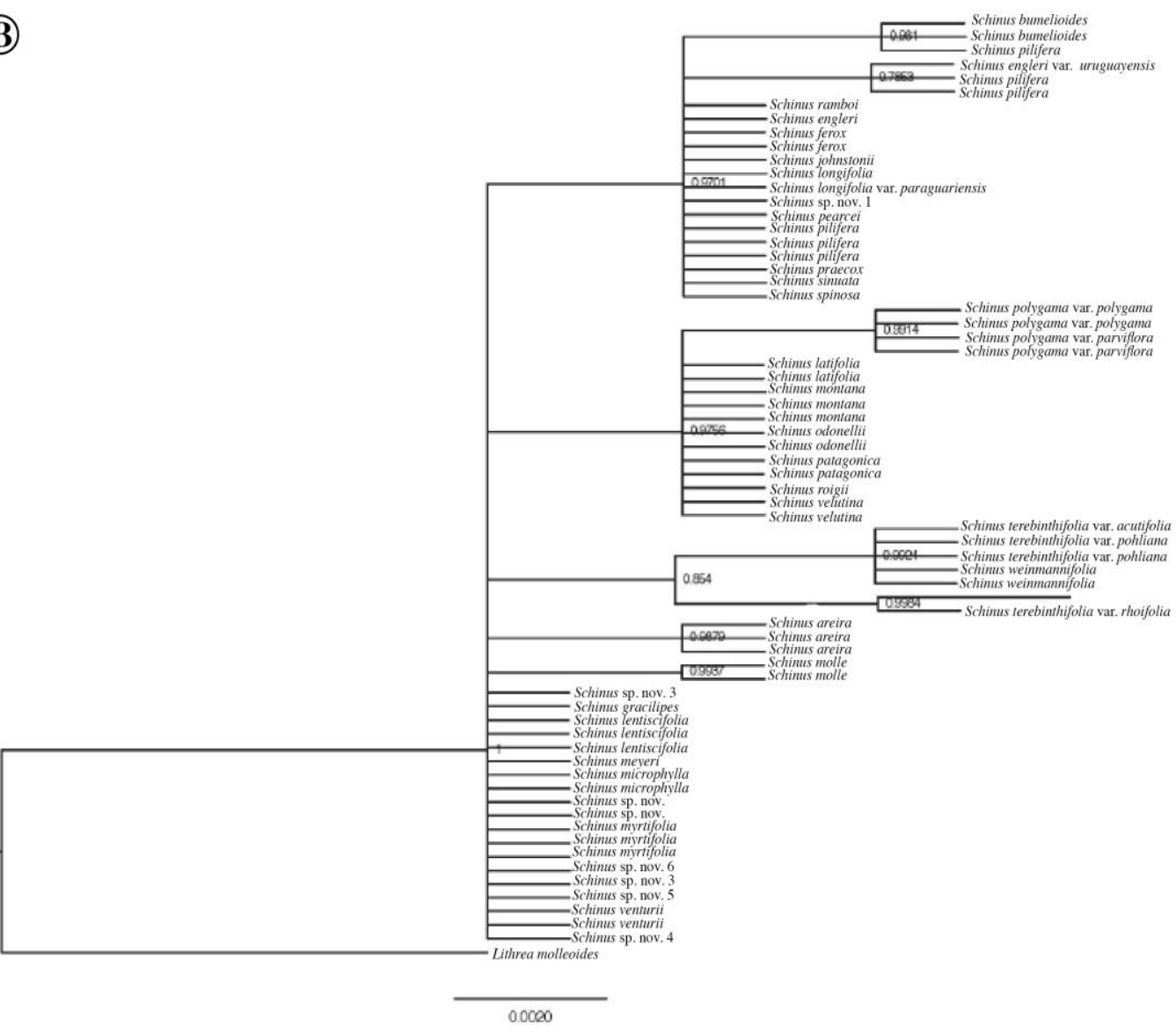

Fig. 1. Phylogeny of Schinus. A: Bayesian half-compatible consensus tree using 4620 nuclear marker. B: Bayesian half-compatible consensus tree using 20790 nuclear marker. Posterior probability values are associated with branches. 


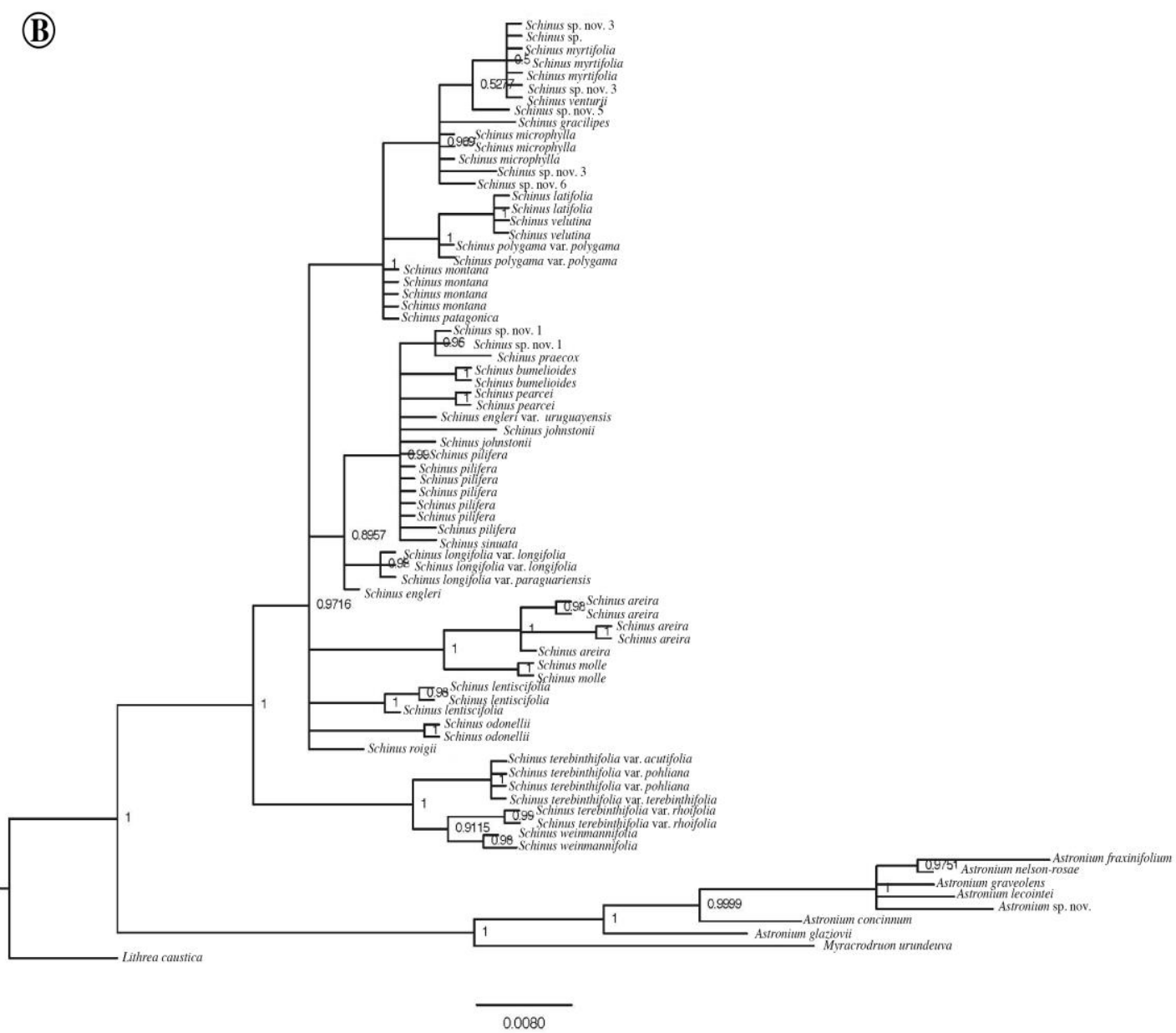

Fig. 2. Phylogeny of Schinus. A: Bayesian half-compatible consensus tree using 26580 nuclear marker. B: Bayesian half-compatible consensus tree using 44760 nuclear marker. Posterior probability values are associated with branches. 


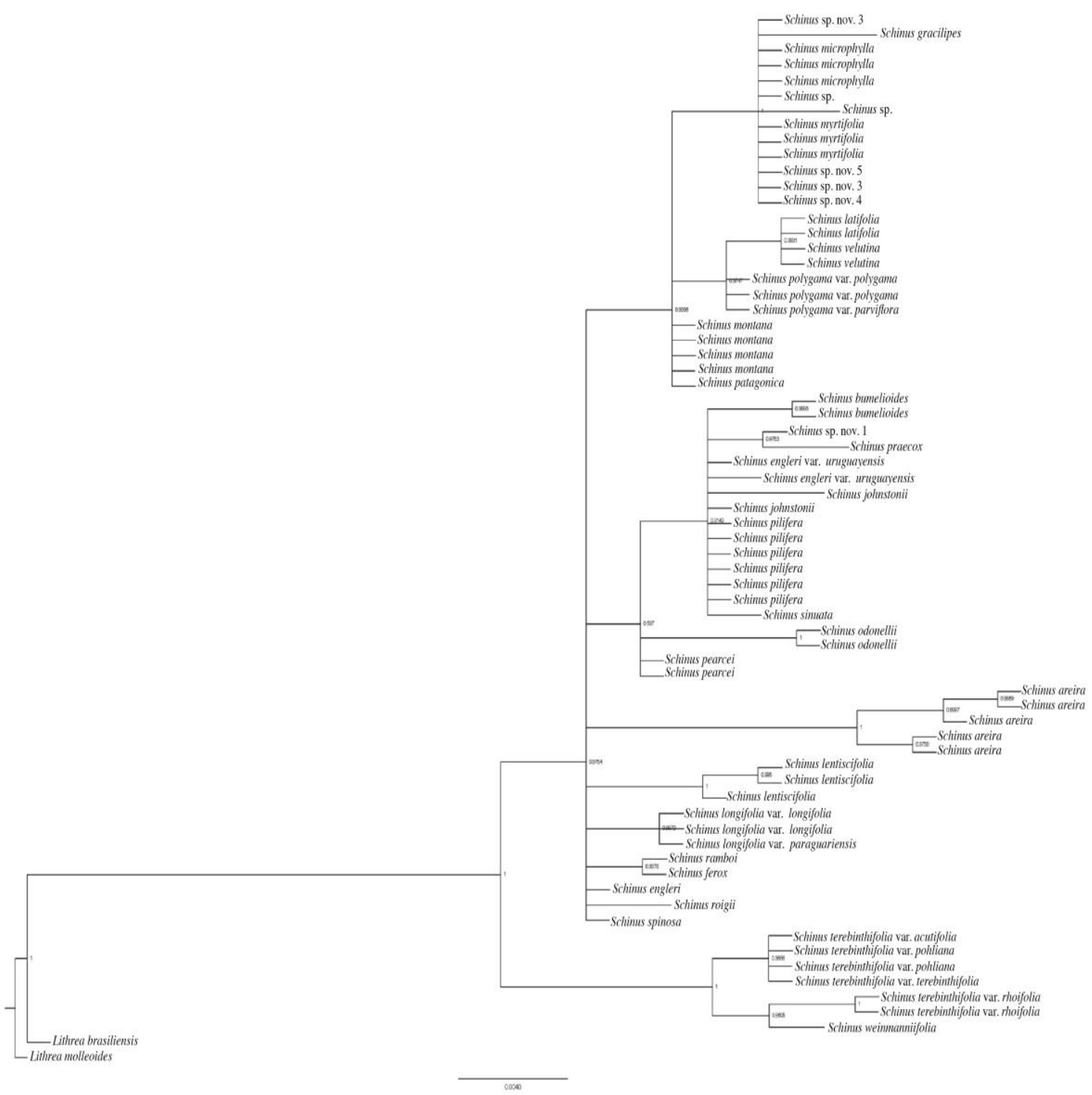

Fig. 3. Bayesian half-compatible consensus tree of Schinus using 47760 nuclear marker. Posterior probability values are associated with branches. 

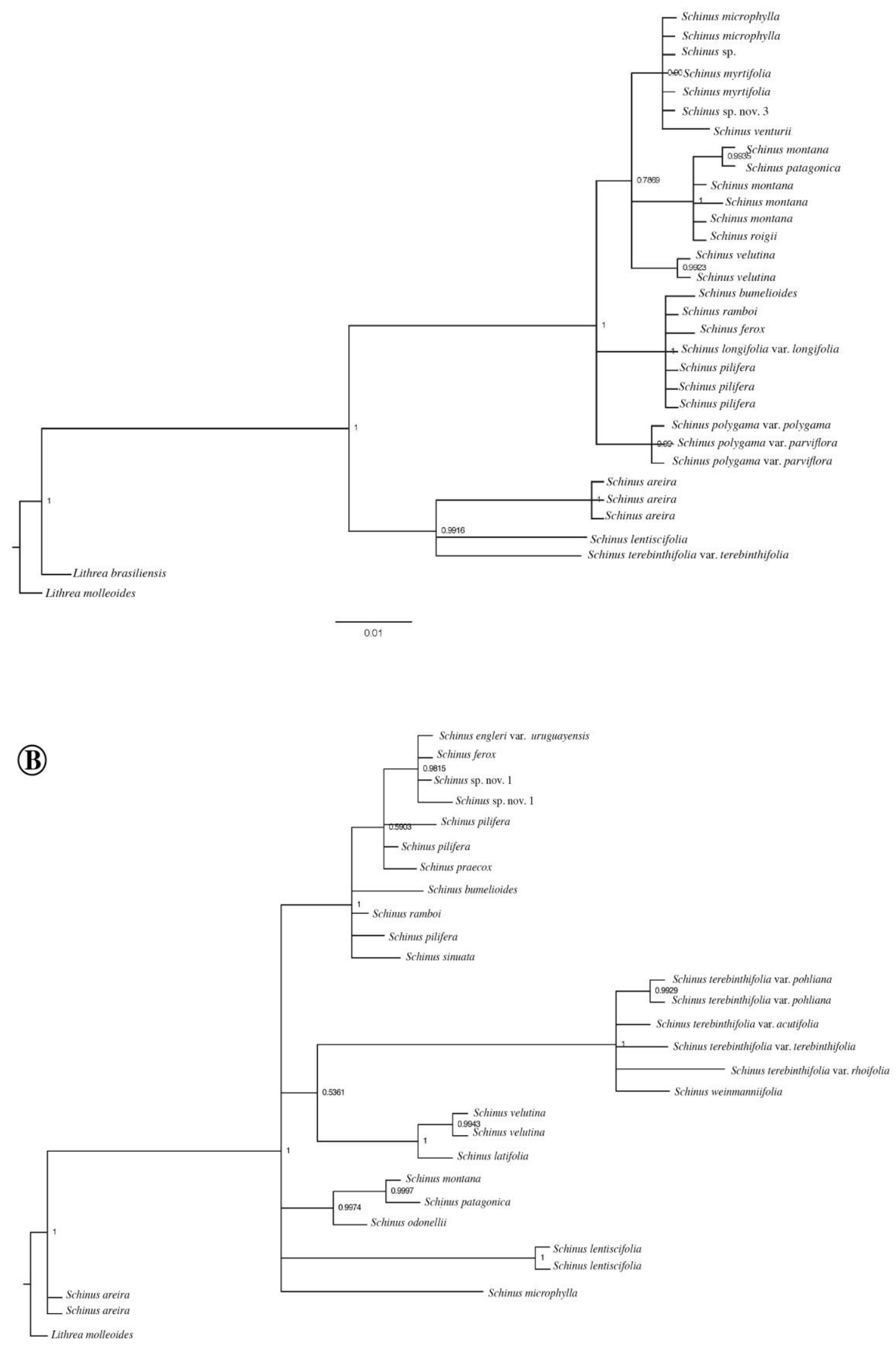

Fig. 4. Phylogeny of Schinus. A: Bayesian half-compatible consensus tree using 48790 nuclear marker. B: Bayesian half-compatible consensus tree using 63169 nuclear marker. Probability values are associated with branches. 
(A)
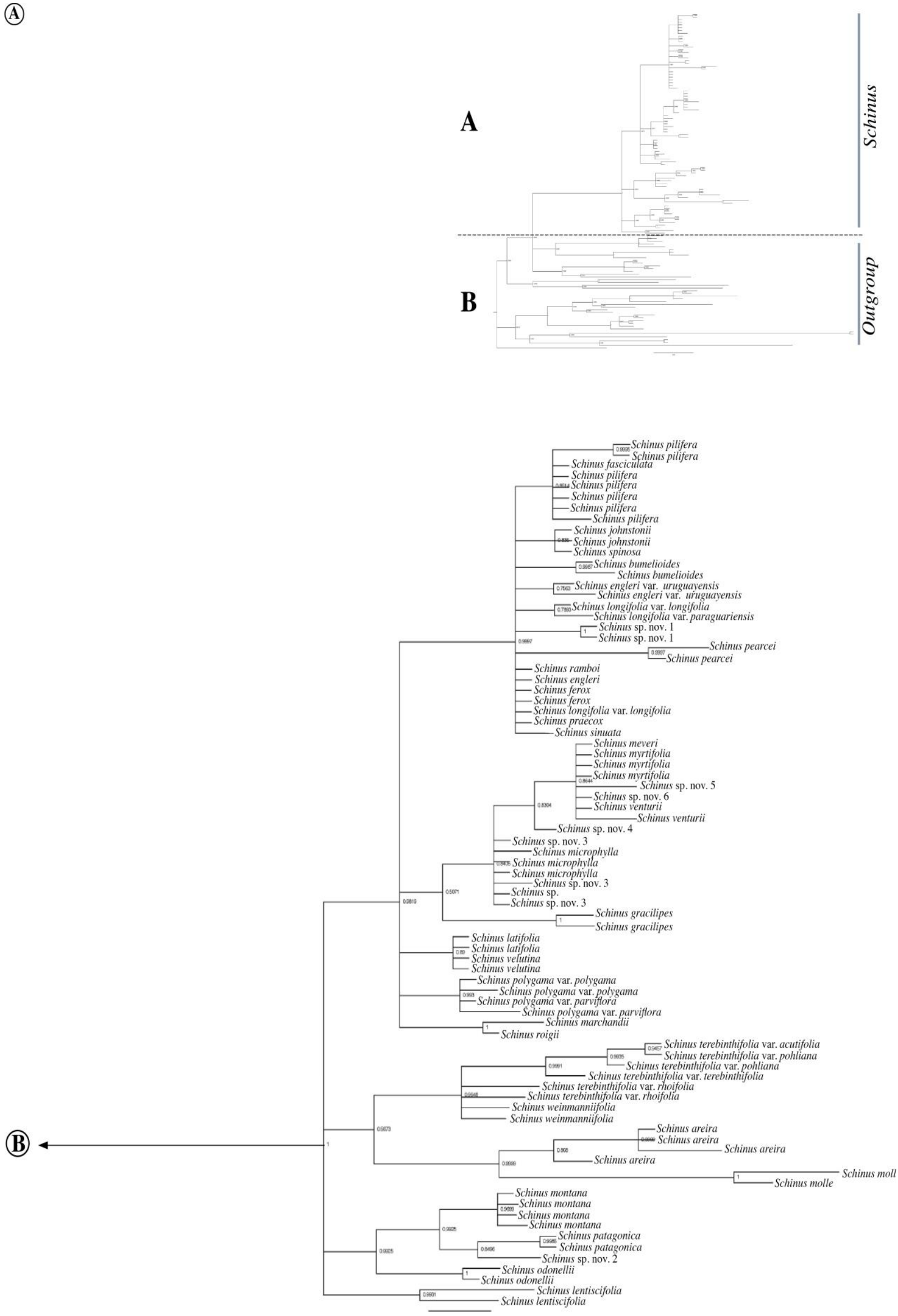

Fig. 5A-B. Phylogeny of Schinus and closely related genera from Anacardiaceae (at the top right). A. Bayesian half-compatible consensus tree of Schinus using ETS nuclear marker. Posterior probability values are associated with branches. 

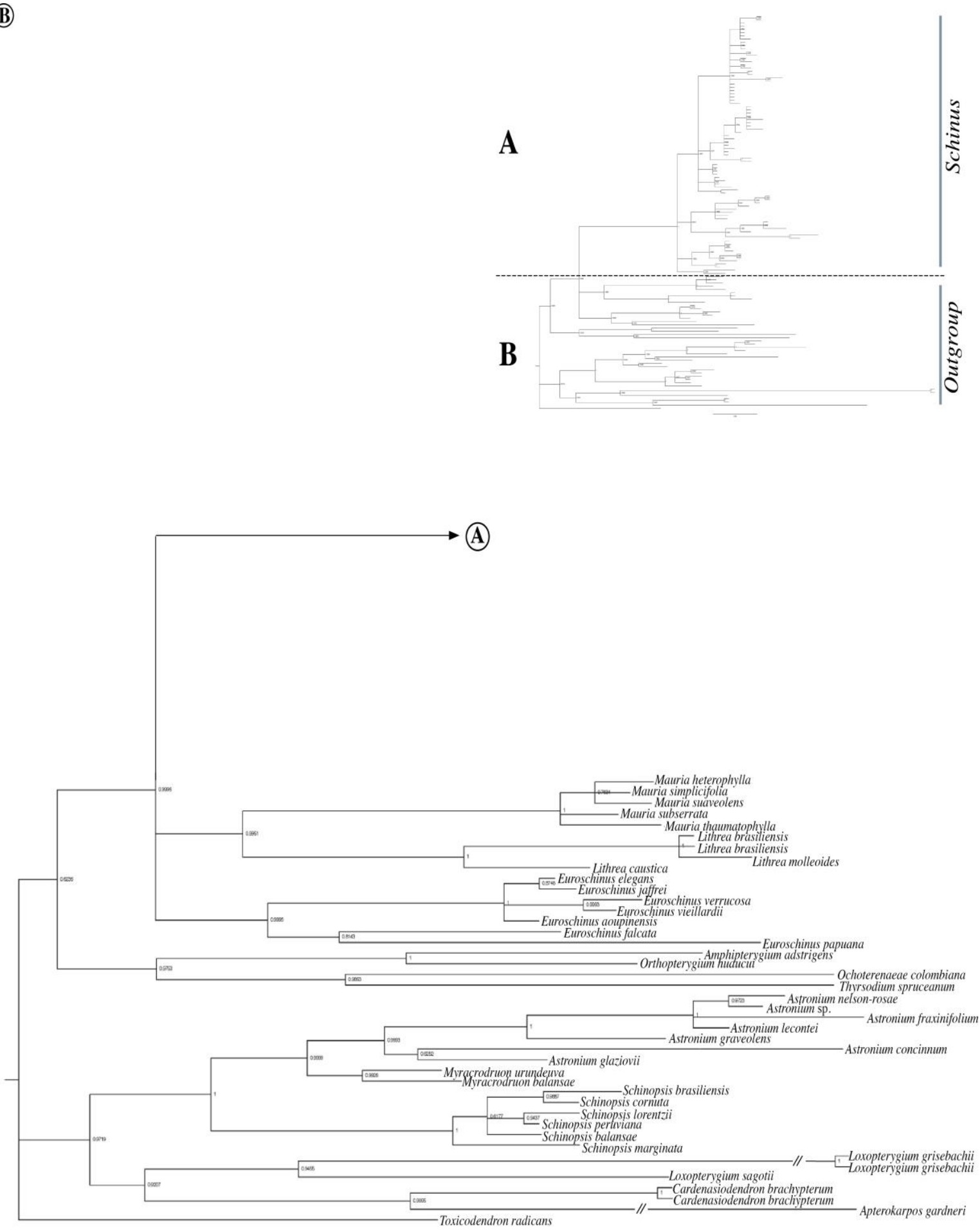

Fig. 5A-B. Phylogeny of Schinus and closely related genera from Anacardiaceae (at the top right). B: Bayesian half-compatible consensus tree of Anacardiaceae genera closely related to Schinus using ETS nuclear marker. Posterior probability values are associated with branches. Two bars indicate that the branch is longer than represented. 


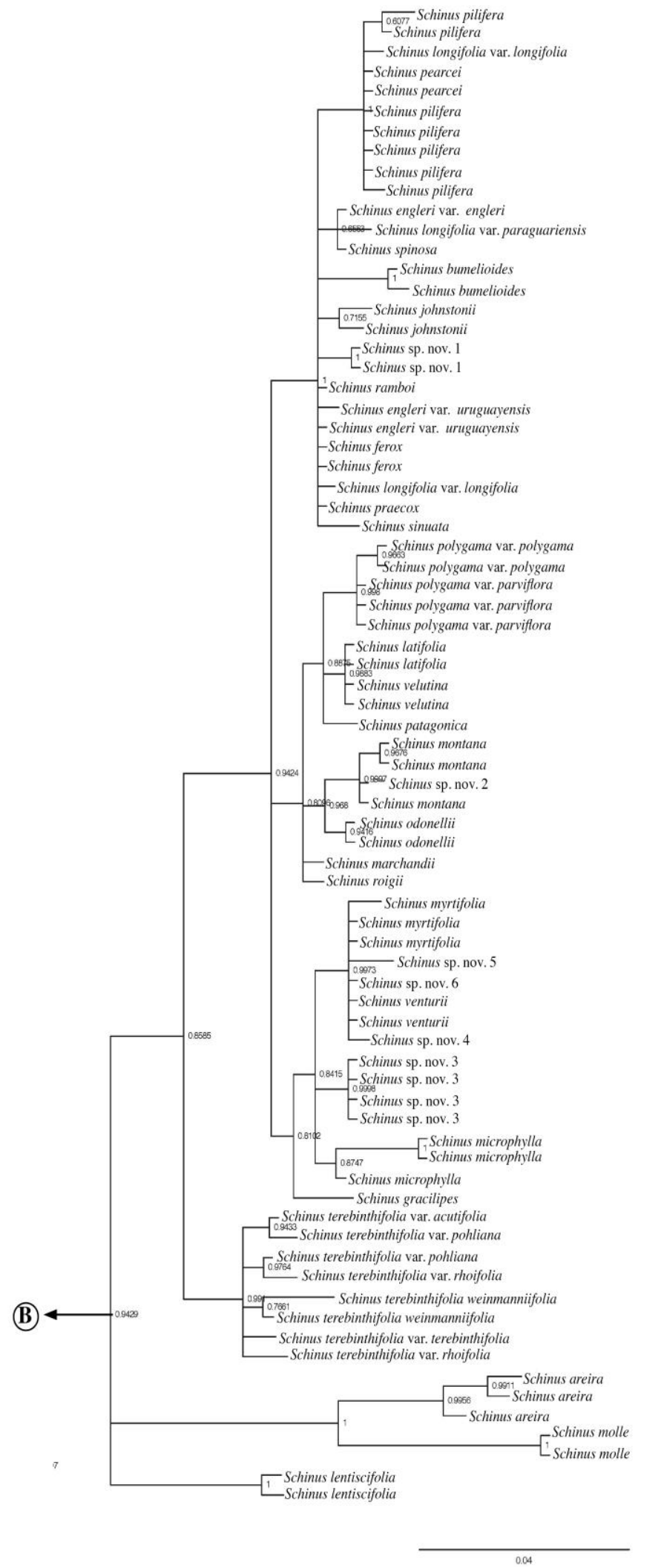

A

B

Fig. 6A-B. Phylogeny of Schinus and closely related genera from Anacardiaceae (at the top right). A: Bayesian half-compatible consensus tree of Schinus using ITS nuclear marker. Posterior probability values are associated with branches. 

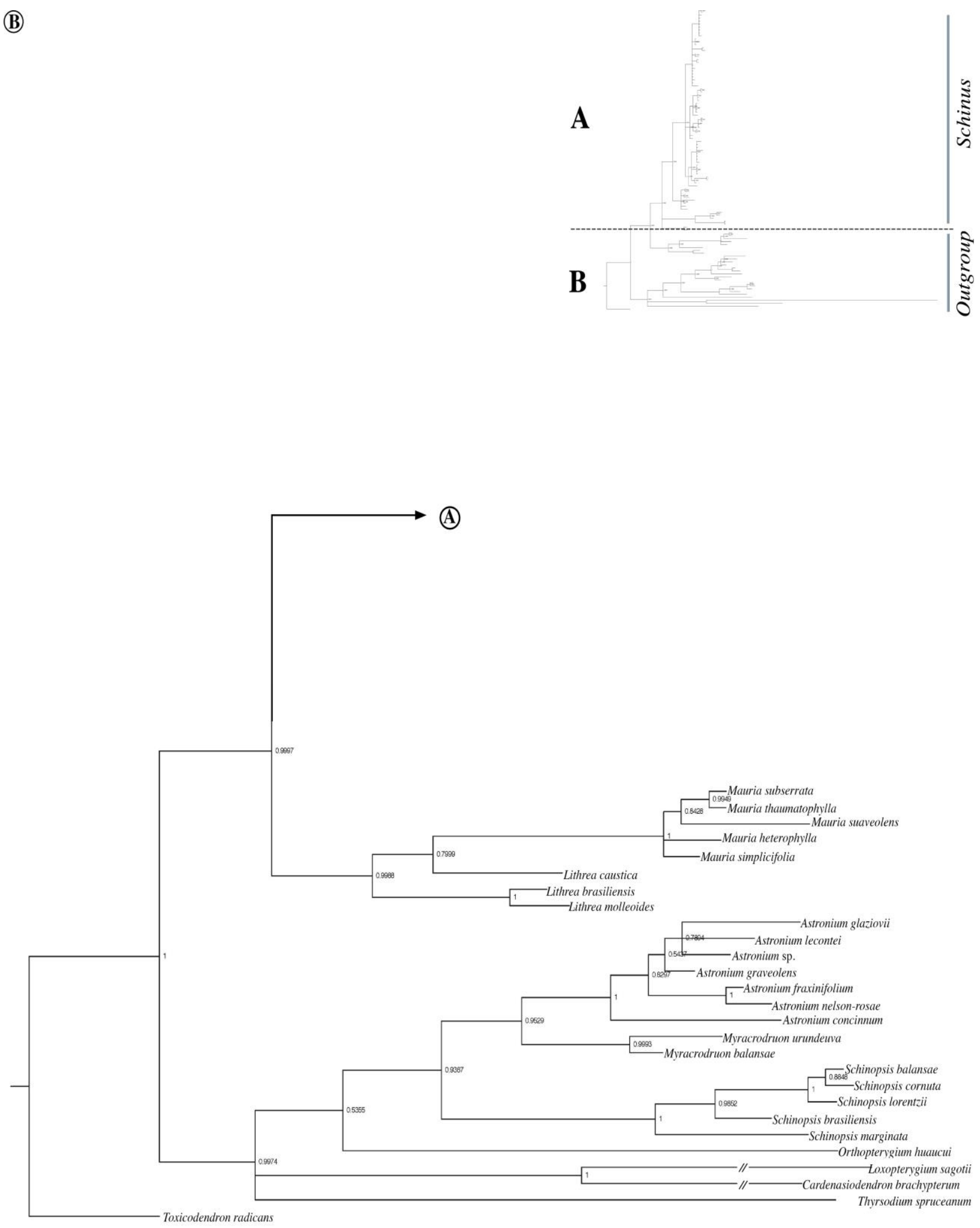

Fig. 6A-B. Phylogeny of Schinus and closely related genera from Anacardiaceae (at the top right). B: Bayesian half-compatible consensus tree of Anacardiaceae genera closely related to Schinus using ITS nuclear marker. Posterior probability values are associated with branches. Two bars indicate that the branch is longer than represented. 

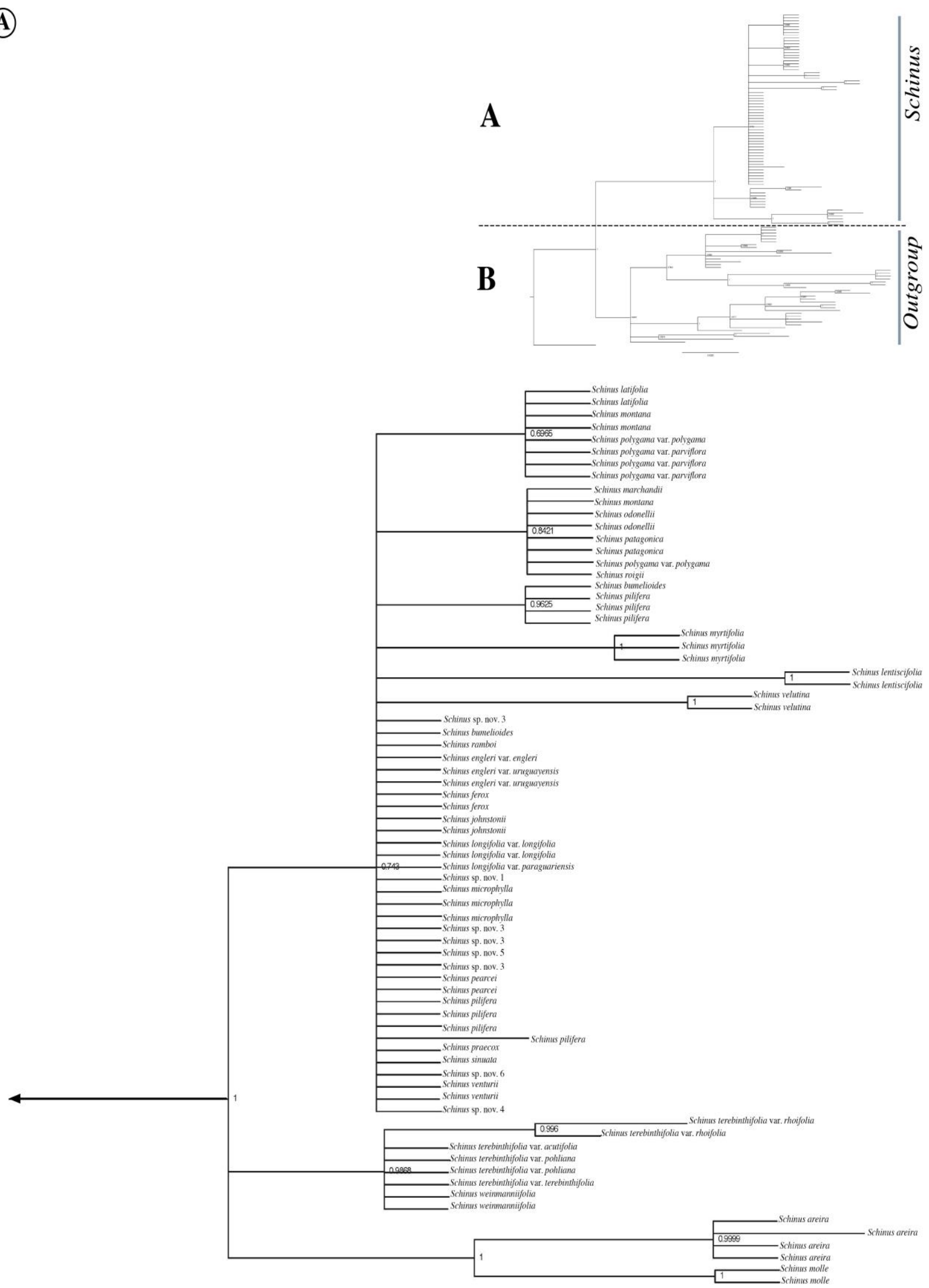

0.0020

Fig. 7A-B. Phylogeny of Schinus and closely related genera from Anacardiaceae (at the top right). A: Bayesian half-compatible consensus tree of Schinus using $t r n L-F$ plastid marker. Posterior probability values are associated with branches. 
(B)
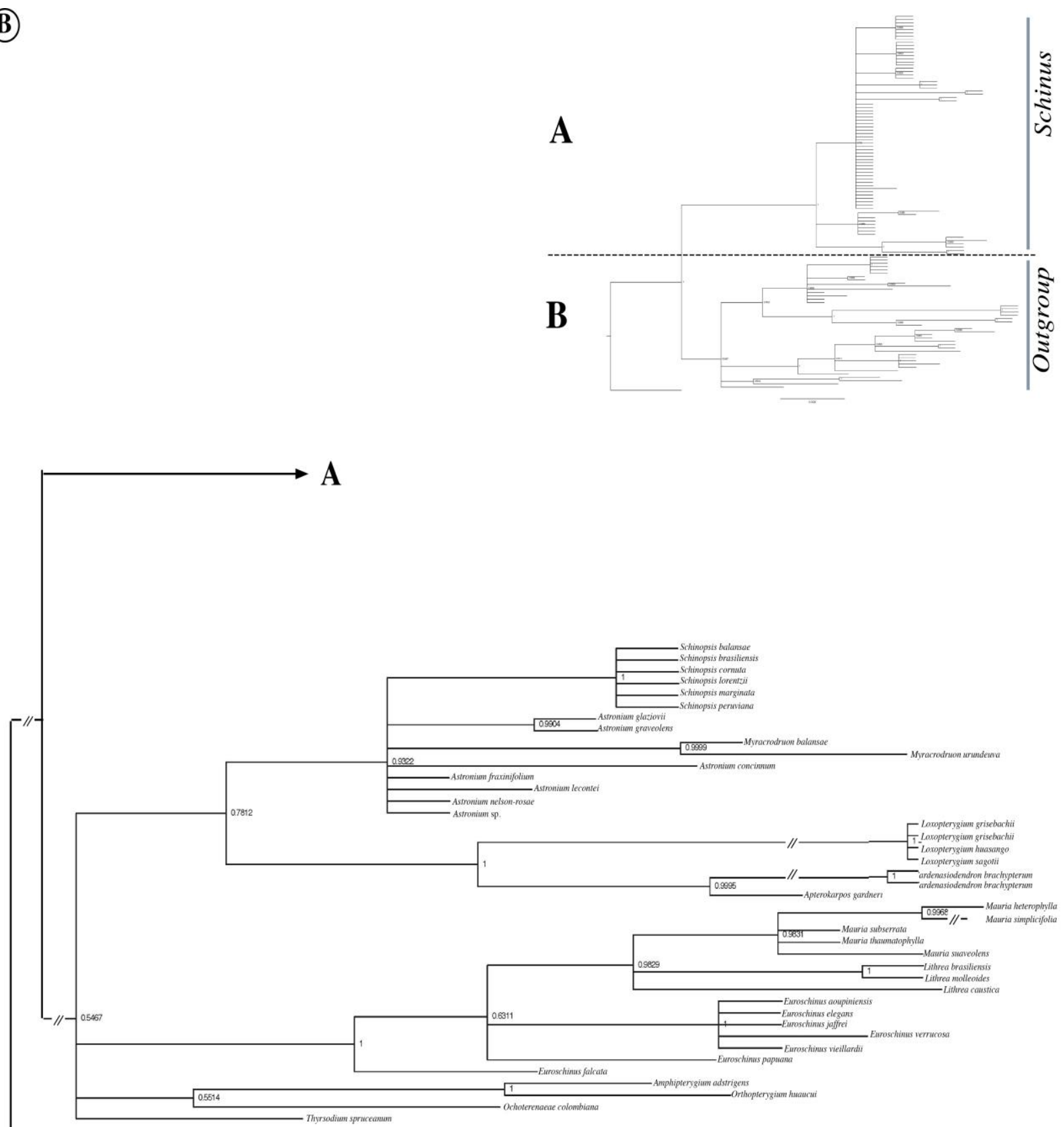

Toxodendron radicuns

Fig. 7A-B. Phylogeny of Schinus and closely related genera from Anacardiaceae (at the top right). B: Bayesian half-compatible consensus tree of Anacardiaceae genera closely related to Schinus using trnL-F plastid marker. Posterior probability values are associated with branches. Two bars indicate that the branch is longer than represented. 
(A)

A
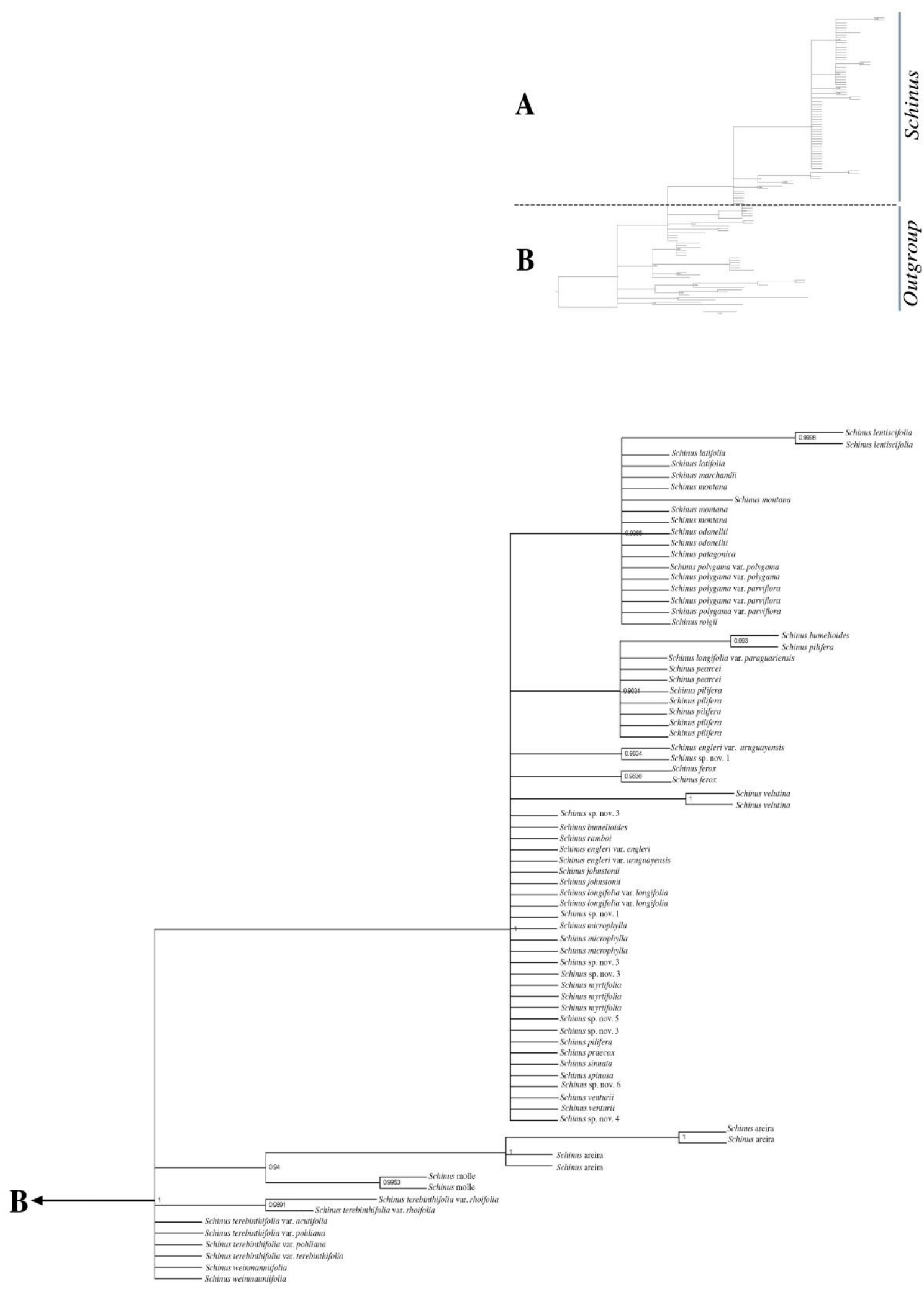

Fig. 8A-B. Phylogeny of Schinus and closely related genera from Anacardiaceae (at the top right). A: Bayesian half-compatible consensus tree of Schinus using rps-16 plastid marker. Posterior probability values are associated with branches. 
(B)

A

B

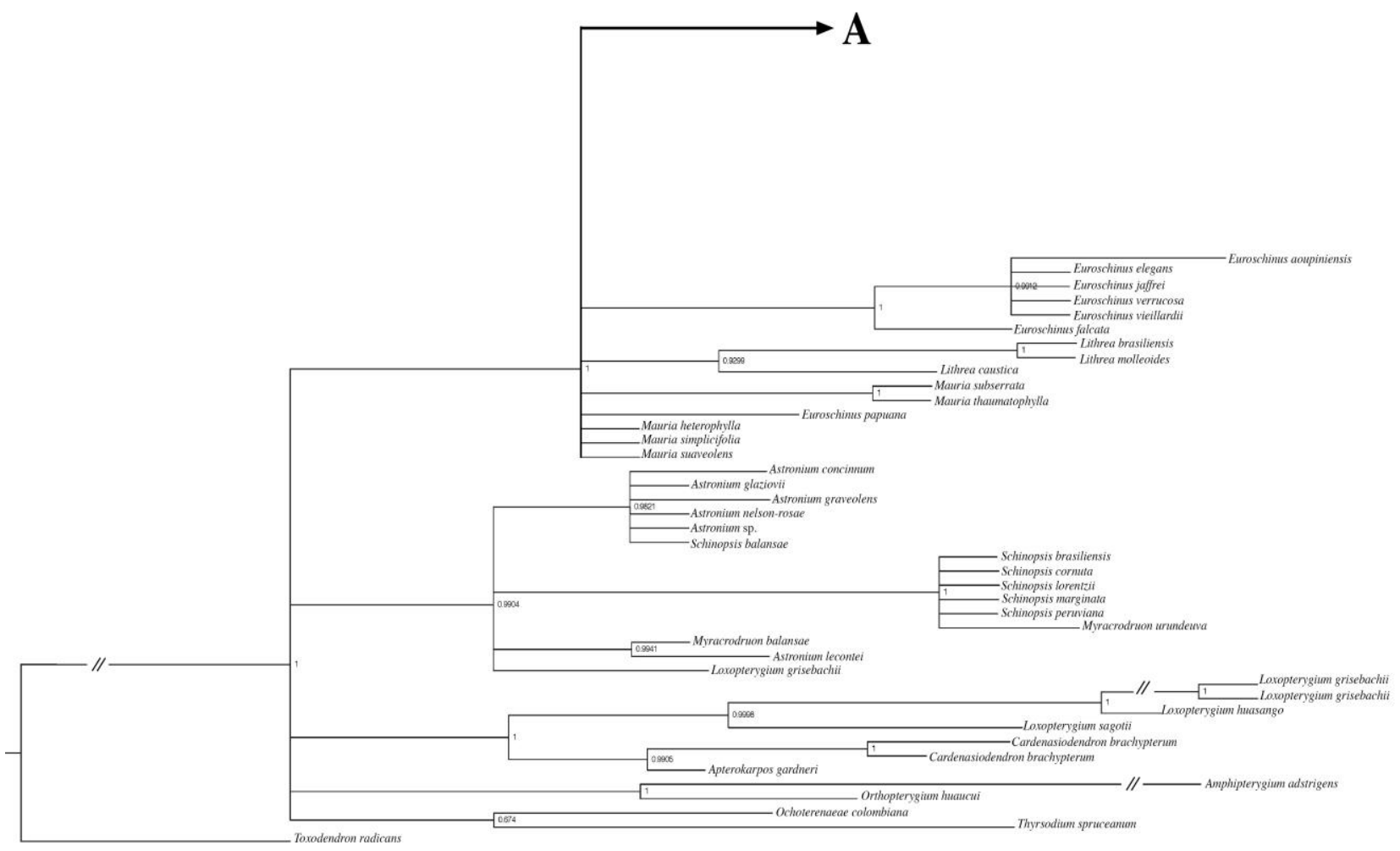

Fig. 8A-B. Phylogeny of Schinus and closely related genera from Anacardiaceae. B: Bayesian half-compatible consensus tree of Anacardiaceae genera closely related to Schinus using rps-16 plastid marker. Posterior probability values are associated with branches. Two bars indicate that the branch is longer than represented. 
(A)
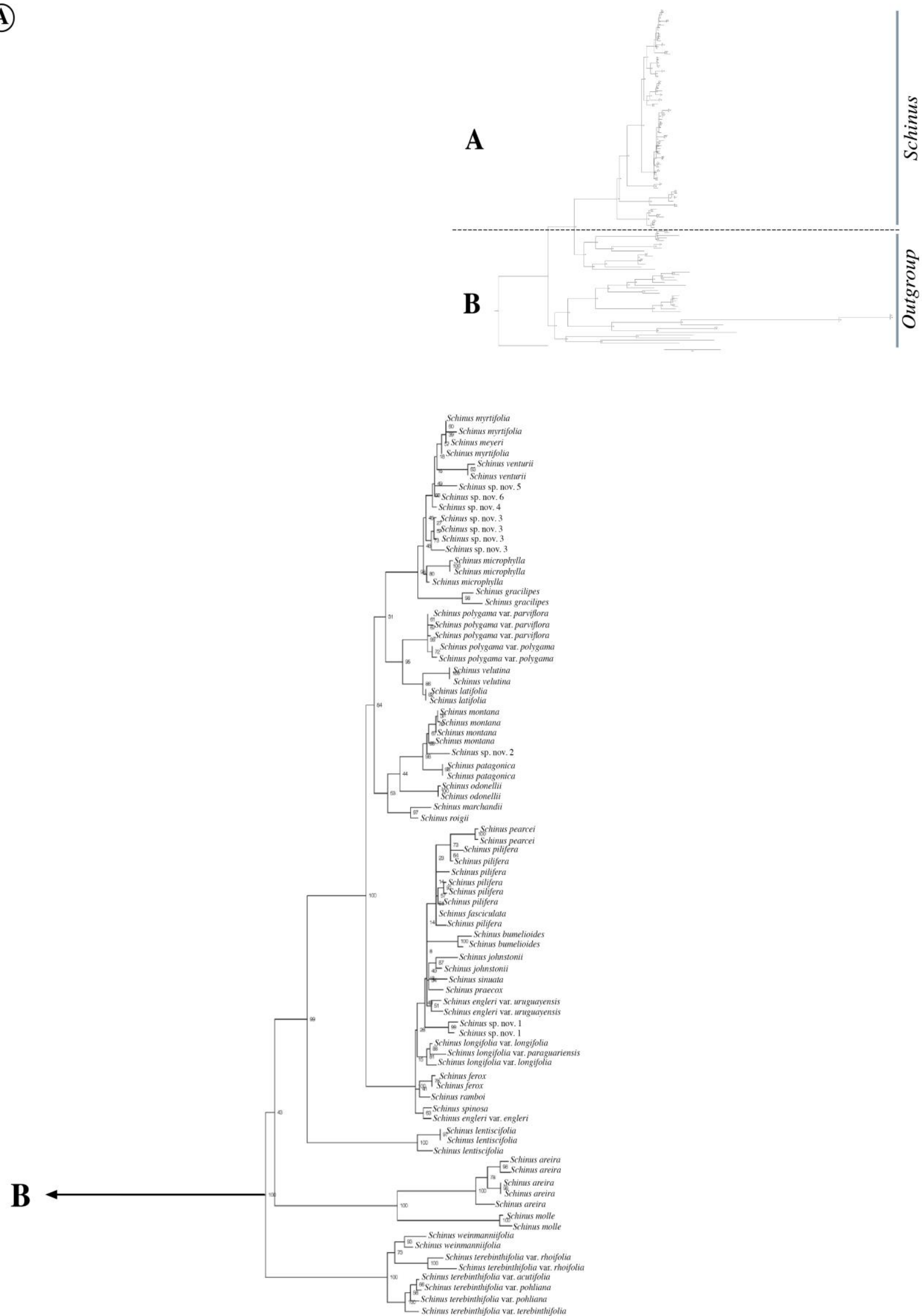

Fig. 9. Phylogeny of Schinus and closely related genera from Anacardiaceae (at the top right). A: Phylogeny of Schinus resulting from maximum likelihood analysis using 11 nuclear and plastid dataset $(4620,20790,26580$, $44760,47760,48790,63160$, ETS, ITS, rps-16, trnL-F). Posterior probability values are associated with branches. 
(B)
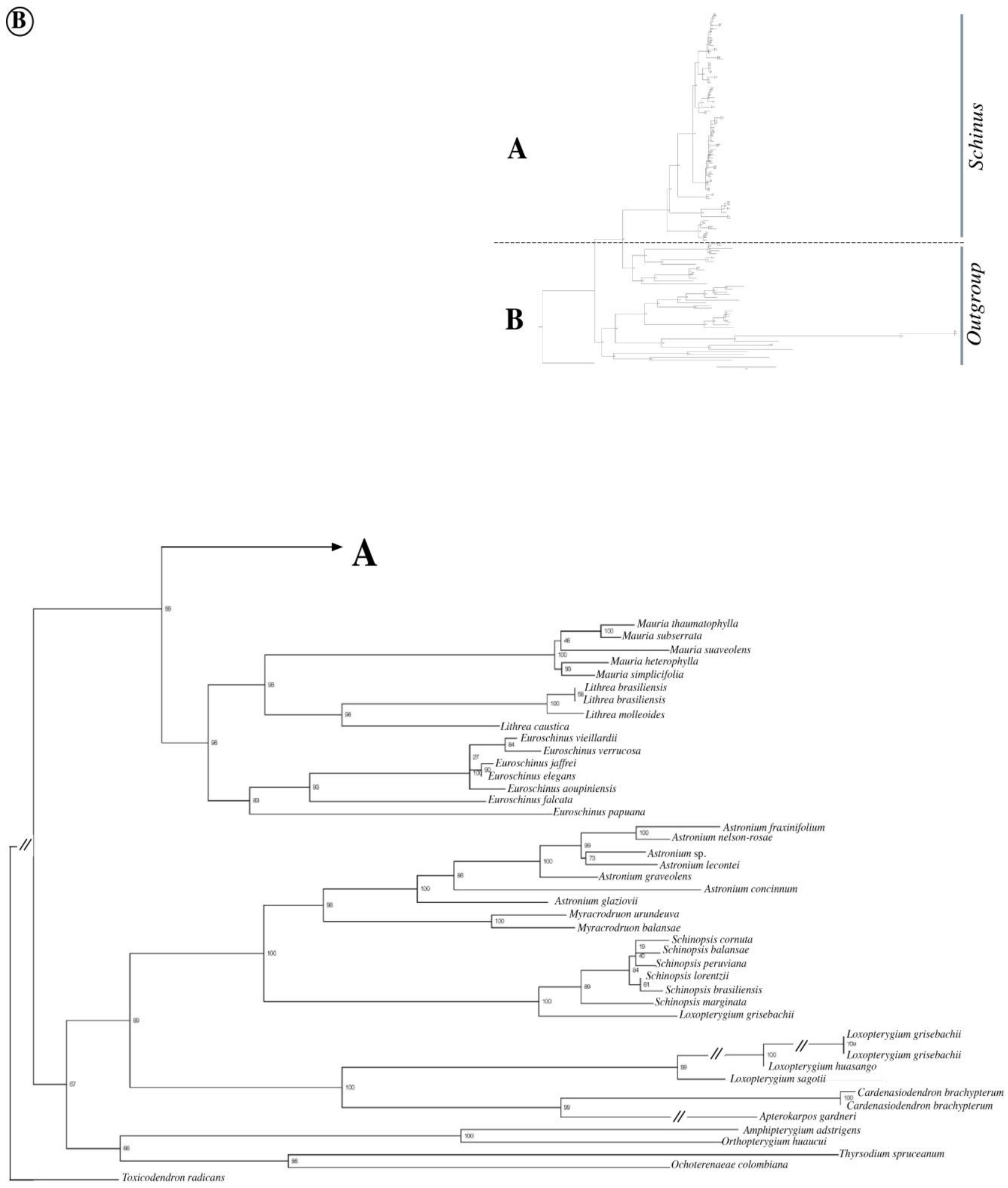

Fig. 9. Phylogeny of Schinus and closely related genera from Anacardiaceae (at the top right). B: Anacardiaceae genera closely related to Schinus resulting from maximum likelihood analysis using 11 nuclear and plastid dataset (4620, 20790, 26580, 44760, 47760, 48790, 63160, ETS, ITS, rps-16, trnL-F). Posterior probability values are associated with branches. Two bars indicate that the branch is longer than represented. 


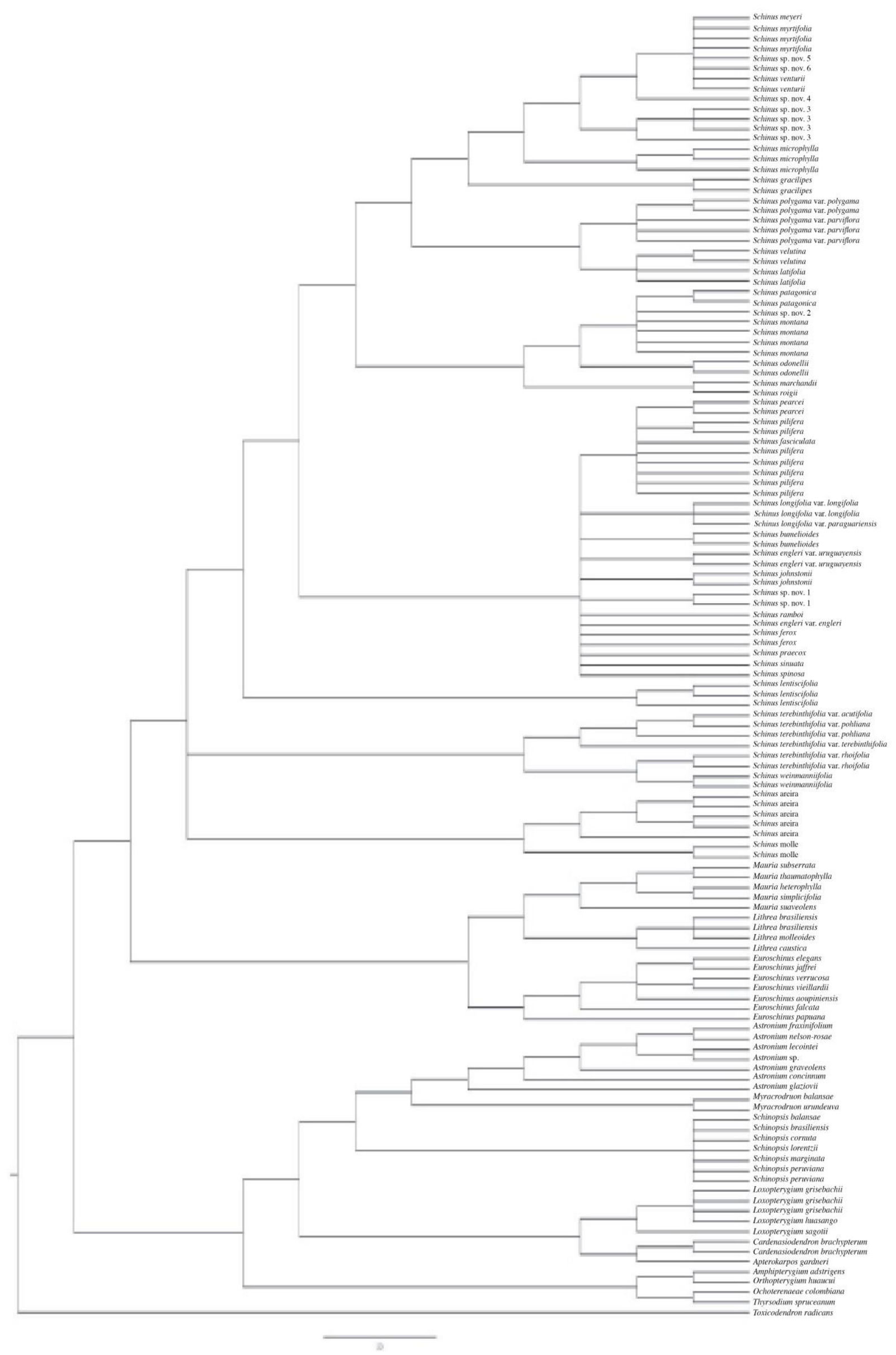

Fig. 10. Phylogeny of Schinus and closely related genera from Anacardiaceae resulting from maximum parsimony analysis using 11 nuclear and plastid dataset (4620, 20790, 26580, 44760, 47760, 48790, 63160, ETS, ITS, rps-16, trnL-F). 